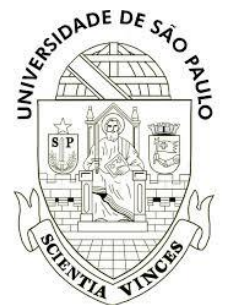

UNIVERSIDADE DE SÃO PAULO

FACULDADE DE FILOSOFIA, LETRAS E CIÊNCIAS HUMANAS DEPARTAMENTO DE HISTÓRIA PROGRAMA DE PÓS-GRADUAÇÃO EM HISTÓRIA SOCIAL

GIUSEPPE RONCALLI PONCE LEON DE OLIVEIRA

CORRESPONDÊNCIA DE LUÍS DA CÂMARA CASCUDO: Arquivos da Criação e Redes de Sociabilidade Intelectual 


\title{
CORRESPONDÊNCIA DE LUÍS DA CÂMARA CASCUDO: Arquivos da Criação e Redes de Sociabilidade Intelectual
}

\begin{abstract}
Tese apresentada ao Programa de Pós-Graduação em História Social da Faculdade de Filosofia, Letras e Ciências Humanas da Universidade de São Paulo como requisito necessário para a obtenção do título de Doutor em História.
\end{abstract}

Orientador: prof. Dr. Marcos Silva. 


\section{CORRESPONDÊNCIA DE LUÍS DA CÂMARA CASCUDO:}

\section{Arquivos da Criação e Redes de Sociabilidade Intelectual}

Tese apresentada ao Programa de Pós-Graduação em História Social da Faculdade de Filosofia, Letras e Ciências Humanas da Universidade de São Paulo como requisito necessário para a obtenção do título de Doutor em História.

Orientador: prof. Dr. Marcos Silva.

Data da Aprovação

SÃO PAULO

2016 
Autorizo a reprodução e divulgação total ou parcial deste trabalho, por qualquer meio convencional ou eletrônico, para fins de estudo e pesquisa, desde que citada a fonte.

Catalogação na Publicação

Serviço de Biblioteca e Documentação

Faculdade de Filosofia, Letras e Ciências Humanas da Universidade de São Paulo

$048 \mathrm{C}$

Oliveira, Giuseppe Roncalli Ponce Leon de Oliveira CORRESPONDÊNCIA DE LUÍS DA CÂMARA CASCUDO: Arquivos da Criação e Redes de Sociabilidade Intelectual / Giuseppe Roncalli Ponce Leon de Oliveira Oliveira ; orientador Marcos Antônio da Silva Silva. - São Paulo, 2016. $286 \mathrm{f}$.

Tese (Doutorado)- Faculdade de Filosofia, Letras e Ciências Humanas da Universidade de São Paulo. Departamento de História. Área de concentração: História Social.

1. Luís da Câmara Cascudo. 2. Correspondência. 3. Arquivos da Criação. 4. Redes de Sociabilidade Intelectual. I. Silva, Marcos Antônio da Silva, orient. II. Título. 


\section{RESUMO}

A presente tese propõe um estudo pormenorizado da correspondência de Luís da Câmara Cascudo com Mário de Andrade, Joaquim Inojosa, Gilberto Freyre e José Américo de Almeida (de 1922 a 1984), tendo como objetivo ampliar o debate historiográfico travado em torno da tentativa de restringir a produção intelectual de Cascudo à sua filiação ao Movimento Modernista ou ao Movimento Regionalista Tradicionalista do Nordeste. Para tanto, trataremos do debate suscitado pela epistolografia cascudiana, com ênfase na correspondência ativa de Cascudo editada e publicada antes e depois da publicação do volume Cartas de Mário de Andrade a Luís da Câmara Cascudo (2000), organizado por Veríssimo de Melo. Por intermédio das cartas enviadas por Monteiro Lobato, Rocha Pombo, Pedro de Orleans e Bragança \& Guilherme Auler, disponíveis no acervo do Ludovicus - Instituto Câmara Cascudo, buscamos demonstrar que para além do debate sobre o Modernismo no campo da crítica literária, houve durante o período de correspondência com Mário de Andrade a aproximação e o interesse de Câmara Cascudo em relação ao campo historiográfico, como a associação ao pensamento conservador monárquico. Empenhamo-nos em reconstituir as redes de sociabilidades intelectuais estabelecidas através da correspondência, tomando-as como arquivos da criação das obras e ideias sobre os movimentos anteriormente referidos. Buscamos demonstrar de maneira circunstanciada as complexas relações existentes na historiografia do regionalismo e modernismo no contexto da modernização da região Nordeste do Brasil, analisando as atitudes dos atores envolvidos no processo, assim como as contradições que ele implica.

Palavras-Chaves: Luís da Câmara Cascudo, correspondência, arquivos da criação, redes-de-sociabilidade intelectual, Modernismo, Regionalismo-TradicionalistaNordestino. 


\begin{abstract}
This thesis proposes a detailed study of the correspondence written by Luís da Câmara Cascudo along with Mário de Andrade, Joaquim Inojosa, Gilberto Freyre and José Américo de Almeida (1922 - 1984). The objective is to widen the historiographical discussion around the attempt to restrict Cascudo's intellectual production and his affiliation to the Modernist Movement or to the Traditionalist Regionalist Movement from the Northeast. For this purpose, we will approach the debate caused by Cascudo's epistolography giving emphasis to his active correspondence which was edited and published before and right after the publication of the volume Cartas de Mário de Andrade a Luís da Câmara Cascudo (2000), organized by Veríssimo de Melo. Based on letters written by Monteiro Lobato, Rocha Pombo, Pedro de Orleans, and Bragança \& Guilherme Auler, available at the collection of Ludovicus - Instituto Câmara Cascudo, we demonstrate that Cascudo goes beyond the debate on Modernism, on the field of literary criticism. In fact, during the period he and Mário de Andrade were corresponding, Cascudo showed interest and approached the field of historiography, relating to the monarchic conservative thought. We put effort to reconstruct the network of intellectual sociability established through the correspondence that was used as files for the creation of his work and ideas about the movements previously mentioned. We demonstrate in details the complex relations that exist in the historiography of the regionalism and modernism, in the context of the modernization in the Northeast Part of Brazil, analyzing the attitude of those who are involved in the process and the contradictions of the process itself.
\end{abstract}

Key words: Luís da Câmara Cascudo, correspondence, files of creation, network of intellectual sociability, Modernism, Northeastern Traditionalist Regionalism. 


\section{RESUMEN}

La presente tesis propone un estudio detallado de la correspondencia de Luís da Câmara Cascudo con Mário de Andrade, Joaquim Inojosa, Gilberto Freyre y José Américo de Almeida (de 1922 a 1984), teniendo como objetivo ampliar el debate historiográfico desarrollado en el intento de restringir la producción intelectual de Cascudo a su filiación al Movimiento Modernista o al Movimiento Regionalista Tradicionalista del Noreste. Para eso, trataremos el debate fomentado por la epistolografía cascudiana, enfatizando en la correspondencia activa de Cascudo editada y publicada antes y depués de la publicación del volumen Cartas de Mário de Andrade a Luís da Câmara Cascudo (2000), organizado por Veríssimo de Melo. Por intermedio de las cartas enviadas por Monteiro Lobato, Rocha Pombo, Pedro de Orleans y Bragança \& Guilherme Auler, disponibles en la colección de Ludovicus - Instituto Câmara Cascudo, buscamos demostrar que además del debate sobre el Modernismo en el campo de crítica literária, hubo durante el período de correspondencia con Mário de Andrade, una aproximación e interés de Câmara Cascudo en relación al campo historiográfico, como la asociación al pensamiento conservador monárquico. Nos empeñamos en reconstruir las redes de sociabilidad intelectual establecidas através de la correspondencia, tomándolas como archivos de creación de las obras e ideas sobre los movimentos anteriormente referidos. Buscamos demostrar de manera circunstanciada las relaciones complejas existentes en la historiografía del regionalismo y modernismo en el contexto de la modernización de la región Noreste de Brasil, analizando las actitudes de los actores comprometidos en el proceso, así como las contradicciones implicadas.

Palavras Llaves: Luís da Câmara Cascudo, correspondencia, archivos de creación, redes de sociabilidad intelectual, Modernismo, Regionalismo-TradicionalistaNordestino (noreste). 


\section{RÉSUMÉ}

Cette thèse propose une étude détaillée des correspondances que Luís da Câmara Cascudo a entretenues avec Mário de Andrade, Joaquim Inojosa, Gilberto Freyre et José Américo de Almeida dans la période comprise entre 1922 et 1984, ayant pour but d'élargir le débat historiographique concernant la tentative de restreindre la production intellectuelle de Cascudo à sa filiation au Mouvement Moderniste ou au Mouvement Régionaliste Traditionnaliste du Nord-Est du Brésil. Nous aborderons, dans cette intention, le débat suscité par l'épistolographie de Cascudo, et notamment par sa correspondance active éditée et publiée avant et après la parution du volume Cartas de Mário de Andrade a Luís da Câmara Cascudo (2000), organisé par Veríssimo de Melo. En nous appuyant sur les lettres envoyées à Cascudo par Monteiro Lobato, Rocha Pombo, Pedro de Orleans e Bragança et Guilherme Auler, toutes appartenant au fonds du Ludovicus - Instituto Câmara Cascudo, nous cherchons à montrer que par-delà le débat dont le Modernisme a fait l'objet dans le domaine de la critique littéraire, la correspondance que Cascudo a entretenue avec Mário de Andrade est contemporaine de son rapprochement du champ historiographique, illustré par son ralliement à la pensée conservatrice monarchique. Nous nous sommes attaché à reconstituer les réseaux des socialibilités intellectuelles fondés sur la correspondance, en les considérant comme des archives de la création des œuvres et des idées relatives aux deux mouvements mentionnés précédemment. Nous nous sommes également efforcé de montrer en détail les relations complexes touchant l'historiographie du régionalisme et du modernisme dans le contexte de la modernisation de la région Nord-Est du Brésil, en soumettant à l'analyse les attitudes des acteurs engagés dans ce processus, de même que les contradictions qui en sont inséparables.

Mots-clés : Luís da Câmara Cascudo, correspondance, archives de la création, réseaux de sociabilité intellectuelle, Modernisme, Régionalisme Traditionnaliste du Nord-Est. 
Em memória de minha avó Francisca Queiroga Ponce Leon e do Sr. Pedro Elias de Araújo que devido aos desígnios da providencia divina não estão mais entre nós para conosco vislumbrar este momento. 
Dedico esta tese para minha menina, mulher, amada e companheira Isabel Cristina Araújo Brandão. Que o trabalho concluído seja a chave que abra a porta de todos os sonhos que estão por vir. 
Você sabe que uma carta minha é sempre um pedido de informação sobre cousa velha. Contínuo cada vez mais... o mesmo. Desta feita a conversa é assim... (Luís da Câmara Cascudo ao se dirigir a Mário Sette em carta de 21-IV-1945). 


\section{AGRADECIMENTOS}

Agradeço a Deus por ter me conduzido até aqui e ter me dado forças para mudar o que pôde ser mudado; além da resignação em aceitar o que não pôde ocorrer de outro modo.

A meu orientador, Dr. Marcos Silva, por ter acreditado na viabilidade deste projeto de vida e de pesquisa.

Aos membros que compõem a banca examinação desta tese: Dr. Marcos A. de Moraes, Dra. Gabriela Pellegrino Soares, Dra. Marisa Lajolo e Dra. Marinalva Vilar de Lima pelo diálogo e aprendizado estabelecido em um momento tão precioso.

À amiga e irmã acadêmica Poliana Santos, por ter me ajudado com a pesquisa na Biblioteca da PUC-SP e no Acervo do IEB/USP.

Aos amigos e pesquisadores: Diego José Fernandes Freitas, Francisco Firmino Sales Neto, Humberto Hermenegildo de Araújo, José Luiz Ferreira e Tarcísio Gurgel pelo diálogo, por toda a ajuda prestada e abertura de seus acervos particulares para complementação dos estudos e análise dos dados referentes a minha tese de doutorado.

A Ana Maria Cascudo (in memoriam), Daliana Cascudo e ao Ludovicus Instituto Câmara Cascudo pelos importantes esclarecimentos e pela disponibilização do acervo de Luís da Câmara Cascudo.

À Fundação Casa de José Américo de Almeida representada aqui na figura de uma de suas funcionárias, a amiga Ana Gomes, que sempre atendeu prontamente aos meus pedidos e solicitações.

Aos amigos Eli Clemente, Soninha, D. Inácia, Edson e Lucilene, Lourival, Sueli e Cinthia por me ajudarem a suavizar a saudade das coisas, pessoas e lugares do Nordeste durante a minha estadia em São Paulo.

A meus pais e demais familiares (tios, primos, irmãos, sobrinhas, etc.).

A minha esposa Isabel Cristina Araújo Brandão, a meu sogro Luiz Pereira Brandão e a minha sogra Glória Maria Araújo Brandão, deixo o agradecimento especial, pois sem eles nada disso seria possível. Recebam meu amor, meu carinho e minha gratidão eterna. 


\section{LISTA DE ABREVIAÇÕES}

AF: Ascenso Ferreira

BSS: Braulio Sanchez-Saez

CC: Luís da Câmara Cascudo

GA: Guilherme Auler

GF: Gilberto Freyre

JAA: José Américo de Almeida

LES: Luís Emilio Soto
MA: Mario de Andrade

MB: Manuel Bandeira

ML: Monteiro Lobato

POB: Pedro de Orléans Bragança

RP: Rocha Pombo

VM: Veríssimo de Melo 


\section{SUMÁRIO}

1. Introdução: Itinerários de uma pesquisa: os caminhos que nos levaram ao Cascudo epistológrafo.

2. Capítulo I: "OCUPAR-SE PARA NÃO PREOCUPAR-SE": amizade, envelhecimento e escrita de si na epistolografia cascudeana

2.1. A epistolografia cascudeana ontem e hoje.

2.2. Sobre a escrita de si e a correspondência cascudeana publicada em livros.

2.3. Mensagens de Câmara Cascudo a Thadeu Villar de Lemos.

2.4. "Como tenho a doutrina de transmitir as notícias jasmins e esquecer as xique-xique, levo essas às suas futuramente venerandas orelhas": cartas de Cascudo a João Lyra Filho.

2.5. "Um bom abraço deste seu velho": cartas de Cascudo para Oswald Lamartine.....

3. Capítulo II: DAS CARTAS COMO DOCUMENTAÇÃO E MONUMENTALIZAÇÃO: os estudos sobre a correspondência entre Câmara Cascudo e Mário de Andrade em perspectiva historiográfica.

3.1. Sobre a crítica dos documentos/monumentos: o Cascudo modernista.

3.2. Primeiro momento: Veríssimo de Melo (1971-1998)

3.3. Segundo momento: Vânia Gico (1998).

3.4. Terceiro momento: Edna Maria de Sá Gomes (1999).

3.5. Quarto momento: Silvia Ilg Byngton (2000)....

3.6. Quinto e último momento: Aluísio Lins Oliveira, Cláudio Augusto Pinto

Galvão, Dácio Tavares de Freitas Galvão, Mateus Silveira Lima e Mariana Corção (2008-2014).

3.7. Outras redes, novos sentidos: a correspondência passiva de Cascudo.

3.7.1. Monteiro Lobato (1920-1944).

3.7.2. Rocha Pombo (1920-1928)

3.7.3. Pedro de Orleans Bragança (1924-1938) e Guilherme Auler (19421962) 


\section{Capítulo III: "ENTRE OS ARTISTAS AMIGOS O MOMENTO BOM DE TERNURA É O APARECIMENTO DE OBRA NOVA": $a$}

correspondência entre Luís da Câmara Cascudo, Mário de Andrade e Joaquim Inojosa (1924-1928)

4.1. A rede de sociabilidade Mário, Cascudo e Inojosa: os arquivos da criação modernista no Nordeste.

4.2. A correspondência de Câmara Cascudo e Mário de Andrade (19241928)

4.2.1. Recepção e crítica de poesias.

4.2.2. A correspondência como espaço de socialização com outros poetas:

Manuel Bandeira, Ascenso Ferreira e a vanguarda argentina.

4.2.3. As obras e os projetos literários de Mário e Cascudo mencionados no corpo da correspondência

4.3. Correspondência de Câmara Cascudo e Joaquim Inojosa (19241926)

4.4. Correspondência de Joaquim Inojosa e Mário de Andrade (1924-1928)....

5. Capítulo IV: MEMÓRIAS DO MOVIMENTO MODERNISTA EM PERNAMBUCO (E ADJACÊNCIAS): a correspondência de Joaquim Inojosa, José Américo de Almeida e Luís da Câmara Cascudo (19681984)

5.1. O Movimento Modernista em Pernambuco de Joaquim Inojosa: um livro como lugar de memória.

5.2. A contribuição de José Américo de Almeida para o Movimento Modernista em Pernambuco: correspondência e crítica genética (19661968)

5.3. "E agora, eis me chega o Cascudo puro, purinho...forte de espírito e amizade redevivo em tudo": memórias modernistas na correspondência de Cascudo e Inojosa (1968-1984).

5.4. Crítica a Gilberto Freyre e ao movimento regionalista na correspondência de Joaquim Inojosa, com José Américo e Câmara Cascudo (1968-1978). 
6. Capítulo V: CONGRESSO REGIONALISTA DO NORDESTE “QUE TENHO EU COM ELE?" - a correspondência entre Câmara Cascudo, Gilberto Freyre e José Américo de Almeida (19221978)

6.1. A relação de Câmara Cascudo com o regionalismo tradicionalista nordestino de Gilberto Freyre: embates teóricos no campo da História e das Letras

6.2. A correspondência entre Câmara Cascudo e Gilberto Freyre (19231976)

6.3. A correspondência de Câmara Cascudo e José Américo de Almeida (1922-1978)...

7. Conclusão: Para Além do Modernismo e do Regionalismo: a correspondência cascudeana novos itinerários de pesquisa.. 


\section{Introdução:}

Itinerários de uma pesquisa: os caminhos que nos levaram ao Cascudo epistológrafo

O nosso contato com o estudo da vida e obra de Luís da Câmara Cascudo ocorreu ao longo desses dez últimos anos. Inicialmente, adentramos nessa seara por intermédio dos estudos de gênero. $\mathrm{O}$ esboço de nossa pesquisa de mestrado surgiu ainda na graduação e posteriormente continuada no Programa de Pós-Graduação em Ciências Sociais na Universidade Federal de Campina Grande sendo publicada pela EDUFCG em 2009 (OLIVEIRA, 2009), e embora tenhamos obtido êxito em demonstrar que o feminino nos seus escritos sobre folclore e etnografia serviu como elemento de preservação da tradição e da cultura-popular-nordestina, chegamos a perceber que este não seria um viés finalista para interpretação e compreensão de seu pensamento sobre o feminino, pois o próprio autor demonstrou uma maneira diferenciada de conceber sua relação com as mulheres, tanto em sua vida intima (mãe, esposa, filha, netas), como na relação com as mulheres intelectuais de seu tempo.

E nesse sentido, o autor se coloca de forma inovadora, principalmente se levarmos em conta, inicialmente, a referência feita a algumas poetisas norte-riograndenses em sua produção bibliográfica, tais como Auta de Souza e Palmyra Wanderley; sem contar sua estreita relação com Zila Mamede, poetisa e bibliotecária que ficou também conhecida pela organização do catálogo enciclopédico Luís da Câmara Cascudo - 50 anos de vida intelectual 1918-1968 (1970).

Embora tenhamos ainda interesse em tempos futuros em revisitar este debate que iniciamos no campo dos estudos cascudeanos, constatamos desde o início sua posição multifacetada no campo do pensamento, seu livre trânsito pelas teorias, e estilos de escrita, ora literário, histórico, biográfico, etnográfico, jornalístico, poético, epistolográfico, etc.; quando ainda realizando o levantamento bibliográfico para a realização de minha pesquisa de mestrado Luís da Câmara Cascudo e a invenção do “feminino" na “cultura-popular-nordestina” (1938-1977), pelos idos de 2007 a 2008, 
deparamo-nos com o livro Cartas de Mário de Andrade a Luís da Câmara Cascudo (2000) organizado por Veríssimo de Melo ${ }^{1}$.

Confessamos que as cartas de Mário para Cascudo foram lidas com muita curiosidade, e uma coisa que nos causava estranhamento era o fato de o volume não incluir a publicação das cartas de Cascudo para Mário. A impressão que tínhamos era a de quem por algum motivo, intercepta alguém, conversando ao telefone com outrem, embora possa se captar a essência do diálogo, fica faltando sempre o outro lado da interlocução. Só com a publicação de Câmara Cascudo e Mário de Andrade: cartas, 1924-1944, organizado por Marcos Antonio de Moraes em 2010 é que pudemos tomar conhecimento do respectivo diálogo em sua integridade.

Concordamos com Marcos Antonio de Moraes (2010), quando este afirmou que a vida da correspondência entre Mário e Cascudo espelha, com nitidez, o percurso intelectual dos interlocutores. Livros, textos em jornais e revistas, obras de imaginação ou estudos, trocados entre eles, aguardam a "opinião franca" dos novos estudiosos. Segundo aquele pesquisador, a amizade entre eles consolida-se nas cartas, ao longo desses anos, passando das afinidades intelectuais para as desejadas relações familiares de compadrio, sem excluir momentos de tensão. Leva a reboque a depreciação ou a valorização de um determinado ideário artístico ou concepção ideológica, suscitando, eventualmente, debates (MORAES, 2010, p. 373-374).

Nas idas e vindas ao Memorial Câmara Cascudo ${ }^{2}$, tivemos a oportunidade de conhecer Francisco Firmino Sales Neto, e de ser presenteado com o seu livro de estreia Palavras que silenciam: Câmara Cascudo e o Regionalismo-tradicionalista nordestino (2008), que nos chamou a atenção por estabelecer uma crítica a Veríssimo de Melo - o organizador do primeiro livro supracitado - e a uma série de outros estudos, com ênfase em Araújo (1995) e Ferreira (2001), que tomavam a relação de Mário de Andrade com Luís da Câmara Cascudo, e o Modernismo, como chave interpretativa da obra do etnógrafo potiguar. Em linhas gerais, Sales Neto tencionou mostrar como foi elaborada uma versão para esse capítulo da biografia intelectual de Cascudo, que obliterava em

\footnotetext{
${ }^{1}$ Veríssimo de Melo nasceu no dia 9 de julho de 1921, na cidade de Natal. Concluiu o curso de bacharel em Ciências Jurídicas e Sociais pela Faculdade de Direito do Recife, exercendo as funções de advogado, juiz municipal, professor de Etnografia do Brasil da Faculdade de Filosofia de Natal e de Antropologia Cultural da Universidade Federal Rio Grande do Norte, além de jornalista. Em 1989, depois de aposentado, Veríssimo de Melo dedicou-se, com mais afinco, aos estudos folclóricos e ao jornalismo. Foi, também, membro do Conselho Estadual de Cultura e da Academia Norte-Riograndense de Letras. Faleceu no dia 18 de agosto (mês do folclore) de 1996, em Natal, RN.

${ }^{2} \mathrm{Na}$ época, o Ludovicus - Instituto Câmara Cascudo ainda não existia e todo o acervo de Câmara Cascudo estava resguardado no Memorial Câmara Cascudo.
} 
seu entender as relações de Cascudo com o Movimento Regionalista-Tradicionalista, com Gilberto Freyre ${ }^{3}$ e José Américo de Almeida. O autor buscou, portanto, "romper com o silêncio em torno do Cascudo regionalista" (SALES NETO, 2008, p. 19).

No ano de 2012, tivemos a oportunidade de conhecer Humberto Hermenegildo de Araújo e seu estudo sobre a correspondência de Joaquim Inojosa com Câmara Cascudo, Consciência moderna e movimentos: o Modernismo nas cartas trocadas entre Câmara Cascudo e Joaquim Inojosa, que identificou e coletou todas as cartas de Câmara Cascudo enviadas a Joaquim Inojosa disponíveis no Acervo do Arquivo Museu de Literatura Brasileira da Fundação Casa de Rui Barbosa, no Rio de Janeiro. Concomitantemente à catalogação das cartas de Joaquim Inojosa enviadas a Cascudo com a equipe do Ludovicus - Instituto Câmara Cascudo. Araújo (2012) -, realizou a leitura da correspondência entre os dois intelectuais nordestinos, demonstrando que esta epistolografia se vincula ao estudo da história e da vida literária brasileira, com ênfase para a reflexão sobre a literatura produzida em espaços considerados periféricos do país e em períodos de modernização.

Por intermédio do estudo de Araújo (2012), tomamos conhecimento de Joaquim Inojosa e sua obra O Movimento Modernista em Pernambuco (1968-1969), que nos fez perceber a relação do mesmo não só com Cascudo, mas com Mário de Andrade e José Américo de Almeida; e da crítica estabelecida por Inojosa ao sociólogo Gilberto Freyre e a seu Regionalismo tradicionalista; isso motivou-nos a fazer um estudo da epistolografia de Luís da Câmara Cascudo com Mário de Andrade, Joaquim Inojosa, Gilberto Freyre e José Américo de Almeida de 1922 a 1984.

Em conversa prévia com a diretora do Ludovicus - Instituto Câmara Cascudo, Daliana Cascudo, foi possível tomar conhecimento da existência de cartas de Gilberto Freyre, onze no total (enviadas nos anos de 1923, 1966, 1968, 1974, 1976, 1978); e de José Américo de Almeida - quinze cartas (enviadas nos anos de 1922, 1924, 1972, 1973,1977, 1978); daí, portanto, o estabelecimento do respectivo recorte temporal, para que se possa contemplar a periodicidade da correspondência de Cascudo com todos os intelectuais em questão. Tal documentação encontra-se inédita para os estudos aqui

\footnotetext{
${ }^{3}$ Embora não faça uso da correspondência como fonte privilegiada em sua pesquisa, é possível perceber que Sales Neto (2008) utilizou algumas cartas enviadas e recebidas por Câmara Cascudo. Entre estas, verificamos a existência de uma carta não datada, mas que tratou da aproximação de Cascudo com o projeto editorial do Livro do Nordeste (SALES NETO, 2008, p. 138-141). Essa mesma carta também foi abordada por Moraes (2010), em uma nota explicativa presente na compilação supracitada (CASCUDO, 2010a, p. 80). Trataremos da mesma na análise desenvolvida no quinto capítulo desta tese.
} 
referidos. Desse modo, o que irá balizar o recorte temporal da pesquisa será a primeira carta enviada por José Américo em 1922 e a última carta de Inojosa recebida em 1984.

Através do levantamento inicial das fontes e das leituras estabelecidas sobre a obra de Luís da Câmara Cascudo, buscamos transpor o debate historiográfico estabelecido em torno da delimitação da produção intelectual do escritor potiguar presa apenas ao Movimento Modernista ou ao Movimento Regionalista Tradicionalista do Nordeste.

Para pensarmos as questões que nortearam a elaboração desta tese, é preciso compreender em síntese o pano de fundo das ideias modernistas e do Regionalismotradicionalista-nordestino em estudos recentes.

Inicialmente, o Modernismo refere-se aos movimentos literários, artísticos e religiosos que ocorreram na Europa e noutras partes do mundo desde a segunda metade do século XIX, propondo o rompimento com a tradição passada e a construção de uma nova arte moderna e de uma Igreja Católica renovada. No campo artístico, os movimentos modernistas do século XIX - romantismo, impressionismo, surrealismo -, considerando as suas especificidades, tiveram propostas comuns que podem ser sintetizadas nos seguintes princípios: o questionamento dos pressupostos básicos da arte acadêmica e da tradição artística oficial; a afirmação da autonomia da arte, liberdade de criação artística, originalidade da obra de arte, genialidade do artista; a busca de novas soluções formais centradas na estrutura da obra de arte e nas estéticas pautadas pela teoria da arte pela arte (RIBEIRO, 2007, p. 117).

De acordo com Schwartz (2008), no final dos anos de 1920, já começa a se configurar como o ocaso dos movimentos vanguardistas, especialmente no que diz respeito ao seu caráter experimental. Se as vanguardas latino-americanas podem ser vistas como consequências dos "ismos" europeus, também neste caso as preocupações político-sociais das primeiras décadas dos anos 1930 são melhor compreendidas quando situadas em um contexto internacional. E embora o último dos "ismos" europeus seja o surrealismo, cujo primeiro manifesto data de 1924, na América Latina, é justamente o Movimento de Vanguarda da Nicarágua que representa, de maneira consistente, a última corrente de ruptura. A Semana de Arte Moderna no Brasil, conhecida também como Semana de 22, é um divisor de águas na cultura e nas artes do Brasil. O crítico uruguaio Ângel Rama, num artigo em que trata das vanguardas hispano-americana e brasileira como fenômeno cultural integrado, considera o histórico evento como o ingresso oficial das vanguardas na América Latina (SCHWARTZ, 2008, p. 49). 
Segundo Ribeiro (2007), a semana de 22, que teve lugar no Teatro Municipal de São Paulo, entre 11 e 17 de fevereiro, apresentou uma programação de conferências, recitais poéticos, concertos e exposição de artes plásticas, tomando como modelo a programação dos festivais de arte futuristas e dadaístas. O evento não aconteceu por acaso em São Paulo, mas teve como antecedente uma série de acontecimentos artísticos importantes, desde a polêmica exposição de Anita Malfatti ${ }^{4}$ em 1917, que provocou a ira do crítico Monteiro Lobato; até a organização de um grupo de artistas e intelectuais militantes, liderados por Mário e Oswald de Andrade, que questionavam a tradição artística e lutavam em prol de uma arte brasileira em consonância com as propostas das vanguardas europeias (RIBEIRO, 2007, p. 119).

A Semana de Arte Moderna de 1922 bateria às portas da Academia Brasileira de Letras dois anos mais tarde. No dia dezenove de junho de 1924, Graça Aranha, já inscrito numa das séries de conferências organizadas por Medeiros e Albuquerque, tomava a palavra para a palestra intitulada "O espírito moderno". Graça Aranha questionou por intermédio desta preleção os preceitos que até então vinham justificando a gloriosa existência da Academia. Segundo Aranha, o passado evocado pelos acadêmicos seria uma invenção, e sua tradição, festejada nas sessões solenes, resumindo-se a um "império de todas as velhices", onde os homens de letras eram representados como "espectros", desprovidos de suas essências e "delícias intelectuais". Declarando morte à Academia, Graça Aranha finalizou o seu discurso sob aplausos fervorosos e vaias iradas da plateia. Em meio ao tumulto generalizado, alguns membros da mesa e vários acadêmicos indignados retiraram-se da sala. Desde o seu regresso da Europa, em 1921, onde trabalhara anos seguidos no serviço diplomático, Graça Aranha vinha divulgando suas concepções sobre o pensamento moderno. Amigo pessoal de Paulo Prado, um dos principais organizadores da Semana de Arte Moderna, o autor de Canã̃ aceitara o convite para abrir o evento realizado no Teatro Municipal. Assim, no dia treze de fevereiro, Graça Aranha inaugurava a Semana de 1922, proferindo a conferência intitulada "A emoção estética na arte moderna", na qual protestava contra a imitação, o academicismo e a "pérfida sombra do passado", que acabavam por impedir a proliferação da verdadeira arte (EL FAR, 2000, p. 126-129).

\footnotetext{
${ }^{4}$ De acordo com Ionta (2007), as telas de Anita estavam situadas a quilômetros de distância dessas pinturas nacionais e, mais ainda, das pinturas femininas da época, vincadas pela delicadeza de assunto, cor ou pinceladas suaves. Assim, a novidade da exposição da artista, a curiosidade do público, a dificuldade de compreensão daquelas obras mantiveram a exposição muito frequentada, desde o dia em que foi aberta ao público, em treze de fevereiro de 1917, até fins de janeiro de 1918 (IONTA, 2007, p. $35)$.
} 
Em conformidade com Arruda (2011), cremos que o enraizamento das propostas modernistas no Brasil é, como se sabe, fenômeno característico dos anos de 1930, momento no qual se legitimou a nova gramática das obras e dos estilos, forjada, especialmente, no interior da geração vanguardista de São Paulo no decênio de 1920. Os desdobramentos ocorridos ultrapassam os significados usuais que transformações desse vulto provocam no universo da cultura, uma vez que, muito embora o Modernismo tenha sido na origem um fenômeno tipicamente de São Paulo, e mesmo do Rio de Janeiro, a fixação dos princípios vanguardistas só se realizou integralmente com a incorporação de outras regiões. As metrópoles são sempre os locais tradicionalmente de respiração das mudanças; no entanto, no âmbito da literatura, gênero mais enobrecido da cultura brasileira até então, as inovações do período fizeram-se sob o compasso de princípios diversos, embora também originais (ARRUDA, 2011, p. 191).

É fato que a Semana de Arte Moderna representou uma guinada na literatura e nas artes plásticas, como meio de recuperação de um passado a ser redescoberto pelo olhar modernista, erigindo a tradição sob os traços da novidade da forma, que foge da figuratividade plástica e da rigidez da linguagem literária ${ }^{5}$. Por outro lado, como demonstrou Santini (2014), essa proposta estética do grupo modernista inicial não encontrou resposta unânime nas diferentes regiões do país e permaneceu atrelada à esfera do desenvolvimento econômico e cultural de São Paulo e Rio de Janeiro, o que impulsionou a reação do grupo nordestino reunido em torno do pensamento de Gilberto Freyre, no Centro Regionalista do Nordeste, a partir de 1926. O fato é que o grupo Regionalista do Nordeste, embora sem grande repercussão na imprensa da época, apresentava uma contraface do Modernismo heroico de 22 ao colocar em cena uma realidade diversa daquela que fomentara o movimento modernista em um espaço geográfico que reconhecia como edificado sob o signo da modernidade: a criação do Centro Regionalista do Nordeste marca, portanto, a tentativa de quebra da hegemonia cultural do eixo Rio-São Paulo, fixando hábitos e tradições responsáveis pela definição do homem nordestino e pelo lugar que lhe era dado na esfera social (SANTINI, 2014, p. 118).

\footnotetext{
5 Conforme Miceli (2003), assim como Mário de Andrade procurou marcar distância em relação aos mestres consagrados do parnasianismo e inventar uma genealogia criativa em relação a algumas individualidades artísticas do período colonial (Alejadinho etc.), os baluartes da propaganda modernista nas artes plásticas buscaram evidenciar as diferenças entre as obras dos modernistas em comparação aos gêneros, temas e linguagens tradicionais do academicismo (MICELI, 2003, p. 99).
} 
Modernismo e Regionalismo: os anos 20 em Pernambuco (1996), de Neroaldo Pontes de Azevedo, publicado em 1984, propôs reconstituir a história da expansão do Modernismo da Semana de 1922 e a retomada do Regionalismo nos anos 1920 em Pernambuco, tomando como fontes primárias os jornais e revistas que circulavam em Recife naquela década. A investigação, no campo da história da literatura, inseria-se num projeto amplo de pesquisas de periódicos, iniciado na Universidade de São Paulo e com desdobramentos na Universidade Federal da Paraíba, que pretendia, conforme aparece na apresentação do livro, definir as repercussões do Modernismo no Nordeste. O pesquisador se constrói como mediador dos debates entre Joaquim Inojosa e Gilberto Freyre, ressaltando que modernistas e regionalistas, em suas obras e depoimentos, tinham interesse em salientar o mérito de sua atuação e de seu grupo, em detrimento uns dos outros, no que chamou de enganos propositais e, sobretudo, omissões. Nas considerações finais do livro, depois de apontar para a complexidade das relações entre modernistas e regionalistas na década de 1920 e dos envolvimentos das correntes estéticas com os grupos políticos locais, apresenta sua conclusão (BARROS, 2012, p. 21-22):

Com efeito, no início da década de 20, quando chegou a Pernambuco, através de Joaquim Inojosa, a notícia do movimento modernista eclodido no Sul do país, já se fazia sentir um apelo para a retomada do Regionalismo e já se delineava uma resposta, (...) A ação de Gilberto Freyre e as atividades do Centro Regionalista do Nordeste reforçarão tal tendência.

Evidentemente, o momento inicial foi de choque entre as duas correntes de ideias. Subjacente, porém, às discordâncias de propostas em torno da literatura ou da arte em geral, agia, como força viva, a luta local pelo poder político. A disputa entre 'modernistas' e 'regionalistas' era reflexo também, (...) das disputas entre facções oligárquicas que, em partidos opostos, aspiravam ao comando político no Estado (AZEVEDO, 1996, p. 175).

Após o resumo feito sobre as manifestações modernistas e regionalistas no Nordeste, pode-se afirmar que o Rio Grande do Norte conheceu os respectivos movimentos de uma forma análoga a outros estados nordestinos, influenciados pela agitação cultural do Recife. Da mesma forma, é possível estabelecer uma relação, guardando-se as devidas proporções, entre o papel exercido por Luís da Câmara 
Cascudo, no Rio Grande do Norte, e outros intelectuais como José Américo de Almeida na Paraíba, Gilberto Freyre e Joaquim Inojosa em Pernambuco, Mário de Andrade em São Paulo (ARAÚJO, 1995, p. 19).

Desse modo, embora a correspondência de Cascudo com os intelectuais aqui elencados seja o principal objeto de estudo desta análise para compor as condições de investigação da sociabilidade do etnógrafo potiguar, conforme se menciona acima, busca-se ainda pensar os possíveis nexos entre Modernismo e Regionalismo presentes em suas obras. Haverá nesse sentido uma análise do conteúdo de sua produção intelectual com os possíveis efeitos dessas relações sobre suas ideias, examinando até nas missivas de outros correspondentes, dentro do recorte temporal da pesquisa, aspectos referentes ao período contemporâneo aos movimentos, como sobre a memória de suas experiências posteriormente realizadas.

Na elaboração de nossa tese, não dissociamos o conhecimento das experiências cotidianas da vida. Buscamos respostas para questões antes ausentes dos estudos da história, mas nunca do cotidiano dos sujeitos históricos aqui elencados. A pesquisa em fontes como as correspondências de intelectuais reatualiza um diálogo que anima as reflexões. Desse modo, acompanhar as produções da rede de sociabilidade de Luís da Câmara Cascudo através de sua correspondência representa caminhar entre discursos, práticas, representações e temporalidades variadas. São relatos produzidos atendendo a interesses de momentos representados temporalmente como presente e passado em sua vida e de seus interlocutores. Por isso, haverá de se observar essa experiência diacrônica na estrutura dos capítulos. As temporalidades não serão tomadas numa lógica cronológica, mas atendendo às problemáticas interpostas na análise.

No primeiro capítulo "Ocupar-se para não Preocupar-se": amizade, envelhecimento e escrita de si na epistolografia cascudeana, trataremos do debate interposto sobre a epistolografia cascudeana, com ênfase nas correspondências ativas de Cascudo que foram editadas e publicadas ${ }^{6}$ antes e depois das Cartas de Mário de Andrade a Luís da Câmara Cascudo (2000), organizadas por Veríssimo de Melo. Cartas que tratam das relações de amizades e de assuntos culturais em termos mais

\footnotetext{
${ }^{6}$ Sendo respectivamente: Mensagens de Câmara Cascudo e Cosme Lemos, de Thadeu Villar de Lemos (1972); Apostila do Afeto: Câmara Cascudo - Cartas a Raimundo Nonato 1972-1979, de Raimundo Soares de Brito (1986); Câmara Cascudo do Potengi ao Piabanha (1989), de Francisco de Vasconcellos. Jasmins de Sobradinho (2000). Luis, toujours lui (2002), Flama Serena (2005), de Roberto da Silva e De Cascudo para Oswaldo, de Oswaldo Lamartine (2005).
} 
gerais com Thadeu Vilar de Lemos ${ }^{7}$, João Lyra Filho ${ }^{8}$ e Oswald Lamartine de Faria ${ }^{9}$. Nelas, é possível registrar alguns aspectos da vida intelectual brasileira no período que vai de 1966 a 1986. Pretendemos entreolhar outras facetas da biografia intelectual de Câmara Cascudo referentes às memórias de toda uma vida dedicada ao ensino na cidade de Natal, RN; dos livros, artigos, temas, e projetos editoriais da maturidade; do envelhecimento e suas limitações, além da glória referente ao sucesso do renome intelectual e autoral, principalmente pela contribuição ao campo da etnografia e do folclore.

No segundo capítulo, Das Cartas como Documentação e Monumentalização: os estudos sobre a correspondência de Câmara Cascudo e Mário de Andrade em perspectiva historiográfica, tomamos como ponto de partida a amizade entre Câmara Cascudo e Mário de Andrade, que tem sido referência obrigatória em qualquer narrativa da vida e obra de Cascudo. Analisar a década de 1920 no Rio Grande do Norte, em seus aspectos culturais, é quase exclusivamente tratar da aproximação de Câmara Cascudo com o movimento modernista, através da influência marioandradiana. Reproduz-se para Cascudo uma memória cristalizada de sua experiência modernista que, ao exaltá-lo, o insere no rol dos "grandes escritores modernistas" e que, em contrapartida, apaga outras experiências ocorridas naquele momento; sobretudo para um sujeito que experimentava a tensão do advento da modernidade em uma cidade provinciana como Natal, explica-lo unicamente através do Modernismo não seria uma atitude reducionista, não apagaria todas as contradições, todos os pontos conflitantes?

Nesse sentido, foi realizada uma análise onde se demonstra o processo de monumentalização da tese sobre o Cascudo modernista e de seus desdobramentos em estudos posteriores que fizeram referência à correspondência de Mário de Andrade e Câmara Cascudo de forma sistemática e/ou a reificação da tese em questão. Depois

\footnotetext{
7 Thadeu Villar de Lemos (1901-1979), jornalista, escritor, agente fiscal do imposto e do consumo, Comendador da Ordem de São Silvestre Papa; nasceu em Martins, RN, e faleceu em Niterói, RJ. Ingressou na imprensa em 1918, como redator do Diário A Imprensa, de Natal do qual era diretor Luís da Câmara Cascudo (LEMOS, 1972).

8 João Lyra Filho (1906-1988), jurista, financista, memorialista, biógrafo, epistológrafo, orador e professor, jornalista, poeta, contista e sociólogo, nasceu na atual cidade de João Pessoa, PB. Faleceu no Rio de Janeiro. Exerceu cargos na administração do Estado da Guanabara, atual Estado do Rio de Janeiro; entre estes: Secretário de Finanças do antigo Distrito Federal, ministro do tribunal de Contas do Estado da Guanabara e Reitor da Universidade do mesmo estado, atual UERJ (SILVA, 2005, p. 173-176).

9 Oswaldo Lamartine de Faria (1919-2007), sertanista, agrônomo e escritor, reconhecido o maior sertanista brasileiro por Raquel de Queiroz a Ariano Suassuna. Era detentor da cadeira de número 22 da Academia Norte-rio-grandense de Letras e autor de importantes obras da literatura potiguar. Formou-se técnico agrícola pela Escola Superior de Agricultura de Lavras, em Minas Gerais, e administrou fazendas no interior do RN, Rio de Janeiro e Maranhão. Foi técnico do Banco do Nordeste, professor da Escola Doméstica e da Escola Agrícola de Jundiaí -UFRN (CASTRO, 2015).
} 
disso, por intermédio das cartas enviadas por Monteiro Lobato, Rocha Pombo, Pedro de Orleans e Bragança \& Guilherme Auler, disponíveis no acervo do Ludovicus - Instituto Câmara Cascudo, buscou-se demonstrar com a respectiva seleção de interlocutores que para além do debate sobre o Modernismo no campo da crítica literária, houve durante o período de correspondência com Mário de Andrade a aproximação e o interesse de Câmara Cascudo em relação ao campo historiográfico, como a associação ao pensamento conservador monárquico.

No terceiro capítulo, "Entre os artistas amigos o momento bom de ternura é o aparecimento de obra nova": a correspondência entre Luís da Câmara Cascudo, Mário de Andrade e Joaquim Inojosa (1924-1928), voltaremos mais uma vez à correspondência de Mário e Cascudo, propondo uma leitura dessa correspondência em contraponto às séries epistolográficas de Câmara Cascudo com Joaquim Inojosa (19241926) e Mário de Andrade e Joaquim Inojosa (1924-1928). Temos como objetivo acompanhar o processo de criação das obras dos respectivos autores à época, como o processo de recepção e elaboração conjunta dos ideais modernistas no Nordeste. Cremos que a troca de correspondências dos referidos intelectuais são peças fundamentais da engrenagem dessa rede de sociabilidade modernista na região e que, por intermédio delas, é possível dar visibilidade a outros aspectos da biografia intelectual de Luís da Câmara Cascudo: sua relação com a escrita poética e a divulgação de alguma poesia, como de sua relação com a intelectualidade moderna platina.

No quarto capítulo, Memórias do Movimento Modernista em Pernambuco (e Adjacências): a correspondência de Joaquim Inojosa com José Américo de Almeida e Luís da Câmara Cascudo (1966-1984); a obra O Movimento Modernista em Pernambuco (1968-1969), de Joaquim Inojosa, será aqui tratada apenas nos aspectos em que corrobora para a articulação dos seus arquivos da criação; intercalado pela rede de sociabilidade intelectual estabelecida através de sua correspondência com José Américo de Almeida e Luís da Câmara Cascudo, tomando-a, como um significativo "lugar de memória", sendo, pois, pensada como campo de construção de genealogias, representações e inscrições do intelectual Inojosa na história do Modernismo (BARROS, 2012, p. 118).

No último capítulo da tese, intitulado Congresso Regionalista do Nordeste "que tenho eu com ele?" - a correspondência entre Câmara Cascudo, Gilberto Freyre e José Américo de Almeida (1922-1978), pretendemos demonstrar que Cascudo, mesmo tendo estabelecido uma rede de sociabilidade intelectual "modernista", não deixou de 
estabelecer contatos com uma rede de sociabilidade intelectual "regionalista". Embora as respectivas correspondências não estabeleçam um circuito fechado de diálogos e ideias entre os interlocutores mencionados, é possível, por intermédio de um cotejamento minucioso das fontes, remontarmos aspectos desta experiência regionalista e de sua relevância para a formação intelectual de Luís da Câmara Cascudo.

Estudos sobre a epistolografia parecem estar em alta nos últimos tempos. No caso de correspondências entre escritores, os estudos literários costumam privilegiar certas abordagens, destacando-se entre elas o recurso a cartas como fonte: a) para estudo da gênese da obra; b) para o estabelecimento de perfis biográficos; c) para o levantamento de ideias estéticas abraçadas pelo escritor; e d) para o estabelecimento da influência recebida ou exercida por ele (LAJOLO, 2013, p. 18).

Com a respectiva disposição da análise anteriormente apresentada, acreditamos que poderemos selecionar momentos significativos, as conexões que dão coerência à vida de uma pessoa e, assim, construir uma continuidade de atos que são descontínuos, justapostos, imprevistos e aleatórios. Nesse universo aparentemente caótico da experiência humana, o habitus, enquanto disposições incorporadas para sentir, pensar e agir permite o ordenamento e a unificação de práticas, ações, comportamentos e representações que convergem para a compreensão do eu, da identidade do sujeito, mas também de uma dada sociedade na qual o indivíduo se movimenta (BOURDIEU, 2007, p. 191; MALATIAN, 2011, p. 201).

O trabalho com correspondência privada de intelectuais vem crescendo entre os estudiosos da História Intelectual na medida em que tal fonte/objeto é apontada/o como um lugar de sociabilidade fundamental e revelador da dinâmica de um campo cultural de um dado período. O conceito de lugar de sociabilidade, entendido tanto como espaço de constituição de uma rede organizacional (que pode ser mais ou menos formal/institucional), quanto um microcosmo de relações afetivas (de aproximação e/ou de rejeição), tem-se afirmado como de particular utilidade para tais análises. Isso se deve ao fato de os intelectuais terem evidenciado que a atividade epistolar era uma prática disseminada e exercida com afinco e prazer pela maioria deles, que não só escrevia muitas cartas, como se aplicava a guardar as cartas que recebia, para a alegria dos pesquisadores que hoje sobre elas se debruçam. Dessa forma, a correspondência, como parte da obra de um autor, assegura uma aproximação das formas de estruturação do campo intelectual em dado momento e lugar, permitindo que se investigue de que 
maneira funciona esse "pequeno mundo" e de como se deve entender a própria noção de intelectual ${ }^{10}$ (BOURDIEU, 2007, p. 192; GOMES, 2005, p. 13).

Instrumento analítico e/ou categoria histórica, a sociabilidade será aqui tratada também em sentido mais estrito: como um conjunto de formas de conviver com os pares, como um "domínio intermediário" entre a família e a comunidade cívica obrigatória. A linguagem mais corrente utiliza o termo "rede" para definir os vínculos que reúnem o "pequeno mundo" intelectual. A história dos intelectuais vem consagrando o uso da noção de sociabilidade. As redes de sociabilidade são entendidas assim como formando um "grupo permanente ou temporário, qualquer que seja seu grau de institucionalização, no qual se escolha participar" (GOMES, 1993, p.64).

O gênero epistolar é aqui concebido como "arquivo da criação", espaço onde se encontram fixadas a gênese e as diversas etapas de elaboração de uma obra artística, desde o embrião do projeto até o debate sobre a recepção crítica favorecendo sua eventual reelaboração. A carta, nesse sentido, ocupa estatuto de crônica de obra de arte. A crítica genética, ao considerar a epistolografia um "canteiro de obras" ou um "ateliê", busca descortinar a trama da invenção, o desenho de um ideal estético, quando examina as faces dos processos da criação. Nessa última direção, tanto mais fértil será o terreno epistolar, quando os interlocutores definem contratos mais ou menos explícitos, nos quais a troca de opinião sobre trabalhos em desenvolvimento fundamenta os passos da criação, muitas vezes vista como ação compartilhada. Essas cartas tornam-se espaços testemunhais que logram tanto historiar fases do pensamento estético dos interlocutores, quanto dar contornos crítico-interpretativos ao momento em análise (MORAES, 2007b, p. 30).

José-Luis Diaz (2007), em seu importante artigo Qual genética para as correspondências? sugere a organização desse material heterogêneo, ao pensar na necessidade de se "compreender sobre quais 'momentos' da gênese as trocas epistolares convergem preferencialmente: elaboração pré-escritural (inventio), organização (dispositivo), formulação estilística (elocutio), ou ainda (...) após o evento da publicação. O que nos lembra que a gênese é um processo interminável, que não se conclui nem mesmo após a morte do autor, e que se prolonga por toda a pesquisa genética posterior” (...). Resta, finalmente, ao estudioso da crítica genética, diante de

\footnotetext{
${ }^{10}$ A noção de sociabilidade refere-se aos locais de produção dos intelectuais e às trocas neles ocorridas. Segundo Sirinelli (2003), a palavra sociabilidade reveste-se de uma dupla acepção: ao mesmo tempo "redes", que estruturam, e "microclimas", que caracterizam um microcosmo intelectual, particular (SIRINELLI, 2003, p. 248; 253).
} 
um dossiê amplo de confidências e reflexões, superar as contradições presentes nos relatos, bem como as eventuais ficções da gênese e as armadilhas do memorialismo. Argumenta ainda que os estudiosos do memorialismo e os historiadores levam em conta que toda carta propicia a formulação de personae, pois o sujeito molda-se como personagem em face do interlocutor. Essa invenção de si (mise-en-scène), da qual o remetente pode ter maior ou menor grau de consciência, forja sempre estratégias de sedução. Tornando-se ainda mais complexa a natureza do gênero epistolográfico, devese considerar que a carta encontra-se ancorada em um ponto da trajetória de vida do sujeito. Em vista disso, uma ideia solidamente defendida em certo momento poderá ser reformulada ao longo da correspondência, modificando-se até atingir o campo diametralmente oposto (DIAZ, 2007, p. 125-127).

A carta como "arquivo da criação" proporciona valiosos elementos de fonte primária para os estudiosos da literatura e de outras artes, da mesma forma que fornece subsídio para as percepções teóricas da crítica genética. Apresenta, contudo, uma problemática específica, que nos faz recusar soluções interpretativas fáceis ou ingênuas, resultantes de deslumbramentos (MORAES, 2007b, p. 31-32).

Foi através da articulação desses conceitos provenientes do campo da História Intelectual e da Crítica Genética que desenvolvemos a respectiva tese de doutorado. Esperamos que a mesma venha a contribuir significativamente com os campos de estudo da obra de Luís da Câmara Cascudo e dos interlocutores aqui selecionados. 


\title{
2. Capítulo I:
}

\section{“OCUPAR-SE PARA NÃO PREOCUPAR-SE":}

amizade, envelhecimento e escrita de si na epistolografia cascudeana

\begin{abstract}
O escritor constituindo glória em sua amizade, no envio de uma missiva, no soar de um louvor. Visitado como um soberano. Exaltado como um ídolo.

- Sim. É verdade. Escrevi milhares de cartas, súplicas, pedidos, auxílios, subvenções, moedas de ouro. Mendigo por correspondência. Não me arrendei, vendi, aluguei. Todos os golpes de ameaça e sedução, aparei-os com a pena de pato (CASCUDO, 1974, p. 117).
\end{abstract}

\subsection{A Epistolografia cascudeana ontem e hoje}

A epígrafe que abre este capítulo provém de um dos livros mais complexos de Luís da Câmara Cascudo; Prelúdio e Fuga do Real (1974), obra composta em literatura tropicalmente polifônica. Preludiando ou sendo preludiado, referenciam-se as cumplicidades entre jornalismo e literatura, paixão e crítica, erudição e coloquialismo, envolvidos em ambiência de reflexão filosofante. Suas palavras são de mão dupla: confidências e interlocuções, confissões e divergências, tudo em desejável reciprocidade. Como autor que fosse ao mesmo tempo roteirista-dramaturgo-encenadorcineasta, Cascudo faz, antes de tudo, a locação mais exata e atraente para seu personagem. E, embora seja a fala atribuída a Erasmo de Roterdã (1466-1536), o protagonista aqui invocado, fiel e religiosamente, é persona ou "máscara" dele mesmo (BRITTO, 2003, p. 244-245).

Cascudo, tal qual Erasmo, foi "escritor constituindo glória em sua amizade, no envio de uma missiva, no soar de um louvor. Visitado como um soberano. Exaltado como um ídolo". Quantas pessoas vindas dos mais variados lugares do Brasil e do mundo não subiram as escadas da casa de Câmara Cascudo, na antiga Junqueira Aires (atual Av. Câmara Cascudo), em Natal, Rio Grande do Norte, para vê-lo e ouvi-lo? Escreveu sem sombra de dúvidas "milhares de cartas, suplicas, pedidos, auxílios" para a elaboração de suas pesquisas e produção de todo o corpus de sua obra.

Sendo uma importante fonte para coleta de dados, nominava sua correspondência, em que solicitava informações de pesquisa aos amigos e colegas pesquisadores e instituições, de "inquéritos diretos", "cartas perguntadeiras" e 
correspondência precatória, como por fim consagrou chama-las. Enquanto suas cadernetas de notas guardavam anotações pessoais, as cartas eram textos sempre destinados aos outros. As cartas, para Cascudo constituíam uma maneira de mostrar-se a si próprio, como fez em tantas passagens de sua obra. A escrita de si, que particularizou em especial, suas memórias nos livros O Tempo e Eu, Ontem, Na Ronda do Tempo e Manual do Doente Aprendiz (GICO, 1998, p. 70; OLIVEIRA, 2009, p. 23-45).

Sendo assim, a correspondência precatória tanto fala do cotidiano particular e da família, quanto da produção de sua obra. Neste caso, solicitava abertamente tudo que precisava para escrever seus livros, e não estava ao alcance "geográfico": informações de bibliotecas, arquivos, museus, dados de família e profissionais dos estudiosos que estava referenciando e até mesmo coleta de dados de campo eram pedidos, e lhe vinham por correspondência das "vítimas indefesas", como costumava apelidar amigos escolhidos em Estados brasileiros ou em pontos estratégicos do exterior para fornecerem-lhe tais informações. Detalhava os pedidos, orientando o levantamento de dados, e indicando as minúcias que desejava para cada assunto com que estava ocupado. Também compunham esta correspondência dificuldades, dúvidas e estágios de desenvolvimento dos assuntos que vinha estudando (MELO, 1989, p. 16-17). Desse modo, suas missivas eram um veículo singular de disseminação, da informação, divulgação e recebimento de notícias editoriais, já que, ele próprio, estava tão distante dos ciclos mais ativos das discussões em voga neste campo, não admitindo a falta de compromisso para "responder cartas" e manifestava publicamente sua opinião, como fez em sua coluna Acta Diurna do jornal A República, em julho de 1943 (GICO, 1998, p. 70-71):

Um dos nossos hábitos comodistas é não responder cartas ou retardar indefinidamente a satisfação desse dever. Há, naturalmente, cartas que só merecem silêncio. Outras exigem o cumprimento imediato. São consultas, por exemplo, que esclarecerão dúvidas.

São informações para quem está estudando um assunto. Raramente, muito raramente, registo uma falta de resposta. Houve, entretanto, anos passados, um episódio digno de registo. Estava eu escrevendo $\mathrm{O}$ MARQUÊS DE OLINDA E SEU TEMPO, que a 'Brasiliana' de S. Paulo publicou. Ia juntando documentos, adquirindo livros, forjando o ambiente, sem bibliotecas e arquivos.

Numa manhã registei quatro cartas. Uma para o Prefeito de Polícia de Paris, mr. Chiappe. 
Outra para o Príncipe Max de Saxe, professor na Universidade de Basiléia. Outra para o prof. Fezas Vidal, Reitor da Universidade de Coimbra.

A última, para o Rio de Janeiro, era a mais próxima e mais fácil. Tratava-se de um exemplar de uma publicação oficial, comprada, dada ou emprestada. O destinatário, grande político, uma tradição de polidez e de inteligência, compreenderia tudo. Recebi respostas da Suiça, da França e de Portugal.

Recebi quanto pedira, relatório, notas, cópias autenticadas, com frases amáveis e cativantes.

Do meu patrício brasileiro, o político amabilíssimo, nunca chegou às mãos uma linha siquer. Não espero mais porque ele morreu. Está perdoado e creio que Deus fez o mesmo para com su'alma... (CASCUDO, 1943).

A epistolografia cascudeana fomentou ao longo dessas últimas décadas do século XX e no início do século XXI inúmeras obras que a tomam como objeto de conhecimento. Essa história pode ser dividida em três fases. Uma primeira, que é transcorrida entre as décadas de 1970 e 1980; uma segunda, da década de 1990; e a terceira, que se inicia no ano 2000, até o presente momento (ARAÚJO, 2007, p. 244245). Nas décadas de 1970 e 1980, foram editadas correspondências que envolveram relações de amizade e mais espaço para tratar de assuntos culturais em termos gerais. Entre estas, encontramos Mensagens de Câmara Cascudo e Cosme Lemos, organizado por Thadeu Villar de Lemos (1972); Apostila do Afeto: Câmara Cascudo - Cartas a Raimundo Nonato 1972-1979, coordenado por Raimundo Soares de Brito (1986); e Câmara Cascudo do Potengi ao Piabanha (1989), elaborado por Francisco de Vasconcellos. Na década de 90, o nome a ser destacado é o de Veríssimo de Melo, que promoveu em 1993 a edição das Cartas de Mário de Andrade a Luís da Câmara Cascudo (2000) e publicou artigos de Mário e Cascudo que demonstram ser de tal correspondência, foi o responsável em despertar o interesse por essas missivas modernistas.

Ainda na década de 1990, Vânia Gico, em sua tese de doutorado Luís da Câmara Cascudo: itinerário de um pensador (1998), apresentada ao Programa de PósGraduação em Ciências Sociais na PUC-SP, divulga várias cartas de Câmara Cascudo a Josué de Castro e Nunes Pereira, entre outros pesquisadores. Finalizando a década, temos a dissertação de mestrado Correspondências: leitura das cartas trocadas entre 
Luís da Câmara Cascudo e Mário de Andrade (1999), de Edna Maria Rangel Sá Gomes, defendida em 1999 junto ao Programa de Pós-Graduação em Estudos da Linguagem da UFRN, onde foi apresentada a coleta das cartas trocadas entre Câmara Cascudo e Mário, ao longo de três décadas, numa pesquisa realizada no IEB/ USP e no Memorial Câmara Cascudo (ARAÚJO, 2007, p. 245-246).

Já na terceira fase, a partir do ano 2000, com outra defesa de dissertação, temos o trabalho Pentimentos Modernistas - As cores do Brasil na correspondência entre Luís da Câmara Cascudo e Mário de Andrade (2000), de Sílvia Ilg Byington, defendida junto ao Programa de Pós-Graduação em História Social da Cultura da PUC do Rio de Janeiro. Também nessa época, Roberto da Silva apresentou três iniciativas em torno da epistolografia cascudeana. A primeira delas, um catálogo das cartas enviadas por Câmara Cascudo a João Lyra Filho, intitulado Jasmins de Sobradinho (2000). A segunda, Luis, toujours lui (2002), trata das missivas de Cascudo enviadas a Bernard Alléguede. A terceira, intitulada Flama Serena (2005), que é a retomada da primeira obra, só que com a publicação integral das cartas enviadas por Cascudo a João Lyra Filho. Ainda no ano de 2005, tivemos De Cascudo para Oswaldo, onde Oswaldo Lamartine publica as cartas de Cascudo que lhe foram enviadas (Id. Ibidem, p. 246247).

Em 2010, com trabalho de crítica textual e edição de Marcos Antônio de Moraes (prêmio Jabuti 2011, na categoria Teoria/Crítica literária), a compilação Câmara Cascudo e Mário de Andrade: cartas, 1924-1944 nos fornece o alcance e as dimensões da amizade entre os dois. Nos primeiros anos, é possível observar o contato de ambos com escritores modernistas da América Latina, com o etnógrafo potiguar franqueando ao escritor paulista os principais nomes da pesquisa do folclore do Norte e Nordeste, assim como com músicos, contadores de história, curadores, etc. As aproximações entre o Modernismo literário brasileiro e a Antropologia, disciplina que se institucionalizava no Brasil nas primeiras décadas do século XX (com o papel pioneiro, no fim do século XIX, de Sylvio Romero), foram de toda ordem. A compilação em destaque nos remete a uma delas, a que toma o debate sobre as vias de conhecimento da identidade do povo brasileiro e seu meio - a pesquisa etnográfica - como o cerne de uma amizade mantida quase sempre com distância física por vinte anos, alimentada do confronto e aperfeiçoamento de métodos, estilos (AMOROSO, 2012, p. 177), sem perda de calor humano. 
No ano 2012, temos Consciência moderna e movimentos: o Modernismo nas cartas trocadas entre Câmara Cascudo e Joaquim Inojosa - relatório final de estágio de pós-doutorado junto ao Programa de Pós-Graduação em Teoria Literária e Literatura Comparada FFLCH/USP de Humberto Hermenegildo de Araújo (PPGEL/ UFRN). A atividade principal do relatório foi o estudo da Correspondência entre Câmara Cascudo e Joaquim Inojosa; realizada em meio ao processo de digitalização e catalogação das cartas, pela equipe do Ludovicus - Instituto Câmara Cascudo, localizado na cidade do Natal-RN. A pesquisa identificou e coletou todas as cartas de Câmara Cascudo enviadas a Joaquim Inojosa, as quais estão disponíveis no acervo do Arquivo Museu da Literatura Brasileira da Fundação Casa de Rui Barbosa, no Rio de Janeiro. Concomitantemente às coletas nos dois acervos citados, foram realizadas pelo pesquisador visitas ao Instituto de Estudos Brasileiros - IEB/USP, o que possibilitou a leitura de cartas enviadas por Joaquim Inojosa a Mário de Andrade, além de documentos históricos relacionados às temáticas contempladas na correspondência, sobretudo o Modernismo (ARAÚJO, 2012, p. 5).

\subsection{Sobre a escrita de si e a correspondência cascudeana publicada em livros}

O agenciamento de fontes primárias ou secundárias para a investigação histórica adquire sua condição por meio de um ato significativo, o de quem a preserva para o futuro, tanto quanto o de quem a recupera para o presente: é um construto, como narração ou as explicações teóricas o são. Tem a seu favor, porém, uma vantagem - sua materialidade, que lhe garante um núcleo estável, mesmo que a seu redor gravitem interesses ou no seu próprio cerne estes tenham se entranhado (BORDINI, 2005, p.19).

Dessas práticas de arquivamento do eu, destaca-se o que poderíamos chamar uma intenção autobiográfica. Em outras palavras, o caráter normativo e o processo de objetivação e de sujeição, que poderiam aparecer a princípio, cedem na verdade o lugar a um movimento de subjetivação. Das cartas que recebemos, jogamos algumas diretamente no lixo, outras são conservadas durante certo tempo, outras enfim são guardadas; com o passar do tempo, muitas vezes fazemos uma nova triagem. O mesmo acontece com as de nossa autoria: guardamos cópia de algumas, seja em razão do seu conteúdo, seja em razão do seu destinatário (ARTIÈRES, 1998, p. 10).

$\mathrm{Na}$ correspondência ativa e passiva, surgem as revelações, as confissões, as confidências de múltiplos sujeitos interessados no métier, sejam escritores ou amadores 
da literatura, parentes, amigos ou desconhecidos, desdobrando uma história privada da rede de relações que se configuraram entre dados existenciais, culturais, políticos, econômicos e artísticos, e a obra acabada. Logo, o fechamento do sentido textual das correspondências aqui analisadas delineia, por vias indiretas ou analógicas, as vicissitudes da vida privada do escritor, permitindo que sua intimidade transpareça. E, com isso, o desvelamento de seus momentos de crise ou de entusiasmo, de derrota e vitória, forma-se uma imagem da subjetividade autoral não mitificada sob a aura da excepcionalidade criativa, mas humanizada nas hesitações, recuos e desejos satisfeitos ou frustrados, em interação com outras vidas (BORDINI, 2005, p. 20-21).

As cartas de Cascudo que foram editadas, além da correspondência com Mário de Andrade, são aquelas em que envolveram relações de amizades e mais espaços para tratar de assuntos culturais em termos gerais. Neste capítulo, enfocaremos as obras que tratam da correspondência com os amigos: João Lyra Filho, Thadeu Villar de Lemos e Oswaldo Lamartine de Faria; nelas, é possível registrar alguns aspectos da vida intelectual brasileira no período que vai de 1966 a 1986. Através do uso da metodologia da escrita de si (FOUCAULT, 1992; GOMES, 2004; IONTA, 2007, 2011, 2013), pretendemos entreolhar outras facetas da biografia intelectual de Câmara Cascudo; referentes às memórias de toda uma vida dedicada ao ensino na cidade de Natal, RN; dos livros, artigos, temas, e projetos editoriais da maturidade; do envelhecimento e suas limitações, além da glória referente ao sucesso do renome intelectual e autoral, principalmente pela contribuição ao campo da etnografia e do folclore. Que não necessariamente, esteve ligada com sua relação (ou não) com o movimento modernista e regionalista. Mas simplesmente por sua necessidade de "ocupar-se para não preocupar-se".

\subsection{Mensagens de Câmara Cascudo a Thadeu Villar de Lemos}

Thaville, é preciso ocupar-se para não preocupar-se. Alma ocupada não vive tentada (CC, 5-XI-1971, apud, LEMOS, 1972, p. 35).

Nas cartas enviadas para Thadeu Villar de Lemos, percebe-se que a amizade entre eles perdurou ao longo do tempo, a ponto de os netos de Cascudo também 
considerarem Lemos avô ${ }^{11}$. No período da correspondência divulgada, 1966-1972, Thaville, morava em Niterói e das centenas de cartas remetidas, Cascudo só autorizou para publicação 62 delas, as quais trazem mensagens afetivas e particulares. Nelas, também transparecem a preocupação com a obra e com a vida intelectual do escritor potiguar, como sua recusa em candidatar-se à Academia Brasileira de Letras ${ }^{12}$, o tombamento de sua biblioteca particular ${ }^{13}$. Também comentava o cansaço que já sentia com as constantes visitas e entrevistas ${ }^{14}$ (GICO, 1998, p. 71-72).

Estas "incessantes e amáveis visitas", de várias partes e tamanhos, obrigavamno a desrespeitar as ordens médicas. Estudantes perguntando, gente com gravadores, fotos incessantes. Não sabendo fingir desinteresse, "ligava os motores gastando seu pobre combustível septuagenário". Com a noite, ficava cansado e indignado com sua gentileza adversária à própria saúde, afinal de contas, ainda "trabalhava nas suas laboriosas inutilidades", como costumava ironizar nas cartas, através do seu grande senso de humor (CASCUDO, apud, LEMOS, 1972, p. 54-56).

Em novembro de 1966, Cascudo comenta a leitura de Páginas do Meu Arquivo, escrito por Thaville. Fala sobre os amigos comuns rememorados na obra, de como estava longe de esgotar o bem-querer sentido através da conquista sentimental que o livro lhe proporcionara. Diante dos cinquenta anos de amizade, o folclorista aconselha seu amigo:

Deus o abençoe e o tenha em sua divina guarda. Ocupe-se para não preocupar-se. Estou aposentado, 71 anos em dezembro, surdo, míope, jumentalmente otimista, e grudado na leitura, com os dedos na máquina. Um livro atrás do outro, numa obstinação de percevejo faminto. Não páre. Lembra-se do esquecido Marden? 'O Homem é como a bicicleta: parou, caiu'. Eu, nem no caixão pararei porque

\footnotetext{
11 "Li suas duas cartas, com aclamações de Dhalia, Daliana e Newton. Este socializou o envelope com a casa, dizendo que VOVÔ THADEU MANDOU PRA MIM! Dhalia e eu aprovamos os dizeres" Cf. (CC, 27-VIII-1971, apud, LEMOS, 1972, p. 30).

12، - não sou candidato senão a uma boa morte o mais tarde possível! Deu uma aragem na Academia local para fazer-me imorrível, mas consegui recuperar o direito de morrer. (...) Graças a Deus o Manoel Rodrigues, presidente da Academia, restituiu-me o papel que eu, esgotado e emocionado pelo assalto de ternura na noite de 18 de janeiro, assinara. E eles transformaram em petição para inscrição". Cf. (CC, 1III-1968, Id. Ibidem, p. 11).

13 "Notícia tombamento minha biblioteca é boato um tanto exagerado. Não houve, não há e provavelmente nada haverá no assunto, exceto na vontade de alguns fiéis sonhadores. Jamais tomarei a iniciativa no assunto" (CC, 11-IV- 1972, Id. Ibidem, p. 52-53).

14،"Estou um tanto fatigado. Converso, respondo, esgoto-me e daí ficar cansado como se atravessasse a Guanabara a nado. Final das contas, terei em dezembro 74 anos, mais 50 de esforço mental. Comecei em 1915 e a escrever três anos depois. É natural já não ter a resistência de outrora nem o entusiasmo para a vida social, da qual fujo a mil patadas, como centopeia”. Cf. (CC, 22-VIII-1972, Id. Ibidem, p. 56).
} 
católico, acredito na Vida eterna e essa não será Imobilidade $(\mathrm{CC}$, s.d.- XI-1966, Id. Ibidem, p. 9-10).

Noutra passagem, em carta de 23 de outubro de 1970, Cascudo fala de sua condição de "provinciano profissional" e do recebimento do Prêmio Brasília de 1970, pelas mãos do representante de Cascudo, Dr. Guimarães Lima, das coisas ditas pelo Gal. Cachapuz Medeiros, "que melhoraram o seu metabolismo basal", nunca teria pensado em sua vida "jagunça ser "símbolo, exemplo, orgulho nacional”, e comenta:

Eu, meu velho, não tomaria a iniciativa da divulgação. Essa é a minha alegria. Ter esse clima sem andar grudado no rabo do manto de ninguém. Sem tomar dinheiro emprestado. Sofrendo calado. Trabalhando sempre. Quero, pois, que V. saiba desses júbilos como conhece as horas tristes (CC, 23-X-1970, Id. Ibidem, p. 16-17).

Percebe-se, a partir desta primeira investida na epistolografia cascudeana enviada a Thaville, que a correspondência é um texto por definição destinado ao outro, que ajuda o individuo a aperfeiçoar-se, estimulando tanto o destinatário quanto o remetente a avaliarem cuidadosamente suas vidas cotidianas, e que também auxilia na avaliação do que se passa na alma e no corpo do sujeito que escreve e do que lê (IONTA, 2011, p. 94). Como se vê, são registros de constante estímulo, confidência, brincadeiras e esforço na dedicação dos projetos bibliográficos:

Parabéns pelo futuro livro. Não interrompa a tarefa. Ocupe-se para não preocupar-se. É o que faço aos 72... Exemplo de labor desinteressado e limpo. Tal e qual o Thaville. Retrato fica prometido. É uma vergonha mas não tenho reprodução da minha lindeza. O Comendador Papai-Noel merece a penitência da minha cara imóvel (CC, 5-XI-1970, apud, LEMOS, p. 18).

Na modernidade ocidental, a correspondência tingida por reflexão, introspecção, interioridade e intimidade, tensiona as fronteiras exibição/contenção, presença/ausência, proximidade/distância, fala/escrita, realidade/ficção, dentro/fora. Os paradoxos das cartas são correlatos dos modos de produção de subjetividade do indivíduo moderno. Nesse sentido, elas são fontes fecundas para problematizarmos a produção de subjetividades nas sociedades intimistas e para apontarmos a fragilidade do eu moderno, 
dotado de coerência e unidade. Além disso, a gramática da escrita epistolar e sua peculiaridade permitem capturar instantes fugidios, processos de metamorfose pessoal, momentos em que é possível visualizar vetores que conjugam simultaneamente movimentos de desprendimentos de si e auto-elaboração, realizados no espaço intersubjetivo da escrita epistolar e da amizade (IONTA, 2011, p. 94):

A vida que vivemos, Thaville, é um tanto feita por nós. O ambiente depende do nosso esforço teimoso, eliminando o desagradávelcontemporâneo e fazendo permanecer a ternura com que recordamos uma existência limpa, simples, feliz, sem vôos e sem quedas. É quanto nós dois realizamos. Tenho piedade dos que se acomodam nos fogareiros, dizendo-os poltronas... As alegrias espontâneas, humildes e naturais, são as únicas legítimas. As outras são publicidade de vagalume promovido a farol de navegadores (CC, 27-VIII-1971, apud, LEMOS, 1972, p. 31).

Cumpre reafirmar que as correspondências são documentos profícuos para problematizar a subjetividade, não porque elas oferecem o "eu" autêntico das personagens, mas por permitirem apreender os indivíduos em sua construção móvel, fluída e nômade; os valores aos quais se recorre para avaliar suas ações e seus pensamentos; as relações que as pessoas estabelecem consigo mesmas e com o destinatário amigo, exibindo dois aspectos importantes para os estudos da escrita de si: o caráter intersubjetivo da produção da subjetividade e o estatuto ético estético da fabricação de "si" mesmo (IONTA, 2011, p.99):

Está na cara ${ }^{15}$, evidentemente, que suas cartas e bilhetes são indispensáveis à minha solidão, povoada de visitas e solicitações. Tenho aqui nove cartas solicitando informações que tomariam meses. Nenhum pensou no trabalho duplicado que deseja receber, imediato, jubiloso, de um velho de 74 anos. Lógico que não poderei atender a todos. Sempre respondo suas afetuosas cartas quando tenho a respiração regular e não ofegante (CC, 1-IX-1972, apud, LEMOS, 1972, p. 56-57).

Neste aspecto, o tema da verdade como sinceridade, como o ponto de vista e de vivência do autor do documento foi situado e discutido de maneira contundente. Isso

\footnotetext{
${ }^{15}$ Grifos do original.
} 
porque a escrita de si assume a subjetividade de seu autor como dimensão intrigante de sua linguagem, construindo sobre ela a "sua" verdade. Ou seja, toda essa documentação de "produção do eu" é entendida como marcada pela busca de um "efeito de verdade" como a literatura tem designado -, que se exprime pela primeira pessoa do singular e que traduz a intenção de revelar dimensões "intimas e profundas" do indivíduo que assume sua autoria. Um tipo de texto em que a narrativa se faz de forma introspectiva, de maneira que nessa subjetividade se possa assentar sua autoridade, sua legitimidade como "prova". Assim, a autenticidade da escrita de si torna-se inseparável de sua singularidade. O que passa a importar para o historiador é exatamente a ótica assumida pelo registro e como seu autor a expressa. Isto é, o documento não trata de "dizer o que houve", mas de dizer o que o autor diz que viu, sentiu e experimentou, respectivamente, em relação a um acontecimento (GOMES, 2004, p.14-15).

Um elemento importante encontrado nessa correspondência é o refluxo de ideias e dos temas discutidos em sua rede de sociabilidade. Uma carta escrita no dia quatorze de novembro de 1970 diz respeito ao centenário natalício de Auta de Souza ${ }^{16}$, que ocorreria em 1976. O assunto entra em pauta, devido ao questionamento de Thaville sobre a existência de alguma edição de Horto, livro que à época estava esgotado. Cascudo acreditava que se fosse vivo em 1976, não seria encarregado da reedição, embora biógrafo de Auta e sabedor de todos os originais, "havia gente mais esperta na sabedoria" (CC, 14-XI-1970, apud, LEMOS, 1972, p. 19).

Não reeditou como também não discursou na solenidade organizada por Onofre Lopes ${ }^{17}$ em época vindoura; "resistindo ao pranto e ranger de dentes para não rodar até a próxima Macaíba na manhã de 12 de setembro" (CC, 31-VIII-1976, apud, SILVA, 2005, p. 122), em carta de trinta de julho de 1976, dirigida a João Lyra Filho, Cascudo comentou:

\footnotetext{
${ }^{16}$ Auta de Souza (1876-1901), poetisa oitocentista nascida em Macaíba, Rio Grande do Norte, faleceu em Natal, vitimada pela tuberculose. Seu único livro, intitulado Horto, conta até agora com cinco edições. A primeira recebeu prefácio de Olavo Bilac. A segunda foi organizada e contou com uma importante nota do irmão Henrique Castriciano de Souza. A terceira trouxe prefácio de Alceu Amoroso Lima, grande representante da crítica católica do país. A quinta apresentou um estudo crítico reunindo vida e obra da poetisa, espécie de síntese da tese de doutorado de Ana Laudelina Ferreira Gomes (2000) (GOMES, 2009, p. 15-16).

${ }^{17}$ Onofre Lopes (1907-1984), médico e professor. Fundador e primeiro reitor da Universidade Federal do Rio Grande do Norte. Criador e primeiro diretor da Faculdade de Medicina da mesma universidade. No prefácio de Pequeno manual do doente Aprendiz (1969), Cascudo nos informa: "E não seria apenas o conhecimento do médico a razão convincente da amizade, mas as jornadas feitas através de comentários e deduções comuns, aproximativas, em horas de confidência e sublimação" (CASCUDO, 1969, p. 9).
} 
No próximo 12 de setembro ocorrerá o centenário de AUTA DE SOUZA. Não poderei bracejar em Macaíba, evocando a Poetisa incomparável, que sua Mamãe cantava em modinhas. Onofre Lopes, no guidão da Academia, decidiu, justíssima, realizar as homenagens na cidade onde AUTA nasceu e não dentro de uma sala em Natal, ante sonolentos assistentes. Creio que a 'sessão' será no Grupo Escolar Auta de Souza. Havia um jasmineiro imenso e lindo que Auta plantara e cuidara. Um técnico assassinou o jasmineiro. Viva o progresso! Só pensando em nome feio... (CC, 30-VII-1972, Id. Ibidem, p. 120).

Nesta epistolografia, percebe-se que um dos primeiros livros enviados ao amigo foi Vida Breve de Auta de Souza (2008b), por isso, o interesse em comunicar sobre o centenário da poetisa. Quando do envio da obra, em carta de trinta e um de maio de 1970, o remetente esperava que ao ler o livro, Lyra Filho sentisse

\begin{abstract}
o clima emocional, tão diverso do interesse literário na evocação do carinho e solidarismo lírico. A família guardava ciumento segredo dos amores de Auta, o Dalias tornado Horto. Felizmente Eloy de Souza ${ }^{18}$ compreendeu e louvou, que eu fizesse com amor o que fatalmente seria feito com curiosidade e sensacionalismo erotico da falsa psicanálise (CC, 31-V-1970, apud, CASCUDO, 2005b, p. 51).
\end{abstract}

Em Vida Breve de Auta de Souza (2008b), Cascudo narrou que no mês de janeiro de 1943 esteve em Macaíba, Rio Grande do Norte, e visitou na Matriz o jazigo da família de Eloy Castriciano de Souza. Apenas essa indicação. Ali estavam os ossos dos antepassados "confusos, irmanados, dispersos, na comunidade material da morte" com os da poetisa. Entristeceu-se com o destino de Auta de Souza, negar-lhe um túmulo, um "doce abrigo", para o qual escrevera lápide no soneto "Ao pé do túmulo"19. Publicou em A República, de 23 de fevereiro de 1943, na sua secção Acta Diurna, uma crônica, reclamando, "Um túmulo para Auta de Souza". Crônica "cheia de engano nas datas e omissões, mas certa quanto ao sentido do apelo espontâneo e sincero". O

\footnotetext{
${ }^{18}$ Eloy de Souza (1873-1958), norte-rio-grandense, advogado, jornalista e político. Irmão mais velho de Auta de Souza e Henrique Castriciano. Como parlamentar, destacou-se na busca de soluções para o flagelo das secas. Sobre esse tema, pronunciou discursos, conferências e publicou inúmeros trabalhos. Ainda como parlamentar, atuou intensamente visando à erradicação de problemas econômicos e sociais do Rio Grande do Norte. Também colaborou nos periódicos natalenses, mas tratando de crítica literária e dos temas envoltos com o seu engajamento político (CASCUDO, 2005b, p. 39).

19 "Em pranto escrevam sobre a minha lousa: 'Longe da mágoa, enfim, no Céu repousa/ Quem sofreu muito e quem amou demais"”. Cf. (SOUZA, 2009, p. 207).
} 
resultado disto foi que, nos mesmos vinte e três de fevereiro, recebeu carta de Henrique Castriciano ${ }^{20}$, discordando formalmente de sua sugestão: "Auta tinha o túmulo que pedira e nunca outro" (CASCUDO, 2008b, p. 117-119).

Em resposta ao amigo e irmão da poetisa, Cascudo questionou o porquê não seria permitido ao Rio Grande do Norte mostrar a sepultura de sua maior poetisa? Quem explicaria, no futuro, a história do seu pedido e a serenidade da oposição fraterna? Finalizando a missiva no seguinte tom:

Auta lhe pertence. Ela e o túmulo da família. O nada da vida não explicará jamais Horto nem Aboio. Os criadores desses ritmos acreditaram vencer a morte, ultrapassando os limites escuros de um cemitério.

Enfim, meu caro H. Castriciano, tenho uma forma e outro processo de admirar. Não me permite que seja realizado. Faça-se a sua vontade e não a minha (Id. Ibidem, p. 122).

Retomando a publicação Mensagens de Câmara Cascudo e Cosme Lemos de Thadeu Villar de Lemos, e estabelecendo um paralelo, com passagens da epistolografia enviada a João Lyra Filho e Vida Breve de Auta de Souza, podemos afirmar que um dos principais usos da correspondência de escritores é o de servir comumente para acompanhar os diversos estados de criação de uma obra particular, ou a divulgação e circulação de sua obra, seguida de sua recepção pela crítica (que a carta comenta) e, enfim, o seu lento e inexorável esvanecimento nas águas turvas da memória (da qual a série de cartas pode se tornar o doloroso testemunho). Ou seja, as cartas sempre foram resguardadas como preciosos arquivos da criação (DIAZ, 2007, p. 123).

Neste sentido, podemos acompanhar na obra em questão rastros da circulação da obra de Cascudo durante o respectivo período em análise. Em carta de sete de junho de 1971, Cascudo informa sobre o lançamento em Natal do livro Sociologia do Açúcar. (CC, 7-VI-1971, apud, LEMOS, 1972, p. 23). Seguia trabalhando nas suas

\footnotetext{
${ }^{20}$ Henrique Castriciano (1874-1947) é reconhecido como o mais importante intelectual potiguar do começo do século XX. Um verdadeiro polígrafo, aprimorou o seu talento produzindo textos para o jornal $A^{\prime}$ República e, desde então, produziu poesia, ensaio, discursos, drama, ficção, artigos, crítica, textos pedagógicos, conferências e até relatórios administrativos. Foi interlocutor de intelectuais como Olavo Bilac, Coelho Neto, Afrânio Peixoto e outros. A partir da fundação da Liga de ensino (1914) e conforme modelo por ele trazido da Suíça, foi criada a Escola Doméstica de Natal (SANTOS, 2009, p. 211; CASCUDO, 2005b, p. 37).
} 
reminiscências de professor. Inteiramente fora do mundo e de suas ventanias poeirentas 21 (CC, 15-VI-1971, Id. Ibidem, p. 24).

Em carta de vinte e três de junho de 1971, o folclorista comenta sobre um projeto que não logrou êxito, seria um livro para 1972, uma Antologia de Fantasmas! Neste projeto, ele iria agenciar um depoimento de cada Estado, original, contemporâneo, inédito, sobre os fantasmas legítimos e não nascidos do "quengo jornalístico", fonte fecunda de imaginações:

o título é uma delícia, terá 999999 assuntos tratáveis semanais e eu ainda ia catucá-lo para mais um. Seria livro para 1972. Uma ANTOLOGIA DE FANTASMAS! (...) Essa ANTOLOGIA agenciava um depoimento de cada Estado, original, contemporâneo, inédito, sobre os fantasmas legítimos e não nascidos do quengo jornalístico, fonte fecunda de maginações. Volume precioso e de que carece a bibliografia nacional, mastigadora das mesmas imitações, mudando os molhos de sangue, esperma e suor (CC. 23-VI-1971, Id. Ibidem, p. 2425).

Comenta ao amigo Thaville, ainda, sobre ter ouvido o boato do lançamento em São Paulo, de outro livro seu, Tradição Ciência do Povo, embora ainda não tivesse visto esse seu "filhinho mais moço (desejava) a quem Deus ajude a andar e a ser simpatizado" (CC, 23-VI-1971, Id. Ibidem, p. 25).

Nas últimas cartas do ano de 1972, encontramos uma, a de vinte de março, Thaville pede para o folclorista encaminhar um exemplar de Alma Patrícia. No entanto, este foi um dos poucos pedidos do amigo que não pôde realizar; tendo em vista que “desapareceu nos cupins da nossa saudosa Vila Cascudo". Iria ver se descobria algum remanescente do Histórias que o tempo leva... Que se encontrava também esgotado. Informa por fim, do projeto da segunda edição de Canto de Muro. Comenta ao amigo que "graças a Deus, seria revista e diminuída; retirando o derradeiro capítulo, longo,

\footnotetext{
${ }^{21}$ Trata-se do livro Ontem, escrito em 1972, a obra remete às memórias de Cascudo em meio a sua vida docente iniciada em 1928 no Atheneu Norte-Rio-Grandense e concluída na Faculdade de Direito da UFRN em 1966. Mas que continuava falando aos rapazes e moças que enchiam a sua salinha de livros, ouvindo a voz que ainda não se apagara. Em suas palavras: "Todos os assuntos aqui reunidos rumam complementar a paisagem em que vivi e vivo" (CASCUDO, 1998c, p. 24). Em carta de trinta e um de maio de 1971, dirigida a João Lyra Filho, Cascudo já anunciava o projeto: "Estou, por sugestão da Universidade sob a égide de espirito-de-porco, batendo registo da minha 'experiencia, mensagem e missão' como professor. Episódios, figuras, anedotas, pedagogia, didática, apoio, oposição, enfim, 50 anos de laboriosa inutilidade jubilosa" (CC, 31-V-1972, apud, CASCUDO, 2005b, p. 51).
} 
erudito e pedante como peru de roda" (CC, 20-III-1972, Id. Ibidem, p. 50). O gênero epistolar como "arquivo da criação" é um espaço onde se encontram fixadas a gênese e as diversas etapas de elaboração de uma obra artística, desde o embrião do projeto até o debate sobre a recepção crítica favorecendo a sua eventual reelaboração. A carta, nesse sentido, ocupa o estatuto de crônica de obra de arte. A crítica genética, ao considerar a epistolografia um "canteiro de obras" ou um "ateliêe", busca descortinar a trama da invenção, o desenho de um ideal estético, quando examina as faces do processo da criação (MORAES, 2007b, p. 30).

2.4. "Como tenho a doutrina de transmitir as noticias jasmins e esquecer as xiquexique, levo essas às suas futuramente venerandas orelhas": cartas de Cascudo a João Lyra Filho

\footnotetext{
Pobre, sem dívidas, sem nadíssima solicitar, preciso ocupar-me para não preocupar-me (CC, 29-III-1972, apud, CASCUDO, 2005b, p.64).
}

Enfim, João-querido, ocupação para as minhas horas que não se aposentaram como eu (CC, 30-XII-1972, Id. Ibidem, p. 79).

Os documentos analisados a partir de agora compõem a obra Flama Serena Cartas de Luís da Câmara Cascudo a João Lyra Filho (2005b); já foram catalogados, anotados e publicados resumidamente em 2000, na obra Jasmins do Sobradinho, organizados por Roberto da Silva. Conforme registrou na publicação precedente, localizou-os no arquivo do escritor João Lyra Filho, no Rio de Janeiro, em 1998. O organizador tomou conhecimento de sua existência por intermédio do destinatário das missivas cascudeanas, a quem sugeriu sua divulgação. Cronologicamente, o primeiro destes documentos é uma carta sem indicação de local e data; mas, a partir de alguns dados nela contidos, depreende-se que teria sido elaborada em 1969. Considerando a intensa produção intelectual desses escritores, bem como o apreço de ambos pela epistolografia, parece incompreensível que a correspondência entre os mesmos se tenha 
iniciado tão tardiamente: Cascudo estava com 71 anos e João Lyra Filho com 63 (SILVA, 2005, p. 17; 25).

Um fato biográfico de Cascudo não deve aqui ser negligenciado: sua viagem ao Rio, naquele ano. Ali, esteve de dez a vinte e sete de janeiro e esse assunto foi amplamente anunciado pela imprensa carioca. Reencontrou familiares, velhos amigos e confrades. Ao Museu da Imagem e do Som, deu um longo depoimento; a Academia Brasileira de Letras, o Instituto Nacional do Livro, o centro Norte-Rio-grandense do Rio de Janeiro e a Campanha de Defesa do Folclore Brasileiro prestaram-lhe homenagens, distintamente. É possível que entre Cascudo e João Lyra Filho, então Reitor da Universidade do Estado da Guanabara, tenha havido algum contato, embora o missivista não tenha a ele se referido em Na Ronda do Tempo (Diário de 1969) e; talvez, a partir daí, uma amizade que vinha de longe, nascida com seus ancestrais ${ }^{22}$, se tenha estreitado, e os dois escritores tenham passado a cartear-se (CASCUDO, 1998b, p. 3867; SILVA, 2005, p. 24).

É fato por demais conhecido o hábito de Cascudo, durante a realização de suas pesquisas, de solicitar a amigos, no Brasil e noutros países, materiais que as subsidiassem. Ele, conforme afirmava, "derramava cartas perguntadeiras" acerca de determinados assuntos, pedia livros, cópias de documentos, fotografias, indagava sobre fatos e datas, insistindo nas mesmas questões a um ou a vários informantes, para poder confrontar as respostas e somente utilizá-las em suas pesquisas quando estava seguro de sua exatidão. João Lyra Filho, como é fácil de constatarmos aqui, foi um colaborador em quem o autor do Dicionário do folclore brasileiro confiava plenamente (SILVA, 2005, p. 27):

Ego sto ad ostium et pulso! Estou à porta, e bato, como se lê no Apocalipse. Trabalho como V. tem a generosidade de dizer, na base

\footnotetext{
${ }^{22} \mathrm{Na}$ carta em questão, podemos ver: (...) "Sou casado a 40 anos, com uma Dahlia, a filha mais nova (e mais bonita) do Dr. Teotonio Freire, desembargador, Juiz Federal. Da amisade de LUIS LYRA, o melhor conservador da Cidade, e das Lyras, Dondon, Alice e Adelia, amigas de minha Mãe" (...) (CC, s/d, s/l, apud, CASCUDO, 2005b p. 35). Diz respeito, ao Des. Luís Tavares de Lyra, que foi tio de João Lyra Filho, e influência decisiva em sua formação intelectual, bem como em sua conduta na administração pública (Id. Ibidem, p. 175). Tavares de Lyra sucedeu o governo de Pedro Velho, não chegou a completar o mandato para assumir pastas ministeriais no Governo de Afonso Pena, depois no de Venceslau Brás. Era também um intelectual, possuindo uma vocação extraordinária para historiador, além de se dedicar aos estudos sociológicos e econômicos sobre o estado do Rio Grande do Norte (SANTOS, 2009, p. 99). Em outras cartas, de 11-II-1972 e 20-III-1972; Cascudo fala sobre o centenário de Tavares de Lyra, além de disponibilizar para apreciação de João Lyra Filho, o artigo LYRA ESTADUAL, que no mesmo ano irá compor com outros textos o seu quarto livro de memória Ontem (1998c), Cf. (CASCUDO, 1998c, p. 185186).
} 
da erudição, no plano documental exagerado, extenso, possivelmente universal. Esses intuitos realizáveis em Natal, João Pessoa, Aracaju, Maceió, são tentativas de mariposa voar para Sirius, convencida de aterrissage fortuita. Tradução: - vêz por outra estou catucando uma vítima no Rio de Janeiro, solicitando informação, copia de algumas páginas, fotos. Tudo isso suando de acanhamento ou de cinismo... Resta-me a V. fonte onde levo minha bilha provinciana e vazia. Não seria possível obter uma copia datilografada? Foto já meus olhos não distinguem bem. Não se constranja, não sendo possível (CC, 26-III1970, apud, CASCUDO, 2005b, p. 41).

Vista sob a mesma ótica atribuída às cartas enviadas a Thaville, a correspondência remetida a João Lyra Filho também se coloca como espaço de arquivos da criação e crítica genética. Nela, são revelados projetos de trabalho abandonados como o de escrever um Livro negro da cultura popular brasileira:

Imagine que em 1948, aos 50 anos joviais, lembrei-me escrever um Livro negro da cultura popular brasileira no jeito da grave KRIPTÁDIA alemã mas recusei assombrado com a pacholice e deboche intelectual, incapaz de compreender coisas serias no nível erótico (CC, 29-III-1972, Id. Ibidem, p. 63).

Temos neste ponto um aspecto de sua rotineira vida de professor e pesquisador, estando sempre às voltas com a máquina de escrever procurava "ocupar-se para não preocupar-se" porque suas horas não tinham se aposentado e queria tarefas, comenta que não pensava em publicação e sim em fazer livros. E brinca com Lyra Filho, dizendo que "o destino do mamoeiro é produzir mamão. Não importa que a fruta apodreça ao pé da árvore ou emigre a semente no papo da sabiá. Preciso continuar fora do fandango, vendo passar o maracatu" (CC, 29-V-1970, Id. Ibidem, p. 45).

Nesta correspondência a João Lyra Filho, vemos que do final de 1976 ao inicio de 1977, temos menção a mais um projeto inacabado. Trata-se de um estudo sobre superstição cujo título irá variar de Antologia da superstição no Brasil para Geografia da superstição no Brasil. Num total de oito cartas, um cartão e um telegrama enviados ao amigo, Cascudo irá convencê-lo de contribuir com o envio de um artigo para compor a obra, chega inclusive a agradecer a contribuição de Lyra Filho, todavia, a obra não chegou a ser publicada. 
Este projeto começa a ser anunciado em carta de quinze de outubro de 1976; nesta, volta a comentar sobre a necessidade de sempre continuar pesquisando, por acreditar que a "indolência é uma enfermidade irritante jamais dolce". Depois de muita promessa ao Divino Espirito Santo, ficara atuado e estava "trabucando" um cartapácio Antologia da superstição no Brasil. Iria explorar o que tinha feito ${ }^{23}$ e o que os outros iriam fazer sacrificando em louvor da deusa Amizade. Neste projeto, excluiria as lendas religiosas e os mitos de assombro, com entidades sobrenaturais de forma humana ou bestial. Interessava-lhe nesta ocasião a superstição moente, comum, corrente, geral e pessoal. Processo instintivo secular de atrair o bem e evitar o mal, decifrar os bons e os maus agouros, etc. Feita a apresentação da proposta, estende o convite:

Sonho de várias noites de verão é conseguir seduzir JOÃO LYRA FILHO para aceitar a Capitania da Paraíba, fixando n'algumas folhas de papel as SUPERSTIÇÕES DA PARAÍBA, sem muito cuidar de explicações, analises e o mais que dos autos constem. Seria uma garantia de limpidez, segurança, honestidade testemunhal, o seu depoimento, ansiosamente solicitado. Dilação probatória até finais de janeiro próximo. Então? Diga que sim e a noite iluminar-se-á. Ficarei álacre e buliçoso como pinto em beira de cerca (CC, 15-X-1976, Id. Ibidem, p. 128-129).

Em carta de vinte de outubro de 1976, Cascudo menciona que depois de enviada a carta anterior, ficou "mastigando outra missão", mais importante, rara e sugestiva que tratar das superstições paraibanas, e de enviar algumas páginas inéditas que mais valorizariam o projeto:

SUPERSTIÇÃO NO FUTEBOL ${ }^{24}$ ! Toque reunir ás reminiscencias e bata-língua com os antigos craques que já não pisam no gramado. Em prazo de três meses, Vossa Magnificiencia teria 'cancha' para revelações maravilhosas. Assunto virgem, donzelil, cabeçudo. V. faria as superstições paraibanas em duas semanas, máximas teria campo para desenvolver jogo na Superstição no Futebol que toda gente, 99\%,

\footnotetext{
23 Para um aprofundamento do tema superstição na obra de Câmara Cascudo, Cf. (LIMA, 2003; SIQUEIRA, 2003; OLIVEIRA, 2009).

${ }^{24}$ Cascudo, sugeriu a temática, devido ao fato de João Lyra Filho ter sido presidente do Clube Botafogo de Futebol e Regatas, e do Conselho Nacional de Desportos, além de autor da maioria dos textos da legislação desportiva brasileira, tendo também institucionalizado a Justiça Desportiva no país, através de preceitos normativos do tempo em que presidiu o CND (CASCUDO, 2005b, p. 176).
} 
ignora como o caminho do Paraíso. Se V. acha não ter costado para agoentar as duas caçambas, vá arriando uma, e corra ao FUTEBOL onde é sem suplente. Fique com as duas, porque Superstição na Paraiba é carga maneira para seus ombros robustos e afeitos ao pêsopesado. Responda, criatura de Nossa Senhora das Neves. Nem lhe digo da minha alvoroçada alegria (CC, 20-X-1976, Id. Ibidem, p. 130).

No dia seis de novembro de 1976, temos um cartão de visita, escrito à mão, sem assinatura, e uma carta que tratam, além de outros assuntos, da tentativa de convencimento de Lyra Filho a participar do processo editorial em questão. Constatamos que Cascudo contaria até o momento com 14 "promessas" de colaboração, embora não aponte quem seriam os demais nomes; ele ainda espera contar com mais 7 amigos, um deles, sendo, portanto o destinatário em questão ${ }^{25}$. Cascudo, na busca de convencer o amigo, informa que tendo o original de Superstição do futebol, o livro seria um "tiro na mosca", uma grande contribuição, espécie de "Arvore do Natal ou presente dos Reis Magos" (CC, 6-XI-1976, Id. Ibidem, p. 132-133). Em carta enviada no dia onze de dezembro do mesmo ano, percebe-se que ele conseguiu convencer João Lyra Filho a participar (CC, 11-XII-1976, Id. Ibidem, p. 135). Como podemos perceber, o projeto de publicação Geografia da superstição encheu-lhe a alma de preocupações deleitosas, junto ao amigo João Lyra Filho. "Esta foi a solução para não ver a 'noite' lenta, sinistra, inafastavel dos mortais" (CC, 16-XII-1976, Id. Ibidem, p. 137).

Afora esses projetos não concluídos, temos, nas cartas enviadas a João Lyra Filho, a informação de algumas das obras publicadas durante a época que a respectiva epistolografia cobre. Em trinta e um de maio de 1971, informava que "60 anos de

\footnotetext{
${ }^{25}$ Na próxima secção, veremos que o convite para participação neste projeto, também foi feito a Oswaldo Lamartine de Faria. Cf. (LAMARTINE DE FARIA, 2005, p. 38-40). Embora não seja objeto de nossa análise, registro aqui que o convite foi estendido a Raimundo Nonato, encontra-se catalogado na obra Apostila do Afeto: Câmara Cascudo (1986) que fora organizada por Raimundo Soares de Brito. São quatro os registros presentes: (...) 'aproveitando o rabo de 1976 e o primeiro semestre vindouro, fazer uma ANTOLOGIA DA SUPERSTIÇÃO NO BRASIL. (...) Entrego-lhe o Rio Grande do Norte, sertão, agreste e litoral, para fixar, nas suas inimitáveis reminiscências, as nossas superstições mais típicas'. (...) (CC, 13-X-1976, Apud, BRITO, 1986, p. 52); (...) 'V. tem três meses para pensar, ler, perguntar. Pensar, sinônimo de espremer as lembranças velhas. Superstição, percepção dos avisos misteriosos anunciando o Bem ou o Mal'. (...) (CC, 26-X-1976, Id. Ibidem, p. 54); 'Lembre-se que o Rio Grande do Norte figurará no meu cartapácio sob sua assinatura, devotamento e bondade de olho d'água há cem anos passados. Vá metendo os peitos na tarefa'. (...) (CC, 30-X-1976, Id. Ibidem, p. 56); (...) 'NONATO, Estrondo no Pé da Serra. Nossa amizade, pela intensidade e fundura, já não mais comporta constrangimentos e silêncios opressivos como peido incausado. V. abra dos peitos e diga se tem bagagem e disposição para fazer umas 10 páginas com a SUPERSTIÇÃO NO RIO GRANDE DO NORTE'. (...) (CC, 6-XI-1976, Id. Ibidem, p. 57).
} 
paladar sacarino e convivência bagaceiral”, Sociologia do Açúcar já estava no prelo (CC, 31-V-1971, Id. Ibidem, p. 51). Aponta em carta de vinte e nove de março de 1972 que, para a elaboração da respectiva obra, contou com o conhecimento intimo de exescravos da bagaceira. Os mesmos que já o tinham auxiliado com informações para elaboração do capítulo "Comida de Escravos" na História da Alimentação no Brasil. Como estava de "guela aberta, [confidenciou] dizendo que a Fundação José Augusto publicará um livro lento e valente, Prelúdio e Fuga do Real", pede ao amigo que sente e que continuasse a ler. Havia entregado em novembro "um cartapácio de 445 páginas sobre Uma História da Assembléia Legislativa do Rio Grande do Norte". Finaliza a missiva dizendo que respondia imediatamente, porque ia "ficar uns dias debaixo d'água com um ensaio sobre a Independência no Rio Grande do Norte, convite do Governo que aceitei hoje e que V. é o confidente e vitima resignada" (CC, 29-III-1972, Iid. Ibidem, p. $64)$.

Confessou ao velho amigo, em carta de dez de janeiro de 1972, que estava na idade e fase de maturação tranquila, onde os anos vividos possibilitavam esforço com os músculos pessoais. Pois, a elaboração de um livro novo desarrumava a mobília interior, a disposição da nova paisagem intima. Sendo esta resultado de raciocínio velho, experiência, prova intuição, onde os livros consultados servem só para fundamentar o ponto de vista. Tinha pavor dos livros feitos de camadas eruditas sobrepostas, sem o cimento da ideia individual e original (CC, 10-I-1972, Id. Ibidem, p. 82). É o que se percebe quando na respectiva correspondência faz menção aos textos clássicos e contemporâneos na correspondência em questão.

Muitos dos documentos analisados trazem a afirmação do ilimitado amor de Cascudo ao trabalho. Por isso, afirmava: "Que alegria nos dá o trabalho! Por isso pedirei a Deus uma tarefa no Paraíso, livrando-me do repouso eterno..." (CC, 14-XII1973, Id. Ibidem, p. 99). Os raros momentos de abatimento do etnógrafo, um homem cujo bom-humor era notável em suas cartas, são resultantes, justamente, da precariedade de sua saúde, que impedia de prosseguir o incansável labor:

A saúde tem sido combustível apenas suficiente ao trafego comum dentro de casa. Equilibro a omissão fazendo planos irrealizáveis mas uteis para utilizar o saldo imaginativo, teimoso em sublimação inconsistente. (...) A deliberada ignorância livra-me dos assombros jornalísticos, reforçando-me no tempo em que percebia confidencias de grilos e conversas de largatixas concordantes. (...) De papo em 
papo, a galinha enche o grão. Pretexto de matar o tempo enquanto ele não nos sepulta (CC, 21-I-1975, Id. Ibidem, p. 109).

Numa das últimas cartas enviadas a João Lyra Filho, escrita em doze de maio de 1979, comenta que em dezembro de 1978, comemorou-se a data dos seus 80 anos. Em vinte e um de abril de 1979, festejaram suas bodas de ouro, em nove de maio passou o dia pensando que há 80 anos, fora batizado pelo Padre João Maria ${ }^{26}$, canonizado pela cidade. Expõe que uma pilha de emoções fazia desmoronar seu equilíbrio orgânico. $\mathrm{O}$ antigo jorro epistolar estreitava-se a conta gotas. Os olhos anoiteciam, melancolicamente, já não deixava o sobradinho da Junqueira Aires, temeroso do transito. Findava a carta pedindo ao amigo que maldissesse as enfermidades que lhe assaltavam, pois se sentia humilhado por não responder cartas e agradecer livros na presteza dos tempos idos. Já não mais escrevia novidades, apenas "temperava segundas edições”. Serenamente, “descia a ladeira oitentona” (CC, 12-V-1979, Id. Ibidem, p. 161).

As cartas, como documentos/monumentos, não são apenas objetos-lembranças dos elos entre amigos; são também documentos literários dotados de uma escritura peculiar. Trata-se de um gênero narrativo que guarda uma escrita de si, do sujeito e seu texto, bem como sua interação com o outro (IONTA, 2013, p. 166). A carta, texto por definição destinado a outrem, dá também lugar ao exercício pessoal, pois, quando escrevemos, lemos o que vamos escrever exatamente do mesmo modo como ao dizermos qualquer coisa, ouvimos o que estamos a dizer. A carta enviada atua, em virtude do próprio gesto da escrita, sobre aquele que envia, assim como atua, pela leitura e a releitura, sobre aquele que a recebe.

A carta que é enviada para auxiliar seu correspondente - aconselhá-lo, exortálo, admoestá-lo, consolá-lo - constitui, para o escritor, uma maneira de se treinar: tal como os soldados se exercitam no manejo das armas em tempos de paz, também os conselhos que são dados aos outros na medida da urgência da situação constituem uma maneira de se preparar a si próprio para eventualidade semelhante. É algo mais do que um adestramento de si próprio pela escrita, por intermédio dos conselhos e opiniões que se dão ao outro: ela constitui também uma forma de cada um se manifestar a si próprio e

\footnotetext{
${ }^{26}$ Pe. João Maria Cavalcanti de Brito (1848-1905), norte-rio-grandense. Ordenou-se no Ceára (1871). Foi vigário em algumas paróquias do interior e Natal, onde tomou posse da freguesia em 1881. Incansável, extremamente caridoso, foi considerado santo em vida pelos paroquianos. Seu busto em bronze, inaugurado na praça do seu nome, no centro de Natal em 1921, é lugar de devoção popular, onde se reza e se acendem velas votivas (CASCUDO, 2005b, p. 162).
} 
aos outros. A carta faz o escritor "presente" àquele a quem a dirige, escrever é, pois "mostrar-se", dar-se a ver, fazer aparecer o rosto próprio junto ao outro. E deve-se entender por tal que a carta é simultaneamente um olhar que se volve para o destinatário (por meio da missiva que recebe, ele se sente olhado) e uma maneira de o remetente se oferecer a seu olhar pelo que de si mesmo diz (FOUCAULT, 1992, p. 145-150).

\section{5. "Um bom abraço deste seu velho": cartas de Cascudo para Oswald Lamartine}

Preciso ocupar-me para não preocupar-me. Não tenho Inveja e menor recalque justamente por viver com o focinho atolado nas minhas laboriosas inutilidades. Não atino com o santo do dia nem pelo nome do vigário. Encanto, Oswaldinho!

(CC, 10-I-1972, apud, LAMARTINE DE FARIA, 2005, p. 20).

Cartas fixam experiências. O tempo, sempre inevitável, desgasta - ou fortalece relações, afetos, amizades. As cartas revelam o quanto se esteve seduzido, cativado, encantado - ou não. No caso de Oswaldo Lamartine e Luís da Câmara Cascudo, a sedução é mútua. Ambos se queriam, necessitavam-se. Cascudo, sempre urbano, estava atento ao "registrador das coisas do sertão" em que Oswaldo se tornara - e o incentivava a seguir seu caminho. Oswaldo, mesmo já morando no Rio de Janeiro, metrópole e capital cultural do país, precisava da sabedoria primordial do mestre (CASTRO, 2015, p. 104).

No texto que abre o livro, Oswaldo rememora a amizade da sua família com a família de Cascudo e as visitas do extrovertido Francisco Cascudo (1863-1935) - "era um conversador de encher a sala" - e do seu filho Câmara Cascudo a seu pai, Juvenal Lamartine, na casa da rua Trairí, 558: "Mais ou menos por esse tempo o filho dele, Cascudinho, também andava sempre lá por casa numa inquisição de perguntar a meu pai coisa do sertão velho". Estas são lembranças de quem à época "era ainda um menino para quem o mundo se resumiu num quintal de mangueiras, futebol de bola-de-meia e batalhas aéreas de arraias de rabos faiscantes de rucegas, ali bem perto do Campo do Triângulo, onde hoje construíram o Ateneu”. Mesmo com os infortúnios que o destino reservou para os Lamartine nos anos de 1930 - "Meu pai desterrado, nossa casa depredada e eu, sem ter condições de estudar em Natal" -, a amizade entre as duas famílias permaneceu. A década de 1940 traz Oswaldo de volta ao Rio Grande do Norte - formado pela Escola Superior de Agricultura de Lavras, irá trabalhar na Fazenda 
Lagoa Nova, em Riachuelo - e ao convívio de Luís da Câmara Cascudo. A amizade de "Cascudinho" com Juvenal Lamartine se estenderá, incondicionalmente, ao filho Oswaldo (CASTRO, 2015, p. 106):

Por esse tempo, Luís da Câmara Cascudo, o então, Cascudinho, também continuava amigo de meu pai e de meu irmão Silvino, pediatra de seus filhos. Foi não foi, quando eu ia a Natal, dava as caras na casa dele. Visita de amizade e perguntação: eu, tentando inutilmente tapar os buracos maiores de minha ignorância, e ele querendo saber cada coisa do sertão, se ainda era assim ou assado ou como se fazia agora - cutucando, na faquinha-curta, minha curiosidade para o mundo onde vivia e não via (LAMARTINE DE FARIA, 2005, p. 13).

Maio de 1973, véspera do centenário de nascimento de Juvenal Lamartine, inspira Cascudo a rememorar o pai de Oswaldo. Em uma folha de papel timbrada com o seu nome completo e seu endereço, ele escreverá (CASTRO, 2015, p. 124):

Ultimamente tenho pensado muito em Juvenal Lamartine. Encontrei, num caderno, essa frase admiravel que me disse: - 'A tragédia do político é a confidencia de ternura ser julgada um cinismo!' Ninguem admite a sensibilidade no eleitoral. Tragédia, realmente. No livro de Zila Mamede sobre minha bibliografia, V. encontrará uma cronica em que comentei uma frase dele: - EU NÃO TEMO A MOCIDADE! Perdôê a vaidade da lembrança. Não sei quando foi. Logo depois da posse, numa festa publica. Tempos passados, Oswaldinho... (CC, 31 V-1973, apud, LAMARTINE DE FARIA, 2005, p. 31).

Nas crônicas da Acta diurna, do jornal A República, de sete de junho de 1928, é possível detectar o artigo "Eu não temo a mocidade", que, de acordo com Cascudo, foi a exclamação de Juvenal Lamartine ao discurso de Joaquim Ignácio. Juvenal, não temia a mocidade. Ao contrário, nela se revia e se orgulhava como os pais nos filhos, por que seria ela quem continuaria seu trabalho e suas ideias. Da mocidade, aproximava-se e a encorajava, estimulando-a. Nela, confiava porque suas ideias são votadas à grandeza da terra comum (CASCUDO, 1928, apud, FERREIRA, 2011, p. 74).

Nesta crônica, Juvenal Lamartine surge como um governante cujas qualidades excepcionais vão emergindo, uma a uma, no perfil traçado por Cascudo: "Um 
presidente que guia automóvel, viaja de avião, discute literatura, dirige politicamente a campanha do Feminismo Brasileiro é pouco parecido com as figuras hirtas e que quatrienalmente recebem dithirambos nos Estados" (Id. Ibidem, p. 74).

Juvenal Lamartine, assim, se torna quase uma metonímia da época. Ele galvanizava as energias emancipatórias que se manifestavam por todos os lados. Os sinais dessas energias podem ser pressentidos desde o início do século XX nas vozes que pediam o rompimento em relação a uma situação tradicional, ainda que essa situação nem sempre esteja definida com clareza, tampouco os meios para promovê-lo. Alguns chegavam a acreditar que a própria política, inspirada na pura racionalidade de princípios esclarecidos e métodos científicos, estava libertando do domínio viciado das vontades personalistas, que representavam ignorância e atraso; outros (mais exatamente, outras) divisavam, desde o início do século, os primeiros raios que pareciam anunciar a emancipação da mulher, consolidada, pelo menos em parte, por Juvenal Lamartine, como o seu apoio ao voto feminino (ARRAIS, 2005, p. 58-59).

Ler tal correspondência é imergir na riqueza do universo desses dois homens. Jamais saberemos se Câmara Cascudo aprovaria ter essas cartas publicadas e lidas por outros além do seu "Oswaldinho". Afinal, "A história de qualquer coisa é apenas o que podemos saber sobre esta coisa, jamais a totalidade. A lacuna é onipresente" (PENA, 2006, p. 76). Em alguns momentos, há uma sensação de estarmos nos apossando de algo que não nos pertence, mas em outros, a sensação é de estarmos em casa, no aconchego da nossa intimidade, lendo antigas cartas que falam sobre coisas que muito nos interessam e nos vitalizam. O que faremos com essas leituras é uma responsabilidade que temos com cada carta lida, pois “(...) toda vez que lemos um texto sobre o que já passou, estamos dando nova forma àquele acontecimento" (Id. Ibidem, p. 76). Portanto, esses escritos nos dizem coisas que não disseram a Oswaldo e vice-versa (CASTRO, 2015, p. 109).

Nesta última parte que se inicia, vemos a recorrência de aspectos discutidos nas passagens que versam sobre a correspondência de Thaville e Lyra Filho, ou seja, certo anseio frente ao envelhecimento, saúde e aposentadoria. Durante esse tempo, ainda vinha escrevendo e estudando com frequência, no entanto, não deve ter sido fácil imaginar que seu próprio corpo, outrora tão cheio de frescor e muitas vezes de sensações agradáveis, ficasse vagaroso, cansado e desajeitado (OLIVEIRA, 2009, p. 30$31)$. 
No ano de 1974, Câmara Cascudo, comentando sua miopia e surdez, revela as "vantagens" que elas proporcionam. Sempre ocupado para não se preocupar, percebe-se quanto Cascudo mostrava-se cético em relação aos jornais que noticiavam de forma equivocada sua perda de audição. Nessa mensagem, em que usa a imagem do menino que conserta brinquedo para se divertir Cascudo dá a senha para dizer o porquê de sua grandiosa e extensa obra (CASTRO, 2015, p.126 ):

Os jornais, amáveis nos audimetros, e mesmo uma TV sem assunto de futebol, informam que o velho professor está ouvindo muito mais do que grilo. Não posso andar de pandeiro na mão desmentindo. $\mathrm{O}$ remédio é morder a língua e suspeitar da honestidade funcional das progenitoras dos noticiaristas. Sigo trabalhando para entreter-me, como menino conserta brinquedo. Ocupado para livraR-me da preocupação. A surdez evita boato e a miopia, afastando jornais, garante o estado de inocência (CC, 13-IV-1974, apud, LAMARTINE DE FARIA, 2005, p. 34).

Sua condição de saúde, sempre complicada durante o período, fazia com que "ficasse com alergia à salinha de livros para não ver a pilha de cartas sem resposta e livros sem agradecimentos":

\footnotetext{
Estou com um desvio de circulação, entregue ás engrenagens do check-up, eletrocardiogramas, radioscopias toraxicas, medicação complicada sob a supervisão de minha mulher, doce e implacavel. Preguiça mental invencivel e uma indolencia total de burocrata conspicuo. Tudo parado. Alergía à salinha de livros para não ver a pilha de cartas sem resposta e livros sem agradecimentos...Barbaridade! Não posso deixar de responder ao abôio do sobrinho querido, ecoando nos taboleiros cariocas (CC, 10V-1975, Id. Ibidem, p. 35).
}

Por isso, sempre afirmava que precisava, por medida de higiene profilática, encher suas horas que não tinham se aposentado e pediam função realizadora; como a surdez lhe afastava da convivência, restava-lhe a alegria do trabalho silencioso e domiciliar: 
Preciso, por medida de higiene profilatica, encher minhas horas que não se aposentaram e pedem função realizadora. O desvio circulatório, alterando o matabolismo basal, já não permite sair do poleiro quanto maisviajar, pesquisar. A surdês afasta-me da convivencia. Resta a alegria do trabalho silencioso, domiciliar, como abelha sem asas ou sapo sem pernas (CC, 22-X-1976, Id. Ibidem, p. 38).

A necessidade de "ocupar-se para não preocupar-se" levou Cascudo a também convidar Lamartine a participar do "livro que estava trabucando", Geografia da superstição no Brasil, como já o fizera com João Lyra Filho. Cascudo, “de quenga na mão à porta do coração amigo pedindo colaboração", pois não poderia "construir Arca de Noé tendo unicamente Noé dentro da qual”:

Estou trabucando uma GEOGRAFIA DA SUPERSTIÇÃO NO BRASIL, indo de quenga na mão à porta do coração amigo pedindo colaboração, pois não poderei construir Arca de Noé tendo unicamente Noé dentro da qual. Venho entregar ao velho sobrinho afetuoso o ramo de pensar, ruminar lembrar e escrever umas folhas sobre a SUPERSTIÇÃO NO SERIDÓ, no SERTÃO, ou que outro nome haja. Entrega em fim de Janeiro de 1977. Topa? Nada de lendas religiosas ou mitos de assombração, lubisôme, burrinha, caipora, tarará, tarará, etc. Superstição de caçadores, pescadores de açudes e rios, comboeiros, almocreves, gente de mercado e feira, agricultores, etc, etc, etc,. Topa? Ficarei feliz tendo a V. por um companhero neste livreco limpo de invenção e mentira (CC, 22-X-1976, Id. Ibidem, p. 38-39).

Em carta de dezessete de novembro de 1976, devolvia as notas "gostosas sobre Supertições”. Informava a Lamartine que não ia querer lenha para fogueira, utilizando suas buscas e rebuscas, desejava um "artiguinho" de seis a oito páginas, assinado e entregue até janeiro de 1977, considerado por Cascudo como prazo suficiente "para pensar, espremer a memória, catucar os parceiros, perguntando ao outros":

Devolvo as notas gostosas sobre Superstições. Não vou querer lenha para fogueira, utilizando suas buscas e rebuscas. Quero, perdôe a intimativa de tio-velho, artiguinho seu, 6 a 8 páginas, assinado, entregue até Janeiro de 1977. Prazo suficiente para pensar, espremer a memória, catucar os parceiros, perguntando aos outros. Tá? Para não 
'dobrar os encantos' devolvo o 'material' que figurará no 'definitivo', convenientemente ajeitado no rumo do rasto. Não podia deixar a V. de banda, na hora em que arregimento os meus bandoleiros fieis. Saíu em Outubro o 'História dos nossos Gestos' em que 'labutei' seis anos. Edições Melhoramento, S. Paulo. Para não ver a Noite Imovel que vem vindo, meto os peitos noutra tarefa. Mudar de rojão é descanso ao caminhador (CC, 17-XI-1976, Id. Ibidem, p. 40).

Em carta de primeiro de fevereiro de 1977, é possível ver Cascudo pedindo a Oswaldo Lamartine que mandasse "quando poder, uma notinha bio-biliografia sobre V. mesmo, para o nosso SUPERSTIÇÃO apresentar seus colaboradores ao respeitavel público". Finaliza o assunto, comentando que o "livro cresce como vazante" (CC, 1-II1977, Id. Ibidem, p. 42). Na correspondência de Câmara Cascudo destinada a Oswaldo Lamartine, ainda é possível encontrar um último registro sobre o projeto deste livro, também comentado na correspondência enviada a João Lyra Filho; em carta despachada no dia três de março de 1978, Cascudo afirma que o livro Superstição no Brasil voou para o prelo:

SUPERSTIÇÃO NO BRASIL voôu para o prelo, quase completa, e no meio da catrevajem incluiu-se sua falação gostosa. O editor é o mesmo facínora da ANTOLOGIA DA ALIMENTAÇÃO NO BRASIL, prometendo o Cruzeiro do Sul mas não dá nem a Papacêia vespertina. Nada diz. Quero apenas que as minhas marrecas nadem. Açude ou lagôa. Milagre do Padre Ciço um escriba provinciano topar editor, espontâneo e amável como vendedor de sabão. Nem aprendi a procura-los, Oswaldinho! (CC, 3-III-1978, Id. Ibidem, p. 52)

Talvez por essa passagem, Marize Lima de Castro (2015), tenha afirmado, em sua tese que o respectivo projeto aqui comentado tenha sido "posteriormente publicado sob o título Superstição no Brasil (1985)". A autora afirma em nota que Câmara Cascudo já havia publicado, no ano de 1958, o livro Superstições e costumes: pesquisa e notas de etnografia brasileira, editado no Rio de Janeiro por Antunes \& Cia. Ltda, sendo uma edição comemorativa dos sessenta anos de idade e quarenta de escritor. (CASTRO, 2015, p. 128). Entretanto, tão pouco o livro Superstições e costumes tenha 
sido o único livro publicado por Cascudo sobre a temática ${ }^{27}$; como Superstição no Brasil trata-se da mesma proposta de Geografia da Superstição no Brasil, mesmo que esta informação esteja endossada pelo etnógrafo potiguar, na carta acima citada ${ }^{28}$.

O livro Superstição no Brasil abarca quase tudo o que foi escrito sobre o assunto por Luís da Câmara Cascudo. Reúne Anúbis e Outros Ensaios (1951), Superstições e Costumes (1958) e Religião no Povo (1974) ${ }^{29}$. É trabalho etnográfico, se entendermos a etnografia como o estudo de estabelecimento, modificações e vitalidade das culturas humanas, como a memória no tempo. Na realidade, são três livros elucidativos da cultura e mentalidade do povo brasileiro, apreendidas nos costumes que afloram no cotidiano (CASCUDO, 2001, p. 11; SIQUEIRA, 2003, p. 270).

$\mathrm{Na}$ quarta edição do respectivo livro, Cascudo, afirmou que o critério não era apenas registrar em livro, "mas a tentativa de elucidação das origens. A imaginação não colaborou, mas os exemplos foram lidos ou vividos no ambiente em que viveu o autor" (CASCUDO, 2001, p. 11); podemos encontrar também uma carta de Cascudo, destinada a Pedro Paulo Moreira (editor da obra), carinhosamente chamado de Barão de Itatiaia. Nela, podemos ver Cascudo, em 1984, um ano antes da primeira edição, tratar de suas intenções para a publicação da obra:

\begin{abstract}
Mando nota prefacial e o livro Religião no Povo, publicado pela Universidade da Paraíba, em 1974, cujo texto é matéria convergente para o nosso planejado 'Superstição no Brasil'.

Submeto à sua apreciação julgadora a reunião dele aos outros dois antecedentes, constituindo um volumão compacto e valioso para leitura e consulta como não existe em nenhuma bibliografia na espécie. Se não aprovar, devolva o volume porque tenho poucos. Leia o índice e verá a unidade temática do livro. Plena liberdade em sua decisão. Um respeitoso abraço do seu devoto.

Não concordando com a reunião do terceiro livro na 'Superstição no Brasil', retire no prefacial o período em que se alude a inserção (Id. Ibidem, p. 12).
\end{abstract}

\footnotetext{
${ }^{27}$ Sobre o tema da superstição, Cascudo ainda publicou Anúbis e outros ensaios (1951) e Voz de Nessus (1966). Este último foi analisado no terceiro capítulo do livro Luís da Câmara Cascudo e a Invenção do Feminino na “cultura-popular-nordestina” (1938-1977) Cf. (OLIVEIRA, 2009, p. 96-108).

${ }^{28}$ Em carta destinada a João Lyra Filho, Cascudo também se refere ao que acima discutimos: "Assinei contrato com a LCT EDITORA, a mesma da Antologia da Alimentação no Brasil, para imprimir a nossa Superstição! Já remeti a tralha dos 35 capitulos, alguns duas folhas e outros ensaios capitosos como os seus" (CC, 23-II-1978, apud, CASCUDO, 2005b, p. 150).

${ }_{29}$ Originalmente publicado com um prefácio de Umberto Nóbrega, reitor da UFPB, na época da sua primeira edição. Não consta o mesmo na coletânea Superstição no Brasil.
} 
Além deste que aqui tratamos, podemos dizer que Cascudo publicou apenas três pesquisas inéditas depois de 1975: História dos nossos gestos (1976), Antologia da alimentação no Brasil (1977), que foi iniciado em 1964, tendo sido finalizado em 1974, e o’ Príncipe Maximiliano no Brasil, $1815-1817$ (1977), ensaios cujos originais permaneceram perdidos de 1935 a 1976 (CASCUDO, 2005b, p. 110). Ao anunciar a João Lyra Filho seu novo projeto de pesquisa, ocasião em que pediu a colaboração do amigo, Cascudo menciona Antologia da Superstição no Brasil. Posteriormente, a pesquisa recebeu novo título Geografia da superstição no Brasil, e na última referência, apenas Superstição. Esta pesquisa jamais foi publicada; possivelmente, os originais tenham se extraviado, como muitos outros livros que Cascudo teve a oportunidade de produzir; como sabemos, alguns foram recuperados e publicados, outros não tiveram a mesma sorte. Entretanto, o respectivo debate, em crítica genética, serve para que pensemos a respeito da vasta capacidade e do ânimo de Cascudo em congregar a participação de muitos intelectuais, como João Lyra Filho e Oswaldo Lamartine de Faria em seus projetos intelectuais durante o período em análise.

Por fim, embora quebre a linha temporal dos documentos aqui analisados, temos uma missiva onde Cascudo irá tratar de sua amizade e interlocução de anos com Mario de Andrade, que é lembrado pelo etnógrafo e historiador potiguar na carta que ele escreve a Oswaldo em vinte e seis de maio de $1973^{30}$. Inspirado pela proximidade do centenário de nascimento de Juvenal Lamartine (1874-1956), Cascudo dá a sua versão para um fato que acompanhou de muito perto, segundo ele, a "História de Mario Andrade, proprietário em Natal". É o seu relato sobre a compra da casa que Juvenal Lamartine fez no intuito de convencer Mário a passar verões em Areia Preta, fazendo-o ainda mais conhecedor da cultura nordestina, em especial a potiguar (CASTRO, 2015, p. 123):

OSWALDINHO querido: - Em dezembro de 1928 Mario de Andrade foi meu hóspede em Natal, uns quinze dias na grande chácara da Av. Jundiaí, que V. conheceu ainda menino. O presidente Juvenal Lamartine tornou-se amigo pessoal do Macunaíma. Voltando a S. Paulo, Mario defendeu em três artigos o trabalhador nordestino que ele vira em plena seca no sertão de pedra e sol. Em principios de 1930

\footnotetext{
${ }^{30}$ Vale salientar, que até a data da publicação de Cascudo para Oswald (2005), este seria o único registro epistolográfico impresso e de livre acesso, cujo qual, pode ser visto, Cascudo falar sobre sua relação com o escritor Mário de Andrade.
} 
Lamartine comprou ao tte. Manuel Cavalcanti um pequeno bangalô em [sic] este fizera construir na praia de Areia Preta, logo no princípio da praça, hoje Governador Silvio Pedroza. Pagou um conto de reis ao Cavalcanti. O bangalô tinha uma grande sala-de-estar, dormida, W. C. e cozinha cabiam numa gaveta. Meu pai possuía uma casa de veraneio, vizinha, longa, agradável, com alpendre, toda de taipa. Custava dois contos em 1923, quando pertencera ao general João Augusto. Desmoronou-se e hoje é viveiro de lagartixas e malvas. Lamartine desejava vincular Macunaíma ao Nordeste fazendo-o conhecedor das realidades locais, vindo passar férias ou verões em Areia Preta. Mario ficou radiante e cheio de planos de trabalho. Veio a remandiola de outubro de 1930. Lamartine era acusado de ter dado sumiço ao cavalo branco de S. Jorge e ao cachorro de S. Roque. Os autenticos iniciaram cem investigações com todos os intuitos desmoralizantes. Desagradável para Mário ser incluído entre os cumplices e aproveitadores dos Carcomidos, explorado seu nome no fácil noticiário de escândalo na imprensa carioca e paulista. Fiz anular o registro do pequenino imóvel no cartório tranquilizando Mário. Cavalcanti vendeu o bangalô ao Nival Camara e este construiu a grande vivenda. Creio que ainda existe, logo no começo de Areia Preta onde não vou há dois anos... Essa é a História de Mario de Andrade "proprietário em Natal". Dos personagens participantes resto eu. Mario, Lamartine, a casa, morreram...

Informe ao Inojosa, velho amigo meu, companheiro na campanha da ARTE MODERNA de que ele é evocador no Recife (CC, 26-V-1973, apud, LAMARTINE DE FARIA, 2005, p. 27-28).

A carta demonstra aspectos interessantes sobre os laços de amizade que Mário de Andrade estabelecerá em Natal com Juvenal Lamartine durante a época de sua estadia de 15 dias na residência de Cascudo no final de 1928. Mário, quando voltou a São Paulo, escreveu três artigos, onde defendeu "o trabalhador nordestino que ele vira em plena seca no sertão de pedra e sol”. Lamartine ficou tão entusiasmado que “desejava vincular Macunaima ao Nordeste, fazendo-o conhecedor das realidades locais, vindo passar férias ou verões em Areia Preta" ${ }^{31}$. Em carta de 9 de maio de 1930

\footnotetext{
${ }^{31}$ Consultando a correspondência, é possível perceber, que depois da viagem feita por Mário ao Rio Grande do Norte, o mesmo ficou com vontade de possuir residência em Natal: [...] "Viver aí não poderei porém não desisti de ter aí minha maloca numa praia natalense. Se não mando a procuração dentro desta é porque não sei o nome todo do coronel Cascudo, - pra ele requerer o terreno e o resto. Você, cumpanhero, vai me responder por avião mesmo, dando norma da procuração, nome de seu pai e quanto tenho que enviar pros movimentos regulamentares de fixação pra mim do terreno, etc. Espero resposta logo, hein!"
} 
e por intermédio de fotografias anexas, Câmara Cascudo dá notícia a Mário, que parece ter ficado curioso com "a casinha, simplizinha que parece de sapê", procurando saber a quem pertencia:

Pois é sua, bestão querido e oxalá. Estou 'oficialmente' autorizado a mandar-lhe as fotos da casinha. Dr. Lamartine já tem a escritura que eu receberei na próxima semana e mandarei registrar em cartório. Para sossegar-lhe o ânimo susceptível devo dizer-lhe que o governo não figura em ato algum. Tudo se passa diretamente entre Mário de Andrade, professor, brasileiro, morador em S. Paulo por seu bastante procurador bacharel fulano de tal [Cascudo] e o ex-proprietário Francisco Azevedo. A casa foi feita em outubro de 1929. É pequena, limpa, a dois passos de mim. Umas duas pessoas é que sabem. Não disse a viva alma a não ser os de casa que me ajudaram. Especialmente papai. Os $500 \$$ entraram agora em fogo. Vão servir para um muro de arrimo contra o morro que eu chamo muito inocentemente 'Morro de Ci'.

(...) Em fevereiro fui passar um mês em Areia Preta e topei com a casa. Achei graça. Estava dentro de suas instruções. Falei ao Dr. Lamartine que imediatamente aceitou-me e autorizou-me as marchas. Sempre em seu nome e não do governo. Agora tudo ficou concluído. Fui pedir-lhe instruções para passá-las a V. Disse-me: Escreva a Mário dizendo que apareceu essa casinha no terreno e como o acrescido pertence ao dono da coisa que se acresce, a casa é dele e espero que ele venha matar saudades nossas e pode ser que da parte dele também! (CC, 9-V-1930, Apud, CASCUDO, 2010a, p. 174).

Sobre esse presente dado pelo Rio Grande do Norte, Mário de Andrade escreverá de São Paulo, em 30 de junho de 1930, uma agradecida carta a Juvenal Lamartine: "Acabo de saber pelo Cascudinho que afinal o meu terreno de Areia Preta virou casa (...) Fico-lhe imensamente grato pela generosidade (...) continuarei procurando fazer jus a sua simpatia, trabalhando do meu jeito pelo Rio Grande do Norte" (MA, 8-VI-1930, apud, LAMARTINE DE FARIA, 2005, p. 29-30). Publicada na íntegra entre a correspondência de Cascudo para Oswaldo, a carta de Mário

(MA, 6-III-1929, Apud, CASCUDO, 2010a, p. 155). Aproveitamos a oportunidade para informar que deste momento em diante, toda e qualquer referência realizada no corpo deste texto, referenciando a correspondência de Mário e Cascudo, terá por base a edição organizada e editada por Marcos Antonio de Moraes Cf. (CASCUDO, 2010a). 
demonstra sua admiração pelo político Juvenal Lamartine e como ele se sentia familiarizado com o Estado, o qual ele chama de "também 'meu' Rio Grande do Norte" (CASTRO, 2015, p. 124) ${ }^{32}$.

Como podemos observar ainda na carta de Cascudo enviada a Oswald Lamartine em 26 de maio de 1973, os sonhos feitos por Mário em torno da posse da propriedade serão desfeitos até outubro de 1930. A Revolução de outubro de 1930 e as transformações que trouxe em seu bojo alteraram estes projetos de Mário como os de Cascudo. De imediato, Cascudo que, bacharelado pela Faculdade de Direito do Recife, desdobrava sua inserção em esfera local pelas vias da política, havia sido eleito deputado estadual, perdeu seu mandato com três dias de cargo, perdendo igualmente as posições conquistadas pelas suas relações com o governo de Juvenal Lamartine. Mário teve sua casa invadida e vigiada na procura por seu irmão, por conta das perseguições aos perrepistas. Estes e outros abalos de maior alcance anunciavam outros caminhos de atuação para eles (BYNGTON, 2000, p. 89).

Depois de contada a história da casa de Mário para Oswald como o último sobrevivente do episódio, Cascudo pede para que "Informe ao Inojosa, velho amigo meu, companheiro na campanha da ARTE MODERNA de que ele é evocador no Recife". No livro Os Andrades e outros aspectos do Modernismo (1975), em texto que fala sobre a segunda viagem de Mário de Andrade ao Nordeste, Inojosa afirmou que esta carta enviada por Cascudo em vinte e seis de maio de 1973 ao amigo comum que tinham - Oswald Lamartine - foi de certo modo a ele direcionada para que tivesse a possibilidade de se informar dos acontecimentos após sua partida para o Rio de Janeiro 33 :

\footnotetext{
${ }^{32}$ Em carta enviada a Manuel Bandeira no dia dezenove de maio de 1930, Mário conta entusiasmado sobre a posse do terreno e da casa na praia de Areia Preta em Natal, colocando-a a disposição do amigo: (...) "encerro esta lhe comunicando que estou de posse já duma casinha de dois centímetros na praia de Areia Preta em Natal. Um centímetro é meu e o outro de você, quando quiser vá sozinho. Basta chegar, falando: esta casa é de meu amigo Mário de Andrade e vim morar nela. O pessoal que está lá de graça, vai saindo e você se instala. O caso da casa, contarei quando for aí. Mas chegou justamente no momento em que eu acabava de escrever um prefácio maluco pro Belarte, em que dizia 'e se Deus me der dinheiro é no Nordeste que hei-de-morrer'. Casa já tenho e a resolução de passar no Nordeste meu fim de vida é séria. Não aturo esta amaldiçoada São Paulo, que na semana passada inda me botou de cama três dias, com um resfriado filho da mãe" (MA, 19-V-1930, apud, MORAES, 2001, p. 446). Como se sabe, Mário nunca retornou ao Nordeste, embora sua estadia nos anos de 1927 e 1928 tenha mudado significativamente sua vida no âmbito pessoal e intelectual.

${ }^{33}$ Faz-se necessário lembrar que Joaquim Inojosa era ligado com o grupo político dos Pessoa de Queiroz, que à época apoiava a política do então presidente do Brasil o sr. Washington Luiz, com o estopim da revolução de trinta, teve que fugir as pressas para o Rio de Janeiro para não sofrer represálias (Cf. INOJOSA, 1980, p. 16). O curioso é que na correspondência estabelecida entre Cascudo e Inojosa não existe nas cartas de 1973, nenhuma alusão ao fato. Existe apenas no corpo desta epistolografia a menção
} 
Estava-se em 3 de junho de 1930. No mesmo ano, com a revolução de 3 de outubro, Juvenal Lamartine teria que abandonar o governo. Receando as prováveis explorações contra o ato de doação de casa e terreno a um escritor estranho à terra, apressou-se Câmara Cascudo em desfazer o ato governamental. Explica nesta carta a Oswald Lamartine, atendendo a um pedido de informação que eu lhe fizera por intermédio deste amigo comum (...) (INOJOSA, 1975, p. 207).

Estes últimos aspectos colocam os elementos que serão discutidos ao longo deste trabalho, numa perspectiva diferenciada do já estabelecido sobre a relação de Cascudo com Mário de Andrade e com o Modernismo no Rio Grande do Norte e no Nordeste. Veremos que Inojosa, terá significativa participação tanto na divulgação imediata, como na tentativa de elaboração de um lugar de memória para si na divulgação do Modernismo pelo Brasil a posteriori. Para a realização deste propósito, faz-se necessário, a partir de agora, compreender como a produção discursiva em torno da correspondência de Mário e Cascudo, atrelou sua experiência modernista como eixo explicativo para toda sua obra.

ao lançamento e recepção do livro Os Andrades e outros aspectos do Modernismo (Cf. ARAÚJO, 2012, p. 145-146). 


\title{
3. Capítulo II:
}

\section{DAS CARTAS COMO DOCUMENTAÇÃO E MONUMENTALIZAÇÃO:}

Os estudos sobre a correspondência entre Câmara Cascudo e Mário de Andrade em perspectiva historiográfica ${ }^{34}$

\begin{abstract}
O documento não é inócuo. É, antes de mais nada, o resultado de uma montagem, consciente ou inconsciente, da história, da época, da sociedade que o produziram, mas também das épocas sucessivas durante as quais continuou a viver, talvez esquecido, durante as quais continuou a ser manipulado, ainda que pelo silêncio. (...) um monumento é em primeiro lugar uma roupagem, uma aparência enganadora, uma montagem. É preciso começar por desmontar, demolir esta montagem, desestruturar esta construção e analisar as condições de produção dos documentos-monumentos (LE GOFF, 2003, p. 537-538).
\end{abstract}

\subsection{Sobre a crítica dos documentos/monumentos: o Cascudo modernista}

O que transforma o documento em monumento? Tomando por base as proposições de Jacques Le Goff, é necessário reconhecer em todo documento um monumento. Pois não existe um documento objetivo, inócuo, primário, tal como ansiava a ilusão positivista, a qual via no documento uma prova de boa fé, desde que fosse autêntico (produzido por uma sociedade cujos dominantes tinham interesse que assim fosse). Podemos afirmar que a concepção do documento/monumento é, pois, independente da revolução documental, e entre seus objetivos está o de evitar que esta revolução necessária se transforme num derivativo e desvie o historiador do seu dever principal: a crítica do documento - qualquer que ele seja - enquanto monumento. $\mathrm{O}$ documento não é qualquer coisa que fica por conta do passado, é um produto da

\footnotetext{
${ }^{34}$ De acordo com Julio Aróstegui (2006), a ligação do método historiográfico ao assunto das fontes é tão estreita que durante muito tempo, a maioria dos tratamentos clássicos do método historiográfico limitouse a tratar de forma quase exclusiva o problema das "fontes da História". Uma fonte de informação nunca é neutra, nem dada de antemão. Pesquisar a história não consiste em transcrever o que as fontes "dizem". Mas pensar o método historiográfico como uma ferramenta que precisa tornar inteligível e explicável o que as fontes oferecem como informação, pois o historiador deve, como qualquer outro pesquisador social, "construir" também suas fontes, ainda que se encontre mais limitado na medida em que retrocede no tempo. Desse modo, a cronologia, de forma alguma, esgota o problema do tempo histórico e não acaba nela a necessidade do historiador e do método historiográfico de considerar todos os fenômenos no interior da variável tempo (ARÓSTEGUI, 2006, p. 94-95).
} 
sociedade que o fabricou segundo as relações de força que aí detinham poder. Só a análise do documento enquanto monumento permite recuperá-lo e ao historiador usá-lo cientificamente, isto é, com pleno conhecimento de causa (LE GOFF, 2003, p. 535536).

Michel Foucault, já havia colocado claramente esta questão em a Arqueologia do Saber (2007), quando afirmou que "o documento não é o feliz instrumento de uma história que seria em si mesma, e de pleno direito, memória; a história é, para uma sociedade uma certa maneira de status e elaboração à massa documental de que ela não se separa". Dito de outro modo, temos que, a história, em sua forma tradicional, se dispunha a "memorizar" os monumentos do passado, transformando-os em documentos e fazendo falarem estes rastros que, por si mesmos, raramente são verbais, ou que dizem em silêncio coisas diversas do que dizem; em nossos dias, a história é o que transforma os documentos em monumentos e que desdobra, onde se decifravam rastros deixados pelos homens, onde se tentava reconhecer em profundidade o que tinham sido: uma massa de elementos que devem ser isolados, agrupados, tornados pertinentes, interrelacionados, organizados em conjunto (FOUCAULT, 2007, p. 8).

Um documento não faz sentido apenas porque é submetido ao escrutínio da razão, ele faz sentido porque é sentido, porque afeta, toca, atinge, chama a atenção, desperta a sensibilidade daquele que lê. Um dado documento torna-se elegível, copiável, reprodutível, citável, não apenas porque dadas intenções, dados problemas, dados temas, dados conceitos, dadas teorias e metodologias, dadas teses nos movem, mas também, e talvez, principalmente, porque o tal documento nos comove. Faz-nos moverse em dada direção e nos embalam com dadas sensações e emoções. O documento não mostra, não demonstra, não desvela, tão pouco resgata, a não ser que seja através da voz de quem os consulta, analisa, atribui sentido e significado. $\mathrm{O}$ documento aparece no texto quando o autor assim o permite, no contexto da argumentação que ele prepara, na trama narrativa que ele enreda. $\mathrm{O}$ documento não faz sentido em si mesmo, só faz sentido nessa relação com o outro. É preciso a intencionalidade do pesquisador para que algum artefato possa ser considerado documento, é preciso uma série de operações para que ele venha assim se constituir, a pesquisa histórica avança num movimento de entrada e saída do corpo do documento (ALBUQUERQUE JR, 2013b, p. 20; 26).

A amizade entre Câmara Cascudo e Mário de Andrade tem sido referência obrigatória em qualquer narrativa da vida e obra de Cascudo. Analisar a década de 20 no Rio Grande do Norte, em seus aspectos culturais, é quase exclusivamente tratar da 
aproximação de Câmara Cascudo com o movimento modernista, através da influência marioandradiana. As teias dessa trama discursiva são tão fortes que é praticamente impossível alguns autores dela escapar.

Reproduz-se para Cascudo uma memória cristalizada de sua experiência modernista que, ao exaltá-lo, o insere no rol dos "grandes escritores modernistas" e que, em contrapartida, apaga outras experiências ocorridas naquele momento; sobretudo para um sujeito que experimentava a tensão do advento da modernidade em uma cidade provinciana como Natal, explica-lo unicamente através do Modernismo não seria uma atitude reducionista, não apagaria todas as contradições, todos os seus pontos conflitantes? (SALES NETO, s/d., p. 2).

Para repensarmos a atuação intelectual de Luís da Câmara Cascudo, durante as décadas de 20 a 40, momento em que esse escritor ocupa o "lugar de sujeito" autor (FOUCAULT, 1992, p. 29-86), como crítico literário e historiador, faz-se necessário demonstrar como foi constituído este aspecto de sua biografia, onde ficam acentuadas suas relações com o Movimento Modernista. No capítulo anterior, quando dividimos cronologicamente toda a produção recente sobre a epistolografia cascudeana, falávamos que o grande nome da segunda fase desta produção discursiva, seria Veríssimo de Melo. Veremos a partir de agora, como suas teses contribuíram para legitimar este topos ${ }^{35}$ instituído nos estudos sobre a obra de Luís da Câmara Cascudo.

\subsection{Primeiro momento: Veríssimo de Melo (1971-1998)}

Segundo Francisco Firmino Sales Neto (2008), na qualidade de amigo de alguns escritores envolvidos no Movimento Modernista, notadamente de Ascenso Ferreira e de Joaquim Inojosa, Veríssimo de Melo levou o "Cascudo modernista” à condição de tese. Buscou Veríssimo provar que a obra folclórica de Câmara Cascudo obedeceu a um programa de estudos iniciado em 1922, com a Semana de Arte Moderna. De acordo com Sales Neto, foi nesse sentido que, sob forte impacto e repercussão da morte de Câmara Cascudo, em julho de 1986, Veríssimo de Melo publicara no jornal A República

\footnotetext{
${ }^{35}$ Ideia ou tema que orienta a maneira como os historiadores compreendem seu objeto de pesquisa, ou até mesmo sua produção. Não raro, a própria historiografia desabonou o topos como fórmula cega, se tornando ainda mais difícil esclarecer a diferença que sempre existiu entre o mero emprego do lugar comum e seu efeito prático. A despeito desses problemas, a longevidade do respectivo topos - a tese sobre o Cascudo modernista - já é bastante esclarecedora, pois impõe flexibilidade da formulação nos campos de conhecimento das ciências sociais, letras e na história como na permanência de seu significado (KOSELLECK, 2006, p. 42).
} 
o artigo intitulado A obra folclórica de Cascudo. Este artigo tinha por único objetivo mostrar que todos os livros de Cascudo sobre folclore só foram possíveis graças ao respectivo plano de 1922. Neste artigo, não foi apenas a obra literária de Cascudo que recebeu algum tipo de influência do Modernismo, mas principalmente, a obra histórica e, ainda mais, as obras folclóricas observem no fragmento a seguir (SALES NETO, 2008, p. 63):

\begin{abstract}
Estou seguramente convicto de que tudo partiu de plano antigo, elaborado antes da publicação do seu primeiro livro [de Cascudo] no campo folclórico, 'Vaqueiros e Cantadores' cujo prefácio está datado de dezembro de 1937, saindo a segunda edição em 1984, pela Itatiaia, de Belo Horizonte. Esse livro começou a ser escrito - como ele próprio assinala - em 1922, ano do Movimento Modernista no Brasil. Sabe-se que Cascudo foi um dos animadores do Movimento no Rio Grande do Norte, ao lado do único poeta que se destacou como pioneiro das novas ideias no nosso Estado - Jorge Fernandes.

Cascudo foi amigo íntimo e cordial de Mário de Andrade - líder nacional do movimento paulista - tendo mantido com ele assídua e copiosa correspondência (MELO, 1986).
\end{abstract}

Não foi só em 1986, que Veríssimo veio a propor a tese do Cascudo modernista. Já em 1971, na plaquete Contribuição do Nordeste ao Movimento Modernista, publicada em Natal pela Fundação José Augusto, o crítico literário já tratava dessa participação e divulgação do Modernismo no Rio Grande do Norte por intermédio de Cascudo e Jorge Fernandes ${ }^{36}$ :

\footnotetext{
36 Cf. (...) “Quem é esse Jorge Fernandes, hein? A apresentação de você [Cascudo] está engraçadíssima. E o tal de Jorge Fernandes me deixou com água no bico. É bom mesmo. Sensibilidade e inteligência me pareceu. (...) Que achado formidável. Dê um abraço no Jorge Fernandes”. (...) (MA, 6-IX-1925, apud, CASCUDO, 2010a, p. 63). Numa carta escrita em três de fevereiro de 1926, Mário chega a duvidar da existência de Jorge Fernandes, e até a pensar que o mesmo fosse o "eu" lírico de Cascudo: (...) "Me mande dizer alguma coisa certa sobre aquele poeta 'dos poetas que morreram talvez na guerra contra Paraguai’. É invenção de você o existe realmente? (...) Se existe me mande mais alguma coisa dele. Se não existe e é invenção de você fique sabendo que é uma invenção grande, você deve firmar a psicologia dele e fazer dentro dessa psicologia ao menos uma plaquete. Garanto que saía interessantíssimo". (MA, 3II-1926, Id. Ibidem, p. 89). Cascudo confirmará posteriormente a existência de Jorge Fernandes, comenta brevemente sobre o perfil do poeta potiguar, encaminha outros versos e o endereço do mesmo, para que Mário tirasse a "prova dos nove": (...) "Jorge Fernandes existe. É homem retraído, altivo, amigo de três ou quatro e com uma presciência das coisas da Arte. Remeto alguns poemas dele publicados n' $A$ Imprensa. Endereço do Jorge - Rua Vigário Bartolomeu 605 - Natal” (CC, 9-III-1926, Id. Ibidem, p. 95). Sobre as cartas de Jorge Fernandes, Mário menciona a Cascudo que: (...) "O Jorge Fernandes é lacônico mas é batuta. Cartas deste tamanhinho porém manda versos e essa é uma felicidade pra mim. Acho ele um bruto poeta". (MA, 22-VII-1926, Id. Ibidem, p. 115).
} 
Foi Cascudo quem primeiro contactou com Mário de Andrade e outros líderes do Modernismo, apresentando Jorge Fernandes e outros nomes do Rio Grande do Norte. Mário de Andrade ficou encantado com os primeiros poemas que recebeu de Jorge Fernandes e, vindo a Natal, por ocasião de uma visita a Cascudo, foi abraça-lo ${ }^{37}$. Numa das raras cartas de Mário a Jorge Fernandes, que nós recolhemos e publicamos, êle nos oferece êste depoimento sôbre os poemas de Jorge: 'Têm nêles um certo ar brusco meio selvagem, meio ríspido e no entanto côa de tudo uma doçura e um carinho gostoso... Você é original, é incontestável e é duma originalidade natural, nada procurada. Fique certo que ando guardando os poemas de você como dos mais interessantes dentre os de nosso Brasil de hoje (MELO, 1971, p. 16)

Vendo as citações anteriores, podemos perceber que Veríssimo, tinha uma relação de intimidade tanto com Cascudo, como com o poeta Jorge Fernandes; além do mais, o que para nosso estudo se torna especialmente relevante: ele tinha conhecimento da correspondência de Mário de Andrade e Câmara Cascudo (talvez tenha sido o primeiro a saber de sua existência), realizada ao longo das décadas de 20 e 40 do século passado. Durante a pesquisa que realizamos no Ludovicus - Instituto Câmara Cascudo em Natal, RN, tivemos a oportunidade de catalogar em torno de 18 correspondências de Veríssimo de Melo, destinadas a Cascudo, destas, a mais relevante é uma carta de vinte e um de abril de 1979, o crítico literário trata de questões referentes à II Semana da cultura nordestina que a UFRN estava promovendo ${ }^{38}$ e comenta que o escolheram para falar sobre algum aspecto da obra ou personalidade de Câmara Cascudo. Melo escolheu um: Luís da Câmara Cascudo - o epistológrafo. Já havia escrito umas dez páginas, praticamente, mas precisava de algumas informações essenciais. Eis as perguntas:

- Da sua correspondência além de Mário de Andrade, Nilo Pereira e Thaville, quais os outros escritores ou amigos que devem ser citados como os que mais se corresponderam com você?

- As cartas de Mário de Andrade para você estão arquivadas? (Só a informação). Você não guardava cópias da sua?

\footnotetext{
${ }^{37}$ Cf. (...) "E se eu sinto não ter podido ficar por mais tempo na companhia de você [Cascudo] e do Jorge Fernandes isso nem se pergunta. Aquele momentinho vivido no naquele sótão de vocês, foi vivido mesmo, que ritmo harmonioso de nós três apesar de tão distantes um do outro como psicologia, você pegando fogo, eu gozado, o Jorge Fernandes calmo... Ah, vida vida, vida comovida ...” (...) (MA, 29-IX1927, Id. Ibidem, p. 135).

${ }^{38}$ A I Semana de Cultura Nordestina ocorreu em 1978, contou com a participação de Câmara Cascudo, Gilberto Freyre e outros. Será objeto de discussão do último capítulo desta tese.
} 
- De modo geral, está conservada a enorme correspondência que tem recebido de escritores do Brasil e exterior?

- Pode-se dizer que você tem um arquivo de cartas organizado?

- Qual a carta ou as cartas mais famosas, que se lembre, você ainda tem em arquivo?

- Gostaria que relembrasse alguns endereços interessantes nas suas cartas, de amigos distantes. Como aquele do angolano que tem sua caricatura $^{39}$.

- De modo geral, pode-se considerar importante a sua correspondência como contribuição à sua obra? Obtendo livros raros e informações as mais diversas?

São estas e outras perguntas no gênero que eu gostaria que você me respondesse, sem falta, para completar o meu trabalho. Faço uma análise das suas cartas para Thaville, retirando o que achei mais curioso. Penso que o trabalho está saindo bom. Você há de vê-lo breve. José Américo de Almeida me deu um depoimento especial sobre sua correspondência, assim como Nilo Pereira.

À tarde de 22 eu passarei aí para pegar as informações.

Meu abraço e sempre a velha amizade e admiração (VM, 21-IV1979)

Através de análise da obra de Veríssimo, podemos descobrir que esse tema está desenvolvido e divulgado originalmente na plaquete Cascudo em Dois tempos - edição de A República, Natal, 1979 -, onde foram reunidas observações sobre dois aspectos da atividade intelectual de Cascudo: O Professor e o Epistológrafo. Posteriormente, esse estudo foi editado e apresentado apenas em sua segunda parte, com acréscimos e novo título: Cascudo: o escritor de cartas ${ }^{40}$ pela editora Thesaurus (MELO, 1993a, p. 12).

Nessa nova apresentação, é possível contemplarmos a secção Correspondência passiva de Cascudo está preservada; nela, vemos que o encontro ocorreu numa entrevista, quando Cascudo afirmou que "toda correspondência é importante. Nenhum livro de Machado de Assis, de Flaubert, de Monteiro Lobato constitui maior depoimento do que as suas cartas particulares". Informando sobre os nomes de escritores, no país, com os quais manteve mais assídua e intensa correspondência, citou

\footnotetext{
${ }^{39} \mathrm{O}$ mais original envelope que Cascudo recebeu em toda a sua vida foi o do pintor e desenhista português Neves e Souza, que residia em Angola. Ele colocou, no alto do envelope, o Exmo. Sr. E logo abaixo, em lugar do nome de Cascudo, uma caricatura do escritor potiguar, fumando o seu clássico charuto, inconfundível pelo realismo dos traços (MELO, 1993a, p. 6).

${ }^{40}$ Este título foi utilizado por Veríssimo de Melo em um artigo que publicou no jornal a' República em doze de outubro de 1986. Neste artigo, é possível contemplar uma síntese da plaquete supracitada.
} 
alguns nomes: Mário de Andrade, Manuel Bandeira, Carlos Drummond de Andrade, Nilo Pereira, Cassiano Ricardo e Monteiro Lobato. Deste último, acrescentou que devia ter mais de duzentas cartas ${ }^{41}$. No exterior, o maior volume na troca de correspondência se efetuou com Arthur Coelho, em Nova York, e Perry Vidal, em Lisboa, diretor da Biblioteca da Ajuda. Cascudo havia confessado a Veríssimo que a maioria das cartas de Mário de Andrade estava guardada em arquivo. E de modo geral - sua correspondência passiva essencial estava conservada ${ }^{42}$. Mas adiantou que seu arquivo estava desorganizado, fazendo blague, Cascudo teria dito: "Senão eu não deixaria nada a fazer aos pesquisadores, depois da minha morte...". Veríssimo ainda teria indagado se ele permitiria a publicação das cartas que enviou a Mário de Andrade que ainda hoje são preservadas pelo IEB/USP, respondendo que de modo nenhum o faria (Id. Ibidem, p. 5$6)$.

Em 1989, Veríssimo retoma as proposições do seu artigo de 1986, de forma ampliada, com o título de A obra folclórica de Câmara Cascudo como expressão do Movimento Modernista, lido na posse do antropólogo, na Academia Norte-RioGrandense de Ciências, em elogio a Luís da Câmara Cascudo, patrono da cadeira que estava a assumir. De inédito, esse texto possuía apenas o esforço de ordenar as ideias sobre o Modernismo em um arranjo mais argumentativo, pois como vimos, a tese vinha sendo construída desde 1971 (SALES NETO, 2008, p. 64):

Estamos convictos de que Cascudo elaborou plano gigantesco de trabalho - no que se refere à obra folclórica - por influência do Movimento Modernista.

Baseamos nossa dedução nos seguintes pontos:

$1^{\circ}$ ) - Em repetidas declarações dele que iria escrever um livro sobre cada aspecto mais significativo do folclore brasileiro;

$2^{\circ}$ ) - Na afirmação que faz no seu primeiro livro sobre folclore VAQUEIROS E CANTADORES, editado em 1939, pela Globo, de Porto Alegre, embora a introdução esteja datado do ano de 1937 - de que aquela obra começara a ser escrita em 1922 - ano, como se sabe, da Semana de Arte Moderna, em São Paulo, que deflagrou o Movimento Modernista;

\footnotetext{
${ }^{41}$ Em pesquisa realizada no Ludovicus - Instituto Câmara Cascudo, encontramos apenas 18 cartas enviadas por Lobato a Cascudo. São onze manuscritas e sete datiloscritas. Cf. (LAJOLO, 2013, p. 14-31; TIN, 2007a, p. 519-529).

${ }^{42}$ Recentemente, o Ludovicus - Instituto Câmara Cascudo disponibilizou toda a correspondência passiva de Câmara Cascudo, estima-se um número aproximado de quinze mil documentos inéditos.
} 
$\left.3^{\circ}\right)$ - Na correspondência copiosa que manteve com Mário de Andrade - o principal corifeu daquele Movimento - correspondência que ainda se mantém inédita;

$4^{\circ}$ ) - No próprio entusiasmo que demonstrou pelo Movimento Modernista em Natal, influenciando poetas como Jorge Fernandes e Jaime dos Guimarães Wanderley - pioneiros do Modernismo no Rio Grande do Norte (MELO, 1989a, p. 11-13).

A passagem do discurso que citamos demonstra como os pontos argumentativos se repetiram através dos anos, estabelecendo uma regularidade discursiva capaz de impor essa interpretação como a mais coerente para a análise da atuação intelectual de Câmara Cascudo a partir de um marco temporal e de significação exterior ao Rio Grande do Norte: a Semana de Arte Moderna de 1922, em São Paulo. Em maior ou menor grau, os argumentos apresentados por Veríssimo representaram a consolidação dessa chave interpretativa. Veríssimo de Melo, em seu pronunciamento na Academia Norte-Rio-Grandense de Ciências, enfatizou que só a leitura das cartas trocadas entre Mário de Andrade e Luís da Câmara Cascudo poderia determinar a confirmação plena de sua dedução:

\footnotetext{
Todavia, a confirmação plena de nossa dedução poderá melhor configurar-se com a leitura da correspondência que ele manteve com Mário de Andrade - correspondência que está preservada, conforme nos confessou [Câmara Cascudo] (MELO, 1989a, p. 15).
}

Os originais das cartas enviadas por Mário de Andrade a Cascudo foram entregues a Veríssimo de Melo, pessoalmente, por d. Dhália Freire Cascudo, no dia 10 de julho de 1989, atendendo a solicitação de Diógenes da Cunha Lima, presidente da Academia Norte-Rio-Grandense de Letras; Melo publicou as cartas de Mário em edição institucional da associação no ano de 1991. Na ocasião, ele argumentou que essa correspondência comprovava amplamente o que tinha previsto em outras oportunidades (MELO, 1993a, p.45-46), mesmo antes de conhecê-la: a influência decisiva que Mário de Andrade exercera na orientação dos estudos folclóricos de Luís da Câmara Cascudo; enfatizando, que Cascudo fora um modernista da primeira hora ao lado do mais importante corifeu do movimento de renovação das nossas letras (MELO, 2000, p. 1520). 
As cartas eram, ao todo, cinquenta e seis, sendo vinte e duas manuscritas e trinta e quatro datilografadas. Há ainda, ainda no acervo, dois bilhetes de Mário, além de recortes de dois artigos dele; um intitulado "O Desafio Brasileiro", publicado no "Estado de São Paulo", 23/11/41; e outro "Separatismo Paulista", datilografado, sem data; e o artigo, datilografado de Luís da Câmara Cascudo, "Desafio Africano", datado de 28/12/41, com a letra do próprio punho de Cascudo, anexados na respectiva edição (MELO, 2000, p. 16).

Além dos argumentos que já apresentamos; Veríssimo de Melo buscou reforçar sua tese através de uma missiva enviada por Mário em nove de junho de 1937, a qual chamou de "carta terrível". Nela, o escritor paulista criticava a postura teórica e os temas a que Câmara Cascudo vinha se detendo até aquele momento ${ }^{43}$. Não há dúvida de que o tom da carta é forte e que deve ter causado um profundo impacto em Cascudo. Todavia, para Veríssimo, o maior impacto se deu na obra de Cascudo, que teria mudado radicalmente. Assim sendo, Veríssimo de Melo deslocou o marco temporal e de significação da obra de Câmara Cascudo da Semana de Arte Moderna, em 1922, para o ano de 1937, com a "carta terrível”. Na nova avaliação de Veríssimo, esse documento influenciara e dera sentido à obra folclórica de Câmara Cascudo. Nas palavras do próprio anotador das cartas, “A cacetada de Mário de Andrade serviu como aquele hipotético estalo de Padre Vieira: despertou-o para o campo infinito da obra folclórica, agigantando-se e aprofundando-se no estudo e pesquisa da cultura popular" (MELO, 2000, p. 18). Nota-se que houve uma leve mudança nos argumentos, mas a manutenção de sua tese. Pois, para Veríssimo, a correspondência havia comprovado o que ele já previa, mesmo sem conhecer o teor dos documentos (SALES NETO, 2008, p. 67-68).

Humberto Hermenegildo de Araújo (1997) considerou que a introdução e as notas da compilação realizada por Veríssimo apresentavam dificuldades ao pesquisador, devido à omissão de certos trechos das cartas por parte do seu organizador, embora

\footnotetext{
${ }^{43}$ Cf. (...) "É engraçado, você teve uma paciência enorme em colher dados sobre o Stradelli, se carteou com toda a gente, esperou, esperou; você tem uma paciência difícil em colher todas aquelas citações e referências bibliográficas sobre a couvade, logo, você tem paciência. Mas seu desprezo da medida faz com que até agora não tivesse paciência para escrever, senão um livro, pelo menos uma monografia de tema especializado, sobre folclore ao menos do Rio Grande do Norte, pra não dizer Nordeste. (...) Você tem a riqueza folclórica ai passando na rua a qualquer hora. Você tem todos os seus conhecidos e amigos do seu Estado e Nordeste para pedir informações. Você precisa um bocado mais descer dessa rede em que você passa o tempo inteiro lendo até dormir. Não faça escritos ao vai e vem da rede, faça escritos caídos das bocas e dos hábitos que você foi buscar na casa, no mocambo, antro, na festança, na plantação, no cais, no boteco do povo. Abandone esse ânimo aristocrático que você tem e enfim, jogue todas as cartas na mesa, as cartas de seu valor pessoal que conheço e afianço, em estudos necessário e profundos" (...). (MA, 9-VI-1937, apud, CASCUDO, 2010a, p. 295 296).
} 
tenha tido o cuidado de esclarecer os motivos dos cortes para o público leitor. Eles foram feitos, quando dos momentos em que Mário pede sigilo a Cascudo sobre alguns dos temas discutidos na respectiva correspondência. Embora Araújo tenha respeitado o critério de corte adotado por Veríssimo, que certamente se viu diante de uma situação problemática ao organizar a edição das cartas, o autor, não pôde deixar de comentar o fato: é necessário correr o risco de afirmar que os pedidos de reserva de Mário estavam estritamente relacionados a sua consciência de crítico militante da literatura brasileira em formação. Decorridos quase setenta anos daqueles fatos, e num momento em que se tenta ampliar ao máximo possível a história do movimento modernista, tornava-se bastante relativo o desejo de reserva de opiniões de Mário de Andrade (ARAÚJO, 1997, p. 199).

Após a publicação das cartas de Mário de Andrade para Cascudo, Veríssimo volta a tratar de suas teses em mais dois momentos. O primeiro deles, num artigo intitulado: Leitura Crítica das Cartas de Mário de Andrade a Câmara Cascudo (1993b), onde enfatiza os argumentos que já conhecemos e se propõe, neste ano de 1993, em que se comemorava o centenário de nascimento de Mário de Andrade, fazer a releitura de todo esse acervo em seu arquivo. Dos artigos, notas de jornais e missivas de escritores amigos, pinçou o que lhe pareceu mais relevante do ponto de vista crítico, pondo de lado, tanto quanto possível, referências generosas ao organizador:

É evidente que num breve ensaio como este não poderíamos condensar tudo que já se escreveu sobre as Cartas de Mário a Cascudo e nos chegou às mãos. Destacamos mais de quarenta nomes de escritores e jornalistas que se ocuparam do volume das cartas em artigos e notas na imprensa. Alguns através de correspondência. De tudo resultando acervo respeitável de opiniões, impressões, críticas (MELO, 1993b, p. 46)

Neste artigo, Veríssimo faz apenas breve síntese dos artigos e cartas enviadas, percebemos que todos eles são utilizados para referendar sua iniciativa e tese defendida ao longo dos últimos desses 22 anos de produção intelectual que aqui analisamos: 
(...) o volume que organizamos foi lido, comentado e às vezes criticado por mais de quarenta escritores nacionais e estrangeiros ${ }^{44}$. Publicaram-se até agora, mais de trinta artigos sobre o volume das Cartas de Mário a Cascudo, além de inúmeras notas de jornais. Também recebemos sobre o livro dezenas de cartas de escritores amigos. No trabalho que escrevemos para a revista Ciência \& trópicos, da Fundação Joaquim Nabuco, do Recife, consta inventário sintético dos que escreveram sobre a correspondência de Mário e Cascudo, a que intitulamos 'Leitura crítica da correspondência de Mário de Andrade e Câmara Cascudo'. O artigo será publicado na edição que Ciência \& trópicos dedicará a memória do humanista paulista, dentro das comemorações do seu primeiro centenário (MELO, 1997, p. 163).

O segundo e último artigo, também de 1993, mas publicado postumamente em 1997, intitula-se Epistolografia no mês de Mário. Neste texto, Veríssimo fez considerações em torno da vasta publicação existente sobre as cartas enviadas por Mário de Andrade a inúmeros escritores do Brasil ao longo do século XX, argumentando que Mário havia escrito tantas cartas que talvez não seja sequer a metade de sua prolífera epistolografia o que até agora dele se conhece:

Como explicar-se essa paixão quase desesperada do grande Mário em escrever tanta carta aos seus amigos? Apenas para solicitar informações destinadas aos seus estudos e livros? Isso é normal a qualquer escritor. Todos temos absoluta necessidade de comunicação com os amigos escritores espalhados pelo Brasil afora e no estrangeiro. Cascudo foi outro que utilizou a correspondência como um dos seus mais poderosos instrumentos de trabalho. Toda a sua obra de erudição está pontilhada de informações colhidas para além dos livros, diretamente através de contatos com escritores amigos. Foi outro admirável epistológrafo (MELO, 1997, p. 157).

\footnotetext{
${ }^{44}$ Dentre esses, poderíamos citar nomes tais como: Gilberto de Melo Kujawski, Cassiano Nunes, José Carlos de Vasconcelos, Nilo Pereira, Félix Coluccio, Telê Porto Ancona Lopes, Claude Hulet, Edson Nery da Fonseca, Carlos Reverbel, Myran Fraga, Arthur Soffiati, Altimar de Alencar Pimentel, Acyr Castro, Bráulio do Nascimento, Osvaldo Lopes de Brito, Jácomo Mandatto, Hildegardes Vianna, Francisco Vasconcelos, Francisco Carvalho, José Lívio Dantas, Enéas Athanázio, Ascendino Leite, Oswaldo Lamartine de Faria, José Rafael de Menezes, Renato Pacheco, José E. Mindlin, Clóvis Meira, Marco Lucchesi e Geraldo Edson de Andrade (Cf. MELO, 1993b).
} 
Veríssimo se colocou nessa apresentação quase como um arauto, informando que em "um desses desígnios misteriosos da contingência humana, nós [Veríssimo de Melo] também nos inserimos, honrosamente, nesta bibliografia epistolar de Mário de Andrade. Organizamos, introduzimos e anotamos o volume Cartas de Mário de Andrade e Câmara Cascudo, ed. Villa Rica, Belo Horizonte, 1991”(Id. Ibidem, p. 160).

Relembrando o processo de publicação da respectiva obra, fala das condições de conhecimento das cartas e do árduo processo de publicação das mesmas; enfatizando que as respectivas cartas "vieram comprovar o que já prevíamos na orientação dos estudos de folclore do Mestre". Na análise de Veríssimo, a amizade de Mário resultou numa mudança de rumos extraordinária na orientação intelectual de Cascudo. Sem deixar de escrever sobre temas históricos e memorialísticos, Cascudo elaborou, a partir daquele ano da "carta terrível" de 1937, toda uma obra monumental em torno do folclore nordestino e brasileiro em geral, culminando em obras como Vaqueiros $e$ Cantadores (publicado em 1939), Dicionário do Folclore Brasileiro (publicado em 1954) e outros:

\begin{abstract}
Foi, portanto, extremamente benéfica a correspondência de Mário a Cascudo, apesar da dureza de certas expressões que utilizou naquele momento ao seu amigo natalense. Cascudo teve a humildade de aceitar a orientação, tornando-se o mais importante estudioso do folclore brasileiro em todos os tempos. É verdade que não se sabe a resposta de Cascudo àquela carta 'terrível' de 1937, pois a correspondência passiva de Mário só poderá ser divulgada a partir de 1995, quando completam os cinquenta anos de sua morte e conforme cláusula testamentária. Ela está preservada, em arquivo, no Instituto de Estudos Brasileiros, da USP (Id. Ibidem, p. 162).
\end{abstract}

Ao que se vê, Veríssimo de Melo vinculou Câmara Cascudo ao movimento modernista. Essa vinculação alcançou seus objetivos, pois a obra de Cascudo passou a ser explicada quase exclusivamente a partir do Modernismo. Entretanto, o objetivo inicial foi inserir Cascudo no panteão modernista, fazendo-o ocupar um lugar de destaque junto de escritores como Manuel Bandeira, Oswald de Andrade e, principalmente, Mário de Andrade, muitas vezes até apontando para uma subserviência de Cascudo em relação a Mário. Esse discurso modernista, pois, atribuiu mais importância ao já monumentalizado Mário de Andrade, conferindo-lhe o mérito de ter 
determinado os rumos das pesquisas de um dos maiores folcloristas brasileiros: Luís da Câmara Cascudo (SALES NETO, 2008, p. 69).

Concordamos com Francisco Firmino Sales Neto no que compete à sistemática ação de Veríssimo de Melo no intuito de monumentalizar a tese sobre o Cascudo modernista. Trouxemos novos elementos que confirmam as evidências por ele colocadas. Contudo, é relevante apontar a discordância quanto a sua argumentação, que coloca Marcos Silva (2003), como mero reprodutor dos enunciados que instituem o discurso sobre a temática em questão ${ }^{45}$.

Sales Neto argumenta que na Nota preliminar do Dicionário Crítico Câmara Cascudo (2003), Marcos Silva, antes de citar a pluralidade do pensamento de Câmara Cascudo, achou necessário destacar a amizade de Cascudo com Mário de Andrade e recordar a correspondência trocada entre esses dois escritores:

\footnotetext{
Cascudo foi amigo pessoal e colaborador de Mário de Andrade na viagem de pesquisa folclórica, musical e estética que o modernista paulistano fez a Natal na década de 1920, e os dois trocaram correspondências nos anos seguintes (...) (SILVA, 2003, p. XIII).
}

Só depois é que o organizador do dicionário faria referência às múltiplas facetas do pensamento cascudiano. Continuando sua crítica, Sales Neto, afirma que:

[...] mesmo distante do Rio Grande do Norte, Marcos Silva não consegue se desvencilhar da teia discursiva que articulou Cascudo ao Modernismo, nem questiona essa imagem, aceitando-a como dada. Assim sendo, o coordenador do referido Dicionário Crítico acabou reproduzindo enunciados que foram formulados sem relação direta com o contexto e a documentação da década de 1920. O fato de Marcos Silva ter repetido esse tipo de explicação deriva do grau de aceitação que o discurso modernista atingiu no Rio Grande do Norte e da eficaz construção do Luís da Câmara Cascudo modernista [...] (SALES NETO, 2008, p. 71).

\footnotetext{
${ }^{45}$ Esta crítica ainda será direcionada à produção de Humberto Hermenegildo (1995) e José Luiz Ferreira (2000), mas como neste ponto específico o autor inicia uma crítica em torno da relação de Cascudo com o Regionalismo Tradicionalista de Gilberto Freyre, deixaremos para nos ater ao debate no quinto capítulo da presente tese.
} 
Vemos que a crítica direcionada a Marcos Silva é um tanto quanto apressada. Pois, a nota introdutória do dicionário não é voltada apenas aos estudiosos da obra de Câmara Cascudo, mas principalmente ao grande público (é bom lembrar que acima de tudo, os livros são objetos de consumo, e devem de todo modo atingir aos fins de mercado, ou seja, proporcionar lucro aos autores, editores e livrarias); o autor procura chamar atenção do leitor não especialista para motiva-lo a conhecer um pouco mais sobre a vida e obra do escritor e etnógrafo potiguar. Nesse sentido, o referido texto não pode ser analisado na mesma condição dada à produção de Veríssimo de Melo. Até mesmo porque não toma a correspondência de Mário para Cascudo como objeto de análise, mas como figura de retórica. Marcos Silva não entende que Cascudo aprenda o ofício de folclorista e etnógrafo com Mário, mas que houve uma colaboração em pé de igualdade entre os mesmos. Em Allegro rubato: gêneros textuais e campos de saber em Câmara Cascudo (2013) ${ }^{46}$, por exemplo, vemos um argumento do autor que desmonta a avaliação de Sales Neto:

O Allegro rubato transforma Câmara Cascudo em comentarista e crítico de Câmara Cascudo, de talentoso polígrafo em inovador etnógrafo, pioneiro brasileiro na valorização da literatura oral e da cultura popular. O diálogo com Mário de Andrade, nesse campo, vai além de aprendizado com um grande mestre: evidencia a colaboração entre mestres que ensinam um ao outro os difíceis percursos através de modernidade e tradição. E as críticas de Mário a Vaqueiros e cantadores, que Luís não chegou a responder, entre elogios e divergências, deixam clara essa admiração recíproca (SILVA, 2013, p. 233).

Ao que podemos constar em nossos levantamentos, os estudos que ao longo dessas últimas décadas, fizeram referência à correspondência de Mário de Andrade e Câmara Cascudo de forma sistemática e/ou a reificação da tese em questão, foram: Byington (2000), Corção (2014), Gico (1998), Gomes (1999), Galvão (2010), Galvão (2012), Lima (2008) e Oliveira (2012). Trataremos deles de agora em diante.

\footnotetext{
46 O texto fora escrito originalmente em 2005, para o seminário "Câmara Cascudo e os saberes", originalmente integrado ao projeto "Memória do Saber", do CNPq (Ministério da Ciência e Tecnologia). Posteriormente, foi publicado em livro (com modificações) no ano de 2013. O seminário foi patrocinado pela FFLCH/USP, com o apoio da Biblioteca Municipal Mário de Andrade (onde foi sediado, numa homenagem aos laços de admiração e amizade que uniram Câmara Cascudo e o patrono da biblioteca) e das pró-reitorias de Cultura e de Extensão e Pesquisa da Universidade de São Paulo, sob a coordenação geral de Marcos Silva (SILVA, 2013, p. 11).
} 


\subsection{Segundo momento: Vânia Gico (1998)}

Vânia Gico (1998) propôs que os traços da correspondência entre Mário e Cascudo, como as demais trocadas por Cascudo e seus correspondentes, exibiam o corpo de ideias que permeavam suas obras e o cenário em que estavam envolvidos. Na avaliação da autora, as preocupações de Mário com a obra de Câmara Cascudo enfatizaram, principalmente, a escolha temática, sempre o convidando para "folclorizar", e o estilo da escritura, no qual a principal crítica era a pressa cascudiana para exprimir seu pensamento. Suas "reflexões apressadas" estariam contidas em seu próprio processo de criação dos textos, os quais eram elaborados de uma única vez, direto à máquina, sem serem lidos ou ressignificados. No reverso do conjunto, encontrava-se "a maior conquista dos modernos que era a despreocupação da literatura. Nada de frases bem acabadinhas, ritmos preconcebidos, adjetivos para encurtar frase direta" o que conferia à produção cascudiana um grande valor literário (GICO, 1998, p. 128-129; MA, 26-IX-1924, apud, CASCUDO, 2010a, p. 38).

Vânia Gico argumentou que numa análise geral da obra cascudiana, Mário teria sintetizado sua opinião em carta de 9 de junho de 1937, reforçando pontos já discutidos exaustivamente, inclusive, ao longo de sua convivência e da sua correspondência anterior com o amigo natalense. Para a autora, tal missiva foi tomada por intermédio da avaliação de Veríssimo de Melo como a "carta terrível”, e ao assegurar que a mesma vinha comprovar a "influência decisiva" de Mário na orientação dos estudos folclóricos de Cascudo, não poderia ser tomado como definitiva. Pois não se verificavam nas fontes elencadas para a elaboração de sua tese dados que confirmassem a proposição de "plano gigantesco de trabalho - no que se refere à obra folclórica de Luís da Câmara Cascudo por influência do Movimento Modernista”, como assegurava Veríssimo de Melo. Não teriam sido observadas outras configurações de plano temático de pesquisa e nem publicadas à época, as cartas de Cascudo a Mário de Andrade, para um confronto de informações. Gico defendia que só uma análise da correspondência disponível relativizaria bastante as questões levantadas por Veríssimo de Melo, visto que da primeira à última carta das cinquenta e seis missivas de Mário de Andrade a Câmara Cascudo, as questões mostradas são avanços e recuos de temática da realidade brasileira, assunto que preocupava a ambos. Isso vinha a realçar a importância da correspondência na obra de Cascudo, quando olhada numa visão de conjunto com as 
demais publicadas, e não "comprovar a influência decisiva" de Mário na orientação dos estudos folclóricos de Cascudo (GICO, 1998, p. 129-130).

Mesmo estabelecendo crítica as proposições de Veríssimo de Melo, a autora, argumentou que não restava dúvida em relação a que a sistematização do folclore na obra de Cascudo encontrou eco no movimento modernista e sintonia no pensamento de Mário de Andrade. Vânia Gico concluiu sua argumentação enfatizando que "é geralmente aceito que o Modernismo como estado de espírito dominante e criador, durou pouco menos de dez anos, terminando em 1930, mas deixou a base e o estilo de muitas escrituras que se esboçariam posteriormente, independente, de seguidores ou não, visto que era um estado de espírito universal", traços que caracterizariam o perfil cascudiano no exercício do processo criativo (ANDRADE, 1972, p. 187; GICO, 1998, p. 131-132).

Nisso, não se condiciona uma relação de subserviência, pois, como ressaltou a autora, Cascudo era rebelde às doutrinas vigentes, que para ele inibiam a criação, afirmando sempre que o melhor caminho para se anunciar pau-brasil era a liberdade. Desse modo, as influências do movimento modernista na textura, na metodologia e na proposta de temas da obra orientariam o que já vinha sendo gestado antes do contato com Mário de Andrade, inclusive no diálogo com Monteiro Lobato, que não fez parte do universo modernista (CASCUDO, 1924; GICO, 1998, p. 132, LAJOLO, 2013, p. 1431). Uma releitura de Alma Patrícia, por exemplo, indicaria o Modernismo nascendo também no Rio Grande do Norte, e não o orientando de fora, a posteriori, como autoritário guia unívoco. Na correspondência entre ambos que foi editada depois por Marco Moraes, Cascudo figura como um dos colaboradores invocados por Mário para a confecção de um fragmento da obra-prima modernista Macunaíma - peças do enxoval do herói (Cf. MA, 1-III-1927, apud, CASCUDO, 2010a, p. 123).

\subsection{Terceiro momento: Edna Maria de Sá Gomes (1999)}

No ano de 1999, Edna Maria Rangel de Sá Gomes, em sua dissertação de mestrado defendida no PPGEL/UFRN, intitulada Leitura das cartas trocadas entre Luís da Câmara Cascudo e Mário de Andrade, faz uma leitura das cartas de Mário e Cascudo em seu conjunto, destacando o teor das discussões evidenciado ao longo dos anos em que durou a correspondência; além, de contribuir grandemente com a revisão das missivas de Mário compiladas por Veríssimo; ainda mais por ter apresentado ao 
público acadêmico o teor das cartas enviadas por Cascudo a Mario de Andrade, que até aquele momento, encontravam-se, como toda a correspondência passiva de Mário, lacrada no IEB/ USP.

Tratando dos itinerários de sua pesquisa, Edna Maria afirmou que quando decidiu trabalhar com o respectivo tema, se deparou de imediato com algumas dificuldades: a única publicação com as cartas de Mário de Andrade a Câmara Cascudo (ANDRADE, 1991) estava esgotada e não encontrava o livro em lugar algum; os originais das cartas encontravam-se no memorial Câmara Cascudo, que estava fechado para reforma e sem data para reabertura. O livro, então esgotado, foi-lhe cedido por seu orientador, o Dr. Eduardo de Assis Duarte, e ao começar a análise, a pesquisadora detectou mais um problema: em algumas partes, o texto lhe parecia confuso, truncado, faltando algo. Teve, portanto a iniciativa de marcar uma entrevista com o organizador do referido livro, o professor Veríssimo de Melo; informando que, apesar de todo o cuidado que ele teria tido, poderiam existir falhas na transcrição das cartas em decorrência da letra difícil de Mário de Andrade, do péssimo estado de conservação de algumas cartas e, de certo modo, até à pressa com que ele fez esse trabalho de transcrição, que muitas vezes, pode ser penoso (GOMES, 1999).

Recorreu à época, à Diretora do Memorial Câmara Cascudo, Daliana Cascudo Roberti Leite, que gentilmente lhe permitiu, como a seu amigo Professor Humberto Hermenegildo de Araújo, ter acesso aos originais, nos quais pôde comprovar suas suspeitas em relação às falhas existente na transcrição das cartas. Fez a revisão de todas elas, corrigindo trocas e omissões de palavras e trechos, na medida do possível; pois existiam algumas missivas tão deterioradas, faltando pedaços e com tinta passando de um lado para o outro do papel, que não foi possível corrigir nem recorrendo a uma lupa e, nestes casos, a autora ficou com o texto do livro publicado. Para o bom desenvolvimento da dissertação, a autora achou por bem usar o texto corrigido e inserir notas sempre que se fazia necessário, fosse para mostrar que mudou ou acrescentou alguma palavra, trecho da carta, para explicar, esclarecer qualquer coisa sobre fatos, pessoas, revistas e jornais citados por Mário de Andrade. Depois de toda revisão realizada, achou necessário não só usar o texto corrigido como base principal de seus estudos, mas os inseriu no anexo de sua dissertação.

Também fez o mesmo com as cartas de Cascudo enviadas para Mário, obteve por intermédio de autorização de Daliana Cascudo uma autorização para ter acesso, pesquisar, copiar e usar na respectiva dissertação as cartas arquivadas no IEB-USP. 
Em linhas gerais, Edna, faz em sua dissertação um apanhado teóricometodológico a respeito dos estudos sobre a correspondência, para em seguida realizar uma leitura sobre os temas centrais tratados ao longo da pesquisa desenvolvida em três capítulos. No primeiro capítulo, Anos 20: Mário e Cascudo se respondem: um canta de lá, que eu conta de cá, aborda a década indicada, mostrando os objetivos de cada um dos dois intelectuais com esta correspondência e tratando um pouco do Cascudo poeta. No segundo capítulo, Anos 30: desafios - política e pesquisa sob tensão, que se restringe à década de 30, aborda a questão das transformações políticas e ideológicas, comentando a respeito da participação de Mário de Andrade à frente do Departamento de Cultura da Prefeitura de São Paulo, como da situação econômica de Câmara Cascudo e dos muitos embates pelos quais ele passa durante esta década. O terceiro capítulo Anos 40: Mário poda; Cascudo mostra seus frutos versa sobre a década de $40 \mathrm{com}$ as poucas cartas disponíveis, apenas 5 de Mário de Andrade e 14 de Câmara Cascudo, o que, em sua concepção, mostra pouco do escritor paulista, mas permite perceber um Cascudo muito mais seguro e atuante no folclore, tanto na teoria como na prática.

A autora entende que o Modernismo no e do Rio Grande do Norte se dá principalmente através da correspondência entre Mário e Cascudo, afirmando que essa correspondência transformara-se de documento em monumento da história cultural do Modernismo no Rio Grande do Norte. Detectou ainda um eixo central e alguns eixos auxiliares que sustentam tal correspondência, quais sejam: a divulgação das ideias modernistas pelo Nordeste e as pesquisas etnográficas, como eixo central, e a criação de uma língua nacional, a preservação da cultura popular nordestina, a poesia cascudeana, as questões político-ideológicas, como alguns dos eixos auxiliares apontados através de sua pesquisa (GOMES, 1999, p. 44-45).

Em nossa avaliação, apesar da grande contribuição do conjunto das 56 cartas de Mário de Andrade e das 93 cartas de Câmara Cascudo ${ }^{47}$ (árduo trabalho de transcrição dos documentos, devido ao estado dos manuscritos e datiloscritos), o texto não traz maiores aprofundamentos na análise da documentação. $\mathrm{O}$ momento em que a autora aponta a possibilidade de uma discussão mais instigante acaba ficando em aberto, não a problematizando:

\footnotetext{
${ }^{47}$ Posteriormente, foram superadas pela edição organizada por Marcos Antonio de Moraes (2010), que nos traz 65 cartas de Mário ( 9 cartas inéditas) e 94 de Cascudo (1 carta inédita).
} 
É mais uma citação longa ${ }^{48}$, porém necessária, porque comprova a existência de um Cascudo poeta - e senão um bom poeta, como queira Mário de Andrade, ou senão um poeta moderno, mas um poeta - e de, pelo menos, um livro de poesia escrito por ele, que nunca chegou ao conhecimento público. Comprova também o incentivo do amigo paulista que discorre sobre poesia e obra de arte de forma brilhante, mas simples e direta. E aqui fica uma pergunta: onde está este livro? Sobreviveu ao tempo? Seria interessante uma pesquisa no sentido de resgatá-lo ou recuperá-lo, pelo menos em parte. Até mesmo para descobrir que ele não foi, também, poeta, se for este o caso (GOMES, 1999, p. 58).

Adiante, veremos que este intento será realizado por Dácio Galvão em sua tese O poeta Câmara Cascudo: um livro no inferno da biblioteca (2012). Não compreendemos o fato do trabalho de Edna não ter sido publicado em livro, principalmente, frente à relevância já dada às cartas de Mário ao longo da década de 90. Seria a possibilidade para dar-se voz ao posicionamento de Cascudo, no conjunto da correspondência por ele recebida à época.

\subsection{Quarto momento: Silvia Ilg Byington (2000)}

O trabalho de Byington (2000) teve por objetivo aprofundar a relação de colaboração intelectual e amizade pessoal entre Luís da Câmara Cascudo e Mário de Andrade, buscando, em suas trajetórias intelectuais e vasta produção bibliográfica, compreender os distintos caminhos tomados para responder à questão da identidade nacional. A dissertação teve como corpus documental privilegiado e elemento de delimitação as cartas trocadas entre os dois autores entre 1924 e 1944. Conforme comentamos anteriormente, a autora indica em nota a sistemática no uso das fontes consultadas, ou seja, a edição das cartas de Mário enviadas a Cascudo, organizada por Veríssimo de Melo, e a compilação realizada por Edna Maria:

\footnotetext{
${ }^{48}$ Refere-se à transcrição da carta enviada por Mário a Cascudo em janeiro de 1926: (...) "Isso me lembra o que você fala na sua carta sobre a poesia de você. Você vai-me tirar imediatamente do 'inferno da biblioteca' como escreveu, os seus livros de versos e vai relê-los e trabalha-los. (...) Você está na obrigação de me mandar logo os seus versos pra que eu os leia, tenho vontade deles. E mude sua opinião sobre maneira de fazer obra-de-arte que sobre este ponto de... parir só e não educar depois está positivamente errada" (MA, I-1926, apud, CASCUDO, 2010a, p. 84-85).
} 
(...) A série de cartas de Mário foi revista por Edna Maria de Sá Gomes, aluna do Programa de Pós-Graduação do departamento de Letras da UFRN. Na revisão, foram constatadas inúmeras trocas e omissões de termos e sentenças na publicação citada a cima [a de Veríssimo de Melo]. Por este motivo, aqui é utilizado o texto revisto e gentilmente cedido por ela. Nas notas seguintes deste texto, será informada a página onde se encontra a carta citada na publicação e, em seguida, a página da revisão, indicada com a sigla E.G. (BYINGTON, 2000, p. 16).

Diferentemente do trabalho de Edna Maria, que propôs uma leitura e apontamentos dos temas gerais da correspondência de Mário e Cascudo, Silvia Byington toma as cartas como "lugar de sociabilidade", por registrarem o movimento dialógico de construção das múltiplas identidades intelectuais dos autores, acentuando suas semelhanças e diferenças na relação. Também fez uso das séries de crônicas escritas por Mário e por Cascudo por ocasião da viagem que fizeram juntos em 1929. O eixo do trabalho foi investigar, através da relação de amizade e de colaboração entre Cascudo e Mário, a construção das questões intelectuais comuns aos dois autores bem como as diferenças existentes entre ambos. A autora considerou que as fortes individualidades dos mesmos expressam facetas das principais questões culturais de seu tempo, com o propósito de aprofundar a história cultural do Modernismo no Brasil.

Byington não segue a mesma linha de argumentação proposta por Veríssimo; em sua concepção, a avaliação de Veríssimo sobre a famosa carta de junho de 1937 - em que Mário teria convertido Cascudo ao tema do folclore - não se sustenta. Para a autora, Mário mais uma vez sublinha as diferenças entre seus estudos e os de Cascudo, desta vez expressas como críticas contundentes. Não mais valorizava a singularidade que o fazia um dos "heliótropes", conhecedores da matéria folclórica, mas assinala seus "erros" - sublinhando, portanto, como acertos os seus próprios critérios de validade do saber etnográfico, inserindo-se, assim, no movimento de formação do discurso científico da antropologia social (BYINGNTON, 2000, p. 150-151).

O texto de Silvia Byington, no que compete ao debate historiográfico em torno da correspondência de Mário e Cascudo, aponta possibilidades interpretativas que rompem com a ideia de influência e determinação de Mário na produção intelectual de Cascudo. Embora contextualize o debate dos escritores durante a época do Modernismo, não coloca este aspecto como fim explicativo. Dispondo a documentação para ser 
analisada em outras lentes, vemos que a autora possibilitou a compreensão deste aspecto biográfico a ser pensado a partir do processo de formação da identidade nacional do país, como da formação do campo de estudo das ciências sociais, por intermédio dos estudos do folclore e da etnografia. O hiato colocado pela pesquisa de Byington será quebrado e a chave interpretativa do Cascudo modernista será retomada durante os anos de 2008 e 2014, como veremos a seguir.

3.6. Quinto e último momento: Aluízio Lins de Oliveira, Claudio Augusto Pinto Galvão, Dácio Tavares de Freitas Galvão, Matheus Silveira Lima e Mariana Corção (20082014)

Neste momento do texto, iniciaremos nossa discussão com o artigo Percurso intelectual de Luís da Câmara Cascudo: Modernismo, folclore e antropologia de Matheus Silveira Lima (2008). Depois do estudo proposto por Byington (2000), foi o primeiro a tratar sobre a relação de Cascudo com o Modernismo, o autor entende que essa relação, foi determinante para a sua relação com os campos de conhecimento do folclore e da antropologia.

Na opinião de Matheus Lima, durante a década de 20, Cascudo já se encontrava envolvido com o amplo movimento de questionamento da realidade brasileira, expresso entre outras manifestações na realização da Semana de Arte moderna de 1922. Argumentou ainda que Cascudo esteve atento a essas transformações, podendo isso ser confirmado por correspondência com Mário de Andrade, num momento em que escrevia, inclusive, alguns poemas de inspiração modernista ${ }^{49}$ (LIMA, 2008, p. 175176).

Ao adiantar de suas proposições, Lima faz certa ponderação, afirmando que:

Outra possibilidade que pode ser considerada é a de se procurar entender a obra de Cascudo como mantendo uma certa distância das idéias de seu tempo, pois embora ele se envolvesse pessoalmente com os movimentos de cunho político e cultural, como o Modernismo, o regionalismo, ou o integralismo, é difícil apontar uma obra de

\footnotetext{
${ }^{49}$ Trata-se dos poemas: Shimmy (CC, 10-VI-1925, apud, CASCUDO, 2010a, p. 45-46); Os três poemas não nomeados que tratam do sertão potiguar (CC, 4-IX-1925, Id. Ibidem, p. 60-62); e Não Gosto de sertão verde (CC, 25-V-1926, Id. Ibidem, p. 107). Eles foram analisados no corpus documental que compôs o objeto de estudo da tese de Galvão (2012). Avaliaremos o respectivo texto logo a seguir.
} 
O autor aponta que a emancipação das ideias de Cascudo seria expressa através do desvio às correntes metodológicas em evidência, e da inovação na manipulação das informações dos meios de instrumentalizar sua obra (GICO, 1998, p. 100; LIMA, 2008, p. 180). Concluindo esta argumentação, Lima passa a realizar uma sinopse de algumas obras de Câmara Cascudo, representativas no campo do folclore, tais como Vaqueiros $e$ Cantadores, Geografia dos Mitos Brasileiros e o Dicionário do Folclore Brasileiro para centrar na análise da obra Civilização e Cultura.

No ponto máximo de seu artigo, Lima afirma que o que se pode inferir dessa arriscada tentativa de interpretação antropológica da obra de Cascudo é que o processo de transmissão cultural, na perspectiva cascudeana, é bastante singular, podendo ter suas características variando a cada caso. Assim, o uso de um instrumental teórico e metodológico deve se adequar ao objeto estudado. O autor argumenta por fim que os estudos folclóricos e antropológicos apresentam como característica principal as contribuições que recebeu das diversas correntes de pensamento antropológico, mas também das venturosas contribuições que o autor dá a essa disciplina, através de suas etnografias e de seus ensaios interpretativos (LIMA, 2008, p. 187-188).

No ano de 2010 Claudio Galvão, defendeu a tese Alguns Compassos - Câmara Cascudo e a Música (1920/1960), o autor demonstrou que embora Cascudo não tenha escrito nenhum livro tratando especificamente sobre música, verifica-se em seus escritos uma grande preocupação pelo assunto e constantes menções, estudos e comentários. Detalhes de sua biografia indicam como a música estava presente em sua vida e, principalmente, o quanto se dedicou ao estímulo aos musicistas de sua terra e à ajuda e incentivo às instituições musicais da cidade de Natal. A atividade de Câmara Cascudo como musicólogo é praticamente desconhecida, pois este aspecto de sua vida ainda não havia sido devidamente estudado. O propósito da pesquisa de Galvão foi trazer um pouco de luz sobre o assunto. Nesse sentido, o autor demonstrou que no decorrer do diálogo epistolar estabelecido entre Câmara Cascudo e Mário de Andrade, muitas foram às passagens que trataram sobre a respectiva temática. A música é pensada nas questões que dizem respeito aos aspectos da História Geral da Música, com enfoque em alguns compositores como Brahms e Wagner; também é abordada questões em torno do modernismo e musicalidade brasileira, por intermédio de questões em torno da 
música, folclore e etnografia. Embora a correspondência de Cascudo e Mário não seja o foco de sua análise, a leitura proposta por Galvão (2010), traz novos elementos que transpõe a lógica de interpretação da tese do Cascudo modernista (GALVÃO, 2010, p. 291-323).

Em Erudição e cultura popular na atividade intelectual de Luís da Câmara Cascudo, Aluísio Lins Oliveira (2012) buscou realizar a descrição de alguns aspectos da vida intelectual de Câmara Cascudo. Em sua análise, Oliveira se concentrou em alguns documentos culturais relacionados à perspectiva intelectual de Cascudo (produzidos pelo próprio ou sobre ele), buscando apontar que essas produções intelectuais, encerraram no autor uma perspectiva comum de fundo biográfico presente nas questões sócio-culturais que envolveram a intelectualidade brasileira no decorrer do século XX.

Nesta tese, quando tratou das Condições culturais de uma relação entre o erudito e o popular (capítulo 1), Aluísio Oliveira dedica uma longa secção para tratar de Cascudo e Mário de Andrade e já na abertura, fala da importância da amizade de Mário para "o andamento do trabalho intelectual de Cascudo":

A amizade com Mário de Andrade foi fundamental para o andamento do trabalho intelectual de Cascudo. Inicia-se através de envio de cartas. A correspondência entre Mário de Andrade e Cascudo se inicia em 1924 e se estende até o ano de 1944, embora já nos anos finais da década de 1930 ela seja bem diminuta em comparação aos períodos anteriores. Mário de Andrade escreve uma primeira carta a Cascudo em agradecimento pelo artigo que este publicou sobre ele no jornal A Imprensa, em Natal. Mário diz que já conhecia Cascudo de artigos publicados na Revista do Brasil. Gostou bastante do artigo com o título de Aboiador. Conhecia Cascudo da leitura desses artigos (OLIVEIRA, 2012, p. 72)

Como é possível perceber, Oliveira retifica sem problematização o discurso de Veríssimo em torno da correspondência de Cascudo e Mário de Andrade. Vejamos como exemplo as passagens seguintes:

Na correspondência se encontra uma crítica de Mário de Andrade para que Cascudo redefina suas temáticas de pesquisas e ofereça mais atenção à vida social e cultural que ele pode encontrar na sociedade onde vive. Nos livros de Cascudo nas décadas de 1920 e 1930 as 
temáticas dominantes eram a crítica literária no Rio Grande do Norte, aspectos culturais da região Nordeste, particularmente do sertão, e biografias personalistas de personagens da monarquia como Conde d'eu e o Marquez de Olinda (...)

O primeiro organizador das cartas de Mário a Cascudo, edição de 1991, apontou uma carta de Mário em 1937, como um elemento definidor nas mudanças de rumo do trabalho intelectual de Cascudo e sua especialização folclorista. Resultando na publicação em 1930 do livro Vaqueiros e Cantadores. As apreciações críticas de Mário de Andrade em relação ao que foi produzindo Cascudo são constantes na correspondência e a questão não pode ser vista como um ato isolado de um intelectual que provoca em outro a elaboração de um livro (...) (OLIVEIRA, 2012, p. 76-77).

O autor não deixa claro quais elementos são esses e de como retificam os argumentos que pretende defender em sua tese. Estabelece uma comparação entre Mário e Cascudo que demonstra certo desconhecimento da obra dos escritores e uma tentativa precipitada de encaixa-los num esquema de explicação preestabelecido e até preconceituoso, não trazendo uma contribuição expressiva ao debate:

Em Mário de Andrade e Cascudo encontramos modalidades de discurso sobre a cultura popular. Câmara Cascudo desenvolveu uma perspectiva de discurso do popular que se caracteriza pelo fato da não historização dos exemplos culturais pesquisados, pela desconsideração dos outros fatores sociais da vida dos agrupamentos produtores dessa cultural, pela fragmentação dos diversos componentes (uma dança, uma música, um registro de literatura oral, etc.), tudo dentro de uma estruturação enciclopédica e dicionarizada. Esse tipo de perspectiva acabou servindo mesmo para entreter as atividades desses intelectuais e suas justificativas sociais. Mário de Andrade, no entanto, fez grandes esforços de fundamentação cultural para o Brasil e sempre procurou fazer os ligamentos de um fato cultural com diversas outras instâncias sociais. Mário de Andrade terá outra forma de declaração de 'amor ao povo' (...) (OLIVEIRA, 2012, p. 78).

Em continuidade ao ano de 2012, temos a tese de Dácio Galvão, que num recorte pontual, defendeu que Luís da Câmara Cascudo pode ser categorizado como um dos principais aglutinadores de interesses de produções literárias modernas no Rio 
Grande do Norte. Aponta que a atividade intelectual de Cascudo nos anos de 1920 resultou em edição de textos, divulgação de periódicos, além da escrita de livros e de uma vasta produção epistolográfica, embora só venha a se ater em parte da correspondência entre Mário e Cascudo, em especial as realizadas durante a década de 20 - momento em que os dois trataram sobre a elaboração de poemas modernistas. Galvão entende que a presença de Cascudo nesse cenário local é importante para aquilo que podemos entender como Modernismo. Na opinião do autor, o contato com Mário e outros poetas contemporâneos o colocaram na trajetória poética, sendo ele, no ano de 1927, o editor de Jorge Fernandes, poeta de um único livro de poemas determinantes para a linguagem moderna em terras potiguares. Mostra ainda que Câmara Cascudo escreveu alguns poucos poemas e examinou a possibilidade de publicá-los em livro autoral, Brouhaha ou Caveira em campo de trigo; a partir desses resultados poéticos, ganharia elogios e observações de Mário de Andrade e espaços jornalísticos generosos concedidos por Joaquim Inojosa em Pernambuco (GALVÃO, 2012, p. 9).

Quando tratávamos da dissertação de Edna Maria, fizemos menção a sua iniciativa de seguir as pistas da temática sobre a relação de Cascudo com a poesia, o que fica explicito na introdução desse trabalho de Galvão:

\footnotetext{
Em sua dissertação de mestrado, sobre a correspondência entre Cascudo e Mário de Andrade, Edna Maria Rangel de Sá chama a atenção para este interessante aspecto da produção literária cascudeana, o qual foi valorizado pelo amigo paulista por meio do incentivo à reescritura. Segundo Edna, Cascudo seria, senão um bom poeta, como queria Mário de Andrade, ou senão um poeta moderno, mas um poeta (...) (Id. Ibidem, p. 9).
}

Galvão também interpreta que a amizade de Cascudo com Mário seria um estímulo às pesquisas e caminhos a serem percorridos pelo polígrafo potiguar. Além disso, enxerga também a presença de elementos díspares que vão do regionalismo freyreano ao futurismo de Marinetti. Partindo de tais considerações, o autor tem como principio a leitura do texto literário como fonte primordial de questionamentos, numa metodologia que se tece no entrecruzamento de visões integrativas do fenômeno literário, com aberturas interdisciplinares para o campo da história e das ciências sociais. Por esta razão, todos os capítulos da tese tiveram como eixo central a análise 
exaustiva dos poemas selecionados para o corpus da pesquisa ${ }^{50}$. O objetivo da análise foi verificar a contribuição do poeta ao movimento modernista brasileiro em sua fase inicial de abrangência nacional, demonstrar a força da poesia como polo atrativo da percepção de mundo intelectual que produziu uma das mais importantes obras da cultura brasileira ao longo do século XX e de forma às vezes assistemática. Para Dácio Galvão, essa atração de Cascudo pela poesia poderia significar uma ruptura em relação ao comportamento científico dominante na modernidade (Id. Ibidem, p. 10-13).

O trabalho traz nova contribuição à fortuna crítica de Câmara Cascudo, porque põe em discussão o gênero literário poético revelando um estudo promissor sobre o aprendizado inicial de Câmara Cascudo como interprete, produtor e consumidor de poesias. Ampliando por fim, o conhecimento sobre década de 20 na produção intelectual de Câmara Cascudo, com desdobramento em seus escritos posteriores.

A tese Câmara Cascudo, o "Provinciano Incurável": Desvendando os caminhos de História da Alimentação, de Mariana Corção (2014), buscou destrinchar os caminhos que conduziram Cascudo na escrita de sua história da alimentação, de modo a perceber aquela problemática para além de seu conteúdo informativo. Aponta os diversos elementos que contribuíram para a análise, como o lugar social de Cascudo, seu diálogo com intelectuais que se voltaram para a questão como Josué de Castro e Gilberto Freyre, o contexto de expansão da indústria alimentícia no Brasil e do discurso nutricionista. Embora aborde as experiências alimentares de Cascudo no continente africano, destacou a relevância da cozinha portuguesa, que em sua opinião deu unidade à variedade regional alimentar. Corção realiza um levantamento sobre o legado da produção acadêmica existente sobre a obra de Câmara Cascudo, com ênfase nos estudos que tomaram como referência a obra em questão. O mais significativo, para a presente pesquisa, é que a autora, quando procura estabelecer os percursos que deram condição de Cascudo redigir a obra, este tenha que passar pelos vinte anos de correspondência com Mário de Andrade. Neste ponto, Corção não coloca nada de novo, apenas reproduz sinteticamente o discurso preestabelecido e aqui já amplamente problematizado. Também demonstra desconhecer o processo de publicação e circulação da correspondência, atribuindo o projeto em questão como tendo sido originalmente

\footnotetext{
${ }^{50}$ Além dos poemas já citados na nota anterior, o autor irá tratar de outros poemas de autoria de Câmara Cascudo e que não foram divulgados na correspondência de Mário e Cascudo: "Brasil de Madrugada", "Banzo" e "Lundum de Collen Moore", publicados em revistas modernistas da época; também no corpus da análise, encontramos o poema "Kakemono", dedicado a Joaquim Inojosa Cf. (INOJOSA, 1968, p. 105), a tradução de Cascudo para três poemas de Walt Whitman e o texto cascudeano intitulado "A poesia é a quinta dimensão do mundo" Cf. (GALVÃO, 2012, p. 13)
} 
concebido apenas por Marcos Antonio de Moraes, esquecendo-se portanto de Veríssimo de Melo (CORÇÃO, 2014, p. 37-40).

Neste momento, podemos constatar que durante anos vários estudos tomam a experiência modernista de Cascudo como eixo explicativo para toda sua obra. Como bem colocou Bourdieu (2006), essa vida organizada como uma história transcorre segundo uma ordem cronológica que também se quer lógica, desde um começo, uma origem, no duplo sentido do termo, de ponto de partida, de início e princípio, de razão de ser, de causa primeira, até seu termino, como um objetivo intransponível (BOURDIEU, 2006, p. 184).

Essa coerência biográfica é sem sombra de dúvidas fruto desse processo de monumentalização imposto à correspondência entre Mário e Cascudo. Aqui, não pretendemos propor que esses documentos não existiram, mas frisar que o que sobrevive na história não é o conjunto daquilo que existiu no passado, mas uma escolha efetuada quer pelas forças que operam no desenvolvimento temporal do mundo e da humanidade, quer pelos que se dedicam à ciência do passado e do tempo que passa, os historiadores (LE GOFF, 2003, p. 525). E quando falamos de "historiadores" nos referimos também aos diversos pesquisadores dos campos das letras e das ciências sociais que contribuíram para a legitimação da respectiva tese.

Por muito tempo, a legitimação da tese sobre o Cascudo modernista foi tida como hegemônica devido à interpretação posta por Veríssimo, além do não conhecimento de outras correspondências e da relação de Cascudo com outros correspondentes com uma relevância no cenário intelectual e político tal qual teve Mário de Andrade. Afirmamos em outro momento deste capítulo que o Instituto Ludovicus - Câmara Cascudo está disponibilizando cerca de 15000 cartas, o que com certeza fomentará uma série de novos estudos e interpretações sobre a obra de Luís da Câmara Cascudo. Não temos de forma nenhuma a intenção de exaurir esse debate, mas certamente, de colocá-lo em novos termos.

Como ponto de partida, faremos uma discussão em torno do levantamento da correspondência de alguns interlocutores que também se corresponderam com Cascudo durante a época em que ele trocava cartas com Mário de Andrade; e que demonstra que Cascudo embora estabelecesse uma rede de sociabilidade modernista em sua correspondência, também estabeleceu redes sobre outros assuntos como: história, crítica literária, ideologia política, campo editorial e mais diversos temas. Iremos nos ater 
agora às correspondências enviadas por Monteiro Lobato (1920-1944), Rocha Pombo (1920-1928), Pedro de Orleans Bragança (1924-1938) e Guilherme Auler (1942-1962).

\subsection{Outras redes, novos sentidos: a correspondência passiva de Cascudo}

Mais que qualquer outro grupo social, os intelectuais se caracterizam pela troca de informações, ideias e opiniões através de suas correspondências. O mundo das letras é marcado pela troca de bilhetes, cartas, textos e livros. Esboça-se, assim, através da escrita epistolar, parte de sua rede de sociabilidade, permitindo a (re) inserção de suas ideias em seu ambiente social e cultural; o que é um meio eficaz para se compreender os papeis que tanto a amizade e a solidariedade, como a hostilidade e a rivalidade desempenham em sua produção, como podemos ver na carta de Mário de Andrade enviada para Cascudo em 21 de abril de 1926:

\footnotetext{
Mando pra você um artigo de sátira contra o Lobato que vai deixar você tiririca. Não se zangue comigo não. Bem reconheço que lobato tem valor porém andou falando umas merdices sobre os 'futuristas' e por isso é que desanquei nele. Como o artigo saiu hoje ainda não sei se fará escândalo e terá resposta. Depois te conto o resto (MA, 21-IV1926, apud, CASCUDO, 2010a, p. 100).
}

Embora esparsa em sua amostragem, temos no conjunto das correspondências enviadas a Cascudo o elenco de alguns dos "homens de letras" e "de ciência" que integraram o estreito mundo da intelectualidade brasileira nos primeiros anos do século XX. O estudo das estratégias de sociabilidade utilizadas por esse grupo torna-se assim uma via fértil para a definição do próprio conceito de intelectual da época, na medida em que, ao invés de se tentar estabelecer os limites do campo intelectual, busca-se compreender como este funciona. Mais do que tentar esboçar suas fronteiras externas, pretende-se investigar como se estabelece uma especificidade intrínseca a ele. Não se trata de determinar quem pode ou não ser considerado intelectual e, sim, de perceber quem são as pessoas que circulam nos meios literários, culturais e científicos e as funções que elas ocupam e por qual razão Cascudo pretendeu estabelecer correspondência com os mesmos (VENÂNCIO, 2004, p. 113-116).

No contexto em questão, as correspondências de Câmara Cascudo, se destacam como lócus privilegiado de análise histórica, pois registram uma forma de acumulação 
privada que possui como marca identitária o nome do titular. Elas são aqui revalorizadas não porque representem um conhecimento "mais verdadeiro", e sim porque asseguram a possibilidade de mudanças de foco, a compreensão de configurações intelectuais múltiplas, que exibem uma memória específica. A análise desse tipo de fonte permite a compreensão das relações estabelecidas entre as representações subjetivas do agente em questão (Luís da Câmara Cascudo) e a memória que se constrói sobre ele através do recorte estabelecido, memória esta que vai na contramão da identidade modernista elaborada através da correspondência de Cascudo com Mário de Andrade que discutimos até agora (VENÂNCIO, 2001, p. 27).

\subsubsection{Monteiro Lobato (1920-1944)}

No decorrer de nossa análise, vimos que houve grande valorização da carta de 9 de junho de 1937 enviada por Mário a Cascudo. Missiva que foi batizada por Veríssimo, como "carta terrível", que em sua concepção teria posto Cascudo no itinerário das pesquisas e estudos sobre o folclore. Certamente, não só Veríssimo, mas alguns outros estudiosos deixaram passar despercebido um dado posto já na primeira carta enviada por Mário, nela, saudando e agradecendo Cascudo pelo artigo " $O s r$. Mário de Andrade”, publicado no jornal A' Imprensa em 11 de junho de 1924, diz que o nome Cascudo, ficou em sua lembrança dum artigo lido na Revista do Brasil:

\footnotetext{
Você há de permitir à minha modéstia que confesse a alegria que me deu o seu artigo. Muito obrigado. Sempre traz conforto à gente ver que de todo não é improfícua a empreitada que se deu de renovação, prolífera principalmente em desgostos, lutas, calúnias, desilusões. Já o conhecia. O seu nome ficou-me dum artigo lido na Revista do Brasil. (...) (MA, 11-VI-1924, Apud, CASCUDO, 2010a, p. 33).
}

Durante os anos de 1920 e 1923, o escritor potiguar Luís da Câmara Cascudo publicou quatro textos na Revista do Brasil, editada em São Paulo por Monteiro Lobato. O sertão nordestino se configura como a principal temática abordada nesses textos. Sendo eles: "A humanidade de Jeca Tatu” (setembro de 1920), "O aboiador" (julho de 1921) “Jesus Cristo no sertão" (julho de 1922) e "Licantropia sertaneja” (outubro de 
1923) ${ }^{51}$. Partindo dos pressupostos apresentados por José Luiz Ferreira (2013), se olharmos esses textos do ponto de vista dos acontecimentos ocorridos na vida intelectual do escritor e no panorama literário e cultural brasileiro, nos momentos que se seguem aos anos de 1920, perceberemos que os elementos da tradição sertaneja, presentes nos escritos de Câmara Cascudo, antecedem a efervescência das discussões que encaminhavam o debate da intelectualidade brasileira para o detalhe da cor local.

Nacionalmente, esse discurso tomou maior consistência nos anos que se seguem à famosa semana de 1922 e, no caso nordestino, mais especificamente, na retomada do processo de retradicionalização da região orientada pelo movimento regionalista de Recife a partir de 1926. É importante lembrarmos que Cascudo naquela época, era um jovem com apenas vinte e dois anos de idade e que estava, portanto, iniciando uma vida intelectual. Mesmo assim, ele já despontava como um dos principais atores na cena cultural da provinciana cidade do Natal. Proprietário de um dos principais jornais da cidade, A Imprensa (1914-1927), ele reunia em torno de si os nomes mais expressivos da intelectualidade natalense e com eles, discutia as ideias estéticas e culturais postas nos cenários nacional e mundial. Por intermédio de Cascudo, a capital potiguar tomou conhecimento de e discutiu os acontecimentos em torno da Semana de Arte Moderna de São Paulo; e foi com sua mediação que escritores de vários estados como Pernambuco e Rio de Janeiro foram lidos na cidade, como ainda escritores locais tiveram suas obras divulgadas em outros ambientes pelo país afora, como foi o caso da obra de Jorge Fernandes.

Surgida naquele contexto de renovação, mas anterior ao período das revistas consideradas "modernistas" pela historiografia, a Revista do Brasil figurou como um veículo de expressão literária que foi capaz de congregar elementos que revelaram as várias faces do heterogêneo cenário da cultura nacional. No comando da revista, Monteiro Lobato empreendeu a criação das diretorias regionais, com o objetivo de agilizar a divulgação da revista além das fronteiras paulistas. Para assumir esses cargos,

\footnotetext{
${ }^{51}$ Neste capítulo, não nos ateremos à análise dos respectivos textos. Para um melhor conhecimento dos mesmos, Cf. (FERRERA, 2013, p. 125-147). Em nota a carta de Mário de Andrade de 11 de junho de 1924, Marcos Antonio de Moraes aponta que Mário possuía três volumes da Revista do Brasil com os respectivos textos, a exceção do "A Humanidade do Jeca tatu". Cf. (CASCUDO, 2010a, p. 33). Sobre este aspecto, Durval Muniz (2013c) comentou que ao contrário da versão oficial de sua biografia, a projeção nacional do nome de Câmara Cascudo não se dará no seio do movimento modernista e através de sua ligação com Mário de Andrade; nem foi apenas por causa deste encontro e das admoestações que Mário teria feito ao seu trabalho, através da famosa carta de 1937, que Cascudo resolveu escrever sobre folclore: foi através de sua relação com Monteiro Lobato que publicou seus primeiros escritos sobre folclore, como podemos ver acima; foi na editora de Lobato que Cascudo veio a publicar seu primeiro livro de projeção nacional, Histórias que o tempo leva... (ALBUQUERQUE JR., 2013c, p. 111-112).
} 
o editor convidou pessoas de renome no mundo literário. Dentre esses, se destacavam os diretores José Maria Bello (RJ), Mário Sette (PE), Costa Pinto (BA), etc. No Rio Grande do Norte, o cargo de diretor estadual da revista coube a Henrique Castriciano, personagem que desfrutava, naquele momento, na capital potiguar, de uma considerável reputação intelectual sendo conhecido como o "Príncipe dos poetas". A partir dessa influência exercida por Henrique Castriciano, o nome do jovem e promissor intelectual Câmara Cascudo foi incluído entre os colaboradores daquela que foi considerada a principal publicação cultural do país da época (FERREIRA, 2013, p. 125-129).

Neste ponto, devemos destacar que de acordo com Giselle Martins Venâncio (2007), as revistas literárias e culturais cumpriram, na primeira metade do século XX, um importante papel como espaço de intercâmbio intelectual. Assim como os jornais, as revistas, por seu caráter de "obra em movimento", de escrita mais efêmera que dos livros, serviram de "espaço de experimentação", onde as ideias dos autores se ofereciam à discussão e se testavam permitindo a publicação de trabalhos ainda em curso.

Assim como os demais espaços de trocas intelectuais, as revistas serviam de ponto de encontro de itinerários individuais sob um credo comum. Uma revista - escrita plural e coletiva - veicula, ao ser publicada, uma proposta singular e reivindica, em oposição a outras, uma nova cultura, uma nova estética ou uma nova orientação científica que ela significava ou não sob a forma de um manifesto ou de um artigo fundador. Ao tornar-se pública, a revista tomava a aparência de um projeto consolidado, unido, minimizando, ou fazendo desaparecer, todo o processo que levara à sua organização e que, nos "bastidores", se caracteriza por disputas intelectuais e políticas.

Segundo Venâncio, essa investigação, no entanto, é dificultada pela escassez de fontes que se referem aos processos de criação e publicação de tais periódicos. Para desenvolver esse tipo de abordagem, podem ser considerados alguns tipos de fontes tais como os diários, as memórias de literatos e editores e as correspondências. Sendo todas elas fragmentárias e dispersas, tanto mais por serem características, principalmente, de arquivos privados pessoais, de difícil localização e, frequentemente, não organizados e/ou fechados para pesquisadores.

Frente a tais argumentos, a autora demonstra que ainda que seja uma fonte difícil de se trabalhar, em função de seu caráter de documento de complexo tratamento analítico, dentre as fontes citadas as correspondências possuem um traço singular: elas portam os diálogos, as falas de editores e colaboradores, de solicitantes e solicitados, e 
são, por este motivo, fontes privilegiadas para observar a intensa negociação que se estabelece em torno de um projeto editorial (VENÂNCIO, 2007, p. 9-11).

O ensaio Monteiro Lobato e Câmara Cascudo: correspondência, história e teoria literárias de Marisa Lajolo (2013), indiretamente, referenda o acima proposto. $\mathrm{Na}$ leitura das cartas de Monteiro Lobato para Cascudo, Lajolo argumentou que tinha uma expectativa de encontrar nos documentos um diálogo estabelecido em torno da cultura popular, mas ao invés disso, a correspondência se colocaria como uma fonte promissora para o conhecimento mais acurado da engrenagem literária concebida e posta em prática por Monteiro Lobato que, em 1920, além de escritor de sucesso, era também o respeitado editor da Revista do Brasil e provavelmente o responsável pela linha editorial das publicações que saiam com a chancela da revista.

Das dezesseis cartas que Monteiro Lobato enviou a Câmara Cascudo, Lajolo se concentrou nas sete redigidas entre 1920 e 1922, lendo e analisando-as com o objetivo de delas extrair dados relativos ao sistema literário vigente. As perguntas feitas giraram em torno dos seguintes tópicos: quais obras e autores elas mencionam? Quais bases técnicas da produção literária (redação de originais, condições de edição e de circulação) elas desvelam? Que geografia literária elas delineiam? Para que expectativas de público elas apontam?

$\mathrm{O}$ argumento central de Lajolo propõe que muito mais do que interlocutor para as preocupações folclóricas do Monteiro Lobato desta época, Cascudo é visto pelo editor paulista como um virtual divulgador da Revista do Brasil e agenciador de assinaturas para ela; como eventual vendedor de livros editados pelo selo paulista e até como procurador de Monteiro Lobato para a adoção de seus livros pela rede escolar do Rio Grande do Norte, como se pode observar nas passagens a seguir (LAJOLO, 2013, p. $16 ; 20-21)^{52}$ :

Pegue a laço ahi quatro assignantes e mande os cabras: fica assim com a tua assinatura de graça. É o melhor systema - para a casa e o freguez.

A revista mudou de 'perfeito'. É o Paulo Prado. Eu como sempre, simples enfeite, e espécie de poder que me deram, de interventor...em favor dos amigos velhos. Porisso, com ella.

Estamos aqui sem novidade, que está dando um tostão: venda de livros a prestação.

\footnotetext{
52 Aqui, utilizaremos as transcrições elaboradas por Emerson Tin (2007a), que em sua tese de doutorado as disponibilizou para consulta (Cf. TIN, 2007a).
} 
Vou mandar mandar o chefe dessa secção escrever a você, pedindo qualquer coisa. Poderás arranjar-me a coisa ahi (...) (ML, s/d, apud, TIN, 2007a, p. 525).

Não sei se lhe mandei meus últimos livros $\mathrm{p}^{\mathrm{a}}$. creanças. Na duvida, vão de novo. E agora um negócio: pode informar-me do processo para apresentação de livros didacticos que pretendem a adopção na escola desse estado? A quem se requer? Quer o amigo requerer por mim, como procurador? Ou então diga-me a quem se requer, em que sede, e o mais que é mister fazer. Esses livros foram adoptados pelo est. de $\mathrm{S}$. Paulo e estão em via de ser por Minas, Rio, Parahyba e outros (ML, s/d, Id. Ibidem, p. 524).

Nestas poucas cartas enviadas por Monteiro Lobato a Câmara Cascudo, pode-se perceber algo de semelhante com as de Mário de Andrade. A primeira das dezesseis cartas demonstra que o diálogo também foi iniciado devido ao envio de recorte com artigo que Cascudo redigiu sobre Lobato e publicado na coluna "Bric-á-brac", de sua autoria e que compunha as secções do jornal A Imprensa. Nesta carta de 1920, o editor paulista acusa o recebimento e o entusiasmo pela iniciativa do jovem escritor:

Recebi um n'. d 'A Imprensa' onde vem vem um artigo seu a meu respeito.

Desvanecido pelos elogiosos conceitos com que mimoseou minha insignificante personalidade, cumpre-me agradecer-lh'os affectuosamente. Infelizmente faltam-me forças e dons para ser o bandeirante que diz. Poderia, no máximo, ser um porta-bandeira, um soldado, como suspira o Fernão Dias que o momento social pede. Virá ele? (ML, 8-VI-1920, apud, TIN, 2007a, p. 519)

Sem sombra de dúvidas, podemos afirmar que a iniciativa de Cascudo teve como intenção estabelecer um vínculo de aproximação com Lobato, com o intento de se fazer conhecido nos grandes centros intelectuais e editoriais do país à época. Pois escrever para a Revista do Brasil era, naquele momento histórico, o sonho de muitos intelectuais, visto que este periódico havia se tornado uma das mais importantes publicações do período em questão. Lobato, também pretendia realizar um panorama completo do Brasil através da colaboração de vários intelectuais e escritores, promovendo seu sucesso editorial, fazendo com que a revista contasse com a participação de autores de matizes diversos, desde os grandes nomes da chamada "geração de 1870", passando 
pelos intelectuais católicos, pelos pensadores autoritários e pelos modernistas (VENÂNCIO, 2007, p. 20).

Lajolo nos chama atenção para a carta de vinte e seis de setembro de 1920, nela se delineia a relação editor/escritor registrando e revelando que continua em jogo um sistema de trocas, explicitando-se agora recompensas simbólicas eventualmente de valor maior do que qualquer valor econômico. $\mathrm{O}$ todo poderoso editor paulista acena com a publicação de colaboração de Câmara Cascudo nas prestigiosas páginas da Revista do Brasil, incentivando o envio de material (LAJOLO, 2013, p. 23):

Recebi sua de 14, com prazer duplo, pois anuncia que vae mandar suas impressões do sertão para a revista. Muito bem. É isso mesmo que ela quer: impressões pessoaes, directas, sobre as nossas coisas e não-variações sobre um thema em si bemol - regra da nossa produção literária, e mal tremendo. Venha, pois, de lá isso, e bem recheiado de observações, 'causos', anecdotas, etc e bem rescendente ao sabor da terra. O mal do Brasil é conhecermo-nos mal, e peior ainda ás nossas cousas (ML, 20-IX-1920, apud, TIN, 2007a, p. 520).

Como vemos, a proposta de colaboração de Cascudo é pretexto para Lobato expressar suas ideias relativas à arte (nacionalismo, crítica à literatura contemporânea, compromisso com a linguagem desativada). Na transcrição acima, essas relações ganham relevo, sobretudo por se manifestarem às vésperas da cosmopolita Semana de Arte Moderna paulistana da qual como se sabe, Monteiro Lobato não participou. Mas com cujos ideais comunga em alguma medida, chegando mesmo a antecipá-los (LAJOLO, 2013, p. 30).

Em outra carta, de vinte e sete de junho de 1921, Lobato discute a aparência e legibilidade dos originais, atitude bastante compreensível para quem - como o editor que então ele era - recebia grande quantidade de originais, ficando pois à mercê de caligrafias menos ou mais legíveis: "É preferível que os originais venham datilografados - por mil e uma razões. Devia ser proibido pelo código escrever-se a mão obra destinada ao prelo". Noutra carta já citada anteriormente, Lobato também estabelece críticas do mesmo teor, pensando na possibilidade de impressão do Histórias que o tempo leva ${ }^{53}$ : "Olhe: se entregaste ao prelo as tuas Histórias, não te esqueças a

\footnotetext{
${ }^{53}$ Em carta entre os anos de 1922 e 1923, Lobato questiona sobre a estrutura do livro e aconselha o jovem escritor: (...) "O livro...mas como é teu livro? De que trata? Não tenha pressa em fazel-o nem force a
} 
revista. És arquirrelaxado. É preciso que te reabilites" 54 (LAJOLO, 2013, p. 22; 24-25; 29; TIN, 2007a, p. 522; 525).

Outra abordagem também comum à correspondência entre Mário e Cascudo é o insistente convite que Cascudo fará a Lobato para vir conhecer as "coisas do Norte", só que, diferente de Mário, Lobato, não realizará a viagem. Na primeira delas, em resposta a comentário feito por Cascudo sobre algumas de suas incursões no interior do Rio Grande do Norte: "Fiquei a lhe invejar a excursão pelo interior desse Estado: tenho uma vontade imensa de conhecer todo o interior do paiz mas ele é tão grande e tudo nelle tão diffícil que desanima" (ML, 26-IX-1920, Apud, TIN, 2007a, p. 520). Novamente em carta de 30 de março de 1921, Cascudo reitera o convite, Lobato se mostra entusiasmado, mas pretere a iniciativa frente às obrigações com os negócios, prometendo a qualquer instante, verificar se o amigo "Câmara é Cascudo mesmo ou historia":

A minha ida...Socegue. Dia virá. Primeiro preciso consolidar esta casinha editora deixando-a funcionar sobre mancaes de bolinhas SKF. Ahi, então, poderei dar minhas fugidas. Por ora não penso nisso. E quando chegar a ocasião não deixarei de ir ver de perto si o $\mathrm{a}^{\circ}$ Camara é Cascudo mesmo ou historia (ML, 30-III-1921, Id. Ibidem, p. 521).

Cada vez, esse projeto ficava para ser posto em prática a posteriori, talvez quando Lobato se aposentasse, porque naquela ocasião se encontrara totalmente absorvido com seu trabalho, tentando ser rico, esperando se aposentar em no máximo três anos, quando viria o tempo de calma e vadiação, como podemos ver na carta de cinco de maio de 1922:

Estou vendo que a minha viajem ao norte só poderá ser $\mathrm{p}^{\mathrm{a}}$. Quando eu me aposentar, isto é, ficar bem rico. Porque o trabalho apaixona e absorve de tal maneira que não admite brecha. Mas tempo virá, de calma vadiação... E irei conhecer esse encantado canto do mundo em companhia do querido amigo. Se as coisas continuarem como vão

factura. Os bons livros saem naturalmente, como creanças que vem a termo. Seja homem de um livro só mas execellente, imorredoiro" (ML, S/d, apud, TIN, 2007a, p. 524).

${ }^{54}$ Sobre este aspecto, Cascudo confessa a Mário: "Hoje recebi uma carta do Lobato estranhando a gramática do Histórias que o tempo leva... (o meu filhinho histórico). Veja lá até onde chega o humorismo do Lobato..." (CC, 25-VIII-1924, apud, CASCUDO, 2010a, p. 34). 
creio que em três anos já posso me aposentar (ML, 5-V-1922, Id. Ibidem, p. 523).

Em outra carta não datada, mas possivelmente escrita entre 1922 e 1923, Lobato apresenta as razões que o impossibilitam de viajar, embora muito quisesse, não poderia ir ao norte, abandonando o projeto de viajar e realizar pesquisas para escrever uma obra literária pautada nestas experiências, o projeto, havia naufragado devido à condição de saúde de sua esposa, não o deixando arredar o pé de casa:

Querer não é poder. Quero e não posso ir ao norte - porque sou casado, a mulher é doente de nervos e nunca posso arredar pé de casa. A obra literária que eu tinha vista e que dependia de sahir, viajar, conhecer o paiz de norte a sul, essa naufragou. Sou um literato que se aposentou-se logo em seguida à nomeação, e isso porque há no mundo nervos de mulher. Enfim...uma encrenca que matou no ovo uma coisa grande que eu tinha cá dentro. E deveras lamento isso, às vezes. Como agora: que magnífico conhecer essa zona ao lado de um guia tão inteligente e amigo como V.? Mas, o homem põe e os nervos femininos dispõe (ML, s/d, Id. Ibidem, p. 523).

Nesses termos, tão pessoais, e mesmo considerando impossível, Lobato não perdia as esperanças, principalmente em virtude da descrição do principado do Tirol ${ }^{55}$, realizada por Cascudo, acreditando que ainda veria de perto tal residência, não tinha perdido as esperanças:

Porque foi falar na casa em que mora, 'tranquila, rodeada de arvores, perto do mar'? Encheu-me de saudade e inveja, porque eu moro no centro desta infernal que cresce e trepida dia e noite e me deixa os nervos em miserável estado. Que felicidade morar fora do inferno! Que paz deve reinar ahi!

\footnotetext{
${ }^{55}$ No livro de memórias $O$ Tempo e eu (1968), Cascudo narra como foi adquirida e de como era sua organização e disposição: "Em fins de 1913 meu Pai comprou ao arquitecto Herculano Ramos, por 20.000 \$ a 'Vila Amélia' no Tirol, região de chácaras e quintais. A propriedade abrangia três quartas partes do quarteirão entre as avenidas Campos Sales e Rodrigues Alves, Apodi ao fundo e à frente a Jundiaí, onde tinha o $\mathrm{n}^{\circ}$ 93. (...) Aqui outrora retumbaram hinos! Fundou-se o Principado do Tirol (...) Dessa Vila Cascudo planejou-se muita festa vitoriosa e não mais repetida, bailes elegantes e mesureiros, Tea-Tango, Five-ó-clock, (...) planos de renovação literária, apoio à 'Semana de Arte Moderna', leitura de originais de poemas de poetas dos Estados vizinhos, euforia, magnificência". A casa foi perdida devido ao endividamento do Coronel Cascudo com uma hipoteca de 30.000 \$ nos idos de 1937 (CASCUDO, 1968, p. 62-65).
} 
Mas deixa estar que se se me azar ocasião irei ver isso de perto. Não perdi de todo a esperança (ML, s/d, Id. Ibidem, p. 524).

O tempo havia passado, e Cascudo envia nos idos de setembro de 1944 nova carta, questionando se o velho amigo Lobato ainda resguardara na memória a lembrança do amigo de outrora. Em retribuição, Lobato, não só escreve, mas envia novo retrato e promete que ao final da segunda grande guerra e quando houvesse maior facilidade de circulação, iria fazer um sossegado passeio pelo norte; para rever seus verdes mares e recordar com o amigo o tempo e os sonhos da mocidade:

Se me lembro desse Cascudo? Oh, sim, porque não entram muitos cascudos na vida da gente e esse é um grande cascudo. Inda ha dias, numa redução do meu arquivo, encontrei uma batelada de cartas cascudeanas e reli varias, com muita saudade daquele tempo. E agora o meu velho Cascudo faz-se lembrado...

Vinte anos faz que te mandei meu retrato sem bigodes? Pois, mando agora um de bigodinho. Os anos vem vindo e vão amarrotando a cara da gente, como os pontapés e trancos da rua fazem ás latas velhas. Mas espero que essa vidinha mais calma aí não te haja trazido um amarrotamento igual ao meu. Alem de que os cascudos devem defender-se melhor.

(...)

Quando acabar esta maldita e interminável guerra e vivermos de novo facilidades de circulação, quero fazer um sossegado passeio pelo Norte, com paradas compridas aqui e ali, e então irei ver se és de fato cascudo - ou és cascudo como eu sou lobo. E eu reverei esses mares daí realmente verdes - 'os verdes mares bravios da minha terra' - e os mais bonitos que conheço (...). (ML, IX-1944, apud, TIN, 2007a, p. 528).

Foi através desta correspondência, e apesar de tão diferentes, que Cascudo e Lobato mantiveram uma amizade que durou mais de vinte anos, só sendo interrompida com a morte do escritor paulista. Como mencionamos anteriormente, por intermédio do estudo de Veríssimo de Melo, e segundo o depoimento de Cascudo por ele recolhido, houve o recebimento de 200 cartas, embora só as 16 que em parte foram aqui abordadas sejam do conhecimento de alguns pesquisadores. O próprio Lobato, nesta última mensagem transcrita, menciona: (...) "Inda ha dias, numa redução do meu arquivo, 
encontrei uma batelada de cartas cascudeanas e reli varias, com muita saudade daquele tempo" (...). O que terá acontecido com estas cartas? Será que tenham vindo a cabo no momento da respectiva redução do arquivo lobatiano? Não sabemos ao certo. Mas como demonstrou Lajolo (2013) e Tin (2007b), essa documentação não foi encontrada. Numa carta, datada de 29 de março de 1939, podemos encontrar por fim, o balanço dessa amizade (TIN, 2007b, p. 268):

\footnotetext{
Cascudo, a vida nos junta em dado momento e depois nos separa. As trajetórias nem sempre são paralelas, mas mesmo desparalelados, nunca me esqueço dos velhos amigos do bom tempo. Normalmente, quando além de amigo, se trata de um Cascudo, aliás, só no nome, porque não pode haver ninguém menos Cascudo que você. Na alma, na arte e na amizade (ML, 29-III-1939, apud, TIN, 2007a, p. 527).
}

Tomando as palavras de Lobato, podemos afirmar que embora eles estivessem “desparalelados", nunca deixaram morrer essa amizade que os ligava, por mais diversas, que pudessem ter sido suas trajetórias de vida e no meio intelectual.

\subsubsection{Rocha Pombo (1920 -1928)}

Trataremos agora da correspondência do historiador Rocha Pombo enviada a Luís da Câmara Cascudo. Foram catalogados 12 documentos no Instituto Ludovicus Câmara Cascudo, enviados no decorrer de 1920 a 1928. Neles, são tratados temas da história do Rio Grande do Norte e da cidade do Natal, e outros mais gerais da história do Brasil; com ênfase no processo de criação de sua primeira publicação de caráter histórico, Histórias que o tempo leva... (1991a), o livro fora dedicado a Rocha Pombo e prefaciado pelo respectivo correspondente. É importante lembrar que esta obra foi impressa e distribuída pela editora de Lobato, fazendo com que o nome do jovem Cascudo viesse a partir da publicação a ganhar projeção nacional, pois seus primeiros livros Alma Patrícia (1998a) e Joio (1991b), por terem sido produzidos graficamente no editorial do jornal $a^{\prime}$ Imprensa, não tiveram a mesma amplitude e divulgação, embora aclamados pela crítica, como é possível perceber nos anexos do segundo livro.

Nos primeiros anos de sua atividade literária, Cascudo dedicou-se, sobretudo, ao duplo trabalho de crítico literário e de historiador. A reiterada associação de sua identidade intelectual às artes da história desafia seus intérpretes como um enigma, 
logo, entender os significados possíveis do apelativo de historiador a ele atribuído pode fornecer alguns indícios significativos para, por um lado, verificar qual a particular conjugação entre a história e o projeto intelectual estabelecido em sua obra e, por outro, discutir o lugar, plural e controvertido, do folclorista potiguar na historiografia brasileira e na história da cultura (NEVES, 2002, p. 67).

O livro Histórias que o tempo leva... (1991a), por ser uma das primeiras obras saídas da pena de Câmara Cascudo, paga o tributo à juventude de seu autor e constitui uma obra fortemente marcada pelo pensamento social conservador de sua época, além de esboçar alguns padrões que sua extensa obra de historiador retomará, ainda que de diferentes formas e outras abordagens.

De acordo com Margarida de Souza Neves (2013), o primeiro destes padrões diz respeito aos temas tratados neste livro de estreia nos territórios da história. Por toda a vida, o Cascudo historiador terá como uma de suas preferências temáticas os assuntos relativos ao Rio Grande do Norte e às biografias exemplares ${ }^{56}$. E estes, são temas que dominam suas Histórias... de 1924. O segundo se refere ao gênero da escrita, próximo da crônica e do conto, que valoriza a descrição e os detalhes e darão ao leitor a ilusão de que a narrativa é feita por uma testemunha ocular dos fatos ${ }^{57}$. Um terceiro traço marcante de sua historiografia se delineia neste livro de juventude, pois nele o autor deixa perceber sua visão hierárquica da sociedade e faz uso de conceitos tais como o de raça superior, próprio de seu pensamento conservador, embora o argumento racial perca espaço em sua obra madura, seguindo o debate dominante sobre a sociedade brasileira ao menos desde os modernistas e consolidado por Gilberto Freyre em Casa Grande \& Senzala. Um quarto padrão de sua historiografia, surpreendente em seus textos de história da década de 1920, reside no fato de abrir espaço na história que escreve para o testemunho oral, as lendas e tradições populares e atribuir-lhes um valor heurístico, tendência já anunciada na respectiva obra. Por fim, a autora argumentou que o traço mais sutil e sempre presente em sua obra diz respeito a um duplo movimento

\footnotetext{
${ }^{56}$ Para tanto, confira (NEVES, 2013, p. 125; nota 4).

${ }^{57}$ Em carta não datada, escrita por volta do período da revolução de 1924 em São Paulo, possivelmente posterior ao mês de julho do respectivo ano, vemos Lobato fazer aquela consideração sobre a referida obra: “A revolução me pegou fóra de S. Paulo e só me permittiu que entrasse ha 3 dias. Aproveitei a paralização de tudo $\mathrm{p}^{\mathrm{a}}$ ler o teu livro, que é dos mais interessantes que conheço no genero. Como v. é $\mathrm{m}^{\text {to }}$. pessoal, os episódios, apesar de serem vagabundissimos como no geral todas as partes de uma insipita historia, ganham $\mathrm{m}^{\text {to }}$. Relevo e prendem singular ${ }^{\text {te. }} \mathrm{A}$ atenção. Tanto é certo que o que vale não é o facto em si e sim o estylo do contador. Gostei muito do retrato do Barata, do Koster e das reminiscencias. Não ha dúvida: és um escritor. E se te apurares na lingua com o tempo, ficarás um grande escritor". (ML, S/d, apud, TIN, 2007a, p. 525).
} 
diante do tempo histórico e que se traduz tanto por algo muito próximo à perplexidade diante da inexorável voracidade do tempo que passa quanto pelo desejo de deter o tempo fugaz e transformá-lo, por obra e graça das letras, num presente contínuo, efeito conseguido pela busca de informações adormecidas em documentos e na memória dos que testemunham fatos acontecidos, assim como pela função de mestra de vida ${ }^{58}$ para o presente que a história pretérita deveria, em sua perspectiva, assumir (NEVES, 2013, p. 130-131).

Nas cartas enviadas por Rocha Pombo a Luís da Câmara Cascudo, percebe-se que a primeira delas tem uma característica comum com a correspondência de Mário de Andrade e a de Monteiro Lobato: também se inicia com o agradecimento ao jovem intelectual por ter escrito em quatro de abril de 1920 o artigo "A herança de Ramsés", onde Cascudo trata sobre aspectos da vida e obra de Rocha Pombo. O autor tomou conhecimento do texto por intermédio de um amigo em comum, Jayme da Camara, e nela demonstra sua recepção:

Devo a um seu muito conhecido, o meu já estimadíssimo amigo Jayme (sic.) da Camara, a fortuna de possuir um exemplar da

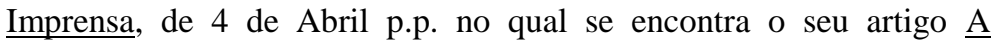
Herança de Ramsés.

Ainda, não li, entre as coisas amáveis com que as veses me honram alguns confrades e amigos, nada que commovesse tanto como este pouco que o $\mathrm{Sr}$. Dis a meu respeito. As suas grandes palavras me tocaram muito no fundo o meu coração, e têm de ficar entre os (sic.) mais valiosos do espolio sagrado que reservo para os meus filhos.

Nada valeria tentar agradecer-lhe por estas linhas: basta-me que saiba como sinto o que me vem da sua grande alma (RP, 10-V-1920).

O entusiasmo causado pelo conhecimento do texto faz com que brote a partir de então uma forte amizade. Só que uma segunda carta virá em seis de fevereiro de 1921, como réplica a uma carta enviada por Cascudo em meados de janeiro do mesmo ano, conforme aponta o documento. Nesta, são tratados aspectos relacionados a dúvida de Cascudo quanto a um evento em torno da historiografia do Rio Grande do Norte - a ação de André de Albuquerque durante a revolução de 1817. Rocha Pombo aponta algumas possibilidades, que pelo que se percebe, já eram de conhecimento do jovem

\footnotetext{
${ }^{58}$ De acordo com a autora, os matizes teóricos de Cascudo englobam a história magistra-vitae de Cicero, a hagiografia medieval e os princípios positivistas de Ranke (NEVES, 2002, p. 75).
} 
historiador; lamentando já ter enviado seu História do Rio Grande do Norte ao prelo, pois poderia mandar uma cópia do capítulo em que tratava do assunto, sendo isto "o máximo que lhe poderia oferecer":

Cá recebi com muito praser a sua carta de 21 do p.p. Vejo que já está bom e forte. Aconteceu-me a mim o mesmo que lhe sucedeu ao ter de avir-me com a papelada relativa ao caso de André de Albuquerque; e ainda hoje estou em dúvida quanto a certos incidentes. Penso no entanto que na Revista do Instituto dahi ha de mostrar alguma coisa que o oriente. Em ultimo caso, si for de todo impossível apurar certas minucias de datas, o mais rasoavel é ficar as fontes, é claro que com o cuidado de evitar anachronismos e contradições. Foi isto mesmo que eu fis no capitulo da Historia do Rio Grande do Norte relativo a revolução de 1817 ahi. Lamento que já estejam os meus originaes com o editor; pois si ainda estivessem commigo, mandar-lhe-ia uma copia desse capitulo - que é o máximo que lhe poderia oferecer.

Pelo que vejo na sua carta o amigo já está bem preparado de elementos para o que vai faser. Além dos documentos que menciona, não conheço mais nenhum. (...) (RP, 6-II-1921)

Conforme apontou Margarida de Souza Neves (2013), boa parte dos contos históricos sobre o século XIX se refere ao heroísmo presente nos norte-rio-grandenses que participaram do movimento de 1817 , de matizes republicanos, o que não deixa de ser surpreendente tento em vista o fato de termos nos acostumado a ler Cascudo como o historiador monarquista que se tornou na maturidade ${ }^{59}$. No entanto, na virtual totalidade desses escritos, os agentes sociais se apresentam estratificados em dois grandes grupos: aquele formado pelos que - independentemente de seu lugar social são nobres, altivos e heroicos e os traidores, velhacos e covardes, os que Cascudo não hesita em situar como representantes de raças inferiores (NEVES, 2013, p. 136-137), tal qual podemos constatar a seguir:

\footnotetext{
N'aquelle meio brilhante de officiaes, eclesiásticos, vereadores, comerciantes, politicos e ricos, Ignacio Manoel, o soldado humilde da fortaleza dos Reis Magos e Ritinha Coelho, a mulher do povo, desconhecida e pobre, foram os unicos que tiveram para André d'Albuquerque, nos instantes derradeiros e na hora da vergonha e do
}

\footnotetext{
${ }^{59}$ Sobre este aspecto, ater-nos-emos com maior dedicação na secção seguinte.
} 
insulto, a suprema caridade das ultimas esmolas (CASCUDO, 1991a, p. 121).

Ainda no ano de 1921, só que em vinte e nove de setembro, vemos os elogios e agradecimentos de Rocha Pombo pelo envio da obra Alma Patrícia (1998a) ${ }^{60}$; o historiador demonstrou admiração e lamentou não ter o conhecido durante a elaboração de seu livro, História do Rio Grande do Norte, teria sido tomado como fonte de pesquisa. Outro assunto tratado na respectiva carta é a surpresa em saber que seu amigo Henrique Castriciano também o era de Cascudo, principalmente, por ser Castriciano poeta; condição que até aquele momento era desconhecida, mesmo que na carta, Rocha Pombo demonstre ter convivido com "o príncipe dos poetas", só tomara conhecimento dos versos do amigo por intermédio do livro de estreia do jovem Cascudo:

\begin{abstract}
Aqui estou para agradecer-lhe a sua Alma patricia. Bello! Cultive o gênero - que ha ir longe. Não lhe perdôo-o grande mal que me fez...deixando de fazer-me um bem enorme: porque é que só agora é que publicou esse livro? Se me tivesse vindo antes, tel-o-ia com certeza aproveitado na integra para o meu trabalho, que está no prelo, sobre o nosso Rio Grande do Norte.

Mas um capitulo da sua Alma prendeu-me especialmente a atenção por uma particularidade muito pessoal: é o relativo a $\mathrm{H}$. Castriciano. $\mathrm{O}$ que me diz ahi é novo, e alguma coisa do que me dá é admiravel; como por exemplo, este maravilhoso soneto Monologo de um bisturi. É estupendo! Mas, meu Jesus! - como as almas se desconhecem quando separadas pela distancia! É incrível! (RP, 29-IX-1921).
\end{abstract}

Na única carta escrita em 1922, vemos Rocha Pombo, falar da felicidade em ver que o jovem escritor "vá orientando o seu bello espirito no sentido das nossas coisas históricas", desejando os parabéns pelo livro concluído e pronto para a publicação. Tratava-se de Histórias que o tempo leva... (1991a) que só veio a ser publicado dois anos depois. Nesta carta, Rocha Pombo confessa com alegria estar "prompto, de alma bem aberta, a prefaciar o seu livro", pedindo o envio de alguns capítulos que o habilitassem no intento da apresentação do Cascudo historiador:

\footnotetext{
${ }^{60}$ Em outra carta, Rocha Pombo ainda fará uma breve menção a Joio (1924b) e Histórias que o tempo leva ... (1924a), questionando-o sobre quando os livros seriam publicados; aspecto que abre espaço para levantarmos a hipótese de que Cascudo tratou com o mesmo correspondente de todos os seus projetos bibliográficos da primeira mocidade: "Meu caro Cascudinho: e quando é que vem o Joio? E quando aquelles belos contos historicos?" (RP, 15-I-1924).
} 
Vou logo ao ponto de que trata na mesma. Folgo bastante que vá orientando o seu bello espirito no sentido das nossas coisas históricas; e dou-lhe desde já os meus parabens pelo livro que concluiu e vai publicar. Acho de uma graça infinita o que me dis quanto á necessidade de quem o apresente. Os legitimos talentos não precisam disso: antes de diser o nome, dizem logo o que são pelo que fasem. Já, porem, que o jovem amigo, na sua modéstia, não entende assim, devo, por minha vez, extranhar-lhe a consulta que me faz. Só se consulta quando se tem duvida: pois então dar-se-á que o Sr. Chegou a duvidar que lhe aceitasse muito desvanecido, a honra que me oferece?

Saiba, pois, que estou prompto, de alma bem aberta, a prefaciar o seu livro. É necessario para isso que me remeta ao menos alguns capitulos que me habilitem a diser da obra. Entre os titulos de capitulos que indicou de certo que não arriscaria a destacar nenhum; deixo isso ao seu cuidado. Não esquecerá de enviar-me, com a copia que me promette, algumas indispensáveis notas bio-bibliographicas. Fique certo de que farei o que está no meu coração e no meu espirito de justiça (RP, 22-IX-1922).

No prefácio, Rocha Pombo, além de arriscar um prognóstico, ao afirmar "sinto, desde já, que Luis da Camara Cascudo irá direto a dar consigo nas amplitudes da história" (ROCHA POMBO, 1922, p. IX, apud, CASCUDO, 1991a), o situa como um seguidor de Viriato Correia, por utilizar uma narrativa próxima à dos contos e por escrever uma história que caia no gosto do grande público; gênero sobre o qual faz uma observação interessante: "Digamos logo que esse modo de divulgar e fazer sentida a nossa história não há dúvida que é o mais simples e popular, e, portanto, o mais eficiente" (Id. Ibidem, p. IX). É sutil a distinção feita por Rocha Pombo entre o mais simples e popular modo de divulgar e fazer sentida a nossa história, próprio, em sua avaliação, do gênero histórico praticado pelo livro de estreia de Cascudo como historiador, e as amplitudes da história, destino futuro que enxerga para o jovem escritor que prefacia em 1922. E parece acertada a aproximação que faz entre a escrita da história deste livro e as liberdades do conto, que se afasta do rígido protocolo narrativo de uma história científica que começa a se consolidar ainda mais no panorama historiográfico brasileiro da época, em prol do objetivo de fazer sentida a nossa história (NEVES, 2013, p. 133-134). 
Em cartas escritas entre vinte e sete de dezembro de 1923 e quinze de janeiro de 1924, vemos um ato de gratidão realizado por Cascudo a seu velho amigo Rocha Pombo. Utilizando-se de sua influência no meio político da cidade do Natal, para premiá-lo pelos préstimos realizados para o estado do Rio Grande do Norte. Cascudo contou para tanto com a ajuda de seu Pai, o coronel Cascudo, Juvenal Lamartine e José Augusto. No mês seguinte, Rocha Pombo recebeu no Banco Germânico a quantia de dois contos de réis:

Recebi hontem a sua affectuosa carta de 16 corente, e aproveito a $1^{\text {a }}$ mala para escrever-lhe. Como dizer por escrito as efusões todas do meu coração? Cada vez mais me convenço de que v. é um caso essepcional de intelligencia e amor. (...)

Agora, respondo á sua missiva. Não tenho instruções a dar-lhe: v. é que me dirá o que devo faser: si lhe enviarei procuração, ou si v. fará que a entrega do premio seja feita aqui por intermédio de um banco. Penso que isto será mais facil, como v. mesmo pensa. Si fôr necessária a procuração, espero que me avise logo. Fico esperando (RP, 27-XII1923).

Acabo de telegraphar-lhe avisando que recebi hoje no Banco Germanico os dois contos que V. ahi arranjou como premio pela nossa Historia. (...) quem me dera essa fortuna para de viva voz agradecer ao meu jovem grande amigo, e a todos quanto concorreram para este exercisso de manificencia que o Rio Grande tem commigo!

Si isso, no entanto só pode estar na minha esperança nos impulsos do meu coração: e que é pedir-lhe que por mim faça sentir ao seu digno Pai, ao dr. Juvenal Lamartine e aos demais que V. fez entrar nesta 'obra boa' - quanto lhes sou a todos grato. Não tomo a liberdade de escrever a cada um delles porque V. nada disse ainda a respeito e não quero metter-me a taralhão. Ao Dr. José augusto, no entanto escrevo agora, para aproveitar o ensejo de felicital-o (RP, 15-I-1924).

Na carta de vinte e oito de outubro de 1924, vemos Rocha Pombo, um pouco hesitante em comentar um dos trabalhos de pesquisa histórica de Cascudo, trata-se do López do Paraguai, parecia não compreender o interesse do jovem escritor pelo personagem e desejava que o amigo "fosse mais formal e categórico quanto a esta para sempre detestada figura":

É assim que v. quer: assim vá. Cá está o seu López do $\underline{\text { Paraguai. }}$ 
Muito interessante. Conciso e forte.

Desejaria que v. fosse mais formal e categórico quanto a esta para sempre detestanda figura.

Ainda assim, dando prós e contras, é muito interessante. Dou-lhe os meus parabens e os meus aplausos. (...) (RP, 28-X-1924).

Através dos comentários realizados por Rocha Pombo, tomamos conhecimento de um dos primeiros eventos da História do Brasil a despertar o interesse do historiador: a Guerra do Paraguai. No livro López do Paraguai, vemos reconstituída a trajetórias de figuras contrapostas: Francisco Solano López e o Conde d’Eu. Na montagem dessas biografias, foram identificadas duas grandes contribuições para o império "sonhado": uma dada tradição de monarquia pacifista de tradição europeia e o exemplo de “príncipes perfeitos" para a nação no passado e no presente, reconhecidos nos monarcas da casa de Bragança e em membros da quarta casa d'Orleans, particularmente na pessoa do príncipe-consorte Gastão de Orleans e de seus descendentes, os príncipes Pedro, Luís e Antonio d'Orleans e Bragança. A imagem do Estado bom, forte, ordeiro, um leal e desinteressado "S. Christovão pacificador de povos e estrangulador de monstros" espelha-se na intervenção do império na tragédia perpetrada por Solano López, onde se defrontaram a civilização - representada pelo Brasil conduzido por Pedro II, seu povo, seus generais e soldados - e a barbárie, cristalizada nos atos do ditador paraguaio (MARSON, 2013, p. 83).

Em vinte de setembro de 1925, vemos por intermédio de carta enviada por Rocha Pombo que Cascudo pedia ao amigo para intermediar a aquisição de algumas obras para seus estudos. Como podemos observar no capítulo anterior, esta condição também foi posta em prática com outros correspondentes. Nesta carta, Rocha Pombo comenta não só a respeito da busca das obras pedidas, como do feito de estabelecer o contato entre Cascudo e Eduardo Lemos, gerente da casa Garnier no Rio de Janeiro, facilitando assim o acesso a publicações importantes para os seus estudos:

Logo que a recebi [a carta], cuidei de dar cumprimento ás suas ordens, com muito praser. Para isso pareceu-me mais (sic.) entender-me com o meu amigo Eduardo Lemos que está na gerencia da casa Garnier, e é muito competente em bibliographia. E não me arrependi. Ao cabo de algumas visitas com que o atropelei, communicou-me elle hontem que já lhe remetteu os melhores autores á mão faltando apenas a obra sobre (sic.), a qual está procurando e assim que encontrar mandará. 
Também autorizou-me a diser-lhe que, si entre os livros que vão algum houver que, lhe não aproveite, ou não lhe agrade, poderá devolvel-o á propria casa; e que, portanto, só depois é que ha de dar a conta para o pagamento. Parece que assim fica bem, não é? (RP, 20IX-1925).

Outra carta de 1925 nos mostra o historiador paranaense a apresentar algumas sugestões de leituras para o jovem escritor potiguar, trata-se de obras que abordam temáticas sobre História Geral e História da América, entre as sugestões para o primeiro tema vemos a proposição de autores positivistas tais como Seignobos; sobre o segundo, confessa que sua obra História da América consistia-se na melhor opção para uma primeira orientação:

Quanto aos compendios de H. Geral, posso indicar-lhe os melhores que conheço. O mais completo e excellente é a obra de J. Crozals -

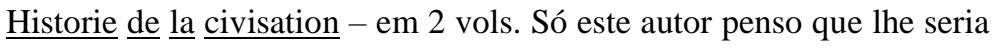
bastante. Vem depois: Seignobos, também em 2 vols. Estes se encontram em todas as livrarias. Ha mais: Jalliffier et Vasta 4 vols: Albert Malet, Max Mitard, V. Duruy, (sic.) Driame, e outros. Mas, repito que Crozals, acima de todos.

Quanto á nossa America, só compêndios didacticos de historia nacional, e conta pouco. A proposito, acaba de publicar-se a $2^{\mathrm{a}}$ edição da minha Historia da America. Nada vale: mas talvez lhe sirva para uma $1^{\mathrm{a}}$ orientação (...) (RP, 13-XII-1925).

Na penúltima carta da série, escrita em onze de maio de 1926, a temática sobre fontes históricas, arquivos e documentos continua recorrente na correspondência entre Rocha Pombo e Câmara Cascudo. Embora se queixasse da tentativa do jovem amigo em fazer o velho historiador "meter-se na Torre do Tombo e até na de Londres", em busca de fontes para fundamentar suas pesquisas históricas, também se utiliza da correspondência com Cascudo para se atualizar sobre as coisas do Rio Grande do Norte:

Diga-me uma coisa: que mal tenho feito neste mundo para que v. nutra o desejo de metter-me na Torre do Tombo, e até na de Londres, e nesta idade em que tanto preciso de ar e de luz? Ah! Maldade de amigo jovem!

(...) Vejo tambem em outro $n^{\circ}$ da Imprensa o seu artigo O Rio Gr. É o Potengiy. Muito interessou-me porque me trouxe uma novidade. Peço- 
lhe que veja si; possivel mandar-me o $\mathrm{n}^{\mathrm{o}}$ da República, em que vem transcripto, o trabalho do dr. Nestor Lima. Dar-se-á mesmo que o Rio Gr. seja o Assú? Quero ver. (RP, 11-V-1926).

O aspecto evidenciado na última carta da série, escrita em 1928 é a surpresa de Rocha Pombo em descobrir que o jovem amigo Câmara Cascudo iria assumir a função de professor, pois acreditava que o mesmo já o era desde muito tempo:

(...) póde ficar certo de que receberá (...) tudo que lhe possa interessar na função que vai assumir, sr. professor... E eu que pensava que v. já era mestre da matéria desde muito! (RP, 20-II-1928).

Em 1928, nomeado pelo presidente Juvenal Lamartine, Cascudo assumiria as funções de professor interino de História do Atheneu-Norte-Rio-grandense. Já ensinava, aliás, a matéria em colégios e cursos particulares. Era aquela, porém, a sua entrada no magistério estadual oficial. Professor de cursos secundários até à Universidade, eis uma de suas atividades centrais, nos domínios da província (COSTA, 1969, p. 26), tal qual afirmou Cascudo em um de seu livro de memórias:

Professor particular em 1920, oficial em 1928, aposentado em 1966 na Faculdade de Direito, dirigi o Atheneu Norte-Rio-Grandense e a Escola Normal, ainda ‘ensinando' na Faculdade Filosofia, Instituto de Música, Colégio D. Pedro II, Marista, N. Sra. Das Neves. Dei cursos sobre Cultura Popular nas Universidades Federais, em natal, João Pessoa, Recife, Fortaleza. Excluo conferências de caráter didático. Continuo falando aos rapazes e moças que enchem a minha salinha de livros ouvindo a voz que ainda não se apagou. Ensinança gratuita e recíproca, permitindo perceber a jovem mentalidade contemporânea (CASCUDO, 1998c, p. 24).

A tese apresentada para o ingresso no magistério público, em 1932, versava sobre a discussão bizantina a respeito do acaso ou não da intencionalidade no descobrimento do Brasil, tema apaixonante para muitos historiadores de então (NEVES, 2002, p. 72):

Com sua entrada no magistério estadual, tornou-se professor efetivo de História da civilização, em 1932, com apresentação de duas teses 
aprovadas com distinção. Uma 'tese sorteada' que trata da 'Origem do homem americano - sua evolução política e social - astecas e incas', e a outra 'tese de livre escolha' que discute 'A intencionalidade no descobrimento do Brasil' editadas posteriormente, em livros e artigos. Perderiaa cadeira com o 'golpe' de Getúlio Vargas, mas voltou à cátedra pelo imperativo constitucional (GICO, 1998, p. 40).

As respectivas teses e as mensagens demonstradas na correspondência de Rocha Pombo, revelam alguns aspectos de sua pena de historiador, entre os quais a paixão pela busca das origens, a erudição, a certeza de que, nos documentos empoeirados guardados nos arquivos, moram - adormecidos - a verdade histórica, a vocação polêmica, o desejo de construir a pátria pela circunscrição - o mais exato possível - de suas gestas heroicas e a função do historiador como testemunha. Além de inúmeras crônicas e escritas breves dedicadas a biografar personagens célebres, Cascudo escreveu livros biográficos, em especial, dedicados a personagens ligadas à monarquia no Brasil, e por sua relação com a família imperial, como é o caso do Conde d'Eu (NEVES, 2002, p. 74-75), que, como sabemos foi duramente criticado por Mário de Andrade, sendo, entretanto (et pour cause...), muito bem recebido por Pedro de Orleans Bragança e Guilherme Auler no período de sua publicação.

\subsubsection{Pedro de Orleans Bragança (1924-1938) e Guilherme Auler (1942-1962)}

Ao iniciarmos a secção final deste capítulo, faz-se necessária a explicação sobre a tomada de conhecimento dos respectivos correspondentes e da relevância dos mesmos para divulgação da produção historiográfica de Cascudo. O primeiro deles, Pedro de Orleans Bragança, ocorreu por intermédio da leitura do livro de memórias $\mathrm{Na}$ Ronda do Tempo (1998b), onde Cascudo informa que no dia vinte e um de janeiro de 1969, teria almoçado no Jockey Club do Rio de Janeiro. "com S.A.I. Dom Pedro Henrique" e recorda que "Em março de 1963, o Príncipe e eu [Cascudo] estávamos no bojo de um avião, voando para Lisboa. Ele rumo da Alemanha, visitar a sogra. Eu [Cascudo], na pista da África Oriental". Finaliza o relato informando sobre o convite de Pedro de Orleans Bragança para Cascudo fosse visita-lo em sua residência em Vassouras, RJ (CASCUDO, 1998b, p. 61). Outra referência se deu através de uma carta escrita por 
Cascudo para Mário de Andrade em nove de dezembro de $1925^{61}$; na carta, Cascudo confessou que embora recebesse cartas de todos os lugares do mundo, o amigo paulista era de seus correspondentes o predileto, mesmo diante de carta de Sua Alteza Imperial, Pedro de Orleans Bragança:

Voltando ontem de Recife encontrei um monte de cartas e uma pilha de livros. Livros mandados vir de Paris e outros presenteados pelos camaradas argentinos. E uma carta sua. E hoje recebi outra a lápis. E me esqueci de olhar o resto da correspondência. E fica S. A. R. e I. o sr. Pedro de Orleans Bragança esperando que eu responda a um outro príncipe amigo e mais meu. Fiquei desolado com a notícia de sua saúde (...) (CC, 9-XII-1925, apud, CASCUDO, 2010a, p. 78).

O segundo correspondente veio através da leitura de uma dos livros sobre a correspondência de Câmara Cascudo, trata-se de Câmara Cascudo do Potengi ao Piabanha (1989), organizado por Francisco de Vasconcelos, que o apresenta da seguinte maneira:

\footnotetext{
Câmara Cascudo do Potengi ao Piabanha não é o corpo presente. É o espírito do Mestre transladado da sua ribeira a esta serra da Estrela e aqui se abrindo em notas e comentários sobre a trajetória luminosa, em intensa colaboração na imprensa local, na ponte epistolar que manteve com seus pares e amigos mais diletos, também circunstancialmente radicados aqui.

Mas afinal que forças, que energias aproximaram o Potengi ao Piabanha através da pena heráldica de Luiz da Câmara Cascudo?

(...)

Teria sido Petrópolis, fora do torrão potiguar a única urbe a ser contemplada com a embaixada cultural de Mestre Cascudo? (VASCONCELOS, 1989, p. 02).
}

Comecemos nossa argumentação em torno do segundo questionamento apresentado por Francisco dos Vasconcelos. Certamente, Petrópolis não foi a única

\footnotetext{
${ }^{61}$ Posteriormente, também verificamos referência ao mesmo em passagens da correspondência de Cascudo e Inojosa no ano de 1969. Na primeira menção feita em carta de treze de outubro de 1969, Cascudo solicita a Inojosa que publique um artigo de sua autoria sobre Pedro de Orleans Bragança no jornal $O$ Meio-Dia de propriedade do amigo. A segunda e última alusão ocorreu na carta de vinte e um de novembro de 1969, onde Cascudo questiona se o artigo havia sido publicado (Cf. ARAÚJO, 2012, p. 119; 121).
} 
cidade a ser contemplada com contribuições de artigos para a imprensa local. Como se sabe, Cascudo contribui com o corpo editorial de várias publicações relevantes (ou nem tanto!) não só no Brasil, como no mundo. Voltando à primeira questão, podemos dizer que entre as décadas de quarenta e sessenta do século XX, Cascudo contribuiu no jornal A Tribuna de Petrópolis, de propriedade da família Orleans e Bragança e dirigido por Guilherme Auler. Antes disso, em Recife, meados de 1922, Auler lançava o mensário Monarquia, um pouco depois, Fronteiras, Correio Imperial e Tradição; sendo todas essas publicações ligadas ao movimento patrionovista, que pregava a implantação do Terceiro Reinado, com Pedro de Orleans e Bragança como possível imperador. Auler é descrito por Vasconcelos da seguinte maneira:

\footnotetext{
Guilherme Auler, por conseguinte, ao se fazer homem, estava definitivamente balizado por elementos doutrinários, que marcariam profundamente sua personalidade pelo resto de sua curta mas operosíssima existência. Seu temperamento intransigente, fê-lo homem brigador e com tendências para as radicalizações. Católico fervoroso, monarquista e direitista, escoimou de sua roda os não que rezavam por sua cartilha, embora paradoxalmente, no fundo, apreciasse os espíritos ecumênicos e universais (VASCONCELOS, 1989, p. 06).
}

Embora Câmara Cascudo do Potengi ao Piabanha (1989) traga a transcrição de cartas de Câmara Cascudo enviadas ao próprio organizador, a Sílvio Julio e Maria Elvira Macedo Soares, que no geral versaram sobre os temas do folclore e da cultura popular, a obra disponibiliza alguns artigos de Câmara Cascudo que tratam de temas ligados ao pensamento monárquico: Por quem dobram os sinos da giralda? (8 de janeiro de 1950); Velho rei, novo exemplo (13 de janeiro de 1950); O rei Faruk El Bassir (2 de junho de 1951); D. Elisabeth a excelente senhora (17 de junho de 1951); A noiva russa de D. Pedro II (12 de outubro de 1952); Recursos do Rei verba pequena (1 de janeiro de 1957) (VASCONCELOS, 1989, p. 55). Não analisaremos os respectivos artigos, mas por intermédio desta breve menção, pretendemos apontar a aproximação de Cascudo com a ideologia política professada pelo editor da Tribuna de Petrópolis, ou seja, a associação com o movimento patrionovista, que como vimos acima teve um caráter monarquista, direitista e conservador católico. 
Feitas estas breves considerações, e nos voltando para os documentos levantados no Instituto Ludovicus - Câmara Cascudo, temos seis cartas de Pedro de Orleans Bragança, escritas entre 1924 a 1938, e quatro cartas de Guilherme Auler, enviadas entre os anos de 1942-1944 e 1962. A série de cartas do primeiro correspondente se insere no $1^{\circ}$ momento do recorte temporal da correspondência de Mário e Cascudo. Já no que compete ao segundo, embora a última carta transcenda em vinte anos a segunda fase da respectiva correspondência, perceberemos que a aproximação de Cascudo com o pensamento conservador não foi algo momentâneo, mas que perpassou todo o conjunto de sua obra.

A primeira carta de Pedro Orleans Bragança, enviada em doze de novembro de 1924, traz um voto de agradecimento a Cascudo por ter mandado rezar missa pelo segundo ano de aniversário do falecimento de seu saudoso pai Gastão de Orleans, o Conde d'Eu. Responde a um questionamento feito por Cascudo sobre a possibilidade de o mesmo ter escrito algum livro a respeito da Guerra do Paraguai, afirmou que ele não tivera o intento. Por fim, acusa o não recebimento de dois livros anunciados em carta enviada por Cascudo em vinte e oito de agosto do respectivo ano:

Agradeço penhorado a missa que mandou diser ao dia de segundo anniversario do falecimento do meu saudoso Pae.

O meu Pae não realizou o intento de escrever um livro sobre a guerra do Paraguay.

Até hoje não recebi os dous livros que me anuncia na sua carta de 28 de Agosto. Terei muito praser em lel-os (POB, 12-XI-1924).

A segunda carta, que possivelmente é o documento a que Cascudo fez referência na correspondência com Mário de Andrade, foi escrita no dia vinte e três de outubro de 1925; nela, vemos Pedro de Orleans Bragança agradecer pelo envio de uma carta de Cascudo remetida em dezenove de agosto do respectivo ano; aproveita a ocasião para agradecer pelo envio dos "seus interessantes livros". O neto de D. Pedro II agradece também pela mobilização de Cascudo frente às autoridades locais com a intenção de comemorar o centenário do nascimento do imperador, com a inauguração de um monumento em sua memória na cidade do Natal, como a tentativa de homenagear seu pai numa placa de uma de suas ruas. Pedro de Orleans ainda agradece o convite de se fazer presente nas comemorações de dois de dezembro - data do $1^{\circ}$ centenário de 
nascimento de D. Pedro II -, finaliza a carta solicitando a quem poderia recorrer para a realização do intento:

Muito agradeço-lhe sua amável carta de 19 de Agosto assim como seus interessantes livros. Só respondo-lhe agora por tel-a recebido pouco antes de minha partida para o Brasil.

Vejo por sua carta e muito me regozijo que o Sr. tenha agitado a idea de comemorar o centenário do nascimento de I. M. D. Pedro II pela inauguração d'um monumento à sua memória na cidade de Natal, tambem folgo saber que em breve o nome de meu saudoso Paes sera lembrado numa placa d'uma das ruas da cidade.

Quanto a sua proposta de fazer-me representar nas manifestações e cerimonias de 2 de Dezembro, aceito-o com muito gosto, mas não conhecendo pessoas (sic.) peço-lhe que me indique a quem poderia pedir este obsequio (POB, 23-X-1925).

Em levantamento realizado, não conseguimos confirmar a participação de Pedro de Orleans Bragança naquelas comemorações. Porém, encontramos uma fotografia do monumento a D. Pedro II na atual Praça João Tibúrcio. A foto é da solenidade de inauguração do busto de D. Pedro II, patrono da praça, que então levava seu nome, e ocorrida no dia do seu centenário, 2 de dezembro de 1925. Na foto, aparece o Major Honorário João da Fonseca Varella, veterano da Guerra do Paraguai. Atualmente, o monumento faz parte do acervo do Memorial Câmara Cascudo. No que diz respeito à nomeação de uma das ruas da cidade do Natal com o nome de Gastão de Orleans ou Conde d'Eu, constatamos através de pesquisa realizada sobre a toponímia das ruas e avenidas que a iniciativa não foi concretizada ${ }^{62}$.

Em uma terceira carta de vinte e nove de maio de 1930, verificamos que apesar de esparsa, a correspondência manteve certa regularidade, pois as cartas de Pedro de Orleans fazem, no geral, menção a outras cartas que foram enviadas por Câmara Cascudo. A carta em questão menciona o recebimento de uma missiva cascudeana do dia nove de outubro de 1929. Nela, percebe-se que Cascudo fez a solicitação a Pedro de Orleans de documentos para estudos sobre a família real brasileira, que lamenta não ter encontrado de imediato um retrato de sua mãe - a Princesa Isabel - para enviar-lhe, mas

\footnotetext{
${ }^{62}$ Para ver a fotografia, acesse: https://www.flickr.com/photos/memoriaviva/171335713/in/photostream/; Sobre a situação atual da praça como da condição do busto de D. Pedro II como propriedade do acervo do Memorial Câmara Cascudo, ver: http://tribunadonorte.com.br/noticia/monumentos-de-natal-sofrem-como-abandono/110336 Disponíveis em: 05/11/15.
} 
promete que a posteriori, seguiria pelo correio. Trata de outro possível extravio, desta vez, referindo-se à plaquete do discurso que Cascudo pronunciou no Instituto Arqueológico Pernambucano sobre D. Pedro II ${ }^{63}$. Pedro de Orleans faz menção ao recebimento de alguns números do jornal Nova Pátria, sugestão de Cascudo que em sua opinião era "simplesmente literário e com o bom intuito" de divulgar o pensamento monárquico no país. O correspondente ainda fala sobre o impacto das eleições presidenciais de $1930^{64}$, e do clima de intranquilidade demonstrado nos jornais brasileiros com a publicação de telegramas na imprensa internacional, considerando uma "desgraça para nossa Patria":

Só agora venho agradecer-lhe sua boa carta de 9-10-29 e peço-lhe muitas desculpas pelo atrazo em responder-lhe, mas esperava sempre a occasião de mandar-lhe alguma cousa para seu studio, mas não me foi possivel arranjar um retrato de minha Mãe que queria enviar-lhe e que segue pelo mesmo correio.

(...) Não recebi a 'plaquete' do discurso que pronunciou no Instituto Archeologico de Pernambuco sobre D. Pedro II: Espero que não se tenha estraviado.

Já recebi alguns numeros do Jornal Nova Patria é como diz simplesmente litterario e com muito bom intuito, mas não sei se continuou pois não o tenho mais recebido.

Vejo pelos jornaes do Brasil que infelizmente as ultimas eleições presidenciaes não trouxerão tranquilidade no Paiz e pelos telegrammas aqui publicados houve em varios logares lutta entre forças do governo e descontentes. É uma desgraça para nossa Patria (POB, 29-V-1930).

Na quarta carta, datada de dezessete de setembro de 1930, vemos referência à leitura de texto de Cascudo que versava sobre a "Casa de Orleans" ${ }^{65}$. Nessa carta, Pedro de Orleans Bragança afirmou que um dia, alguém deveria fazer uma biografia sobre a ação do Conde d'Eu no Brasil. Como já sabemos, Cascudo tomou para si tal

\footnotetext{
${ }^{63}$ Cf. CASCUDO, L. da C. Sôbre o Sr. Dom Pedro II. R. Inst. Hist. E Geog. Rio G. Norte, 25/6: 201-14, 1928/9 - 'Conferência de Luís da Câmara Cascudo, em Recife, como orador oficial do Instituto Archeológico Pernambucano, na comemoração do primeiro centenário de nascimento do Sr. D. Pedro II, em 1825' (MAMEDE, 1970, p. 557).

${ }^{64}$ Disputadas por Júlio Prestes e Getúlio Vargas em meados de março do respectivo ano, como se sabe, o clima será levado ao máximo com o assassinato de João Pessoa, desencadeando posteriormente a revolução de 1930.

${ }^{65}$ Através da leitura do documento, não fica claro se trata de uma carta enviada, ou matéria jornalística versando sobre o respectivo tema. Fizemos uma busca no livro Luís da Câmara Cascudo 50 anos de vida intelectual (1918-1968) de Zila Mamede (1970) e não encontramos nenhuma referência a respeito.
} 
projeto, e com mais três anos à frente, chegaria a cabo a obra. Outra informação relevante é que Pedro Orleans trata de suas lembranças do dia em que passou na companhia de seu pai em Natal, embora o texto não fixe dados em torno de datas específicas, comenta sobre a modernização da cidade, que na sua concepção deveria ser bem outra àquela que visitara antes. Pedro de Orleans Bragança finalizou a carta desejando que o estado do Rio Grande do Norte estivesse apaziguado após a revolução e que não tivesse sofrido muito com a crise:

Li com muito interesse a sua noticia sobre a 'Casa de Orleans' que está exacta. Naturalmente apreciei com particular prazer o que se refere ao meu querido Pae. Tudo quanto o Snr. Diz sobre elle é muito justo. Espero que algum dia seja escripta uma biografhia completa de sua acção no Brasil.

Em todo caso me causa prazer que de alguns annos para ca justiça ja se tenha feito dos serviços que elle prestou a nosso Paiz.

Lembro-me sempre com muito prazer do dia que passei em Natal e do accolhimento tão amavel que lá recebemos; (...) A cidade deve ter tomado muito incremento com a importância que tomou vindo a ser o porto para as vias aerias da Europa para a America do Sul.

Espero que no estado do Rio Grande do Norte esteja tudo agora apaziguado depois da revolução e que não tenha sofrido com a crise (POB, 17-IX-1931).

No decorrer do projeto de escrever a biografia do Conde d'Eu, e na busca de fazer justiça à memória de seu biografado frente aos "serviços que elle prestou a nosso Paiz", vemos que, em 29 de junho de 1933, Câmara Cascudo instalou em Natal o Centro de Cultura Social Conde d'Eu, e o então professor e jornalista definiu as finalidades daquele centro de orientação monarquista. Nas palavras de Cascudo, a instituição "estaria exclusivamente voltada ao estudo e à observação dos problemas atinentes ao desenvolvimento da pátria comum, sem função política regional ou geral, antes reunindo notações para um regime que integre o Brasil em suas relações de paz, de garantia, de labor e de honestidade". Também sinalizou o modelo de monarquia idealizado pelos fundadores do Centro Conde d'Eu (MARSON, 2013, p. 80):

(...) o Império sonhado não podia ser a Monarquia latifundiária, capitalista e burguesa de 1889 e sim o Estado Corporativo; em vez do domínio de uma classe exclusiva sobre todas as outras, teríamos a 
convergência produtora de todas as atividades para o vértice único da Grande Pátria uma e soberana em sua expressão indivisível de Religião, Raça e Família (CASCUDO, 1933)

Os parâmetros delimitados para a instituição e, sobretudo, para a monarquia por ela pretendida se fundamentaram na conciliação de expectativas do orador para o presente - afinadas com princípios monarquistas, questionadores tanto do liberalismo quanto do marxismo -, com reminiscências do passado idealizado, remetidas a episódios bem precisos da história do império luso-brasileiro, remontados através da produção historiográfica de Câmara Cascudo. Na análise de Izabel Marson (2013), nesta busca empreendida por Cascudo, ressaltam-se três preocupações: a primeira demonstra os vínculos, afinidades e a continuidade entre as instituições monárquicas e uma tradição europeia, valorizada das premissas de ordem, de hierarquia e de espírito corporativo, tradição que foi (re) criada na experiência brasileira durante o período da colonização. A segunda, recusar orientações do republicanismo girondino, do liberalismo individualista, "capitalista, latifundiário e burguês de 1889”, do socialismo e do marxismo. Uma terceira preocupação explicita restrições ao hábito de se copiar no Brasil práticas liberais estranhas às instituições nacionais. Essas reflexões históricas possibilitaram a Cascudo externar essas expectativas e, ao mesmo tempo, desenhar imagens de dois impérios: um que havia sido e outro que poderia ter sido ou, ainda, vir a ser (MARSON, 2013, p. 81-82).

Das últimas cartas escritas entre vinte e oito de dezembro de 1935 e a escrita em dezenove de janeiro de $1938^{66}$, só nos ateremos aqui a breve passagem da quinta carta, que demonstra a tentativa de Cascudo de informar Pedro de Orleans Bragança sobre a articulação política dos movimentos de ideologia monárquica no Brasil ("patronovistas" e "acção monarchica brasileira"), durante o ano de 1935:

Já era conhecedor das notícias que o Senhor me dá sobre a divisão dos

'Patrianovistas' e da 'Acção Monarchica Brasileira', Deus queira que tudo se arrange e que a união se faça em breve para o triumpho da paz e a felicidade do Brasil (POB, 28-XII-1935).

\footnotetext{
${ }^{66}$ Em linhas gerais, tratam de questões particulares, portanto, não serão aqui abordadas. O mesmo critério será empregado em relação à carta de Guilherme Auler de 12-XI-1944.
} 
Embora Mário, em carta de nove de junho de 1937, tenha confessado a Cascudo que considerava a monografia sobre o Conde d' Eu 'um assunto tão desimportante, uma figura de nenhum alcance fundamental para pesquisar tantos dados e dadinhos sobre ela!" (MA, 9-VI-1937, apud, CASCUDO, 2010, p. 293), vemos que Guilherme Auler, em carta de dez de março de 1942, laureava Cascudo pelo feito, a "reabilitação da veneranda figura do Príncipe Gastão de Orleans, através do seu excelente livro [o' Conde d'Eu]". O motivo de tanto entusiasmo se devia ao fato de comunicar Cascudo sobre a notícia dos festejos e celebrações do $1^{\circ}$ centenário do nascimento do Conde d'Eu, tendo sido este "benemérito gesto do Gel. Dutra", que teria acatado uma sugestão que lhe havia sido enviada em memorial pelos "Amigos de Tradição", jornal de ideologia monarquista com o qual Auler e Cascudo parecem ter contribuído. Neste projeto de comemorações, Auler faz questão em frisar que o livro de Cascudo teria sido o primeiro a aparecer sobre o assunto e também o único, tendo em vista que o livro de Alberto Rangel teria sido proibido de circular, por intervenção do Ministério da Guerra, "devido a umas referencias pouco respeitosas do Autor ao Duque de Caxias", sendo a produção de Cascudo a "única obra a ler e divulgar", acreditava Auler que o escritor potiguar certamente se associaria às comemorações:

Apresso-me a lhe escrever sobre um assunto que grande satisfação nos proporciona. Conforme voce deve ter lido no noticiário telegrafico dos jornais, o Sr. Ministro da Guerra determinou que o dia 28 de abril, quando transcorre o primeiro centenário do nascimento do Conde d'Eu fosse festejado e celebrado por todas as forças do Exército, como homenagem a esse Marechal do Exercito. Ora, esse benemérito gesto do Gel. Dutra obedeceu a uma sugestão que lhe foi enviada em memorial pelos nossos 'Amigos de Tradição' (...)

(...)

Você, a quem se deve a reabilitação da veneranda figura do Principe Gastão de Orleans, atravez do seu excelente livro certamente, extará exultando de alegria, como todos nós.

Aliás, por uma coincidencia interessante, o seu livro que é o primeiro aparecido, também se tornou o único, pois o de Alberto Rangel foi no ano passado proibido de circular, por intervenção do Ministerio da Guerra, devido a umas referencias pouco respeitosas do Autor ao Duque de Caxias. Assim, o seu 'Conde d'Eu' é a única obra a ler e divulgar.

Certamente, voce se associará ás comemorações (GA, 10-III-1942). 
Em carta de primeiro de abril de 1942, Auler acusa o recebimento de cartão enviado por Cascudo. Na pressa para os preparativos dos festejos do centenário, envia os documentos mencionados na carta anterior. Uma das iniciativas que Guilherme Auler tomara frente à filial da Editora Nacional em Recife para homenagear o príncipe era uma vitrine ornamentada com os livros Conde d'Eu e Viagem Militar ao Rio Grande do Sul de Cascudo e Guilherme Auler respectivamente. Na ânsia de que as solenidades não ficassem apenas nas festas militares, questiona Cascudo se o IHGRN faria algo, ou se mesmo Cascudo não escreveria algum artigo na imprensa do sul país:

\footnotetext{
Recebi seu cartão que agradeço.

Envio incluso copia dos dous documentos sobre o Centenário do Conde d'Eu. (...)

Já me entendi com a filial da editora nacional, que vai homenagear o

Principe com uma vitrine ornamentada onde apenas figurarão os livros 'Conde d'Eu' e 'Viagem militar ao Rio Grande do Sul'.

Tenho trabalhado um pouco afim de que as solenidades não fiquem apenas nas festas militares. O Instituto Histórico daí fará alguma coisa? E você não escreverá nenhum artigo na imprensa do sul? (GA, 1-4-1942).
}

Infelizmente, não conseguimos encontrar outras cartas envidas por Auler para ver os desdobramentos desse projeto das comemorações do centenário de nascimento do Conde d'Eu. Tão pouco, conseguimos detectar algum artigo de Cascudo que versasse sobre o respectivo tema. No entanto, vale frisar aqui mais uma vez que os elementos discutidos colocam outras trajetórias e projetos intelectuais por parte do historiador potiguar, e demonstram como foi precipitada a leitura proposta por Veríssimo de que Cascudo teria sido exclusivamente um modernista de primeira hora, e que a tão falada "carta terrível” de Mário teria definido, sem mais, os rumos das pesquisas cascudeanas pelo tema do folclore e da cultura popular, argumento reificado pela produção historiográfica posterior por muito tempo.

Na última carta, vemos Auler tratar de um convite feito por Cascudo para compor uma obra coletiva sobre alimentação. Trata-se de Antologia da alimentação no Brasil (1977), lançado logo após a publicação do seu História da Alimentação do Brasil (2004) entre os anos de 1967 e 1968; pelo prefácio da obra, é possível perceber que o projeto foi desenvolvido entre os anos de 1964 e 1974; a carta em questão foi escrita em 
vinte e nove de setembro de 1962, e Auler viria a falecer em 1965. Nela, o correspondente demonstra conhecer o interesse de Cascudo sobre a alimentação, referindo-se à leitura de um artigo de Assis Chateaubriand tratando ainda do levantamento de fontes históricas sobre os hábitos alimentares do segundo império solicitado por Cascudo; misturando em seu relato a busca documental para suas pesquisas e o apetite alimentar, manda alguns exemplares para lhe despertar a gula, e convida o amigo para ir à Petrópolis para melhor "saborear o petisco histórico". Finaliza a carta pedindo maiores informações sobre o texto que Cascudo desejava que ele produzisse, pois até aquele momento, nada havia escrito sobre a temática:

Já sabia de suas atividades alimentares e culinárias, via Assis Chateaubriand, pela leitura de 'O Jornal' do Rio de Janeiro.

Aqui temos no ARQUIVO DA SUPERINTENDENCIA, um colosso de material virgem á sua espera. Voce bem pode julgar-se num harem. Mando-lhe junto, a relação dos Codices nº 314 a 336 para despertarlhe a gula.

Alem desses Codices, ha mais o recheio de 90 grandes pacotes, contendo balancetes mensais e respectivos anexos. Só de faturas comercias de fornecedores do Rio e de Petropolis, há centenas e centenas. Mando-lhe duas para aguçar-lhe o apetite.

Portanto, aqui estou para servir-lhe. Mas, porque Voce mesmo não vem saborear o petisco histórico aqui em Petrópolis?

(...)

Escreva-me e diga o que deseja afinal. Até hoje nada escrevi ou pesquisei, diretamente, sobre o assunto dos comes e bebes (GA, 29XI-1962).

Neste ponto, ocorre o mesmo com o que houve nas cartas que trataram do centenário de nascimento do Conde d'Eu; não há mais documentos na série de correspondência de Guilherme Auler e Câmara Cascudo, além dos supracitados. Entretanto, a contribuição de Auler para a Antologia da Alimentação no Brasil é sinal de que este debate pode ter se prolongado um pouco mais. O texto intitulado $A$ "vida" do criado particular do Imperador (1857) versa sobre um requerimento do criado José Maria dos Anjos Esposel de seis de abril de 1857, detalhando as despesas alimentares que o mesmo tinha para com os seus familiares, tentando justificar o pedido de aumento de seus rendimentos ao Imperador D. Pedro II. Antes de compor a obra, o artigo 
também foi reproduzido com o título de "Revelações de um requerimento ao Imperador", no jornal Tribuna de Petrópolis em 21 de junho de 1964, conforme indicou Cascudo em nota informativa sobre o texto em questão (CASCUDO, 1977, p. 212-214).

Assim, Cascudo encontrou no passado vestígios de um império-origem do "neomonarquismo" e dos grandes impérios que precederam as monarquias do séc. XIX. Para ele, a tradição monárquica brasileira efetiva fora tecida ao longo do domínio colonial português e das primeiras décadas do segundo reinado, obra original dos fidalgos das províncias e dos soberanos da casa de Bragança, permanecendo latente na cultura e nos costumes partilhados pelo povo, apesar da presença postiça das instituições liberais e republicanas. Desse modo, esperava apenas uma ocasião propícia para revelar-se pela ação consequente e bem informada de intelectuais-políticos capazes de compreendê-la e (re) compor, em novas circunstâncias, os naturais vínculos entre a vontade popular e os príncipes perfeitos, herdeiros da casa de Orleans e Bragança, tal qual seu correspondente Pedro de Orleans Bragança, que também foi muito admirado por seu amigo Guilherme Auler (MARSON, 2013, p. 107):

Síntese de educação viril, de fortaleza mental, de coragem física, com a convicção pessoal que o mérito não vem na honra do nome herdado, os filhos do conde d'Eu são valores que se alinham à direita dos fatores cívicos duma raça. Eles honrariam qualquer... (CASCUDO, 1933, p. 143). 


\title{
4. Capítulo III:
}

\section{“ENTRE OS ARTISTAS AMIGOS O MOMENTO BOM DE TERNURA É O APARECIMENTO DE OBRA NOVA":}

a correspondência entre Luís da Câmara Cascudo, Mário de Andrade e Joaquim Inojosa

\begin{abstract}
É incontestável que entre artistas, embora seja isso raro, também podem existir amizades verdadeiras. Os igrejós musicais, as capelas literárias, que no geral são tidos como associações do elogio mútuo, na realidade não são tão odiosos como parecem. (...) Mas como em todas as amizades humanas a dificuldade da permanência consciente do afeto leva a fixação de momentos de ternura, que nem os aniversários, os enterros, etc., entre os artistas amigos o momento bom de ternura é o aparecimento de obra nova (ANDRADE, 1976, p. 175).
\end{abstract}

\subsection{A rede de sociabilidade Mário, Cascudo e Inojosa: os arquivos da criação modernista no Nordeste}

Como já afirmou Sirinelli (2003), todo grupo de intelectuais organiza-se em torno de uma sensibilidade ideológica ou cultural comum e de afinidades mais difusas, mas igualmente determinantes, que fundam uma vontade e um gosto de conviver. São estruturas de sociabilidade difíceis de apreender, mas que o historiador não pode ignorar ou subestimar (SIRINELLI, 2003, p. 248).

Em 1932, no artigo Intelectual - I, Mário estabelece uma crítica aos intelectuais brasileiros que naquele momento, estavam em sua opinião, num ponto que banzava a inteligência brasileira, por serem demasiadamente saudosistas, como "Machado de Assis ${ }^{67}$, Joaquim Nabuco e todos os outros fazedores de Academias celestiais". Apontava ainda que a correspondência desses ilustres seria a mostra do estado de consciência do intelectual brasileiro em sua época:

\footnotetext{
${ }^{67}$ Ao estabelecer uma leitura da correspondência de Machado de Assis em comparação à de Mário de Andrade, Marília Rothier Cardoso (1985) nos mostra que distanciados por meio século, mas reunidos na troca de cartas, Machado e Mário se distinguiriam pelo estilo da escrita epistolográfica: o primeiro mantinha-se rigorosamente dentro das regras convencionais; o segundo desobedecia às normas, buscando inventar nova estilística. Mário aproveitava a meia-privacidade da correspondência, para exercitar a oralidade da escrita, a mescla de temas fragmentariamente enfocados, a quebra de preconceitos desenvolvendo seu projeto de vanguarda. Segundo a pesquisadora, nas cartas, Machado esmerava-se na nota conservadora, quando se correspondia com os amigos. Nas cartas, assinando diretamente seu discurso, Machado de Assis guardava-se de qualquer ousadia (CARDOSO, 1985, p. 62).
} 
Nós estamos ainda exatamente naquele ponto desumano, imbecilmente egoístico em que banzavam a sua inteligência vasta, cultivada, saudosista, Machado de Assis, Joaquim Nabuco e todos os outros fazedores de Academias celestiais. A correspondência desses ilustres é a mostra do estado da consciência ainda contemporâneo do intelectual brasileiro. Que miudeza, puxa! O mais que a gente pode falar é que a miudeza está bem escrita. (...) E se carteavam, carteavam, num trocatroca suavíssimo de melodias. O que carteavam? Carteavam se elogiando com medida, mais por amor da mesura que por felicidade do amigo, sem nenhuma paixão pela vida, sem nenhuma generosidade intelectual (...). (ANDRADE, 1976, p. 515-516).

Mário criticou a artificialidade desta estilística, pois acreditava na necessidade de sinceridade e despojamento do "eu" nos textos epistolográficos. Contudo, não deixa de expor no artigo Epistolografia (1930) que toda sinceridade da escrita epistolar é insincera, como podemos constatar no fragmento a seguir:

O meu amável senhor está indignadíssimo com a cachorra da Justiça, sofrendo mortes de ambição por causa dos cobres perdidos, está que é uma fera. Bom, pois então vamos dar-lhe a força de si mesmo, enganando a ele e a nós que o meu amável senhor tem grande indiferença pelos bens desta vida. Reparem: tudo isto é sinceríssimo, humano e respeitável. Sai dum jato na carta sincera. Depois analisando friamente é que a gente percebe que a sinceridade, apesar de sinceríssima, é insincera, em resultado: sinceridade e insinceridade são palavras vãs. Não correspondem a nenhuma verdade inamovível (ANDRADE, 1976, p. 260-261).

Para Marcos Antonio de Moraes (2007a), esse texto funciona como uma espécie de teoria da carta às avessas. $\mathrm{O}$ cronista manifestou o desejo de compreender a lúdica potencialidade dos modelos de cartas que conseguem ocultar, sob formas estereotipadas, os mais contundentes sentimentos. A observação do espaço de encenação deste tipo de missiva, ornamentadas com frases de efeito possibilita que Mário desenvolva alguma ponderação sobre o aspecto central da escrita epistolar, a "sinceridade" filtrada pela linguagem da carta. Ao sublinhar o fosso entre o que se diz e o que se queria dizer realmente na carta, destaca as estratégias do gênero epistolar, apontando neste a inelutável imanência da máscara (MORAES, 2007a, p. 75). 
De acordo com Sérgio Miceli (2012), a atuação de Mário como liderança intelectual de estatura nacional pode ser bem aquilatada pela correspondência mantida com escritores e artistas brasileiros. Entre seus destinatários favoritos incluem-se maiorais do surto modernista no país - como Carlos Drummond de Andrade e Manuel Bandeira; poetas contemporâneos - Ribeiro Couto, Murilo Mendes, Henriqueta Lisboa; artistas consagrados pela maré reformadora - Anita Malfatti, Tarsila do Amaral, Cândido Portinari, Heitor Villa-Lobos; editores de revistas literárias prestigiosas Sérgio Buarque de Holanda e Prudente de Moraes Neto (Estética), Murilo Miranda (Revista Acadêmica); dirigentes da política cultural oficial - Augusto Mayer, Rodrigo Melo Franco de Andrade; sem falar nos parentes e dezenas de outros intelectuais. A leitura dessa volumosa correspondência atesta a trama de relacionamentos e interações, a qual proporciona um retrato fidedigno da inteligência brasileira nas décadas de 1920, 1930 e até meados da década de 1940, de passagem entre o esvaziamento da cultura oligárquica, nucleada num corpus predominantemente literário, pulsante nas obras modernistas, e as balizas ainda latentes de uma cultura universitária profissionalizada (MICELI, 2012, p. 112-113).

Francisco Correia nos mostra que é possível interpretar o exercício das cartas como expressão do ser predominantemente dialógico que foi o autor de Macunaíma. Impossibilidade de solidão, apelo ao outro, busca de uma arte que refletisse o homem em sociedade - são decorrências de um mesmo impulso fundamental que visava a estabelecer a ponte com o próximo. Daí, na sua pregação, as cartas se constituírem em complementos das obras, veículos explícitos das intenções ético-estéticas do escritor (CORREIA, 1997, p. 193-194).

Desse modo, concordamos com Marcos Antonio de Moraes (1997), quando afirma que a epistolografia, em Mário de Andrade, incorpora limites didáticos e o professor faz da carta um instrumento de ensino. O pedagogo é o doutrinador paciente dos colegas de geração, oferecendo o conhecimento técnico e ideológico das tendências modernistas, assimilados nos livros e revistas europeias. Depois, lia atenciosamente tudo o que lhe enviavam os moços de outras gerações, procurando-o com poemas, romances ou apenas partilhando com ele indecisões diante da vida. Mário se impunha como intelectual que não empregava o tom altíssono e pedante dos "igrejós" para compartilhar o saber (MORAES, 1997, p. 186).

Tomando o exemplo de Mário de Andrade, podemos constatar que a troca epistolar foi uma prática bastante difundida ao longo do Modernismo brasileiro entre 
muitos intelectuais que fizeram parte desse movimento. Por ter sido tão pródiga, as cartas que puderam ser preservadas constituem-se hoje em importante fonte de pesquisa, consideradas a variedade e a densidade das discussões que elas encerram: assuntos pessoais mesclam-se a questões literárias, políticas e econômicas; queixas de intrigas entre colegas dividem espaço com comentários sobre estudos ou pesquisas; à apreciação de uma ópera segue trecho de um poema em elaboração; e assim por diante. Esse caráter de relação dialógica, em que se colocava em discussão uma pluralidade de assuntos, é marcado também pela informalidade da escrita e da forma de tratamento dos interlocutores (MACHADO, 2012, p.7):

Estou me lembrando disto porque existe uma espécie de violão da literatura, a que poucos dos nossos milhares de escritores se dedicam, o chamado gênero epistolar. É na verdade, o gênero ideal, de grande nobreza humana porque socializa, aproxima os indivíduos e cultiva a amizade. E ao mesmo tempo, não se publica. Por intermédio das cartas nós podemos dar fuga aos nossos sentimentos e ideais, fazer literatura, mandar contos e crônicas aos nossos amigos, dezenas de sonetos, que serão certamente aplaudidos por eles, de noite e de dia, porque não fazem barulho. (...) ${ }^{68}$ (ANDRADE, 1993, p. 188-189).

O gênero epistolar é uma "espécie de violão da literatura" escreveu Mário de Andrade em “Dona Flor”, crítica publicada no Diário de Notícias do Rio de janeiro, em 1940. Essa definição tão sucinta quanto intrigante vem a propósito de ponderações a respeito do escritor e seu ofício. O violão seria o contraponto do piano, segundo uma anedota verdadeira de um professor de música, conhecido de Mário, que indicava o violão aos alunos de teclado menos talentosos. A carta aparece, assim, estrategicamente, em segundo plano: como exercício que os iniciantes nas letras deveriam praticar antes de se aventurarem no delicado "piano" da criação literária. Era o espaço para o "treino", o "adestramento" da escrita, para enfrentamento diário de problemas "técnicos" da arte

\footnotetext{
${ }^{68}$ Mário de Andrade, poucos dias antes de sua morte, escreveu um pequeno poema que enviou em carta ao jornalista Guilherme de Figueiredo: (...) "Guarda as cartas consigo,/ Nunca mostrar a ninguém./ Não as publicar também. De indiferente ou de amigo/ Guardar ou rasgar. Ao sol Carta é farol" (MA, 17-II-1945, apud, ANDRADE, 1989, p. 163). Segundo Ionta (2007), "Mário teria elaborado poeticamente uma "ética da carta' a de 'guardar as cartas', 'nunca mostrar a ninguém' e 'não as publicar"'. Esses gestos apontados pelo poeta trazem a à baila algumas problematizações que envolvem a questão do caráter público e/ou privado das correspondências, ou melhor, dos critérios normalmente utilizados para distingui-las. Finalizando seu argumento a autora frisou que Mário, com o intuito de resguardar a si mesmo e a intimidade alheia atinge seu ponto alto no desejo expresso em uma carta testamento, de lacrar sua correspondência durante cinquenta anos após sua morte (IONTA, 2007, p. 67-68).
} 
da palavra. Para Mário, a carta conservava, no dispendioso papel de comunicação sem alardes e no silêncio da cumplicidade, "grande nobreza humana", revelando-se o espaço ideal para os enlevos sentimentais e para elaboração do sentimento. Nobilita-a ainda mais o caráter: a carta "socializa, aproxima os indivíduos e cultiva a amizade". Escrever cartas valeria como um conselho aos novos ficcionistas, apressados divulgadores de obras imperfeitas (MORAES, 2007a, p. 110-111).

Neste capítulo voltaremos mais uma vez à correspondência de Mário e Cascudo. Aqui, não abordaremos todo o corpo da correspondência, mas apenas aquelas cartas que foram escritas durante a década de vinte (1924-1928). Faremos a leitura dessa correspondência em contraponto às séries epistolográficas de Câmara Cascudo com Joaquim Inojosa (1924-1926) ${ }^{69}$ e entre Mário de Andrade e Joaquim Inojosa (19241928). Temos como objetivo acompanhar o processo de criação das obras dos respectivos autores à época, bem como o processo de recepção dos ideais modernistas no Nordeste.

Estas outras séries serão agenciadas por intermédio do Relatório de pósdoutoramento de Humberto Hermenegildo de Araújo, Consciência moderna $e$ movimentos: o Modernismo nas cartas trocadas entre Câmara Cascudo e Joaquim Inojosa (2012); das cartas de Inojosa enviadas a Mário, que foram catalogadas no IEB/USP, e dos registros presentes na obra O Movimento Modernista em Pernambuco ${ }^{70}$ de Joaquim Inojosa (1968-1969), que dispõe toda a trajetória da atuação intelectual ligada ao campo do Modernismo, contando com uma documentação exaustiva; conservada e trazida à tona pelo próprio autor. Cremos que a troca de correspondências dos respectivos intelectuais é peça fundamental da engrenagem dessa rede de sociabilidade modernista no Nordeste.

\subsection{A Correspondência de Câmara Cascudo e Mário de Andrade (1924-1928)}

\subsubsection{Recepção e critica de poesias}

Um traço que merece muita atenção no âmbito da troca de missivas nesse período é o de que elas se tornaram um meio eficaz para a circulação de textos inéditos

\footnotetext{
${ }^{69}$ A correspondência entre Câmara Cascudo e Joaquim Inojosa se divide em dois momentos: o primeiro que será analisado neste capítulo e um segundo que por sua vez, é composto de cartas trocadas entre os anos de 1968 e 1984, que serão analisadas no capítulo seguinte.

${ }^{70}$ A respectiva obra será objeto de análise do próximo capítulo, no momento a menção se deve apenas no que diz respeito à documentação aqui evidenciada.
} 
entre intelectuais modernistas. É importante destacar, como nos mostrou Márcia Machado (2012), que se esse não foi um hábito restrito a esse momento histórico, desenvolveu-se de forma considerável nele. É possível verificar, portanto, que escritores trocavam entre si seus textos em processo de elaboração e, na maioria dos casos, solicitavam opiniões a respeito deles. As correspondências trocadas entre os integrantes do Modernismo brasileiro revelam que a partilha do texto inédito estabeleceu-se entre eles como uma prática constante. Mário de Andrade foi, sem dúvida, um desses intelectuais que via na circulação de manuscritos um estímulo para a troca de ideias entre seus pares, é o que se observa no grande volume de manuscritos que enviou, recebeu e comentou (MACHADO, 2012, p. 7; 10).

O ano de 1924 parece ser um marco histórico na divulgação e propagação do movimento modernista: é neste ano que as ideias modernistas irão deixar o eixo Rio de Janeiro/São Paulo, passando a serem divulgadas pelo Rio Grande do Sul, Minas Gerais, e pelo Nordeste em geral. É durante este período que Câmara Cascudo vai participar ativamente da vida literária de Natal e Recife. A correspondência entre Mário e Cascudo terá início, significativamente, neste ano. Em onze de julho de 1924, Cascudo publica, em A' Imprensa, um artigo sobre o autor de Losango Caqui, intitulado O Sr. Mário de Andrade. Esta parece ter sido, de certa maneira, a primeira missiva de Cascudo, sob a forma de carta aberta, que irá provocar o início da correspondência entre os dois (GOMES, 1999, p. 47):

\footnotetext{
Toda essa espafúndia cousa significa o arrojo deste singular temperamento de artista e criador. A sua coragem cifra-se em apresentar-se como é, sem máscara, e dispensando o amável auxílio das citações. De linha em linha voa o pensamento. Paralelo as imagens sobem. Sistema Blaise Cendrars. E a idéia para ser escrita basta ser pensada (...) senhor Mário de Andrade (CASCUDO, 1924, apud, ARAÚJO, 1995, p. 104).
}

A partir da tomada de conhecimento da crítica de Cascudo, Mário irá propor-lhe algo que lhe era habitual, ou seja, solicitar manuscritos ao jovem escritor potiguar. Já na primeira carta que remeteu a Cascudo está a declaração: 
Já o conhecia. O seu nome ficou-me dum artigo lido na revista do Brasil. O seu estilo atual, vivaz, serelepe dá alegria. Entretece a gente. É incisivo. (...)

(...) Gratidão maior que lhe tenho da revelação de mais uma inteligência viva e eficaz. (...) Meu ponto vulnerável é a confirmação das inteligências fortes. Você tocou-me rijo.

Terei sempre interesse em seguir seus trabalhos. Quer mandá-los? (MA, 14-VIII-1924, apud, CASCUDO, 2010a, p. 33).

Cascudo aceita a proposta, tendo em vista que ser admirador de Mário de Andrade seria lugar comum para a intelectualidade de sua época, se julgaria célebre se soubesse da opinião do futuro Macunaíma sobre seus livros:

Para que quer assanhar caixa de maribondo? Conhecer-me? Pois aí vai o pedido audacioso, (...)

Mando meus dois livros. O último Joio é a melhor parte que tenho realizado. O História é história. Publiquei em 1921 o Alma patrícia que João Ribeiro, Afrânio etc. elogiaram e o Osório escoicinhou lindamente. Homem oportuno.

Pelo correio segue o meu credo artístico. Verá o que penso de artes embora seja mais amigo das malas (em espanhol?).

Ser seu admirador é hoje lugar-comum. Muito me julgarei célebre se souber sua opinião sobre os meus livros.

Hoje recebi uma carta do Lobato estranhando a gramática do Histórias que o tempo leva... (o meu filhinho histórico) Veja lá até onde chega o humorismo do Lobato... (CC, 25-VIII-1924, Id. Ibidem, p. 34).

Levando em consideração que correspondência é diálogo e o remetente, em vista de maior ou menor proximidade com seu interlocutor, elege assuntos, experiências e impressões pessoais, vemos que a presença do outro determina também as formas de contar-se, ou seja, Cascudo cria uma mise en scène frente à carta do seu interlocutor, o modernista Mário de Andrade, mesmo que o admire bastante, e se colocando como um escritor estreante, não deixa de enfatizar o seu reconhecimento pela intelectualidade de sua época, onde escritores como João Ribeiro e Afrânio Peixoto recepcionaram e elogiaram sua obra; e ao mostrar que troca correspondência com ninguém menos que Monteiro Lobato, chega a fazer piada com as críticas dirigidas ao Histórias que o tempo 
leva...; não se colocando como um iniciante em busca de conselhos, mas como alguém que está de igual para igual, disposto a compartilhar e discutir suas ideias.

Nesse sentido, como demonstrou Marcos Antonio de Moraes (2007a), a experiência comum de quem escreve cartas não ignora que o carteador se modifica em graus diferentes, moldando-se pela imagem que tenciona mostrar ao outro, reflexo não muito distante das ações sociais que modelam o indivíduo em mil facetas da personalidade. Esse caráter particular e intransferível da carta determina um espaço narrativo subterrâneo, protegido pelo segredo, próximo da "encenação" do "eu", seja de forma consciente ou apenas movido pela intuição (MORAES, 2007a, p. 75).

Para se entender as circunstâncias que envolvem a recepção de manuscritos na correspondência de Cascudo e Mário, é necessário levar em consideração as condições que norteavam o envio de manuscritos: pedido de julgamento ou tentativa de publicação (MACHADO, 2012, p. 40). Condições presentes ao longo de todo o corpo da correspondência. Em carta de vinte e seis de setembro de 1924, Mário dirá em resposta a Câmara Cascudo o sentido de suas considerações:

(...) Creia que sou sincero e não tenho a mínima intenção de lhe ser agradável. Nem me importam teorias, Modernismos etc quando aprecio ou renego. É lógico porém que mais aprecio o que mais vai comigo. O que não impede que eu ainda leia com prazer Matias Aires e Euclides por exemplo. A sua dicção tem pontaria certeira as mais das vezes, Luís da Câmara Cascudo. Gostei imensamente disso. Não será mesmo essa maior conquista dos modernos? (...) Gosto sempre de fazer exemplo comigo mesmo, porque assim não parece que estou a atacar ninguém. (...) (MA, 26-IX-1924, apud, CASCUDO, 2010a, p. 38).

Em quatro de setembro de 1925, Cascudo enviou a Mário de Andrade, do sertão do Rio Grande do Norte, três poemas seus que provavelmente compusera durante sua estadia nesse local. E ao encaminhá-los, Cascudo faz a seguinte solicitação:

Perdoe V. o papel. Estou no meio de vaqueiros e cantadores. Não há luz elétrica. A coisa que me lembra, e detestavelmente o progresso, é meu Ford que está parado debaixo do telheiro (...).

Mando três poemas para V. Leia-os, publique-os. Como quiser. Chamei-os 1, 2 e 3. Se gostar dê-lhes nome pela impressão que 
obtiver. São absolutamente flagrantes autênticos, fiéis. São seus. (...) (CC, 4-IX-1925, Id. Ibidem, p. 60).

Como podemos constatar, Cascudo não apenas compartilhou a recente criação, como a entregou a Mário para que ele lhe desse o destino que compreendesse melhor. Estão presentes na declaração de Cascudo as duas condições de envio de textos apresentadas anteriormente, os pedidos de parecer e publicação. Quanto ao primeiro, é possível constatar que foi colocado de forma implícita. Constatação feita não apenas com base na amizade que começava a se firmar entre os dois, mas pela consideração aos comentários críticos de Mário que Cascudo demonstrou ao longo das cartas que trocaram. Não se pôde encontrar nenhum registro de encaminhamento ou publicação de nenhum dos três poemas nos periódicos da época, embora Mário achasse que eles "poderiam ser aproveitados em alguma revista interessante" 71.

Em carta de quatro de outubro de 1925, onde comentou cada um dos três poemas. Mário deixou claro que não se apropriaria dos poemas, os quais considerou "bons", "enérgicos retos", de acordo com suas palavras, e sobre eles fez uma série de apontamentos. Alertou ao escritor que se debruçasse mais demoradamente sobre os ajustes da escrita, não abandonando os poemas após a primeira redação, pois essa postura estava resultando em um problema de ritmo, o que Mário demonstrou transcrevendo e comentando dois versos do primeiro poema. Já sobre o poema de $\mathrm{n}^{\mathbf{o}} 2$, não apontou nenhum problema, considerando-o o melhor dos três, "excelente como expressão". Por fim, sobre o de $n^{\circ} 3$, julgado por ele como o mais problemático, além de indicar modificações, questionou o emprego do verso livre (CASCUDO, 2010a, p. 6869; MACHADO, 2012, p. 41-42):

O terceiro, não sei adonde que você ou antes o lirismo de você estava com a cabeça, de certo tinha entrado por demais nalguma abrideira bem gostosa, o certo é que a versificação saiu bêbada duma vez. Noto aliás ainda uma certa indecisão no conceito de verso-livre de você. Não é bem verso-livre é verso arbitrário sem justificação nenhuma nem mesmo psicológica (MA, 4-X-1925, Id. Ibidem, p. 69).

${ }^{71}$ Cf. (...) "Olhe, Luís, acho sinceramente que você carece aproveitar aquilo. São três poeminhas deliciosos. Se fizer alguma modificação neles me mande que quero tê-los comigo e talvez aproveitar um dia, se por aqui sair alguma revista interessante”. (...) (MA, 26-XI-1925, Id. Ibidem, p. 75-76). 
Preocupado, talvez, com uma possível reação de desagrado em virtude dos defeitos apontados e das sugestões de alteração, no final de seus comentários alertou a Cascudo que esse era um costume que compartilhava com outros modernistas (MACHADO, 2012, p. 42):

Não zangue não de eu estar propondo mudanças no poema que é seu. O Manuel e o Drummond e uma porrada de outros amigos fazem isso comigo e eu com eles sem nenhuma cerimônia. É lógico que nenhum tem obrigação de aceitar tudo o que os outros propõem. O certo é que eu mesmo devo muito para eles principalmente pro Manuel, que me querendo muito bem é absolutamente impiedoso comigo, não deixa passar nada. Assim também faço com você. Prova de amizade que não obriga você a coisa nenhuma, está visto. E que só serve pra gente ir ficando cada vez mais cutuba e destorcido na arte que escolheu, não acha? Refletir nunca faz mal pra ninguém (MA, 4-X-1925, apud, CASCUDO, 2010, p. 70-71).

Em carta de nove de dezembro de 1925, Cascudo escreve ao amigo afirmando que engoliu a "inspiração para descomê-la em prosa"; considerou um desaforo as críticas, pois em sua opinião apontar uma falha era desmoronar o castelo, e o dele teria vindo abaixo, de todo modo agradecia, pois acabava de perceber que não era poeta, havia "despertado frente ao fato de que o rei é mais bonito nu" ${ }^{72}$ :

Engoli a inspiração para descomê-la em prosa. V. é um assassino. E inda lhe devo o favor. Foi como naquela estória persa, o menino que viu o Rei nu. E eu andava certíssimo de estar vestido tão bem. O que me enfureceu foi o conselho de 'modificar'. Pois modificar o que não significa que um traço, um rabisco, um desenho japonês dizendo coisa alguma que não seja evocação? V. inda apresentou emendas ao projeto... E técnicas. Bandido complicado em erudito. Fiquei furioso. Aqui pelo Norte nós somos furiosamente, liricamente talentosos. Apontar uma falha é desmantelar o castelinho. E o meu veio abaixo como se fosse de poeira. Estou desanuviado. Mais lépido. Com a impressão de ter vencido. E venci uma convicção às avessas. Devo a V. Meti o livro de versos num envelope e sepultei-o no 'inferno' da

\footnotetext{
${ }^{72}$ Referência ao verso da canção O estrangeiro presente no disco homônimo de Caetano Veloso (1989 Elektra/Musician).
} 
biblioteca. Creia que estou sinceramente grato. Até cabeleira eu estava usando (...). (CC, 9-XII-1925, Id. Ibidem, p. 78-79).

Mário ainda insistirá com Cascudo a respeito dos três poemas e sobre sua poesia. Na carta de primeiro de janeiro de 1926, comenta que ele deveria trabalhar suas poesias, pois para o futuro Macunaíma, só as cartas que deveriam ser espontâneas, poesia não, seria como criança, não bastava simplesmente "parir" e "por no mundo", tinha que educar:

(...) Com exceção de minhas cartas não tem trabalhinho meu que não seja pausadamente pensado. E assim é que deve ser. Você está na obrigação de trabalhar a sua poesia, que é boa. E se não fosse boa pode ter a certeza que eu não falava que era. Os três poeminhas que você mandou e que aqui estão guardados e relidos são muito bons. Que custa agora você fazer que eles fiquem mais artísticos, mais perfeitos, se a inspiração vale a pena disso! Você está na obrigação de me mandar logo seus versos pra que eu os leia, tenho vontade deles. E mude sua opinião sobre maneira de fazer obra-de-arte que sobre este ponto de... parir só e não educar depois está positivamente errada (MA, 1 - I - 1926, Id. Ibidem, p. 84-85).

Em doze de março de 1926, Mário volta a instigar Cascudo a retomar seus escritos poéticos e que tirasse o "livro do inferno da biblioteca", o interesse não era só devido à amizade, mas por apreço intelectual, pois tinha fome de ler o que o amigo produzia em poesia. Argumentou que tanto apreciava a poesia cascudeana, que havia tomado um dos "poemas sem nome" para utilizá-lo como exemplo num artigo que estava produzindo para a revista Mocidade - Tendências da Poesia Modernista no Brasil:

(...) Escreva homem e mande coisa! Faz favor, Luís, me mande o tal livro de versos que você estava escrevendo pra eu ler. Juro que tenho interesse não só de amizade mas intelectual nisso e terá ida e volta se você mandar os originais e não cópia. Mande tudo tudo, tenho fome de ler o que você fez em poesia. Agora mesmo escrevi um artigo pra Mocidade sobre as Tendências da Poesia Modernista no Brasil, só citei dois poemas e um deles é o primeiro daqueles três que você me mandou, se lembra? Acho mesmo que você devia continuar essas impressões de agreste tão sugestivas e tão simples. Que acha você de dar a todas elas o nome genérico de Agreste? Ou fazer como eu com 
os meus 'Momentos' e 'Paisagens': 'Momento n. 1', 'Momento n. $2^{\text {' }}$, 'Paisagem n. $5^{\circ}$ ' e assim por diante (...) (MA, 12-III-1926, Id. Ibidem, p. 97).

Além desse diálogo sobre os três poemas e o livro de poesias lançado no "inferno da biblioteca", vemos na correspondência que Mário solicitou insistentemente a Cascudo colaboração para a revista Terra roxa e outras terras. A primeira solicitação foi provavelmente a que está na carta de três de fevereiro de 1926: "Quanto a Terra Roxa embora o $1^{\circ} \mathrm{n}$. tenha saído fraco a nosso ver, tem causado algum barulho. Você me mande qualquer coisa pra ela sem no entanto exceder no tamanho" (MA, 3-II-1926, Ib. Idem, p. 87). Após alguns meses, não recebendo colaboração alguma do amigo, Mário escolheu, entre os manuscritos que recebera dele, o poema que mais lhe agradara, "Não gosto de sertão verde" 73 e, à revelia do amigo e não cumprindo com sua palavra ${ }^{74}$, encaminhou-o aos editores da revista paulistana, apenas avisando Cascudo após o envio (MACHADO, 2012, p. 30):

\begin{abstract}
sim: recebi carta versos revistas, recebi e li tudo, adorei tanto o 'Não gosto de sertão verde' que roubei ele por minha conta e já que você não quis mandar nada pra Terra Roxa dei o poema pros redatores que por sinal se entusiasmaram também. Aconselho apenas o escrever aquelas palavras 'escorre lento' e a outra que não me lembro agora, naturalmente em horizontal. Essas ideografias na verdade são falsas e também caí nelas e errei. Na verdade não dizem nada mais que o que a imaginação do leitor inteligente bota de si no poema (...) (MA, 22VII-1926, apud, CASCUDO, 2010a, p. 113).
\end{abstract}

\footnotetext{
${ }^{73}$ Cf. (...) "Pra breve mando dois ou três poemas pra V. deliberar e rir. Por enquanto mando os nomes; 'Feitiço' e 'Não gosto de sertão verde'. Este dedicado ao poeta Manuel Bandeira, meu mata-borrão lírico” (...). (CC, 18-V-1926, apud, CASCUDO, 2010a, p. 105). Só na carta de vinte e cinco de maio de 1926 que o segundo poema seria apresentado a Mário (Cf. CC, 20-5-1926, Id. Ibidem, p. 107). Não há registros sobre o poema "Feitiço". Talvez nunca tenha sido publicado (GALVÃO, 2012, p. 24).

${ }^{74}$ Em vinte e um de abril de 1926, Mário volta a recorrer nos assuntos referentes à contribuição de Cascudo em Terra Roxa e sobre os poemas outrora apresentados, mencionando a utilização do primeiro deles em artigo que desenvolveu sobre a poesia modernista (já mencionado no corpo do texto); insistiu que Cascudo continuasse a escrever poesias e manda-las para que ele analisasse, garantindo que não publicaria nada sem a sua autorização: (...) "Você afinal inda não me mandou nada pra Terra Roxa. Mande pedaço de livro se não quiser escrever artigo porém faço questão de ver você em Terra Roxa camaradando comigo. Citei um dos poemas de você num artigo sobre Tendências da Poesia Modernista Brasileira que deverá sair em Mocidade. Quando sair mando. E repito o ultimatum: você está na obrigação de continuar a escrever versos e se não quiser, está duma ou doutra maneira na obrigação de mandar ou originais ou cópias dos versos que já tem feitos. Dou minha palavra que nada publicarei sem licença de você. É pra meu gozo pessoal (MA, 21-IV-1926, Id. Ibidem, p. 100).
} 
Em comentário a "Não gosto de sertão verde", José Luiz Ferreira (2010) relaciona-o, contudo à grande atração que o autor tinha pela cultura sertaneja, fato comprovado na divisão do sertão desse poema em dois polos, sendo que aquele que caracteriza o sertão com toda sua aspereza e adversidade é o que predomina, mesmo que atestando a existência de um outro sertão que, de certa forma, ameniza o clima de adversidade referido, como demonstra Ferreira (FERREIRA, 2010, p. 136; GALVÃO, 2012, p. 20):

É curiosa essa opção do poeta, uma vez que a grande alegria do sertanejo se dá justamente com a chegada do inverno, momento em que tudo se transforma e a vida renasce naquelas terras áridas. Contudo, a opção feita pelo poeta reforça a idéia de que a cultura sertaneja, constituída e mantida dentro das condições de adversidades, principalmente, do clima, que será o grande objeto de estudo e do desejo dele como 'autêntico' sertanejo. Essa perspectiva parece conceber que é diante do clima hostil daquela região que o homem sertanejo se constitui e se mantém nas suas tradições (FERREIRA, 2010, p. 136).

Segundo Dácio Galvão (2012), o poema "Não gosto de sertão verde" pertence a um conjunto de textos plenos de "brasilidade", produzidos na perspectiva estética de modernidade desencadeada àquela época. Para o autor, uma plêiade de escritores mais ligados a Mário de Andrade buscava uma arte literária de identidade própria que fosse ungida, entre outros aspectos, da complexidade etno-linguística formadora de uma textualidade identificada com o Brasil, pairando em inúmeras nuances contributivas advindas de escritas e falas das regiões do país. Afinado com o que se produzia de mais avançado em termos de pensamento e de matéria prima poética, Câmara Cascudo anexava, não à toa, seus poemas em cartas endereçadas aos protagonistas ou a alguns dos principais formuladores do Modernismo de então, entre os quais estariam os nomes de Ascenso Ferreira, Mário de Andrade, Manuel Bandeira, Carlos Drummond de Andrade, Ribeiro Couto e Joaquim Inojosa.

A diagramação do poema "Não gosto de sertão verde" na revista Terra Roxa e outras terras é diferenciada, atendendo em destacado espaço da página aos apelos formais propostos por Cascudo. Entretanto, o formato do poema na revista não corresponde exatamente à composição na versão caligráfica remetida para Mário em 
vinte e cinco de maio de 1926. Mário, embora tenha gostado tanto do poema que tomou a liberdade de publica-lo sem combinar com o autor, deixou a diagramação final por conta dos editores responsáveis (GALVÃO, 2012, p. 21-22). Atitude que não foi apreciada por Cascudo, que ficou com suas emoções oscilando entre a cólera e o agradecimento, com a publicação de versos que, em sua opinião, foram feitos para serem guardados ou esquecidos; discordando Mário, expôs as prerrogativas de sua produção:

V. é um grande traidor. Versos como aqueles não se publicam, seu Mário, guardam-se ou esquecem-se. Estou oscilando entre a cólera e o agradecimento. Vou explicar porque escrevo certas palavras em letras espaçadas e obíquas. Por ideografia pictorial (?!) V. continua a esperar a colaboração do leitor ao jeito de Baudelaire e Conrad? Eu, dentro do possível, tendo despertá-lo por uma visão gráfica, uma sigla que o ajuda na associação das ideias a pensar no objeto descrito. Devagar, lento e escorre escritos desta maneira traduzem o tema numa expressão quase sensível. V. não tem feito outra coisa com o seu estilo tamanduá-bandeira senão 'obrigar' o leitor a 'ver' menos do que concorda (que é uma questão secundária) (CC, 8-VIII-1926, apud, CASCUDO, 2010a, p. 116).

\subsubsection{A correspondência como espaço de sociabilização com outros poetas ${ }^{75}$ : Manuel} Bandeira, Ascenso Ferreira e a vanguarda argentina

No contexto da rejeição ao experimentalismo de "Não gosto de sertão verde" e como autor de poemas ideográficos "São Pedro" (Klaxon, n. 4, 15 de ago. 1922) e "Momento" (A Idea Ilustrada, abr. 1925), Mário de Andrade perguntava e se expressava

\footnotetext{
${ }^{75}$ Gostaríamos de esclarecer que deixamos a referência feita ao poeta Jorge Fernandes de fora dos aspectos analisados nesta secção por já termos feito citação sobre o mesmo, no corpo da correspondência de Cascudo e Mário em notas do capítulo anterior (Cf. nota 36). Entretanto, deixamos aqui ainda registrado, que é possível, por exemplo, acompanhar aspectos que giram em torno da editoração do Livro de Poemas, única obra do poeta potiguar. A primeira menção, diz respeito ao incentivo de Câmara Cascudo para que Jorge inicie o processo de publicação da obra (Cf. CC, 17-IV-1926, Id. Ibidem, p. 128), a segunda seria a cobrança que Mário fará para que Jorge entregasse o projeto do livro, quando de sua primeira viagem ao Nordeste (Cf. MA, 30-IV-1927, Id. Ibidem, p. 130). Na terceira, Mário volta a cobrar o envio dos versos (Cf. MA, 29-IX-1927, Id. Ibidem, p. 136); na quarta referência, Cascudo notícia a conclusão do livro (Cf. CC, 1-I-1928, Id. Ibidem, p. 139). Na quinta, Mário cobra a Cascudo ao menos o índice, pois Jorge demorava a retornar suas cartas (Cf. MA, 22-I-1928, Id. Ibidem, p. 141-142). Na sexta e última alusão, Cascudo confirma a publicação, embora reclame da qualidade editorial, esperava dar-lhe melhor feição em outra oportunidade (Cf. CC, 2-II-1928, Id. Ibidem, p. 143). Uma segunda edição do livro de poemas só veio a ser produzida sob a supervisão de Veríssimo de Melo em meados dos anos de 1970. Para maior conhecimento dos fatos em torno da respectiva obra, ver: (ARAÚJO, 1995).
} 
no deleite pela leitura do poema "Não gosto de sertão verde"; em carta remetida em 22 de julho de 1926 a outro poeta não menos fora de instigações experimentais vanguardistas na juventude e na maturidade, seu grande amigo Manuel Bandeira ${ }^{76}$ (GALVÃO, 2012, p. 38):

\begin{abstract}
Quando vai pro Norte? Mande contar e mande dizer o que achou do poema do Luís da Câmara Cascudo dedicado a você. Acho aquilo uma maravilha. Se você for pro Norte e passar em Natal quero que fique amigo dele. É batuta e meu amigo de verdade (MA, 24-VII-1926, apud, MORAES, 2001, p. 300).
\end{abstract}

Dias depois, Manuel Bandeira indagaria a Mário: “(...) qual é o endereço do Luís da C. Cascudo? Quero oferecer meu livro a ele. Li o poema de Terra Roxa e gostei muito" (MB, 25-VIII-1926, apud, MORAES, 2001, p. 304). Quando da visita que fez a Câmara Cascudo em Natal, durante 1927, Manuel Bandeira falou das impressões que teve de Cascudo e de sua poesia:

\begin{abstract}
Jantei com Cascudo (Recebeu os seus livros). Cascudo... é engraçado. Falador, reclamista, chamador de atenção: de repente a gente faz uma pilhéria muito besta e ele cai numa gargalhada de menino tão boa, tão ingênua, que reconcilia a gente $\operatorname{logo}{ }^{77}$. Está bancando o historiador, que poeta nada! Não insulte! Vi uns poemas dele. Tenho visto que está muito generalizado por demais os jogos verbais do Guilherme sobre gostosas vozes negras e índias. Fica bonito mas está tudo muito parecido (MB, 5-III-1927, apud, MORAES, 2001, p. 338)
\end{abstract}

Nestas cartas trocadas entre Mário e Manuel Bandeira, vemos que o autor de Losango Caqui, enfatiza o alcance coletivo da amizade voltado para o exercício da sociabilidade. Ao tomar a correspondência como espaço de expressão de sentimentos, conformando afetos e identidades, alertando-nos para uma abertura que ela

\footnotetext{
${ }^{76}$ Em carta de dezenove de março de 1926, Mário faz referência aos planos de viagem para dezembro do respectivo ano pelo Nordeste e dos planos de conhecer pessoalmente Câmara Cascudo: (...) "Pois é, estou com viagem marcada pro Norte. Vou na Bahia, Recife e Rio Grande do Norte onde vive um amigo de coração que no entanto nunca vi pessoalmente, o Luís da Câmara Cascudo. É um temperamento estupendo de sujeito, inteligência vivíssima e inda por cima um coração de ouro brasileiro. Gosto dele" (MA, 19-III-1926, apud, MORAES, 2001, p. 278). O objetivo não se concretizou à época, só vindo a acontecer em sete de agosto de 1927 (Cf. ANDRADE, 1983, p. 191).

${ }^{77}$ Ao que se ver Cascudo também teve uma boa impressão de Manuel Bandeira: (...) "Já lhe falei do Manuel Bandeira em Natal? (...) Gostei imensamente dele e V. foi um assunto saboreado devagar" (...). (CC, 28-III-1927, apud, CASCUDO, 2010a, p. 125).
} 
possibilitava: sensibilidade para a reflexão artística. Para Velloso (2009), Mário entendia que o afeto pelos companheiros de vida deveria extrapolar o nível restrito das relações pessoais, induzindo ao processo reflexivo (VELLOSO, 2009, p. 206).

A articulação entre intelectuais e artistas, que Mário de Andrade praticou por intermédio da produção epistolar, em dimensão nacional, fazendo circular ideias, informações, ponto de vista teórico, produção literária, articulou Câmara Cascudo com a produção modernista do eixo Rio - São Paulo - Minas, fazendo circular informações preciosas para o caráter nacionalista do movimento, enquanto ampliava o espaço de atuação de Câmara Cascudo no campo intelectual, aumentando a rede de simpatizantes dos seus projetos. Para isso Mário de Andrade valia-se da autoridade que havia conquistado e da livre circulação que possuía nos periódicos modernistas.

Cabe recuperar outro evento que evidencia bem as ações de Mário de Andrade na tentativa de consolidar o Movimento Modernista por meio de diálogos epistolares; trata-se dos textos publicados no "Mês modernista". Foi-lhe solicitada, pelo jornal $A$ Noite, a indicação de cinco nomes que colaborassem com artigos para essa seção que teria duração de um mês. Os escolhidos foram Carlos Drummond de Andrade, Sérgio Milliet, Manuel Bandeira, Martins de Almeida e Prudente de Morais Neto, além dele próprio. Verifica-se, principalmente, a preocupação que teve em combinar escritores experientes com iniciantes, todos, evidentemente, afinados com suas perspectivas teóricas (MACHADO, 2012, p. 238). Pensou em convidar Cascudo para esse projeto, mas o fato dele morar em Natal inviabilizaria o trabalho conjunto, caso ocorresse algum atraso:

\footnotetext{
Mando aqui pra você ler dois artigos meus saídos o a-máquina num jornal do Paraná e o outro n'A Noite, do Rio de Janeiro. Lhes dou alguma importância na evolução do meu modo de pensar, por isso que mando. Mande opinião. A Noite, do Rio, organizou uma coisa engraçada: um Mês Modernista, cada dia um artiguete de meia coluna assinado por um modernista. Seis modernistas, um pra cada dia da semana, repetido quatro vezes. Pensei em você porém a coisa foi organizada com afobação e você mora tão longe! Está saindo gostoso. Os colaboradores somos: Manuel Bandeira e Prudente de Moraes Neto (Rio) Martins Almeida e Carlos Drummond (Minas) Sérgio Milliet e eu (S. Paulo). (...) Antes do Mês saiu a minha entrevista com esse cabeçalho horrível me dando chefia do Modernismo, contra o que
} 
protestei em carta publicada no mesmo jornal (...) (MA, 1-I-1926, apud, CASCUDO, 2010a, p. 85-86).

Cascudo também ligou Mário a suas redes de sociabilidade. No Nordeste, vemos que autor de Joio, intermediou sua relação com o poeta Ascenso Ferreira. Além de fazer com que a obra de Mário se tornasse conhecida pelos escritores da vanguarda argentina. Aqui, percebe-se que a amizade estabelece rede de influências, inventa lugares de convivência, laços de resistência, conseguindo ampliar oportunidades de encontros e interações sociais, conforme nos lembra Mônica Velloso (VELLOSO, 2009, p. 208).

Ascenso Ferreira foi apresentado por Cascudo a Mário em carta de vinte e quatro de setembro de 1926. Nesta carta, o crítico potiguar elaborou breve menção de seu perfil biobibliográfico e fez questão de intermediar a relação porque Ascenso conhecia bem o sertão e suas coisas, especialmente o pernambucano, embora este possuísse na concepção de Cascudo a "desvirtude" de uma influência estrangeira mais intensa que o potiguar. Ascenso queria ser amigo de Mário, embora teimasse continuar admirador:

Apresento a V. o Ascenso Ferreira, poeta e velho camarada meu. Encontrei-o em 1924 soneteando imperturbável e lindamente. Ascenso é do tamanho dum bonde da Light e com um'alma maior que o Capibaribe. São, forte, bom, inatual pelo caráter, moderno pela sensibilidade. Nome do ex-livro - Rosas de Cinzas. Nome do livro no prelo - Catimbó. Deduza. Ascenso conhece bem o sertão. O sertão de Pernambuco possui a desvirtude de uma influência estrangeira mais intensa que o meu. Ascenso quer ser seu amigo porque está teimando em continuar admirador. Mando versos do Ascenso. Endereço Tesouro do Estado - Recife. Pernambuco (CC, 24-VII-1926, apud, CASCUDO, 2010a, p. 120) ${ }^{78}$.

\footnotetext{
${ }^{78}$ As cartas do autor de Macunaíma para Ascenso Ferreira podem ser acessadas por intermédio do terceiro volume do Movimento Modernista em Pernambuco de Joaquim Inojosa (1969), trata-se da reunião de dezessete cartas de Ascenso e de sua esposa Stella Griz Ferreira. Em nota, o autor, afirmou que as cartas foram entregues por Edgard Cavalheiro, quando ainda vivo. Entretanto, o crítico asseverou que em uma de suas últimas entrevistas realizadas com Ascenso, ele teria demonstrado interesse em divulgalas, dando a sua esposa Stella um documento que o autorizava (INOJOSA, 1969, v. 3, p. 334, nota 75). Na primeira carta de Mário para Ascenso, vemos o agradecimento pelos versos enviados e o entusiasmo de saber um pouco mais sobre a sua poesia: "Você de certo já sabe pelo Luís [da Câmara Cascudo] porque não respondi logo agradecendo os versos que me mandou. (...) não quero esperar mais tempo pra dizer pra você como fiquei contente com os versos que me mandou. São simplesmente estupendos, muito caráter, muita força expressiva uma expressão que não podia ser de ninguém neste mundo senão de brasileiro. (...) Tudo méritos excepcionais que me dão curiosidade doendo de conhecer o livro todo. Não se esqueça de o mandar pra mim assim que sair" (...). (MA, 2-XI-1926, apud, INOJOSA, 1969, v.3, p. $335)$.
} 
Em Belém, Mário escreve uma carta no dia dezenove de maio de 1927, durante a viagem da comitiva encabeçada pela Sra. Olívia Guedes Penteado; nela, o quase Macunaíma comenta suas impressões ao desembarcar no Recife, de seu encontro com Inojosa e Ascenso e de como ficou "jururu feito um socó” de não ter encontrado o amigo Cascudo em nenhum lugar:

Andei assuntando mares, portos e ruas desde Recife, com esperança de enxergar você num automóvel, num cais, numa lancha, num barcoveleiro azul e mesmo nalguma jangadinha. (...) No Recife até pouco estive com o Inojosa amando. Quem conheci mesmo gozado foi o Ascenso, que bichão querido não? Agora só falta você. (...) (MA, 19V-1927, Id. Ibidem, p. 132).

Como se vê, Cascudo obteve êxito em estreitar os laços de amizade entre Mário e Ascenso. Em carta de janeiro de 1928, Mário comenta sobre a visita de Ascenso a São Paulo em sua casa na rua Lopes Chaves; reclama com Cascudo por ainda não ter feito o mesmo, expondo que embora não tivesse prefeito pra expor as coisas da terra, tinha sua prefeitura de amizade, que garantiria muita diversão:

Quanto ao Ascenso esteve aqui, matamos saudades bem. Agora falta você me visitar no meu rincão. Infelizmente não tenho prefeito pra mostrar as coisas da terra pra você porém tenho eu em minha prefeitura de amizade com gordura e que a gente diverte isso garanto que divertirá (...). (MA, 22-I, 1928, apud, CASCUDO, 2010a, p. 142).

É nesse panorama literário que se iniciará a amizade epistolar, de quase duas décadas (1926-1944), entre Mário e Ascenso. Amizade iniciada, como pudemos ver, através de Luís da Câmara Cascudo. Além de ser aqui comprovado, esse fato figura tanto na correspondência travada entre Mário e Câmara Cascudo, quanto em depoimento concedido pelo autor de Catimbó a Edgard Cavalheiro em Testamento de uma geração: “(...) a quem muito devo é Luís da Câmara Cascudo. Foi ele quem me aproximou de Mário de Andrade e Manuel Bandeira" (FERREIRA, 1944, p. 84). Em uma carta de vinte e nove de março de 1960, Ascenso confessa a Veríssimo de Melo que caso o amigo passasse "uma vista na obra dos grandes poetas do Brasil e verá como o velho Ascenso está vivinho lá dentro" e que por essas e outras, muito devia a Câmara Cascudo: 
Muito devo ao nosso Câmara Cascudo nesse sentido: 'Ascenso, cuidado com a turma de declaradores, bichão'. E eu tomei o conselho do mestre. Só amostras de vez em quando, mas o todo ficou guardado para meus livros. Só de 10 em 10 anos postos em circulação (AF, 26III-1960, apud, MELO, 1989b, p. 22).

Infelizmente, não conseguimos encontrar no acervo do Ludovicus - Instituto Câmara Cascudo cartas de Ascenso enviadas para Câmara Cascudo, embora certamente o tenha feito. Entretanto, além dos registros já apresentados, ainda é possível observar Cascudo, em Gente Viva (2010b), afirmar que:

Ainda estava namorando, timidamente, a Poesia que o faria famoso. Disse para nós, depois de laborioso exercício para acomodar as duas pernas de colosso de Rodes, os poemas inesperados, estranhos, perturbadores, admiráveis pela novidade que vivia na alma do Povo. São os poemas do Catimbó (1927). Essas tertúlias, ou melhor, simpósios, porque eram mastigados e deglutidos, foram a caixa de ressonância (...).

Mantivemos amizade serena e profunda até hoje, porque a Morte não me separa dos amigos. A Vida sim. Faleceu no Hospital do Centenário, no recife, 5 de maio de 1965. Quatro dias depois teria 70 anos. (...)

Oferecendo-me Catimbó, escreveu em 1927: 'Cascudo. O título foi teu. Tome, portanto, o resto que te oferece, com todo gosto, o Ascenso Ferreira'. Seria pela solidariedade emocional com que o acompanhará (...) (CASCUDO, 2010b, p. 102-103).

No livro Mário de Andrade e a Argentina: um país e sua produção cultural como espaço de reflexão, Patrícia Artundo (2004) faz referência à atitude de Câmara Cascudo como intermediador entre Mário e os escritores argentinos Luiz Emilio Soto e Vignale. Em trecho do livro, Artundo afirma:

No que concerne ao Brasil e, particularmente, ao encontro de Mário com Soto e Vignale, os contatos iniciais foram estabelecidos em 1925 por meio de Luis da Câmara Cascudo, que atuou como intermediário entre uns e outros como se infere de sua correspondência com Andrade. Ele mesmo interessado em divulgar os autores argentinos 
como demonstrou em Joio (1924), já em 1923 a revista argentina Inicial havia publicado sua "Ronda de Muerte". (ARTUNDO, 2004, p. 64)

Embora desconheçamos de que maneira Câmara Cascudo se relacionou com os jovens argentinos, essa amizade parece ter sido muito estreita. Ainda segundo a autora, Câmara Cascudo

(...) não só remeteu ao escritor paulista um exemplar de Versos de la calle (1924) de Álvaro Yunque, mas, além disso, fez chegar a Soto o de A escrava que não é Isaura (1925). Esse envio propiciou o único artigo de relevância dedicado a Andrade durante os anos de 1920 na Argentina - intitulado "Las nuevas Corrientes Estéticas em el Brasil: Um Importante Libro de Mário de Andrade” -, publicado por Soto em Renovación (1923-1930), a importante revista fundada por José Ingenieros, Aníbal Ponce e Gabriel Moreau. (ARTUNDO, 2004, p. 64).

O livro de Álvaro Yunque foi remetido a Mário de Andrade junto com uma carta, datada de dez de junho de 1925, que expressava a opinião de Câmara Cascudo a seu respeito:

\footnotetext{
Mando um exemplar do livro de Yunque Versos de la Calle. Perdoe o papel. É a $2^{\text {a }}$ edição de 5 milheiros. E do ano passado. Esperando este livro demorei tanto a escrever-lhe que mereci um puxão d'orelhas. Yunque possui aquele "essencial expressivo" que V. encontrou em João Miramar. Para Luiz E. Soto, Yunque é o sentido poético da cidade moderna. Melhor V. julgará. É o livro que expressa uma nova orientação mental n'Argentina d'agora. Verso da rua com tinta segura e sem nuança. É o tema solitário. E a propósito do tema - receba o "Shimmy" que segue junto a esta carta (CC, 10-VI-1925, apud, CASCUDO, 2010a, p. 44).
}

Numa carta de doze de julho de 1925, Cascudo volta a falar de Luiz E. Soto, mas para pedir a Mário que enviasse um exemplar de A Escrava que não é Isaura para presentear aquele escritor e um outro amigo colombiano: 
Creio que lhe enviei versos. E que versos!...E um livro argentino, pedindo, em troca, outro Escrava para um meu camarada argentino que nasceu na Colômbia e Luís Emílio Soto, em tudo digno de nossa admiração e carinho (CC, 12-VII-1925, Id. Ibidem, p. 51).

Ainda em nove de dezembro de 1925, Cascudo escreveria a Mário informando do entusiasmo causado em Soto pela leitura da Escrava, comunicando que mandara o seu endereço para que o escritor argentino-colombiano enviasse um artigo que havia escrito sobre o livro: “O argentino-colombiano Luís Emilio Soto leu o Escrava duas vezes e está suando de entusiasmo. Mandei seu endereço para que enviasse a crônica a respeito do livro" (CC, 9-XII-1925, Id. Ibidem, p. 80) ${ }^{79}$.

Mário escreveu no dia três de fevereiro de 1926, quando informou ao amigo potiguar sobre a visita que recebeu de Soto, como das impressões que lhe causou o encontro:

Tenho estado com o Luís Soto aqui vindo pra ver as coisas. Rapaz sério de voz cortante que bate na gente e dói. Espírito combativo muito construído. Me pareceu um pouco cheio desse bolchevismo idealista que a mocidade inventa pra poder amar ou atacar as coisas. (...) Já estive com ele duas vezes e uma delas muito tempo umas quatro horas aqui em casa. Trouxe um amigo muito inteligente e vivo, um tal Vignale, conhece? Passei onde eles estão hospedados mas não os encontrei. Reparei que são rapazes mais ou menos pobres e se vexaram de me contar onde estavam. Talvez mais os tenha assustados a minha sala de estudos que parece de gente rica, cheia de quadros e livros luxuosos. Mal sabem eles que tudo isso ou é dado ou adquirido com sacrifício imenso. Também tive a impressão que estavam desapontados com o Modernismo brasileiro. Julgaram naturalmente encontrar uma coisa e encontraram outra. Com esta minha franqueza imediata lhes disse logo o que pensava do universalismo idealista em que estão. E qual a razão por que devemos nos esforçar cada qual em ser nacional no seu país (...) (MA, 3-II-1926, Id. Ibidem, p. 89-90).

\footnotetext{
${ }^{79}$ Mário agradecerá posteriormente a iniciativa do amigo Cascudo em carta enviada em meados de janeiro de 1926: (...) "Porém antes que me esqueça te conto que recebi anteontem uma carta gentilíssima do Soto com um artigo sobre a Escrava saído em Renovación. Deus lhe pague o que você vem fazendo por mim. Vou esperar uns cinco ou seis dias pra responder pro Soto, porque assim posso mandar pra ele o meu livro novo que está sai-não-sai”. (...) (MA, I-1926, apud, CASCUDO, 2010a, p. 84).
} 
Em carta de doze de março de 1926, Mário volta a falar em Luís Soto, de sua viagem de retorno para a Argentina, confessa que tinha gostado do amigo platino, mas não compreendia seu ar misterioso, meio bolchevista; comenta que tinha ganhado oito livros modernos do amigo, mas não se entusiasmou muito, pois, se "o Modernismo argentino é isso o nosso é bem mais forte":

O Luis Emilio Soto foi-se embora. Gostei dele de verdade. Um pouco misterioso. De repente desaparecia. Esteve mais de mês em S. Paulo desconfio um poucadinho que veio em alguma missão que não sei o que é. Possivelmente bolchevista... Não sei e não quero fazer mau juízo de ninguém. Peço mesmo pra você que ignore isto que estou falando porque pode ser falso. Em todo caso é bem esquisito isso de virem dois homens da Argentina, passarem por literatos e desaparecerem de vez em quando dos meios literários, andarem ninguém sabia adonde, passarem um mês inteirinho em S. Paulo, não irem pro Rio (pelo menos pelo que contaram) só o Soto na véspera da partida pra Buenos Aires foi passar dois dias no Rio que no entanto como Brasil e como meio literário é mais importante que S. Paulo. Só disso que não gostei muito. No resto boa gente divertida inteligente e bastante livre. Me deram uns oito livros argentinos modernos que por sinal não puderam me interessar muito não. Se o Modernismo argentino é isso o nosso é bem mais forte. (...) (MA, 12-III-1926, Id. Ibidem, p. 97-98).

Além destes aspectos presentes na respectiva correspondência, esta relação do contato de Câmara Cascudo com escritores estrangeiros ao longo dos anos de 1920 é um fato atestado pelo próprio autor em seu livro Joio: páginas de literatura e crítica (1924), ao dedicar um capítulo inteiro às obras e autores argentinos, intitulado "Argentina Intellectual" 80 (CASCUDO, 1991b, p. 132-176). No texto que trata da obra de Moises Kantor, um dos grandes representantes do teatro moderno na Argentina, Cascudo (1924b) confirma esse contato mais estrito com o estrangeiro: "Botticelli vive su conflicto, no lo piensa', dizia-me em carta Moises Kantor” (Id. Ibidem, p. 137). Neste capítulo, além de Kantor, Cascudo discute aspectos da produção literária de mais nove escritores argentinos: Banjamim de Garay, Santos Vega, Fernan Felix de Amador, Hugo Wast, Froylan Turcios, Salvador Alfredo Gomis, Ricardo Gutierrez, Horácio

\footnotetext{
${ }^{80}$ Ao estabelecer crítica e comentário sobre Joio, Mário confessará a Cascudo que: (...) “A parte sobre a Argentina já é melhor. A mim, foi útil”. (...) (MA, 26-IX-1924, apud, CASCUDO, 2010a, p. 37-38).
} 
Quiroga e Arturo Capdevila. A escolha dos escritores é justificada pelo próprio autor, quando diz: "Escolhi os escriptores pela sua intensidade transmissora, nunca julgando a exuberância descriptiva e arroubo dialético o verdadeiro merecimento. Sente-se perfeitamente a impressão mental e observada". (CASCUDO, 1991b, p.151; MEDEIROS, 2012, p. 92).

Ao longo de todo o capítulo, o escritor dá evidências desse contato, ao discorrer com precisão e crítica sobre os intelectuais platinos. De acordo com Ferreira (2008), a partir da constatação de dez textos que tratam do tema no material levantado em sua pesquisa, a divulgação de poetas e escritores estrangeiros se prolongará ao longo de todo o ano de 1924 e a Argentina aparece como sendo o país com maior número de poetas e intelectuais por ele abordados (FERREIRA, 2008, p. 80; MEDEIROS, 2012, p. 89).

Nesse sentido, Joio reflete um aspecto fundamental das reflexões literárias de Câmara Cascudo: a necessidade de romper com as fronteiras geográficas e linguísticas do Brasil para estabelecer um diálogo mais eficiente com os demais países da América Latina. Essa necessidade é atestada logo no início do capítulo, quando faz referência a Banjamin de Garay (MEDEIROS, 2012, p. 92), dizendo que o mesmo

\footnotetext{
affirma e define a superioridade de sua cultura, ligando pelos seus artistas e pensadores, a mentalidade da América Latina. Alicercia o porvenir dos povos fraternos, indicando no mesmo potencial anímico a solida realidade das litteraturas communs.

(...)

Elle próprio, poeta e jornalista, sente a afinidade entre os latinos da América. (CASCUDO, 1991b, p. 134).
}

Ao mesmo tempo em que trata da Argentina intelectual, Câmara Cascudo relaciona-a com o continente, evocando também um Brasil intelectual. A exemplo dessa comparação, no texto que trata de Santos Vega, Câmara Cascudo afirma que "não há na literatura brasileira um movimento de carinho em derredor de um nome como os argentinos a Santos Vega.” (Id. Ibidem, p. 140).

Cascudo também revela através de suas leituras dos artistas platinos o espírito dialético do localismo e cosmopolitismo que se encontra na literatura vizinha. Ao discutir a obra de Hugo Wast, ele menciona: “'Flor de Durazno', 'Casa de los Cuervos' e 'Ciudad Turbulenta' synthetisam a obra de Hugo Wast. E' a alma argentina 
desvendada em seu tríplice aspecto de amor, guerra e desejo, de campo, villa e cidade".(Id. Ibidem, p.158).

Ainda que não exista uma pesquisa mais detalhada do contato de Cascudo com os artistas e intelectuais argentinos, alguns estudos, como os de Artundo (2004), Ferreira (2008) e Medeiros (2012), assim como as correspondências pessoais do escritor trocadas com Mário de Andrade, Joaquim Inojosa e Monteiro Lobato durante a década de 1920, apontam um intenso contato entre ele e os escritores daquela nacionalidade (MEDEIROS, 2012, p. 93).

Com efeito, conforme sugeriu Gabriela Pellegrino Soares (2006), vemos que ao longo da primeira metade do século $\mathrm{XX}$, é possível ver nascer, em diferentes movimentos, a percepção de que a América - Espanhola, para uns, para outros Latina, ao envolver o Brasil - estava apta a desenvolver seus próprios "meridianos intelectuais", podendo as nações que a integravam buscar inspiração e referência umas nas outras, e não apenas no Velho Mundo, cujo modelo foi por muito tempo tomado como única possibilidade de superação da "barbárie" local. Em lugar do olhar detrator, a nova percepção sugeria representações afirmativas sobre as sociedades latinoamericanas e aguçava o desejo de conhecimento mútuo. Pois, ao lado das aspirações identitárias, os países vizinhos Brasil e Argentina passavam, em certos contextos, a figurar como referências de desenvolvimento e concepções de modernidade que iam ao encontro das premências nacionais. Ao mesmo tempo, apresentavam-se como potenciais mercados de bens culturais a serem explorados (SOARES, 2006, p. 243).

\subsubsection{As obras e os projetos literários de Mário e Cascudo mencionados no corpo da correspondência}

Além da poesia e dos poetas nacionais e platinos tratados na correspondência de Cascudo e Mário, vemos que também houve espaço nesta epistolografia para a troca de obras, a comunicação dos projetos literários que chegaram a ser concluídos, ou os que apenas ficaram no campo do diálogo epistolar. Como sabemos, Cascudo foi o primeiro a encaminhar suas principais obras produzidas na década de vinte: Joio e Histórias que o tempo levam...:

Mando meus dois livros. O último Joio é a melhor parte que tenho realizado. O História é história. Publiquei em 1921 o Alma patrícia 
que João Ribeiro, Afrânio etc. elogiaram e o Osório escoicinhou lindamente. Homem oportuno (CC, 25-VIII-1924, apud, CASCUDO, 2010a, p. 34).

Na carta de vinte seis de setembro de 1924, Mário comenta sua impressão de Joio e Histórias que o tempo levam:

Dos livros: Joio assinzinho; as Histórias o tempo não levará. Acho desagradável essa mania de grudar crônicas em livro, Crônica é pra jornal. Livro é uma concepção mais inteiriça e completa. As Histórias são um livro. (...) Do seu Joio no entanto uma página me interessou vivamente: "Doutor João". Muito bem contado e caso interessantíssimo. (...) A parte sobre a Argentina já é melhor. A mim, foi útil. Quanto às Histórias que o tempo leva, livro interessantíssimo sob todos os aspectos. Gozei de princípio a fim. Excelente repositório de esclarecimentos. Utilíssimo. E sob o ponto de vista artístico boa realização. O que mais me atrai nos seus escritos deste livro, e mesmo do Joio Luís da Câmara Cascudo, é a sua despreocupação da literatura. Não há esse preconceito de fazer literatura que é a maior praga da arte de escrever. Nada de frases bem acabadinhas, ritmos preconcebidos, adjetivos para encantar; linguagem direta, pessoal, enérgica, simples, eficaz. Muito bem, Admiro seu livro (...) (MA, 26IX-1924, apud, CASCUDO, 2010a, p. 37-38).

Durante a década de vinte, veremos que por parte de Luís da Câmara Cascudo, foram mencionados na correspondência projetos editoriais que não se concretizaram, nos valendo do campo da crítica genética ${ }^{81}$; observamos a desestabilização da ideia de que Mário interferiu mais intensamente na produção intelectual de Cascudo, em especial

\footnotetext{
${ }^{81}$ De acordo com Marie Hélène Paret Passos (2014), os acervos de escritores são reservatórios memoriais por guardarem testemunhos de vida, tanto pessoais quanto literários, registrados em vários tipos de suportes materiais ou virtuais, geralmente constituídos por centenas de documentos heteróclitos que pertencem à esfera privada do escritor e que aparentemente não dizem respeito ao público leitor. Parte desse material, a que concerne aos "papéis", constitui-se em objeto de estudo da crítica genética, e, uma vez organizada, classificada e analisada, essa massa documental pode fornecer pistas interpretativas da obra analisada pelo pesquisador. Dentro desses diversos papéis, está, entre outros, a correspondência. No campo dos estudos literários, é patente o valor do estudo da correspondência dos escritores. Para a Crítica Literária, é um recurso fundamental no que concerne a pesquisas de fontes ou biográficas. No campo da Crítica Genética, cuja vocação é o estudo do processo criativo, embora, na maioria das vezes e dependendo de suas características, a carta não seja considerada como documento genético propriamente dito, é incontestável que ela pode trazer informações primordiais posto que tem um papel de testemunha e que, cedo ou tarde, poder-se-á encontrar seu conteúdo, ou parte dele, reciclado no texto de uma obra literária. Quando acontece, é um fato que pode modificar de forma radical, não somente a análise da obra em questão, mas também a leitura dessa mesma obra (PASSOS, 2014, p. 190-191).
} 
nas iniciativas em torno do folclore, que não se iniciaram a partir do ano de 1937, como fez crer Veríssimo de Melo. Em carta de vinte e um de maio de 1925, Cascudo informa ao amigo que "estava folclorizando" (CC, 21-V-1925, Id. Ibidem, p. 42), o que muito entusiasmara Mário, que comentaria no post scripitum da carta de vinte e seis de junho de 1925:

Gostei de saber que você (você = tu) está folclorizando. Isso mesmo. Trabalhe e mande as coisas que fizer. Me interessam formidavelmente porque são inteligentes, bem pensadas, ditas com leveza, graça. Só depois de tudo isso é que me interessam porque são suas, de amigo. Quando gosto, gosto primeiro pelo valor. Não misturo amizade com valor. (...) (MA, 26-VI-1925, Id. Ibidem, p. 50).

Há de se ter como exemplo o projeto de um livro que teria como título Crendices e Tradições, mencionado na carta de doze de julho de 1925. Nela, Cascudo afirmou que desde 1920 já vinha se dedicando sobre a temática do folclore e encaminhou o que viria a ser sumário da obra, explicando por seu intermédio a estrutura da mesma:

Mando incluso o índice do meu livreco. Desde 1920 que lia e reunia notas, viaja e observava. Vamos ver se o bicho viverá...

(...)

\section{Crendices e Tradições}

Tradições dos cultos esquecidos

$*$

A. Selenolatria sertaneja

B. Potamolatria sertaneja

C. Tradição do Fogo, do Sol e das Estrelas

Lendas

A. Lendas de origem indígena

B. “ “ “ portuguesa (europeia)

C. " " " " negra

D. “ “ formação brasileira (adaptação)

E. Lendas apologéticas e místicas

Parlendas e brincos infantis

Estórias tradicionais do sertão
A. Estórias de encantamento, de castigo e de astúcia
B. Estórias e tipos populares
C. Contos etiológicos
D. Moral e técnica das estórias sertanejas 
A. Licantropia sertaneja

B. Caipora, deus selvagem

Festas do ritual e da tradição

Como se vive no Sertão

Notas e adendos

Nota

Os títulos sublinhados são estudos da crendice coletivamente. As letras marcam os capítulos especiais. As crendices e tradições abrangem de Pernambuco ao Ceará, especialmente e caracteristicamente o meu Estado. Há muita novidade. O sinal * avisa os trabalhos terminados (CC, 12-VII-1925, id. Ibidem, p. 51-53).

Em carta de seis de setembro de 1925, Mário confirma o recebimento do índice acima e de dois outros ${ }^{82}$, embora se mostre mais interessado por este, que o deixou com "água no bico" por se aproximar de suas preocupações e assuntos, estimula o amigo a que desenvolva e os mande, mesmo não tendo autoridade e sabença em nenhum dos outros assuntos:

Recebi os índices. Também me puseram água no bico. Confesso que o livro sobre Lendas e tradições me interessa mais porque me afeta nos meus assuntos e preocupações mais que os outros. Porém que venham estes e os devorarei. Não tenho nenhuma autoridade nem sabença em nenhum dos assuntos pra dar parecer. Digo só que são interessantíssimos. Buda santo católico me parece francamente mais boutade que outra coisa. O nome do livro é ativismo faz cócega na gente Terá extração certa. O sobre López me ajudará na minha sabença de história pátria tão pouco aprofundada (MA, 6-IX-1925, Id. Ibidem, p. 63-64) ${ }^{83}$.

\footnotetext{
${ }^{82}$ Cf. (...) "Terminei, há seis dias, duas monografias. Uma Morte do Francisco Solano López é uma recolta de leituras, depoimentos e críticas, para o VIII Congresso Brasileiro de Geografia que, mercê de meu gênio, sou delegado aqui. A outra é Buda é Santo católico? Creio ser o primeiro a tratar deste assunto em idioma brasileiro e língua portuguesa (as colônias inclusive). Dei o meu depoimento completo, seguro e verídico. Da confissão resta V. abençoar a boa vontade, e com licença da palavra, o desejo de ser gente..." Cf. (CC, 12-VII-1925, Id. Ibidem, p. 52). Cascudo voltará a esse mesmo assunto em carta de vinte e três de agosto de 1925, quando manda os sumários: "Fechei a carta deixando o discurso fora. Não querendo romper o envelope preferi fazer outras linhas. Mando os índices das monografiazinhas que, dentro em breve V. receberá. (...) Mande a sua impressão do cardápio enviado pela minha desocupação à sua complacência". (CC, 23-VIII-1925, Id. Ibidem, p. 58).

${ }^{83}$ Sobre este último, vemos Mário Informar que escreveu a seu respeito em sua coluna "Livros e Livrinhos": "Escrevinhei uma nota besta sobre o livro de você. Também praquê que você foi escrever
} 
Ainda sobre a temática do folclore e das coisas do sertão potiguar, vemos a manifestação de Câmara Cascudo sobre os efeitos do progresso neste espaço da tradição e da memória que irá se repetir em obras como Vaqueiros e Cantadores (2005c) e Viajando o sertão (1992), vejamos os fragmentos:

O sertão está morrendo engolido pelos açudes, pisado pelo Ford, cego pela lâmpada elétrica. A menina qu'eu vi reparando na gente pela fricha da porta, vive na capital, usa sapatinho vermelho e está ensinando shimmy às primas da fazenda.

A casa grande derribou-se. Agora inaugura-se o estilo bolo de noiva com requififes e penduricalhos nas paredes. Vaqueiros? Sumiram-se Estamos comprando zebu, caracu, hereford etc. Bicho de comer em cocho e beber parado. Não sabe ouvir aboio nem corre no fechado da caatinga. Morre a vaquejada e com ela duzentos anos de alegria despreocupada e afoita. (...) (CC, 26-VI-1926, Id. Ibidem, p. 111).

A transformação é sensível e diária. As estradas de rodagem aproximaram o sertão do agreste. Anulando a distância, misturaram os ambientes. Hoje a luz elétrica, o auto, o rádio, as bebidas geladas, o cinema, os jornais, estão em toda parte. Os plantadores de algodão vêm vender os fardos nas capitais. Os filhos se educam nos colégios distantes. Tudo perto pelo auto. (...) (CASCUDO, 2005c, p. 12).

O sertão perdeu seus cantadores. A vida transformou-se. As rodovias levam facilmente as charangas dum para outro povoado. As vitrolas clangoram os foxs de Donalson e de Youmans. As meninas, que conheci espiando os 'home' por trás das frixas das portas, reclusas nas camarinhas dançando a meia légua de distância do par, hoje usam o cabelinho cortado, a boca em bico-de-lacre, o mesmo palavreado das tango-girls do Aéreo Clube e Natal Club. Numa viagem em janeiro de 1928, eu mostrava a Mário de Andrade, nos arruados do baixo-Açu, crianças com a bochechinha pintada de papel encarnado, fingindo

história? É coisa que sei como brasileiro honesto só, não sei a fundo e me limitei a dar a notícia” (...) (MA, 26-X-1927, Id. Ibidem, p. 137). Com relação ao primeiro livro anunciado nesta passagem, vemos Cascudo tecer as seguintes considerações ao amigo: (...) "Já lhe disse que o Bispo de Natal pediu-me que não publique o Buda é Santo Católico? Pois é. Resta o Solano López. Vai breve”. (...) (CC, 25-maio de 1926, Id. Ibidem, p. 106). Em carta de primeiro de janeiro de 1928, Cascudo agradece a nota redigida por Mário a respeito de seu livro sobre Solano López: (...) "Muito obrigado. O registro parece, com licença da palavra, programa de cinema. Lê-se esperando 'ver' depois o resto. E o resto não chega". (...) (CC, 1-I1928, Id. Ibidem, p. 139). 
rouge. Encontrei jornais do Rio e S. Paulo em toda parte. O sertão descaracteriza-se. É natural que o cantador vá morrendo também (CASCUDO, 1992, p. 46).

Nas passagens que aqui selecionamos, podemos ver que o sertão era o lugar onde o progresso, durante muito tempo, não havia chegado, e por isso mesmo era o repositório da alma nacional, o lugar da autêntica cultura regional e das tradições. $\mathrm{O}$ litoral cosmopolita, estrangeirado, embora tivesse, em outras épocas, representado a vida aristocrática e senhorial como no tempo dos holandeses, que tanto admirava, agora se via descaracterizado pela vida moderna, degradado pela vida burguesa do dever e do haver (ALBUQUERQUE JR, 2013c, p.114).

Nesta perspectiva, a correspondência entre Mário e Cascudo permite a concretização mais cabal dos "arquivos da criação", termo pertencente ao campo da crítica genética, que, nos estudos literários, interessa-se por compreender os caminhos da produção artística. Os "arquivos da criação" constituem um dos veios mais ricos no estudo da epistolografia. José-Luiz Diaz circunscreve a ampla gama de possibilidades de exploração da escritura cronística-testemunhal da carta (MORAES, 2007a, p. 92):

\footnotetext{
se elas às vezes se contentam em mencionar uma obra em processo de criação, elas também permitem, em alguns casos exemplares, seguir quadro a quadro - suas diversas fases: do projeto informe, ainda mal desenhado, nomeado com dificuldade, até a publicação do livro, seguida de sua recepção pela crítica (que a carta comenta) e, enfim, o seu lento e inexorável esvanecimento nas águas turvas da memória (da qual a série de cartas pode se tornar o doloroso testemunho)... (DIAZ, 2007, p. 123).
}

A carta, enquanto terreno de experiência e partilha, figura como lugar privilegiado no desenvolvimento literário. Perpetuam-se nela os resquícios de um trabalho miúdo ligado ao nascimento e à crítica do texto literário, transformando a correspondência em um fértil "laboratório" da criação, onde se pode acompanhar o engendramento do texto nas filigramas, observar os meandros da análise e da interpretação e até pontuar motivações externas que irão "precisar a circunstância" do texto. Na correspondência de Mário de Andrade e Câmara Cascudo, o encontro com o alter ego desemboca diretamente nos "arquivos da criação" (MORAES, 2007a, p. 92). 
Mário, também fará nas cartas a apresentação de projetos de livros, entre eles, podemos citar alguns exemplos. No primeiro deles, presente na carta de vinte e seis de novembro de 1925, o escritor paulista informa Cascudo do lançamento de um livro e um projeto que estava se dedicando: Losango cáqui e Amar, verbo intransitivo, que naquela época, não estava com título definido, tendo podido vir a ser intitulado Livro de Amor:

Qualquer dia de janeiro ou fevereiro estoura por aí também o meu livro novo, Losango cáqui já se imprimindo. São versos, porém sem o aspecto e gosto dos de Paulicéia. Outro aspecto e outro gosto. Livro intimo, sensações delicadinhas, coisa mais sutil talvez. Não sei se é bom, se é ruim, mais diário de sensações que poesia propriamente. E já estou tão longe dele! Agora ando inventando um livro novo, de que não escrevi nenhuma linha ainda porém que me parece meu estado atual de sensibilidade e ideia. Veremos. Talvez se chame Livro de Amor, não sei...É [uma] misturada de versos e prosa, mais ou menos no gênero da Vita nuova de Dante (...) (MA, 26-XI-1925, apud, CASCUDO, 2010a, p. 76).

O livro Losango cáqui não foi publicado dentro do prazo esperado. Mário parece não se incomodar muito com isso. Conforme podemos ver em uma carta dos primeiros dias de janeiro de 1926, o autor ficou animado com um artigo de Luís E. Soto que comenta A Escrava que não é Isaura, agradece Cascudo por aproximá-lo do escritor argentino e como o livro estava "sai-não-sai" ainda esperaria alguns dias, cinco ou seis para o envio. Um ponto importante desta carta, é que Mário pede para que Cascudo faça crítica ao texto, pois se tratava de uma obra que destoava das demais que produzira até aquele momento; e reclama "se não gostar fale e os reparos que descobrir fale também que você encontra em mim um sujeito que jamais se ofendeu com censuras":

Porém antes que me esqueça te conto que recebi anteontem uma carta gentilíssima do Soto com um artigo sobre a Escrava saído em Renovación. Deus lhe pague o que você vem fazendo por mim. Vou esperar uns cinco ou seis dias pra responder pro Soto, porque assim posso mandar pra ele o meu livro novo que está sai-não-sai. Você sabe qual é, o Losango cáqui, versos líricos, coisa intíma, coisa de coração moderno. Não tem o caráter humanitário nem nacionalista dos meus últimos versos Vamos ver se você gostará. Mas olhe, se não gostar fale e os reparos que descobrir fale também que você encontra em 
mim um sujeito que jamais se ofendeu com censuras e que a se mesmo se vive censurando numa conta. Infelizmente seria indiscreto fazendo censuras e críticas de meus próprios livros... (MA, I-1926, Id. Ibidem, p. 84) ${ }^{84}$.

Quando falara que não se ofendia com críticas e censuras, parece que não se importava muito com as que provinham da pena amiga; com as demais, prefigurava haver um certo desconforto. Em carta do mês seguinte, em três de fevereiro de 1926, ao mandar "uma porrada de coisas", livro, jornal e brigas, desejava que o Losango agradasse ao amigo. Como a Paulicéia, o respectivo livro estava causando um verdadeiro mal estar. A passagem que veremos a seguir é muito relevante porque mostra Mário fazendo uma crítica muito forte a seu próprio livro e aos elementos estéticos nele presente; contudo, afirma que o mesmo seria um livro de passagem, não comungava mais com aquelas ideias, acreditava que Cascudo, para quem vivia dando sua alma em cartas, muito saberia compreender que aquela obra nada mais seria que a busca de perfeição no fazer poético-literário:

Aqui vai uma porrada de coisas pra você. Livro, jornal e brigas. Desejo que o livro te agrade. Também se não agradar fale e nada de delicadezas comigo, hein. Não é por causa duma opinião contraditória a um livro meu que diminuirá um minutinho de minha amizade por você. Como a Paulicéia, está causando uma trapalhada medonha. Uns acham loucura, outros confundem com o desvairismo de Paulicéia, o que é constituído até com excesso de teoria, outros acham incompreensível, outros acham a melhor coisa que jamais fiz, melhor mesmo que as últimas. Tudo isso me parece exagero sobre exagero. $\mathrm{O}$ Losango não é mais que um livro de passagem. Tem coisas dentro dele que gosto deveras porém é um livro sintomático de passagem. Era lógico que para um espírito curioso e sério como o meu o intuitivismo de Paulicéia em que acertei à vezes por acaso, não me podia contentar. (...) Agora estou noutra inda menos sensacionalista e mais espiritual. Não sei francamente onde irei parar porém você para

\footnotetext{
${ }^{84}$ Do mesmo modo se dirigiu a Joaquim Inojosa em carta de treze de maio de 1926: (...) “Como é que que você recebeu meu livro e nem acusou recebimento! Ou não teria por acaso recebido o 'Losango Cáqui'? Se não recebeu é que se extraviou. Eu mandei e mandei registrado. Desconfio que foi preguiça de você. Ou então porque não gostou e teve receio de me magoar com opinião franca? Se esta última razão foi a de você, garanto que se engana redondamente a meu respeito. Diga e pense o que quiser das minhas obras sem receio e com franqueza. Sempre acatei a opinião dos amigos e jamais me zanguei com ela. Em todo caso você está na obrigação de me mandar dizer se recebeu ou não o Losango pra que eu sossegue ou mande outro" (MA, 13-V-1926, apud, INOJOSA, 1968, v. 2, p. 343-344).
} 
quem vivo dando minha alma por cartas sabe perfeitamente a enorme sinceridade minha e que essa mutação constante não é mais que a sede clássica de perfeição. Perfeição propriamente não, expressão de mim mesmo. (MA, 3-II- 1926, Id. Ibidem, p. 87).

No dia dezenove de fevereiro, volta a se lastimar com Cascudo a respeito da polêmica ainda causada pela publicação de Losango, pretendia escrever do ano de 1926 até o começo de 1927, seu livro sobre a História da música, na tentativa de estancar os insultos feitos de forma mais perversa e estúpida que veio com a Paulicéia. Como acreditava que o orgulho pessoal era a coisa mais importante que o indivíduo poderia ter, responderia com orgulho pessoal: mais um livro de estudos pra desnortear ainda mais aqueles filhos-da-p...:

\footnotetext{
Tomei por obrigação botar na rua este ano a minha História da música e o mais tardar no começo do ano que vem há-de estar escrita custe isso o que custar. Se tivesse tempo falaria porquê. Enfim é por causa do escândalo do Losango cáqui, não só absolutamente incompreendido mas que deu razão a uma tempestade de insultos mais perversa e tão forte como a que veio com Pauliceia. A essa estupidez humana eu respondo com orgulho pessoal: mais um livro de estudo pra desnortear inda mais esses filhos-da-puta (...) (MA, 19-II-1926, Id. Ibidem, p. 91).
}

No dia vinte e dois de julho de 1926, Mário anuncia mais duas obras Primeiro Andar e Amar, verbo intransitivo, informa que tinha dedicado um dos contos de primeiro andar ao amigo potiguar, depois voltou atrás, pois esperava ofertar coisa maior que pudesse guardar o nome forte desta amizade:

Creio que para setembro terei o Primeiro andar pronto e para outubro o Amar, verbo intransitivo. Tinha dedicado a você um dos contos do Primeiro andar porém acabo de tirar a dedicatória. Espero em Deus que hei de ter vida e forças pra te dar coisas mais valiosas e guardar o nome forte da nossa amizade em qualquer coisa de vida maior. (...) (MA, 22-VII-1926, Id. Ibidem, p. 114).

Em resposta, Cascudo, faz dois comentários. O primeiro, diz respeito à rapidez com que Mário conclama os títulos de seus novos trabalhos; toda vez que Cascudo 
pensava em elaborar uma crônica, logo tinha que rasgar e começar novamente. O segundo aborda a questão das dedicatórias, frisando que bem ou mal eles estavam independentes de provas tipográficas para endosso à aliança intelectual que mantinham; Cascudo se sentia íntimo de Mário, por isso, enfatizou a expressão "Primeiros no coração e últimos na mesa", vejamos as passagens:

V. fala de Amar e de Primeiro andar e onde está o Clã de jabuti ${ }^{85}$ bicho de minha especial deferência e estima? V. é um anunciador de títulos despertadores de crônicas. Cada um deles vai pedindo um artigo. Vez por outra escrevo um e guardo. Na outra carta V. não fala no livro e eu rasgo o artigo. E sucessivamente...

(...)

Não pense em mim nas dedicatórias. Distribuas em troco miúdo da estima impressa entre os mais apressados. Eu tomo o que é meu em V. - uma parte grande de espírito e de pensamento. Nós, de bem e de mal, estamos independentes de provas tipográficas para endosso à aliança. V. entendeu? Pertenço aos de casa. Primeiros no coração e últimos na mesa (CC, 8-VIII-1926, Id. Ibidem, p. 117).

Outra obra de Mário de Andrade mencionada na correspondência seria Macunaíma: o herói sem nenhum caráter. Em carta de primeiro de março de 1927, Mário dá notícia de que um amigo em comum, o Andrade Murici, teria ido a sua casa para visita-lo e mencionado que conhecia Cascudo, confidenciando que o amigo potiguar não conseguiria se adaptar em nenhuma outra parte a não ser no Nordeste, teria ficado com a impressão de ser esta condição um "traço psicológico adorável”. Mas que não se prolongaria neste assunto conversaria sobre coisa séria, precisava da ajuda de Cascudo há algum tempo, e sempre esquecia de dizer a razão e necessidade; numa longa passagem esmiúça todo o processo de criação de Macunaíma:

Segunda passada o Andrade Murici veio aqui em casa me visitar e sube que ele conhece você. Me falou que você não pode se adaptar em

\footnotetext{
${ }^{85}$ Certa feita, ao comentar com maior intensidade a obra Clã de Jabuti, Cascudo chega a dizer que este seria o seu melhor livro de poemas e que através deste, a poesia de Mário se tornaria maior que a de Manuel Bandeira: "Clã do Jabuti é o seu melhor livro de poemas, como brasilidade pura e sensível. Não sendo livro de tese nem de pessoísmo estético (Losango Cáqui e neste Clã os poemas das páginas 37 e 93) clã é bandeira de tribo. Cada um encontra cheiros da terra conhecida. V. foi feliz no título. É livro de Clã. Clã dos estados brasileiros. (...) Manu não é deste jeito. Manu imobiliza tudo. Estiliza. Manu é miniaturista. Japonês. (...) Os poemas grandes do Clã, 'Carnaval' e 'Noturno' pedem 'plaquete'. Uma 'plaquete' ilustrada e, se possível, musicada”. (...) (CC, 2-II-1928, Id. Ibidem, p. 143).
} 
parte nenhuma só aí no Nordeste, é verdade? Achei isso como traço psicológico adorável. Bem conversemos coisa séria. Estou pra pedir uma coisa pra você e ando me esquecendo. Se trata disto. Não sei se já te contei ou não mas em dezembro estive na fazenda dum tio e... e escrevi um romance. Romance ou coisa que o valha, nem sei como pode se chamar aquilo. Em todo caso chama-se Macunaíma. É um herói taulipangue bastante cômico. Fiz com ele um livro que me parece não está ruim e sairá em janeiro ou adiante, do ano que vem. Minha intenção foi esta: aproveitar no máximo possível lendas tradições costumes frases feitas etc. brasileiros. E tudo debaixo dum caráter sempre lendário porém como lenda de índio e negro. O livro quase não tem nenhum caso inventado por mim, tudo são lendas que relato. Só uma descrição de macumba carioca, uma carta escrita por Macunaíma e uns dois ou três passos do livro são de invenção minha, o resto tudo são lendas relatadas tais como são ou adaptadas ao momento do livro com pequenos desvios de intenção. Por exemplo a lenda da Velha Gulosa que vem no Barbosa Rodrigues está sutilmente deformada no livro pra se perceber que é uma caftina. Um dos meus cuidados foi tirar toda a geografia do livro. Misturei completamente o Brasil inteirinho como tem sido minha preocupação desde que tentei me abrasileirar e trabalhar o material brasileiro. Tenho muito medo de ficar regionalista e me exotizar pro resto do Brasil. Assim lendas do Norte botei no Sul, misturo palavras gaúchas com modismos nordestinos ponho plantas do sul no Norte e animais do Norte no Sul etc etc. Enfim é um livro bem tendenciosamente brasileiro. Ora o que eu quero de você é isto: você tem recolhido lendas e tradições aí no Nordeste. Meu livro está escrito porém tenho ainda um ano pra matutar sobre ele e modifica-lo à vontade. Eu queria botar uma lenda aí do Nordeste nele, você pode me ceder uma das que recolheu? Quero uma bem lírica, sentimental se for possível. Enfim, o mais lírica possível. Escolha das que você tem umas duas ou três e me mande. Botarei uma só e guardarei cuidadosamente as outras pra você mesmo. (...) (MA, 1-III-1927, Id. Ibidem, p. 123).

Em carta de primeiro de outubro de 1928, Cascudo acusa o recebimento de Macunaíma e embora não tenha podido ler o livro, fala sobre suas impressões mais apressadas; ia também acompanhando os registros sobre o livro, deixaria o mais para conversar pessoalmente, pois em princípios de dezembro, Mário estaria viajando para Natal, para ser seu hóspede, viagem que se estenderia por Paraíba e Pernambuco: 
Em Natal não pude ler Macunaíma. Li, verdade seja, trechos às pressas. O bastante pra dizer que $\mathrm{V}$. pode fechar o firo brasileiro. Porque todo o Brasil está ali. Vou aos poucos lendo os registros sobre o livro. Farejo que eles não assuntam a dispersão propositada do tema. O hábito de ver é diferente do rever. Macunaíma é revisão do Brasileiro. Reúne-o. Catar um detalhe para análise é besteira grossa. Demais, querido Mário, eu vou achando um sabor de canto cíclico, de canção de gesta, uma coisa à saga, reconto de hierodrama. $\mathrm{O}$ que ataranta é o linguajar brasileiro. E a mistura que V. fez dos temas. A mistura deu o retrato dos instintos. Enfim, muita coisa pra conversar pessoalmente. Escreva. Ficarei aqui [Recife] até princípios de dezembro. Não é esta a época de sua vinda? Não está combinado que V. irá diretamente a Natal, depois Paraíba (capital) vindo carnavalar em Recife? Bento é que disse esta história. E até combinamos programas (CC, 1-X-1928, Id. Ibidem, p. 149).

Durante o ano de 1928, Cascudo trataria de um projeto de livro sobre a História do Rio Grande do Norte, mostrando mais uma vez que embora se dedicasse à crítica literária, o campo da produção historiográfica seria pelo visto de sua maior predileção:

\footnotetext{
Eu continuo tomando notas para uma História do Rio Grande do Norte em três volumes. Divido-os assim: Expansão geográfica, conquista, colonização, povoamento, fixação do contorno territorial. Segundo volume: administração, política, expressão econômica, história da sociedade (genealogia das principais famílias, núcleos de irradiação política, indumentária, culinária, costumes, festas, música, religião). Terceiro volume: História da Literatura. Gosta do plano? Quer sugerir alguma coisa? Devo dizer que cada volume compreende desde a conquista até atualmente (CC, 1-I-1928, Id. Ibidem, p. 139).
}

Mário, em carta de vinte e dois de janeiro de 1928, alude ao comentário de Cascudo sobre sua nota em torno do livro López do Paraguay, concordava que o amigo tinha razão no reclame, lá sabia sobre história para "comentar obra de um 'bicho"” feito Cascudo? Tinha se limitado mesmo só em chamar atenção sobre a obra, queria mesmo era aconselhar o amigo, para que ao invés de se voltar a mais um projeto como o que fora mencionado acima, que se dedicasse a concluir o projeto apresentado anteriormente sobre o livro Lendas e Tradições em 1925; considerava o projeto do "enorme livrão em 
três volumes" "cotuba", mas via que nessa porrada de "projetos encolarados" o espírito dispersivo se interrompendo na dança e não deixando Cascudo "puxar fieira direito", sugeria que o amigo tomasse cuidado:

Você fez uma observação muito engraçada sobre o artigo meu sobre o López. Tem razão. Porém que que você queria que eu falasse, lá sei história então pra comentar um bicho feito você! Deus te livre! Me limitei falando umas bobagens, no fundo era só desejo de chamar atenção sobre seu livro mais nada. Praquê que você em vez de dar fim pras Lendas e Tradições já encaminhadas se mete fazendo mais projeto de livro e inda mais o enorme do livrão em três volumes que projetou? Que o projeto é cotuba nem se discute porém o que vejo nessa porrada de projetos encolarados é o espírito dispersivo se intrometendo na dança e não deixando você puxar fieira direito. Tome cuidado com isso. Não posso discutir se um livro valerá mais a pena fazer que outro, ambos têm interesse brasileiro igual. Pra mim que só conheço História pela rama prefiro o das tradições (...) (MA, 22-I1928, Id. Ibidem, p. 141).

Como se pode constatar ao longo da leitura da correspondência de Mário e Cascudo, as obras ou os projetos editoriais cascudeanos, até a famosa carta marioandradina de nove de julho de 1937, são predominantemente voltados para a História, embora não deixe de dialogar com o campo da crítica literária, ou ainda ensaiar alguns estudos no campo do folclore. Um elemento que se apresenta comumente na passagem supracitada e na carta de nove de junho de 1937 é a tentativa de Mário em aconselhar o amigo, comentando a respeito de sua esquiva em dar opinião sobre os estudos de Cascudo até aquele instante; tentava justificar que achava o amigo tão quanto vaidoso, talvez estivesse enganado, tentava apontar outras possibilidades e caminhos, pois acreditava que Cascudo era maior do que tudo que havia produzido:

Geralmente não gosto abertamente deles [artigos], e agora careço dizer por quê. Você aliás deve ter notado isso porque nunca deixei de pôr um ar de vago ao falar em trabalhos de você. Minhas cartas, nesse sentido, sempre foram com algumas reticências, que no entanto, jamais existiram quando eu te incitava a trabalhar e dava deixas sobre assuntos em que você podia produzir obras de real valor. Porque não terei sido totalmente franco? Meu Deus! Nem sei bem... Um pouco de 
fadiga, um pouco medo de ferir você porque sinto você um bocado vaidoso, talvez erre. Mas nunca deixei de considerar o valor de você e a sua inteligência. Minha convicção é que você vale muito mais de que o que já produziu ${ }^{86}$. (...) (MA, 9-VI-1937, Id. Ibidem, p. 292293).

Concordamos com Marcos A. de Moraes (2007a) quando aponta que a carta anterior de 1928 enviada a Câmara Cascudo continha um assunto bem difícil de ser tratado, ocupando o cerne da mensagem. Mário de Andrade possivelmente teria escrito para criticar o "espírito dispersivo" do amigo, que estaria interrompendo um estudo sobre "lendas e tradições" para empreender projetos mais vultuosos e menos importantes. Cuidadoso em expor seu parecer, Mário, não menospreza os novos caminhos de pesquisa que Cascudo pretendia seguir, afinal, "o projeto é cotuba nem se discute" e possuía 'interesse brasileiro igual", mas, visivelmente, aposta no livro "das tradições" e queria vê-lo realizado em primeiro lugar. Era preciso, porém, dizer isso com cuidado, colocando o interlocutor em posição de superioridade ("lá sei história então pra comentar um bicho feito você"), desenvolvendo um discurso que se apropria da vivência do outro e servindo-se da sintaxe maleável da fala para se tornar mais próximo. O essencial estava dito - "Tome cuidado" - , mas envolto em uma enunciação epistolar que tenta apagar qualquer vestígio de imposição. O próprio conjunto da carta dissimulou a dureza dessa admoestação. Tudo o mais que ali aparece, pode ser tomado como recursos de aproximação que parecem somente estofar a aspereza do conselho (MORAES, 2007a, p. 94).

Já na carta de nove de junho de 1937, como bem demonstrou Moraes (2010), é possível perceber que estando atento à orientação intelectual de Câmara Cascudo, refletida nas publicações dele, Mário, na contramão de estudos históricos "de alcance quase nenhum" e de uma postura eminentemente erudita, escusada, de modo exclusivo, em livros e leituras, põe em xeque certo "ânimo aristocrático" do amigo. Analisada no

\footnotetext{
${ }^{86}$ Sobre a opinião de Mário emitida nesta carta, Cascudo responderá em carta de 18 de julho de 1937 que não iria defender seus livros seria autoelogio e não tinha vaidade desse tamanho, melhor seria calar, mas desabafa dizendo que: (...) "Tenho a impressão de que você sempre me teve como uma força em potencial, uma grandeza in being. É um elogio mas é sincero. Julgou-me pelo que eu seria capaz e nunca pelo que fiz. Não só se deduz pelos doze anos que você esperou para dizer-me, assim como pelo silêncio anterior. Não posso escrever uma só palavra justificativa de tudo quanto tenho publicado. Seria endossar a vaidade denunciada por você. E não há compensação de ordem alguma para nós dois um entendimento 'literário' depois da lealdade de sua confissão...ou auto de fé" (CC, 18-VII-1937, Id. Ibidem, p. 297). Com o passar do tempo, as arestas foram aparadas e amizade entre os dois perdurará até o fim da vida de Mário de Andrade.
} 
contexto histórico e dentro de uma perspectiva biográfica, a missiva de crua "franqueza" dirigida a Cascudo enforma, na realidade, uma das etapas do projeto pedagógico vigente na epistolografia mariodeandradiana, ou seja, aquela fase em que o remetente instaura um curto-circuito na correspondência, suscitando a reflexão do interlocutor, o debate e a eventual superação de posicionamentos estagnados. Em outra direção, a carta documenta as linhas mestras do pensamento do escritor no que tange á definição das diretrizes científicas dos estudos voltados para a apreensão dos "nossos costumes, nossas tradições populares, nossos caracteres raciais", perspectiva teórica e metodológica tributária, em grande medida, das orientações da professora francesa Dina Lévi-Strauss, do Musée de l'Homme parisiense, responsável em 1936, pelo Curso de Etnografia no Departamento de Cultura. A fundamentação científica nos estudos da cultura do povo equivale, para Mário, à descoberta da estrada real que levaria ao conhecimento aprofundado da identidade brasileira; assim, o eventual descaminho de alguém da estatura intelectual de Câmara Cascudo, afortunado por ter "a riqueza folclórica (...) passando na rua a qualquer hora" equivalia a um irreparável desfalque na produção de saber sobre a expressão popular, circunstância que era preciso a todo custo evitar. Por isso, talvez, parecesse justo a Mário de Andrade também colocar "todas as cartas na mesa”, em uma jogada temerária que poderia desencadear o rompimento definitivo da amizade com Cascudo ou promissoras contribuições culturais (MORAES, 2010, p. 378-379).

\subsection{Correspondência de Câmara Cascudo e Joaquim Inojosa (1924-1926)}

Ao se falar da efervescência cultural ocorrida em Recife em meados da década de 1920, não podemos esquecer-nos de Joaquim Inojosa, jornalista e também estudante de Direito na Faculdade do Recife à época de Cascudo, que em Pernambuco, em 1924, escreveu a plaquete A Arte Moderna, carta /panfleto que repercutiu em todo o Nordeste. A carta dava um destaque especial a Graça Aranha (em virtude do discurso de rompimento deste, com a Academia Brasileira de Letras); historiava a semana de 1922, informava sobre o movimento em Pernambuco, falava de suas primeiras repercussões no Pará e no Rio Grande do Norte e apelava para que a Paraíba (especialmente o grupo da revista Era Nova, a quem a carta era dirigida) aderisse ao Modernismo. A importância da carta reside no fato de ter divulgado o Modernismo no Nordeste e 
também ter divulgado o que se passava no Nordeste/Norte do Brasil (ARAÚJO, 1995, p. 13; AZEVEDO, 1996, p. 61-62).

Durante o ano de 1922, a par de uma grande agitação política que abalava o país, desenvolvia-se, sobretudo nos setores oficiais um largo movimento de propaganda em torno das comemorações do centenário da independência do Brasil. Tais fatos, somados à dificuldade de comunicação entre os diversos Estados, retardaram a divulgação do Modernismo no país. Ademais, como as ligações das províncias se davam mais diretamente com o Rio de Janeiro, então capital da República, a circunstância de a Semana de Arte Moderna ter sido realizada em São Paulo em nada ajudou a sua divulgação.

Justamente para participar do $1^{\circ}$ Congresso Internacional de Estudantes, por ocasião das festas do centenário da independência, partia do Recife para o Rio de Janeiro, em agosto de 1922, uma comitiva de discentes. O secretário dessa comitiva é o jovem estudante e jornalista Joaquim Inojosa. A bordo do "Curvelo", pôde ele, juntamente com Raul Bopp ${ }^{87}$ - que deixava o Recife - tomar contato com a obra de Antônio Ferro, pois a esposa deste, a poetisa Fernanda Castro, emprestava-lhes as obras do escritor futurista português. "Todas as noites", escreveria Joaquim Inojosa em 1923, "realizávamos horas literárias. E ouvíamos a sua voz, no ritmo verde da poesia". E este terá sido o seu primeiro contato com o futurismo, antecipando o que viria a acontecer em São Paulo (AZEVEDO, 1996, p. 41):

\footnotetext{
Nessas deliciosas horas de arte, de estilo, de vibração, Fernanda Castro, espôsa de Antônio Ferro, declamará versos de sua lavra. É poetisa que se libertou das fórmulas antigas. Não vai dizer o que D. ${ }^{\text {a }}$ Rosalina disse.

Conheci-a a bordo do 'Curvelo', de viagem ao Rio. Ela nos pôs em contato mais direto com Antônio Ferro, emprestando-nos obras que Raul Bopp devorara com a sua satisfação de boêmio intelectual e a sua cabeleira de filho legítimo das musas.

Tôdas as noite realizávamos horas literárias. E ouvíamos a sua voz, no ritmo verde da poesia (INOJOSA, 1968, v.2, p. 28).
}

Em 1923, refletiria Joaquim Inojosa em uma de suas crônicas: "Viajar ao Sul e não visitar São Paulo é cometer um erro; maior erro ainda, visitando São Paulo, não

\footnotetext{
${ }^{87}$ Em nota, Inojosa informou que Raul Bopp, embora não integrasse a "embaixada", seguia no mesmo navio, despedindo-se de Recife, onde estudara (INOJOSA, 1968, p. 28, n. 8).
} 
estudar a sua intelectualidade, especialmente seus novos" (Id. Ibidem, p. 47). Assim é que do Rio ele vai a São Paulo, debaixo de certa apreensão que logo será desfeita. Procurando conhecer colegas de profissão, vai à redação do Correio Paulistano, onde o recebeu Menotti del Picchia: "Franco olhar de alegria", recordará Inojosa, "recebeu-me como se conhecidos fôramos". Menotti falara-lhe de São Paulo e falou de literatura: "Em sessenta rápidos minutos havia destruído uma literatura e erguido sobre as cinzas dos livros empoeirados um templo moderno, onde ajoelhou e rezou fervorosamente o Evangelho Novo, o Credo de hoje". Seria o ponto de partida para o contato com os modernistas. De fato, ainda na redação do Correio Paulistano é apresentado, por Menotti, a Oswald de Andrade, que se encarrega de catequizar o neófito sobre o "novo Evangelho de Arte". Discutem sobre o momento literário de Pernambuco, confessando o crítico literário pernambucano que em Recife eram todos... passadistas" (AZEVEDO, 1996, p. 41-42; INOJOSA, 1968, v. 2, p. 20).

Os contatos se sucediam. Visitou Guilherme de Almeida no escritório de advocacia de seu pai. A "camaradagem" logo se transformará em "amizade sincera e inquebrantável solidariedade intelectual" (INOJOSA, 1968, p. 154). É convidado para uma visita ao atelier de Tarsila do Amaral, onde passa uma "tarde de arte", juntamente com outros intelectuais paulistas; Anita e Tarsila pintam o seu retrato; e ainda recebe "um punhado de livros novos", como escrevera o correspondente do Jornal do Commercio de Recife em crônica publicada naquele jornal, a vinte de outubro de 1922. Participa também de uma reunião noturna do grupo de Klaxon na casa de Mário de Andrade (AZEVEDO, 1996, p. 42):

Não se mede facilmente a importância dessa movimentação intelectual de São Paulo. Ali os propulsores principais trabalham muito com um espírito de solidariedade inquebrantável. Não desperdiçam talento em noitadas inúteis. Reúnem-se sempre; discutem, e dêsse trocar de idéias, idéias novas surgem. Numa dessas horas de arte em casa de Mário de Andrade (primeiro andar silencioso, mesas, estantes, revistas de arte, livros, quadros modernos pelas paredes): Oswald de Andrade lê capítulos fortes do segundo volume da 'Trilogia do Exílio', revelando na fisionomia o poder de observação da sua inteligência privilegiada; Mário de Andrade diz trechos de uma conferência sôbre a poesia moderna; Menotti e Guilherme recitam com perfeição e encanto; Rubens de Morais crítica obras de arte, com todo o 
entusiasmo de seu talento môço; (...) até alta madrugada, vendo-se lá fora, o cair lento e sensual da garoa... INOJOSA, 1968, v.2, p. 11).

O jovem crítico pernambucano estava de todo contagiado pelo entusiasmo dos paulistas. Seu comportamento é o de um convertido, logo ungido apóstolo, predestinado a pregar entre os "gentios" a mensagem do "credo novo". O deslumbramento impedia-o de assumir uma posição crítica diante dos fatos que presenciava, diante das ideias que assimilava. Não importava discutir o conteúdo da mensagem ou, quem sabe, a sua aplicabilidade em outra situação que, em difundir a nova mensagem, consubstanciada, para Inojosa, na tarefa de destruir o passadismo. Como agiam, segundo entendeu, os "klaxistas" de São Paulo. E é isso que fará tão logo chegue a Pernambuco (AZEVEDO, 1996, p. 42), como também conclamará a Era Nova a ser a "klaxon parahibana":

\footnotetext{
E' em sínthese, essa a situação do movimento moderno no Recife.
}

Resta-me, agora, pedir que a Parahiba nos acompanhe.

(...)

Porque, ou a Parahiba se filia ao movimento renovador, ou em arte, ficará no Morro do Castello da antiguidade.

(...)

Está decretada, ahi tambem, a fallencia da arte antiga.

Seja a Era Nova o porta-voz de todos os clamores de renovação, e assim terá cumprido a sua mais nobre finalidade.

Seja a Klaxon parahibana (INOJOSA, 1984, p. 39).

O registro histórico da correspondência entre Luís da Câmara Cascudo e Joaquim Inojosa, aparece pela primeira vez em $O$ Movimento Modernista em Pernambuco (1968-1969), livro organizado pelo próprio Inojosa com o objetivo de documentar a história do Modernismo na região Nordeste do Brasil. Às treze cartas enviadas a Inojosa por Cascudo, durante os anos de 1920, juntam-se outros documentos autografados por diversos intelectuais, todos apresentados como testemunhas da história daquele movimento. Além das documentações presente na respectiva obra, Araújo (2012), encontrou no Ludovicus - Instituto Câmara Cascudo, em sua pesquisa de pósdoutoramento, três cartas de Inojosa enviadas a Cascudo durante a década de 1920. (ARAÚJO, 2012, p. 37; INOJOSA, 1968, v.2, p. 377-388).

Uma justificativa para esta diminuta correspondência seria a grande proximidade existente entre os correspondentes entre 1924 e 1928, Cascudo estará entre suas "idas e 
vindas" de Natal a Recife para concluir seu bacharelado na Faculdade de Direito no Recife. Lá, Inojosa também estará realizando o respectivo curso e assim sendo, a função das missivas era bastante prática, importando mais para Cascudo, a agilidade da informação do que propriamente o cultivo da amizade existente. A possibilidade de real convivência subtrairia à carta determinados assuntos que certamente eram tratados pessoalmente, por isso ocorre uma menor quantidade de cartas nesse período que aqui analisamos (ARAÚJO, 2012, p. 48-49). O que ocorrerá de forma muito diferente, quando os dois amigos, distanciados pelo tempo e espaço, manterão um diálogo mais intenso, como veremos no capítulo posterior.

Na primeira das cartas que Cascudo envia a Inojosa, temos por seu intermédio as congratulações ao amigo pela publicação de A Arte Moderna:

\footnotetext{
Ahi vai o registo de tua 'Arte Moderna'. Ainda estou em tempo de felicitar-te pelo escândalo.

Resta explicar aos poetas de Recife o que vem ser arte moderna.

Para isto tens cultura, elegância estylistica e coragem (CC, 22-VIII1924, apud, ARAÚJO, 2012, p. 87) ${ }^{88}$.
}

A carta faz referência à resenha escrita por Cascudo sobre a respectiva obra e publicada no jornal natalense $A$ ' Imprensa. No livro manifesto de Inojosa, Câmara Cascudo é conclamado como o divulgador dos ideais da Arte moderna no Rio Grande do Norte:

\begin{abstract}
No Rio Grande do Norte o jornalista Luís da Camara Cascudo, espírito estudioso e de largos conhecimentos literários, abraçou as idéas da Arte Moderna, e o fez com convicção própria das intelligencias moças e fortes (INOJOSA, 1984, p. 29).
\end{abstract}

$\mathrm{Na}$ resenha, que foi escrita e publicada ao mesmo dia que a carta supracitada (vinte e dois de agosto de 1924), vemos Cascudo argumentar que não sendo a Arte Moderna um manifesto, teria Joaquim Inojosa se limitado a historiar a "semana" "doida" no teatro Municipal de São Paulo e "suas brilhantes consequências", que a carta fazia uma visita rápida "pelos mais representativos adeptos nos Estados", pedindo ao editorial da revista Era Nova a adesão do movimento. Em sua concepção a escrita

\footnotetext{
${ }^{88}$ Registramos neste ponto do texto que todas as referências feitas em torno da correspondência de Cascudo e Inojosa neste estudo, terão por base as transcrições compiladas por Araújo (2012).
} 
elegante da carta de Inojosa, pelo seu teor combativo teria feito "mais barulho que a confederação do Equador". Finaliza o texto em tom de agradecimento pelo reconhecimento e menção de seu nome pelos "galões do generalato" da Arte Moderna no Rio Grande do Norte, mesmo não sabendo qual bandeira lhe batia ou agia. Argumenta por fim que a única teoria literária que lhe seduzia, era a sua própria:

\begin{abstract}
Não sendo um manifesto o sr. Joaquim Inojosa limitou-se a historiar a 'semana' doida no teatro Municipal de S. Paulo e suas brilhantes consequências. Faz uma visita rápida pelos mais representativos adeptos nos estados e pede (como se isto se pedisse) a adesão da 'Era Nova' ao movimento. Como está escrita elegantemente, salpicada de citações e alguns alfinetes, a 'carta' fez mais barulho que a confederação do Equador. Isto lisongeia. Palavra de honra.

(...)

No Rio Grande do Norte coube-me os galões do generalato. Vindo de tais mãos dadivosas não recuso. Mas, ponho restrições. Não sei sob qual bandeira me bato ou ajo.

Até aqui a única teoria literária que me seduz é a minha. Há a compensação de ser eu só. E já é muito ${ }^{89}$ (CASCUDO, 1924, apud, ARAÚJO, 1995, p. 108-105).
\end{abstract}

Chamamos atenção para dois argumentos mencionados pelo escritor potiguar na citação acima apresentada: "Não sei sob qual bandeira me bato ou ajo" e "Até aqui a única teoria literária que me seduz é a minha”. Estes aspectos são muito relevantes no que compete ao maior esclarecimento aos estudiosos que se apressam em atrelar Cascudo em alguma corrente ideológica definitiva, passadista ou futurista, regionalista ou modernista. Embora aqui neste capítulo estejamos a contemplar o entusiasmo de Câmara Cascudo com a campanha modernista, podemos ver no capítulo anterior e aqui mesmo que o escritor não deixa de se abrir para outras tendências "passadistas", como confessou ao amigo Inojosa no post scriptum da carta de doze de janeiro de 1925:

$$
\begin{aligned}
& \text { P.S. } \\
& \text { meu irmão: }
\end{aligned}
$$

\footnotetext{
${ }^{89}$ Em uma última alusão a A Arte Moderna no corpo da correspondência de Cascudo e Inojosa, temos algo que contradiz essa passagem; em missiva do dia nove de setembro de 1925, Cascudo fala do chamamento feito a alguns dos poetas norte-rio-grandenses de sua época: (...) 'E a 'Arte Moderna'? Aqui tenho feito maravilhas. Arrebanhei Othoniel Menezes, Jorge Fernandes, Luís Torres, Pedro Lopes Júnior (...) grandes nomes das catorze patas do soneto". (...) (CC, 9-IX-1925, apud, ARAÚJO, 2012, p. 106).
} 
o destino é soberano. Nasci para ser passadista. O Barão de Stuart propôs-me e eu estou feito sócio do Instituto do Ceará (CC, 12-I-1925, apud, ARAÚJO, 2012, p. 93-94).

Sobre este aspecto, Araújo (2012), mostra alguns elementos que reforçam a nossa linha de raciocínio. Para o autor, Câmara Cascudo se reconhecia "passadista" e aceitava a filiação a instituições conservadoras. Nesse mesmo espírito de reverência, apela ao amigo em carta de quatorze de março de 1925: "Não ironize o Archeológico. Fui eleito sócio correspondente" (CC, 14-III-1925, Id. Ibidem, p. 101). No mesmo contexto, informa que publicará um livro - Lendas e Tradições do Nordeste Brasileiro (CC, 9-IX-1925, Id. Ibidem, p. 106) - cujo título, ressaltou o autor, não se encaixava em um campo semântico estrito da vanguarda modernista e sim de respeito às tradições regionais (ARAÚJO, 2012, p. 59).

Como sabemos, a obra não foi publicada, pois se trata do mesmo projeto já discutido por intermédio da correspondência de Cascudo e Mário, em carta de treze de agosto de 1925, Cascudo faz alusão ao mesmo título presente nas cartas de Lendas e Tradições; só em meados de setembro de 1925, o título irá ser alterado para Lendas e Tradições do Nordeste Brasileiro ${ }^{90}$. Este aspecto não é único cruzamento de dados e informações nas duas séries de correspondências, é possível encontrar elementos que aludem também ao problema anterior. Cascudo informa a Mário em carta de nove de dezembro de 1925, por exemplo, que foi "orador oficial" do Instituto Arqueológico nas festas do centenário de D. Pedro II:

Fui ‘orador oficial' do Instituto Arqueológico nas festas do Centenário de D. Pedro II. Fugi 24 horas antes de uma festa oferecida ao meu 'maravilhoso espírito sedutor' (CC, 9-XII-1925, apud, CASCUDO, 2010a, p. 80).

Além desses elementos, outros serão aqui recorrentes. Tal qual fez com Mário de Andrade, Cascudo também aproximou Joaquim Inojosa dos escritores modernos

\footnotetext{
90 Além deste projeto, também é possível encontrar alusão a mais dois trabalhos de Cascudos dessa mesma época, trata-se do López do Paraguay e Buda é santo católico?: (...) "Terminei duas monografias ultra-passadismo-allemão. Uma sobre a catholiciedade de Bouddha e sobre a morte de Solano (o Lopez, da detestável guerra do Paraguay) a outra. Dentro de brevíssimos dias findarei um livro serio - Lendas e tradições onde há muito esforço e muita vontade substituindo cultura e brilho". (...) (CC, 13-VIII-1925, Id. Ibidem, p. 103).
} 
argentinos como Saéz ${ }^{91}$ e Soto ${ }^{92}$. Em carta de vinte e oito de dezembro de1924, Cascudo pede para que Inojosa envie aos amigos platinos alguns exemplares da Arte Moderna:

Mande ao Saéz uns 5 exemplares do nosso trabalho - Arte Moderna. O adresse é - B. Sanchez-Saés - Rivadivia 1731. O do luís Emílio Soto é 15 de Noviembro 1715. Ambos em Buenos-Aires. Mande os dois com dedicatórias. Ao Soto mande uns 4 exemplares (CC, 28-XII1924, apud, ARAÚJO, 2012, p. 89).

Em sua segunda carta enviada a Cascudo no dia nove de março de 1925, Inojosa agradece ao amigo, pois sua plaquete A Arte Moderna seria traduzida e publicada numa revista platina intitulada Inicial:

Não sei como agradecer-lhe as apresentações que me fez aos escriptores de Buenos-Aires. Ambos escreveram-me lindas cartas. O Sanchez-Saez, enviou-me o $\mathrm{n}^{\mathrm{o}} 6$ de Inicial, e comunicou-me iria traduzir, para publicar nessa revista, a minha plaquette - 'A Arte Moderna'. Referem-se a v. com o elogios que v. merece (JI, 9-III1925, Id. Ibidem, p. 95).

Em carta não datada, mas possivelmente posterior a esta, Cascudo convida o amigo a ser ponto de referência entre o Norte e o Sul. E que ninguém poderia competir com Inojosa, pois ele seria "o natural núcleo irradiante por que tem talento e tem bondade" e somente esta característica seria capaz de aproximar as pessoas. Noutra carta de quatorze de março de 1925, sugere que Inojosa escrevesse agradecendo e que ficasse saboreando a fama, pois não precisava mais de intermediário, conclui informando que confiava em sua acuidade intelectual, pois se não, deixaria seu trabalho de lado:

\footnotetext{
${ }^{91}$ Em carta de dezenove de fevereiro de 1925, Braulio Sánchez-Saez dirá a Inojosa: "Es para mí sumo placer, reunir em mi extenso domínio de las amistades brasilenas, la de um culto espiritu, como lo es Vd. Al jusgar por su plaqueta 'El Arte moderno', que por intermédio del talentoso y siempre querido y propagador amigo Luis da Câmara cascudo, tengo em mi poder, y termino en estos momentos de su lectura" (BSS, 19-II-1925, apud, INOJOSA, 1968, v. 3, p. 317).

92 Também dará as boas vinda a Inojosa e comentará o recebimento da Arte Moderna em sua primeira carta: "Por intermédio de nuestro común amgo Luis da Camara Cascudo, recebi su opúsculo 'A Arte Moderna' por cuyo envío le doy las más expressivas gracías" (LES, 6-II-1925, Id. Ibidem, p. 328).
} 
Seja V. o ponto de referência entre o Norte e Sul. Ninguém pode competir. V. é o natural núcleo irradiante por que tem talento e tem bondade. Somente esta virtude aproxima e prende. Eu sirvo de exemplo, caro e querido Inojosa, ou melhor Hinojosa (CC, s/d, Id. Ibidem, p. 97).

Muito bem. Agora é responder aos argentinos e ficar saboreando a fama. V. agora dispensa o intermediario e vá agindo... e vencendo. Se não tivesse inteira confiança em sua acuidade intellectual, deixaria quieto seu trabalho. Mas V. vale. E muito (...) (CC, 14-III-1925, Id. Ibidem, p. 101).

Em retribuição a esse processo de interlocução com escritores argentinos, intermediado por Cascudo, vemos Joaquim Inojosa afirmar em texto publicado no Jornal do Commercio em Recife, no ano de 1924:

O Sr. Luiz da Câmara Cascudo conhece todo o Brasil, e trabalha numa obra de aproximação mental entre os escritores argentinos e brasileiros, especialmente nortistas. Mantém, com os primeiros, assídua correspondência, informando-os da movimentação literária do nosso país. (INOJOSA, 1968, v.2, p. 66).

Comprovando esse diálogo, Araújo (2012) afirma que a ação de Câmara Cascudo como divulgador do Modernismo, para além das fronteiras nacionais, teve como desdobramento a publicação de um artigo de divulgação do movimento brasileiro na Argentina, por Bráulio Sanchez-Saez, na revista Caras y Caretas. Segundo Joaquim Inojosa, o argentino também traduziu A Arte Moderna para o espanhol (ARAÚJO, 2012, p. 53; INOJOSA, 1968, v. 1, p. 119-120; MEDEIROS, 2012, p. 89-90).

Nos últimos aspectos que aqui abordaremos, vemos Cascudo abordar em carta de dez de março de 1925 elementos que ainda trataram da aproximação de Inojosa com os escritores argentinos, alude a publicação da segunda plaquete do divulgador modernista pernambucano, O Brasil brasileiro (1925), da primeira tentativa de viagem de Mário de Andrade ao Nordeste, como de um projeto de revista idealizada ao modo da Klaxon, Modernicéia ${ }^{93}$ :

\footnotetext{
${ }^{93}$ Em possível editorial, vemos as seguintes afirmações: "Não será Klaxon, porque não há tanto o que destruir, visto como o terreno já se acha mais ou menos preparado para a plantação das sementes. Não será Estética, porque constará de sua norma não se contradizer nas atitudes assumidas. Será Modernicéia..." / "Voz espiritual da mocidade pernambucana, trabalhando, tanto quanto possível, para
} 
Não se espante recebendo noutro envelope um retalho de jornal. Revolvendo papeis descobri não ter enviado a V. a transcripção dum artigo do Sáez. (...) O Brasil brasileiro deve ser explendido... mas V. não pôs meu nome na lista dos presenteados. Luis Soto escreveu-me de S. Paulo. Fez-se amigo do Mario de Andrade a quem eu apresentara. Soto publicou em Renovación um artigo sobre a Escrava. Mario esteve vem não vem ao Norte. Fiquei encarregado de avisar a V. e combinar las cósas. Agora diz não vir em 1926. Quer publicar a História da Música. (...) E a Modernicéia? Recife é a terra das revistas nominaes. Lobis-Homen morreu antes de nascer. Morto-Vivo não sahiu. Modernicéia continuará a tradição passadista de abolôecer no nascedouro? Revista de expressão Recife desconhece. V. está indicado pra ter a segunda coragem. A primeira foi a campanha modernista (CC, 10-III-1925, Id. Ibidem, p. 100).

Observando o contexto da carta, percebe-se que havia um estabelecimento de uma rede de sociabilidade entre Mário, Cascudo e Inojosa, onde temas, projetos e intenções eram compartilhados. Em carta de vinte de outubro, por exemplo, Cascudo informará a Mário que havia encontrado o Recife cheio de ideias novas, pois Inojosa queria fundar uma revista chamada Modernicéia (CC, 20-X-1925, apud, CASCUDO, 2010a, p. 74), e tomando as palavras de Cascudo, esta parece não ter sido mais uma revista nominal, morta em seu nascedouro. Em Natal, aconteceria o mesmo com a Potiguarania, projeto cascudeano de uma revista, com um estilo próximo a Paulicéia desvaraida de Mário de Andrade, seria publicada inicialmente em três números, mas que devido às finanças do Rio Grande do Norte não foi ao prelo: "O Potiguarania está pronto. Infelizmente o Estado está horrível de finanças. E eu não quero obrigar o meu amigo dr. José Augusto (que o governa) a publicar" (...) (CC, 30-XII-1925, Id. Ibidem, p. 82).

No que concerne à partilha de manuscritos e pedido de publicação, podemos dizer que tal aspecto também ocorre no corpo da correspondência de Cascudo e Inojosa e mais uma vez Mário é o mote para da discussão: 
Remetto duas poesias minhas ${ }^{94}$. Não abra a bocca... Minhas sim senhor! Uma para o meu (e de V.) Mário e outra inteiramente sua. Sacuda-as na pagina litteraria dos domingos em bom lugar. E, se a tanto me ajudar o engenho, olhe carinhosamente a revisão. E mande uns dois números. Espace os versos. Um em cada domingo. Nos dois teremos tudo feito. (...) (CC, 13-VIII-1925, apud, ARAÚJO, 2012, p. 103).

Neste sentido, concordamos com Araújo (2012), quando demonstra em seu relatório que o corpo dessa correspondência está escalonado em dois blocos. Após a leitura do primeiro bloco de cartas (três de Câmara Cascudo, enviadas em 1924; uma de Joaquim Inojosa, enviada no início de 1925), faz-se necessário acrescentar que o segundo conjunto, composto de doze documentos (dez cartas de Câmara Cascudo, nove delas enviadas em 1925 e uma em 1926; duas de Joaquim Inojosa, uma enviada em 1925 e outra em 1926), não acrescenta novidades em relação ao primeiro, embora se perceba já o incremento no segundo bloco, de alguns elementos avaliativos da campanha modernista. Mantêm-se os assuntos e as atitudes dos missivistas em relação ao movimento literário e cultural da época, assim como a proximidade de ambos com Mário de Andrade. (ARAÚJO, 2012, p. 56) ${ }^{95}$.

\subsection{Correspondência de Joaquim Inojosa e Mário de Andrade (1924-1928)}

Na primeira carta enviada por Mário para Joaquim Inojosa, em vinte e oito de novembro de 1924, vemos o escritor paulista parabenizar o jovem pernambucano pelo seu opúsculo A Arte Moderna, do belo trabalho que estava fazendo em divulgar os ideais modernistas em Pernambuco e no Nordeste; do impacto que vinha causando à mocidade nortista que tanto desejava conhecer; lastimava que ainda fosse muito difícil seu deslocamento, sendo quase um romance de Júlio Verne, e que infelizmente não teria folga necessária par "viver esse romance"; de toda essa juventude vanguardista, Mário informava que só teria entrado em relações com o Luís da Câmara Cascudo, figura de "rico espírito, rapidíssimo":

\footnotetext{
${ }^{94}$ Trata-se de "Kakemono" (Cf. INOJOSA, 1968, v.1, p. 105) e "Shimmy" (Cf. CASCUDO, 2010a, p. 4546).

${ }^{95}$ É preciso que se leve em consideração que aqui não abordamos todos os temas apresentados no corpo da respectiva correspondência. Voltamos nossa atenção aos aspectos que atendem aos objetivos propostos para análise desenvolvida ao longo deste capítulo. Para um maior aprofundamento dos temas: Cf. ARAÚJO (2012).
} 
Joaquim Inojosa, eu já lera o seu opúsculo 'A Arte Moderna' quando me veio às mãos o exemplar que você me mandou pelo Rubens. Relio com prazer. O que você está fazendo aí no norte é realmente um trabalho muito bonito e de grande valor. E benéfico, verá. Aliás pelas próprias citações que você faz de versos daí do norte bem se percebe que esta ânsia de renovação acentuada depois da guerra e alastrada por todo o mundo considerado como civilizado inquieta também essa mocidade nortista que eu tanto desejaria conhecer. Mas como ainda é difícil o Brasil santo Deus! Daqui pra aí é ainda um romance de Júlio Verne e eu não tenho folgas necessárias para viver êsse romance. Só entrei em relações com o Luís da Câmara Cascudo, rico espírito rapidíssimo. Dos outros não sei nada senão o que você conta. E de alguns tive vontade de saber mais alguma coisa. Agradeço-lhe de coração o exemplar de 'Arte Moderna' e breve lhe corresponderei a lembrança com a minha 'Escrava que não é Isaura' 96, já em impressão (...). (MA, 28-XI-1924, apud, INOJOSA, 1968, v.2, p. 339).

Nesta carta, o autor de A Escrava que não é Isaura ainda teve o objetivo de esclarecer sobre os ideais modernistas, estabelecendo uma diferença entre "espírito modernista" e "processos modernistas", talvez considerando conceitos equivocados e confusões relativas aos atores do movimento modernista (Graça Aranha, por exemplo) presentes em A Arte Moderna de Joaquim Inojosa. Preocupava-o, sobretudo, a diferença entre uma poética modernista "universal" e a sua aplicação à "realidade contemporânea" do Brasil à época. Neste sentido, refere-se à necessidade de criar uma arte brasileira e, consequentemente, ao "abrasileiramento do brasileiro" (ARAÚJO, 2012, p. 65):

Veja bem: abrasileiramento do brasileiro não quer dizer regionalismo nem mesmo nacionalismo $=0$ Brasil pros brasileiros. Não é isso. Significa só que o Brasil pra ser civilizado artisticamente, entrar no concerto das nações que hoje em dia dirigem a Civilização da Terra, tem de concorrer pra esse concerto com a sua parte pessoal, como que o singulariza e individualiza, parte essa única que poderá enriquecer e alargar a Civilização. Da mesma forma que do lado prático. Se nós

\footnotetext{
96 Em carta de nove de março de 1925, Inojosa acusa o recebimento da respectiva obra a Câmara Cascudo: (...) 'O Mário de Andrade enviou-me 'A Escrava que não é Isaura' - esplendido livro; livro de um estudioso impenitente”. (JI, 9-III-1925, apud, ARAÚJO, 2012, p. 95).
} 
quiséssemos concorrer pra organização econômica da Terra, com o trigo próprio da Rússia, ou o vinho próprio da França ou da Itália, a nossa colaboração seria inferior, secundária, subversiva e inútil (...). Mas com a borracha, o açúcar e o café e a carne nós podemos alargar, engrandecer a economia humana. Da mesma forma nós só teremos nosso lugar na civilização artística humana no dia em que concorremos com o contingente brasileiro, derivado das nossas necessidades, da nossa formação por meio da nossa mistura racial transformada e recriada pela terra e clima, pro concerto dos homens terrestres. Não acha que eu tenho razão? Mas que trabalho pesado tem de ser o nosso nesse país de expressão tão vaga, em formação ainda como alagadiços páramos dessa Amazônia que me chama diariamente. Cansa, só de pensar. Mas seria ignóbil não pensar e seria infame e desumano não trabalhar nisso. Vamos trabalhar. Quer vir conosco? (MA, 28-XI-1924, apud, INOJOSA, 1968, v. 2, p. 340-341)

Vemos por intermédio desta passagem que ao empregar expressões tão dúbias, Mário procurava ter o desvelo em destrinçar-lhes o significado, de forma didática, facilitando estrategicamente o aprendizado. Abrasileirar o brasileiro "não quer dizer regionalismos nem mesmo nacionalismo $=$ o Brasil para os brasileiros". Significava, na realidade, que o Brasil deveria encontrar meios culturais que o distinguissem de outros países: "nós só teremos nosso lugar na civilização artística humana no dia em que concorremos com o contingente brasileiro, derivado das nossas necessidades, da nossa formação por meio da nossa mistura racial transformada e recriada pela terra e clima, pro concerto dos homens terrestres". A dúvida que ainda restasse no interlocutor seria dirimida pelo estratagema da comparação com a economia mundial se produzisse vinho ou trigo, já manufaturados por França, Itália e Rússia. Os brasileiros deveriam preferir a borracha, o açúcar, o café, a carne, que, sendo só produtos nossos, poderiam ajudar a suprir as necessidades dos povos. Com a argumentação tão circunstanciada, escorandose em exemplo concreto, Mário desejava a conivência do destinatário: "Não acha que eu tenho razão?" E, dando um passo a mais, quer atribuir a Inojosa uma incumbência: "Mas que trabalho pesado tem de ser o nosso nesse país de expressão tão vaga, em formação ainda (...). Cansa, só de pensar. Mas seria ignóbil não pensar e seria infame e desumano não trabalhar nisso. Vamos trabalhar. Quer vir conosco?” (MORAES, 2007a, p. 136-137). 
A carta que Mário enviou em novembro de 1924 muito entusiasmou o jovem Inojosa, ainda em vinte e oito de dezembro do mesmo ano, ele a publicará no Jornal do Commercio em Recife. Como não tinha tido mais contato com Cascudo até meados de seis de janeiro de 1925, questiona se o amigo teria lido a carta de Mário que foi publicada:

Leu a carta do Mário que publiquei no 'Jornal do Commercio'? (JI, 6I-1925, apud, ARAÚJO, 2012, p. 92).

Ao que parece, Cascudo não tinha mais se inteirado do que acontecia na capital pernambucana naquele ano, possivelmente devido ao acidente de trem que sofrera em vinte e quatro de dezembro no interior do Rio Grande do Norte ${ }^{97}$. Cascudo afirmou não ter conhecimento e pediu ao amigo que lhe mandasse, pois muito lhe interessaria lê-la:

Não li a carta do Mario. E muito me interessaria fazê-lo. Olhe! Mande-m'a (CC, 12-I-1925, Id. Ibidem, p. 93).

Consultando a documentação, percebemos que embora Joaquim Inojosa tenha estado com Mário ${ }^{98}$ e outros modernistas em 1922, foi Cascudo quem primeiro se correspondeu com Mário. As evidências se colocam por intermédio da cronologia das cartas. Na última carta escrita por Mário para Cascudo no ano de 1924, ele solicitará ao amigo potiguar o envio de fotografias, de "pedaços corriqueiros do Brasil", pois tinha fome pelo Norte e como desejava saciá-la:

E agora um pedido. Tenho uma fome pelo Norte, não imagina. Mande-me umas fotografias de sua terra. Há aí obras de arte

\footnotetext{
${ }^{97}$ Cf. "Agora uma notícia. Sabe que no dia 24 [de dezembro] ia dar-lhe um assumpto explendido? Ia morrendo banalmente. Estupidamente. Nem siquer tinha lido os artigos do sr. Kalogeras no Jornal. Fui a Lajes de auto. Quebrou. Trem especial. Virou a locomotiva, espatifou-se o tender. Moralidade: machuquei um braço e fiz um discurso em Lajes onde citei Ruy, Hermes (o Fonseca), Nilo, Seabra, Artur Bernardes e outros gigantes" (CC, 5-I-1925, apud, ARAÚJO, 2012, p. 90-91).

${ }^{98} \mathrm{Na}$ primeira carta que Inojosa enviou a Mário em fevereiro de 1925 , ele finaliza pedindo "um retrato seu para a galeria dos novos do meu gabinete. Com urgência, porque o aproveitarei para um clichê na revista em que vou escrever sobre o seu livro [A escrava que não era Isaura]". Em carta breve, de quatro de março de 1925, Mário responderá ao amigo: “Aí vai o meu retrato. Vai dado com tôdo o coração além da admiração intelectual que eu tenho pelo batalhador que você é. Se fôr mesmo necessário, publique-o, como diz na sua última carta. Por mim, tenho pouca estima por êsse gênero de reclamos, confesso. Prefiro passear o meu caixadoclismo pelo seu quarto de trabalho amigamente entre imagens amigas. Principalmente a sua de carne e osso, de que nunca me esqueci" (MA, 4-III-1925, apud, INOJOSA, 1968, v.2, p. 343). Na última linha desta carta-bilhete vemos a confirmação do conhecimento prévio entre os respectivos interlocutores, iniciado no ano de 1922.
} 
coloniais? Imagens de madeira, igrejas interessantes? Conhecem-se os seus autores? Há fotografias? Acredite: tudo isso me interessa mais que a vida. Não tenha medo de mandar um retrato de tapera que seja. Ou de rio, ou de árvores comuns. São as delícias de minha vida essas fotografias de pedaços mesmos de coqueiros do Brasil. Não por sentimentalismo. Mas sei surpreender o segredo das coisas comezinhas da minha terra. E minha terra é ainda o Brasil. Não sou bairrista.

Aqui vai o meu sincero desejo de o conhecer pessoalmente (MA, 26IX-1924, apud, CASCUDO, 2010a, p. 39).

Ao tomar conhecimento da maneira como Mário tinha se referido a ele na carta enviada a Inojosa, e por ter tido do amigo paulista a confissão do desejo de lhe conhecer pessoalmente, Câmara Cascudo faz o respectivo convite ao quase Macunaíma:

\footnotetext{
Por que não se resolve a ver o Brasil que o Catete esqueceu? Inojosa em Recife e eu em Natal seríamos os hospedeiros. Venha ver estas coisas. Casas, vaqueiros, lobisomens, matutos, anedoteiros, governadores, capitães-mores, jornais - dente-de-cação, autos Fordes... venha!

E as igrejas da Bahia e Recife e Olinda... tanta coisa. E teria raiva dos frades estrangeiros que estão vendendo mosaicos, obras de talha, velhos anjinhos bochechudos, cadeiras de mogno, jacarandás para a Europa (...) (CC, 19-V-1925, apud, CASCUDO, 2010a, p. 40-41) ${ }^{99}$.
}

Sobre estes últimos aspectos, percebemos que em virtude da precariedade de espaços institucionalizados, as relações entre os intelectuais no Brasil mostravam-se especialmente sensíveis ao contato pessoal. A carta, com seu registro ambíguo em que se misturam informações técnicas, julgamentos críticos e vida pessoal, eram especialmente talhadas para essa tarefa. A todo o momento, era preciso ter e dar provas de amizade e consideração. Isso fica mais evidente no caso dos jovens intelectuais Cascudo e Inojosa, que estavam em busca de inserção nas redes de sociabilidade

\footnotetext{
${ }^{99}$ Em carta de trinta de dezembro de 1925, Cascudo voltou a insistir no projeto: (...) "Vamos ao nosso plano. O Inojosa quer convidá-lo pra Recifar (de Recife). Eu em abril volto pra lá. Já devo ter conversado com V. por cartas. Ajustamos tudo e V. aproveita as férias (que são minhas também) e vem descansar aqui. Pense nisto. Uma hora de prosa no Recife. Três ou quatro dias lá. Algum dinheiro para nivelar a despesa de hotel e voa comigo para aqui. (...) Perdoe, meu amigo, esta ideia de dinheiro e passagem. Significa somente o grande desejo que eu tenho de vê-lo perto de mim e à distância de um abraço". (CC, 30-XII-1925, apud, CASCUDO, 2010a, p. 83).
} 
modernistas por intermédio de Mário de Andrade. Como no modo contrário, quando Mário procura conhecer as particularidades culturais do Nordeste por intermédio deles (GUIMARÃES \& ARAÚJO, 2004, p. 104-105). A correspondência de amizade intelectual permitiu a Mário, Cascudo e Inojosa uma aproximação com circuitos informais de sociabilidade e que evocaria sentimentos, além de troca de favores. Em todos os casos, a amizade e o debate intelectual são, ao mesmo tempo, condição e produto do trabalho entre os correspondentes (GOMES, 2004, p. 54-55).

Na primeira carta que Inojosa enviou a Mário, ele agradece pela carinhosa e estimulante carta. Informa-o que a teria publicado no Jornal do Commercio com o título em duas colunas "Arte brasileira”, tendo causado uma boa impressão na cena recifense. Comenta sobre o convite para trabalhar com os modernistas paulistas, e diz que não tinha feito outra coisa, senão divulgar os nomes de Mário, Oswald, Tarsila, Serge Milliet, Rubens de Moraes, Menotti e outros. Dizia ainda que seu opúsculo teria causado muitas polêmicas literárias e que o nome Mário de Andrade, como o dos outros amigos modernistas, "eram jogados como explosivos em campos inimigos":

Recebi, faz algumas semanas, a carinhosa carta que v. me escreveu agradecendo 'A Arte Moderna'. Fiz-la publicar no 'Jornal do Commercio', com o título em duas colunas - 'Arte brasileira'. No meio intelectual daqui causou a melhor impressão; e muita gente que, sistematicamente o combate, o aplaudiu.

Convidou-me v. para trabalhar com os de São Paulo. E o que venho fazendo, meu caro, senão isso? Devido ao meu esforço, a minha atividade, todos os novos de São Paulo são conhecido em Pernambuco: e a minha ação se distende pela Parahiba e Pará - que no Rio Grande do Norte existe o espírito ‘rapidíssimo’ do nosso Cascudo. Certo que, nesta campanha muitas pedradas ei recebido, causando-me o continuar com a amizade e a lembrança de vocês. Mário de Andrade, Rubens de Moraes, Oswald de Andrade, Tarsila do Amaral, Serge Milliet, etc., o Recife os não conhecia em 1923 quando voltei do Rio. Proclamei a excelência do que produziram; e, para despertar a curiosidade do meio, chamei-os de futuristas, originaes, inovadores, únicos no gênero...

(...)

A 'Arte Moderna' motivou polêmicas literárias de (sic.): o seu nome, como os dos outros, eram jogados como explosivos em campos inimigos (JI, II-1925). 
Nesta carta de Inojosa escrita em fevereiro de 1925, e em mais duas outras que ele enviou para Mário - uma em trinta de março de 1925 e outra de dois de outubro de 1926 -, não existe réplica quanto ao assunto "abrasileiramento do brasileiro" esboçado por Mário na missiva de vinte e oito de novembro de 1924, e sim informes sobre a divulgação do Modernismo e da Arte Moderna. Lendo essas cartas de Inojosa, percebemos que sua ação no movimento tinha um caráter de divulgação, com forte conotação militante, aspecto que se sobrepunha, portanto, a uma discussão a fundo sobre as grandes questões do momento (ARAÚJO, 2012, p. 66) ${ }^{100}$ :

Pois então pensa que sou capaz de esquecer-me a qualquer um de vocês, meus dedicados amigos, admiráveis corneteiros do espírito moderno no Brasil inteiro? Perdoo-lhe muitas cousas como o escrever-me raramente mas não lhe perdoo tal pensamento, porque as figuras do grupo paulistano eu as evoco dia a dia, espalhando o quanto posso as notícias dos seus triunfos por estas plagas nortistas (JI, 2-X1926).

Segundo Moraes (2007a), aquela ideia tão divulgada por Mário de Andrade entre seus colegas de geração permaneceu no ar e, ao ser acolhida, chegou até o esfumaçamento da autoria. Em de junho de 1925, um grupo de escritores - passadistas e modernistas - oferecia um "banquete" a Graça Aranha que, em 1924, havia se desligado rumorosamente da Academia Brasileira de Letras. O discurso do homenageado aparece posteriormente no Correio da Manhã carioca, texto de que Mário de Andrade toma conhecimento no recorte "Uma Festa das Letras", recebido de Manuel Bandeira. Na fala do autor de Espírito Moderno, alguma identidade de pensamento. Graça Aranha, batendo sempre na tecla do "objetivismo dinâmico" e da "perpétua alegria", invoca a

\footnotetext{
${ }^{100}$ Ao comentar com Cascudo em carta de primeiro de janeiro de 1926 sobre a cena intelectual de Recife, Mário tece os seguintes comentários sobre suas impressões a respeito de Joaquim Inojosa: (...) "E sobretudo me parece gente sem sensibilidade nova, sem essa agilidade intelectual desabusada que é tão característica do nosso tempo e que você [Cascudo] tem. O próprio Inojosa que conheço um pouco mais me parece inteligente, é incontestável, aproveitável, muito trabalhador mas... mas falta a tal coisa de não só saber porém sentir sem querer, inconsistentemente: sentir. E, é lógico, agir por essa sensibilidade. Me reserve esta opinião dentro de você. Pode ser falsa, devido ao conhecimento falho ou mesmo sendo verdadeira, não adianta nada. (...) Acho mesmo que a sensibilidade independe da gente. É verdade que uma boa vontade, aspiração grande de compreender faz muita coisa até na sensibilidade da gente porém sobretudo sobre o ponto de vista da compreensão. Sobre o ponto de vista da criação não. (...) Eu tenho por isso, muita esperança nessa gente do Norte; mais dia menos dia de tanto ouvir e de tanto matutar hão de ficar em dia com o tempo, você vai ver. O diabo é que também talvez então o tempo já esteja se modificando!... Diabo de pressa!” (MA, 1-I-1926, apud, CASCUDO, 2010a, p. 85).
} 
contribuição do Modernismo na atualização mental do Brasil e conclama uma conjunção de forças construtivas aparelhadas pelo "senso real" para realizar a ascensão do nacional ao universal, que "nos transformará de imitadores a criadores universais". Nesta carta que Mário escreve a Bandeira, considerando a coincidência de visão programática que encontrava no artigo, defende a primazia da descoberta, afiançando ao amigo que Graça Aranha "descobriu a mesma coisa que eu porque não lembro de ter falado pra ele ou pra mesa sobre essa de que só sendo brasileiro que nos universalizaremos. Essa idéia é minha já faz tempo". Cabia-lhe, então, apresentar provas e, para tanto, chamou a próprio testemunho a carta que enviara, em 1924, a Inojosa (MORAES, 2007a, p. 138):

Quanto ao do Graça [discurso], creio que ele descobriu a mesma coisa que eu porque não me lembro de ter falado pra ele ou pra mesa sobre essa de que só sendo brasileiro que nos universalizaremos. Essa idéia é minha já faz tempo. Mais explicitamente já tenho dito isso em discussão epistolar com os mineiros e os nortistas. Não sei se já disse pra você. Sei que o Inojosa de Pernambuco publicou no Jornal do Commercio de lá uma carta minha em que eu falava sobre isso. Minha idéia exata é que só sendo brasileiros isto é adquirindo uma personalidade racial e patriótica (sentido físico) brasileira que nos universalizaremos, pois que então concorremos com um contigente novo, novo assemblage de caracteres psíquicos pro enriquecimento do universal humano. Isto aqui está dito meio complicadamente. $\mathrm{Na}$ tal carta está melhor. Vou mandar buscá-la (MA, 24-VI-1925, apud, MORAES, 2001, p. 218).

Escrevendo mais uma vez a Inojosa, Mário diria em carta não datada, mas possivelmente escrita entre meados de final de junho e início de julho de 1925, que esperava que o amigo, fosse capaz de lhe fazer um favor, coisa simples: lembra que o crítico pernambucano teria publicado a carta onde falava sobre suas ideias nacionalistas, tinha grande necessidade do envio do jornal com a publicação, pois teria necessidade de provar que não necessitava plagiar ninguém, as ideias eram suas:

Você era capaz de me fazer um grande favor de amigo? Sei que é e não tem nada de difícil o favor. Isto: você publicou aí uma carta que eu mandei pra você sôbre o seu livro e minhas idéias nacionalistas. Tôda ou pedaço não sei porém de qualquer forma serve. Você podia 
me mandar o jornal onde foi isso publicado? Tenho grande necessidade disso por causa diuma coincidência de idéias por aqui e pra provar que não plagiei ninguém. Será pois um favor que agradeço com a mão na sua. Como vai e como vão os companheiros d'aí? É possível que você tenha lido umas bisbilhotices de jornais cariocas sôbre uma separação do movimento paulista moderno do do Rio. É mentira. Estão se aproveitando duma briga que houve entre o Osvaldo e o Graça pra fazer escândalo. Não houve separação. Houve uma gentinha susceptível que andou se irritando e dizendo coisas. Já reina paz em Varsóvia outra vez. Briguinhas-de-comadres dum ridículo de chorar de rir. Mais nada (MA, s./d., apud, INOJOSA, 1968, v. 2, p. $341-342)^{101}$.

Ao que parece, esta situação não terminou em "brigas de comadre", o próprio Mário irá se queixar a Cascudo em carta de três de fevereiro de 1926, ao comentar que Graça Aranha andava fazendo umas coisas "inconfessáveis, de politiquices literárias, atacando os que não se sujeitavam a canga dele, e o que é pior, atacando só por indiretas"; tinha chegado inclusive a usar o nome de Mário de Andrade para afastar Oswald da revista Estética:

\begin{abstract}
Menos susto deve causar em você a minha 'Carta aberta a Graça Aranha'. Também trabalho de higiene. Não nego o valor de Graça nem o papel de protetor nosso e os benefícios pra nós que disso derivam, porém o Graça anda fazendo um poder de coisas inconfessáveis, de politiquices literárias, atacando os que não se sujeitavam à canga dele e o que é pior, atacando só por indiretas. Chegou a ponto de se servir do meu nome sem a autorização pra afastar o Osvaldo que ele sabe que é meu amigo pessoal da revista Estética. Fiquei indignado como você bem há de imaginar e mandei aviso pra ele que não era solidário com ele porém com o movimento que ele não podia representar sozinho. Vai ele deu pra jeremias e andou se queixando pra quem queria escutar que os modernistas
\end{abstract}

\footnotetext{
${ }^{101} \mathrm{Na}$ nota que Inojosa interpõe a respectiva transcrição (ver nota 76, Cf. INOJOSA, 1968, v. 2, p. 342), comentando sobre os eventos que contextualizam a compreensão da carta, não faz alusão ao envio. Entretanto, o crítico pernambucano, em carta enviada a Mário, no dia trinta de março de 1925, comentava que remeteria ao amigo paulista alguns exemplares do Jornal do Commercio, na esperança de animá-lo para possível colaboração: "Vou enviar-lhe alguns exemplares do 'Jornal do Commercio', do qual sou um dos redatores, porque talvez você se anime a escrever alguma colaboração para eles” (JI, 30-III-1925). O convite parece ter surtido efeito, pois, Mário de Andrade publicou no respectivo jornal em vinte e quatro de maio de 1925, um artigo com o título, Modernismo e Ação (Cf. AZEVEDO, 1996, p. 225-227).
} 
ingratos de S. Paulo tinham se afastado dele apesar do que ele tinha feito por nós (...) (MA, 3-II-1926, apud, CASCUDO, 2010a, p. 88).

Sobre a "Carta aberta ao Graça Aranha", Cascudo comentará que Mário não viesse a pensar que venceria o sr. Aranha, ele era invencível, pois ele "é invencível não tem ideias próprias. Toda gente encontra no sr. Graça um traço seu. Espelho retrato do último que o olhou" (CC, 9-III-1926, Id. Ibidem, p. 94). Em carta enviada a Joaquim Inojosa, vemos Cascudo questionar a prioridade do Graça Aranha no movimento modernista e reiterar a supremacia de Mário frente a Semana de Arte Moderna: (...) "Eu de mim, discordo com a prioridade do Graça no movimento. Já V. estava fazendo reacção. Os paulistas tinha feito a Semana de Arte Moderna. Havia a Paulicéa do Mário...O Graça tornou o movimento coletivo. Não acha V.?” (CC, 8-III-1925, apud, ARAÚJO, 2012, p. 98). Se olharmos os artigos publicados em jornais por Cascudo (24VIII-1924) e Inojosa (20-VIII-1924) na época, veremos que os dois escreveram artigos sobre Graça Aranha, e parece que tinham opiniões antagônicas sobre o assunto. Cascudo, discordando, chegou a afirmar que:

Suponha que o sr. Graça Aranha perguntasse a minha opinião. Não perguntaria. Mas, enfim, suponhamos que o fizesse. Eu, fingindo não ver, ia dizendo por aqui:

Este movimento de arte moderna no Brasil é simplesmente admirável. Pregam tudo e nada explicam. Não há um só trabalho demonstrando a viabilidade artística desse credo. Se alguém, como eu pretende conhece-lo, foi a custa de muito livro francês e muita tolice italiana.

(...)

(...) O primeiro dever de uma literatura tal qual deseja o sr. Graça Aranha é um país incolor. Um país-maria-vai-te-com-as-outras.

(...)

O Modernismo, o verdadeiro como eu tenho feito, é ser independente; nunca achei livro bem escrito por que Ruy Barbosa achava. Nunca encontrei graça nos lábios convencionalmente alegres (CASCUDO, 1924, apud, ARAÚJO, 1995, p. 109-110).

Já Joaquim Inojosa se colocava como favorável aos posicionamentos de Graça Aranha: 
Êsse caso da conferência de Graça Aranha na Academia Brasileira de Letras, que tantas discussões tem suscitado no Brasil inteiro, e que pôs em polvorosa o formigueiro da nossa intelectualidade, sugere-nos algumas palavras sôbre o autor revolucionário da 'Estética da Vida'. Graça Aranha representa, para nós, o exemplo excepcional, bem raro, do escritor que, ausentando-se de sua pátria por longos anos, não deixa de exercer influência sôbre sua mentalidade.

(...)

A conferência que, numa vibração de audácia necessária, realizou na Academia Brasileira de Letras sôbre o 'Espírito Moderno', resume os arroubos espirituais da mocidade brasileira, que deseja uma inteligência criadora, inimiga da triste imitação das coisas estrangeiras.

Que fizeram, até hoje, os homens de letras do Brasil? (INOJOSA, 1968 , v. 2 , p. $53 ; 55)$.

Em carta de vinte e um de abril de 1926, Mário encerraria o debate em torno de Graça Aranha, informando a Cascudo que:

Quanto ao Graça aranha continuo aliás a admirar o graça como admirava dantes. $\mathrm{O}$ que fiz foi acabar com as intrigas que ele estava fazendo. Parece que parou e está convencido que não pode representar o papel de pai-de-todos no nosso movimento coletivo mas sem chefe (MA, 21-IV-1926, apud, CASCUDO, 2010a, p. 100).

Concluindo este capítulo, tomamos como fechamento uma das proposições de Angela de Castro Gomes (2004) que demonstrou que o convívio entre intelectuais, como a leitura, é fundamental para o desenvolvimento de ideias e sensibilidades. Para escrever, pintar, compor, etc., o intelectual precisa estar envolvido em um circuito de sociabilidade que, ao mesmo tempo, o situe no mundo cultural e lhe permita interpretar o mundo político e social de seu tempo. Nesse sentido, vemos que a correspondência de Cascudo, Mário e Inojosa, analisada de forma serial e intercalada, nos deu a possibilidade de comprovar essa rede de auxílio mútuo entre os missivistas. Por isso, afirma-se que não é tanto a condição de intelectual que desencadeia uma estratégia de sociabilidade e sim, ao contrário, a participação numa rede de contatos que demarca a específica inserção de um intelectual no mundo cultural. 
Desse modo, avulta em importância a troca de correspondência, pois ela pode abarcar tanto os intelectuais reconhecidos como sociáveis quanto aqueles cuja preferência é a vida mais reclusa dos gabinetes de estudo e pesquisa. As cartas são, pois, uma prática de escrita que integra a produção de textos de muitos intelectuais, especialmente aqueles que viveram até meados do século $\mathrm{XX}$, como é o caso dos aqui selecionados em nossa análise. A correspondência pessoal entre intelectuais é, sobretudo nesses casos, um espaço revelador de suas ideias, projetos, opiniões, interesses e sentimentos. Uma escrita de si que constitui e reconstitui suas identidades pessoais e profissionais no decurso da troca de cartas (GOMES, 2004, p. 51-52). 


\title{
5. Capítulo IV:
}

\section{MEMÓRIAS DO MOVIMENTO MODERNISTA EM PERNAMBUCO (E ADJACÊNCIAS):}

a correspondência de Joaquim Inojosa com José Américo de Almeida e

\author{
Luís da Câmara Cascudo
}

\begin{abstract}
Não é intuito do autor dêste livro fazer a crítica literária do movimento modernista realizado em Pernambuco. Mesmo porque lhe coube permitam a imodéstia - desencadeá-lo e dirigi-lo, sob a inspiração e o incentivo dos 'klaxistas' da Semana de Arte Moderna de São Paulo. Limitar-se-á a relatá-lo, para que se não perca, pela inclemência do tempo ou propósitos suspeitos, a notícia de um acontecimento que o
\end{abstract} A. considera decisivo na vida intelectual do seu Estado (INOJOSA, 1968, v. 1 p. 31$)$.

5.1. O Movimento Modernista em Pernambuco de Joaquim Inojosa: um livro como lugar de memória ${ }^{102}$

O registro histórico da correspondência de Joaquim Inojosa com José Américo de Almeida e Luís da Câmara Cascudo aparece pela primeira vez em O Movimento Modernista em Pernambuco (1968-1969) (duas cartas de José Américo de Almeida, décadas de 20; e treze cartas de Luís da Câmara Cascudo, conforme observamos anteriormente); o segundo registro das cartas de Almeida, foi em José Américo de Almeida - Algumas Cartas (1980) (3 cartas da década de 20 - sendo duas já publicadas e uma inédita - e 18 escritas entre a década de 60 e 70). Os escritores ocupam lugar sui generis neste capítulo por serem dois dos primeiros entusiastas que escreveram para Inojosa, falando das impressões e impactos causados pela carta manifesto A Arte Moderna (INOJOSA, 1984, p. 42-44):

\footnotetext{
${ }^{102}$ De acordo com Barros (2012), é possível perceber no Movimento Modernista em Pernambuco (19681969), um significativo "lugar de memória", sendo, pois, campo de construção de genealogias, representações e inscrições do intelectual Inojosa na história do modernismo (BARROS, 2012, p. 118). Os "lugares de memória", conforme conceituou Pierre Nora (1993), nascem e vivem do sentimento, portanto, não existe memória espontânea, logo, é preciso para sua "preservação" criar arquivos, organizar celebrações, pronunciar elogios fúnebres, notariar atas, porque essas operações não são naturais (NORA, 1993, p. 13).
} 
Ahi vai o registo de tua 'Arte Moderna'. Ainda estou em tempo de felicitar-te pelo escândalo (CC, 22-VIII-1924, apud, ARAÚJO, 2012, p. 87)

Recebi A ARTE MODERNA, que é mais uma expressão de seu talento e de sua cultura. (...) Não sou infenso ao espírito novo. Compreendo a necessidade de subordinar a arte às outras formas de vida que as conquistas do progresso vão impondo. Penso, porém, que para ampliar essa tendência não é preciso destruir o patrimônio da inteligência cosmopolita. É arriscado conjurar, de uma vez, as fórmulas consagradas. Daí as demasias das reações que resultam ridículas. (...) (JAA, 8-VIII-24, apud, INOJOSA, 1984, p.42).

Os originais das cartas publicadas de José Américo de Almeida, além de outras inéditas, pertencem à Fundação Casa de Rui Barbosa, localizada no Rio de Janeiro, como parte do Arquivo Museu de Literatura Brasileira, formando a "Coleção Joaquim Inojosa, séries: correspondência pessoal", documentos que foram doados pelo titular em testamento. As cartas de Inojosa emitidas a José Américo de Almeida se encontram na Fundação Casa de José Américo de Almeida, localizada em João Pessoa: dezoito cartas escritas a partir de 1966 até meados de 1977, todas elas datilografadas em papel timbrado com a logomarca do escritório de advocacia de Inojosa e assinadas por ele, parecem encontrar-se até o presente momento, inéditas - não conseguimos encontrar nenhum outro estudo que fizesse menção a esse conjunto de documentos.

A pesquisa de Araújo (2012) localizou nesse mesmo acervo e no Ludovicus Instituto Câmara Cascudo, na cidade de Natal, a correspondência de Inojosa estabelecida com o escritor potiguar, contabilizando um total de sessenta e seis documentos trocados entre Cascudo e Inojosa, entre cartas e cartões-postais, que formam dois grandes blocos de correspondências. O primeiro é composto de cartas trocadas ao longo dos anos de 1920, no auge da divulgação do movimento modernista brasileiro, analisados no capítulo anterior. O segundo (documentos que aqui iremos analisar), por sua vez, é composto de cartas trocadas entre os anos de 1968 e 1984, o período em que os dois missivistas publicaram livros relacionados à memória daquele movimento (ARAÚJO, 2012, p. 37-38).

Chama a atenção, de início, a interrupção do envio e recebimento de cartas, de ambos os missivistas, em um longo período (de 1928 a 1966, com José Américo; e de 1926 a 1968, com Cascudo). Esse lapso de trinta e oito e quarenta e dois anos apresentou-se como intrigante para a pesquisa, uma vez que nele os três amigos 
continuaram exercendo a atividade intelectual em meio a profundas mudanças na conjuntura nacional. A interrupção da correspondência, no final dos anos 1920, ocorreu devido ao termino das atividades de Joaquim Inojosa como divulgador do Modernismo no Nordeste, coincidindo com sua mudança para o Rio de Janeiro. Sobre o fato, comentou Neroaldo Pontes de Azevedo (1996):

Entre meados de 1927 e o ano de 1930, quando se transfere para o Rio, perseguido por ter tomado parte nos acontecimentos de Princesa, Joaquim Inojosa praticamente não aparece nos jornais e revistas de Recife. Pode-se afirmar que a campanha modernista, por ele empreendida, estava terminada (AZEVEDO, 1996, p. 94).

No prefácio de José Américo de Almeida - Algumas Cartas (1980), Inojosa reforça nossa linha de raciocínio:

As cartas que se vão ler - 3 da década de 20 e 18 de quarenta anos depois: outras, da $1^{\text {a }}$ fase, desapareceram nos transtornos da mudança do Recife para o Rio logo após a Revolução de 1930 -, revelam duas admiráveis facetas da invulgar personalidade de José Américo de Almeida: a de escritor e a do amigo.

(...)

Note-se que em 1930 nos havíamos separado politicamente, o que, entanto, em nada alterou os sentimentos de pura amizade renovados no reencontro de 1966 - reinício da correspondência -, bem definidos nos termos da oferta de um exemplar do romance A Bagaceira ( $3^{\mathrm{a}}$ edição, de 1928):

“Ao grandíssimo amigo Inojosa, com a admiração que vem de longe. José Américo Rio, 14-7-973” (INOJOSA, 1980, p. 17-18).

No livro de memória Na Ronda do Tempo (1998b), Cascudo também registra a longa distância e ausência do velho amigo:

Abraço um amigo de 45 anos, Joaquim Inojosa, leader do 'Movimento Modernista em Pernambuco', que expôs e documentou em 700 páginas ágeis (dois tomos, 1968). Alegria de reviver meu tempo de 'Acadêmico de Direito' no Recife, e a fase ainda juvenil da agitação literária, clímax com a vinda de Guilherme Almeida lendo o Raça (CASCUDO, 1998b, p. 41). 
Conforme já vimos no capítulo anterior, entre os anos de 1968 e 1969, Inojosa reuniu na forma de livro uma farta documentação composta de matéria de jornais, cartas, trechos de livros, fotografias e depoimentos sobre o modernismo. A obra o Movimento Modernista em Pernambuco compõe uma coleção de três volumes contendo um arquivo documental dedicado à geração de sua mocidade.

Inojosa quis acreditar que a publicação do conjunto de documentos e sua narrativa introdutória, dividida em tópicos intitulados "roteiro", "senha", "desafio", "adesões", “colaboradores", "repercussão", não constitui uma crítica do movimento. Reveste-se de modéstia e representa-se como relator de uma notícia, mas logo em seguida perde-a ao instituir o movimento que desencadeou e dirigiu como o acontecimento decisivo na vida intelectual de seu estado. Seu propósito é combater a inclemência do tempo ou propósitos suspeitos. As narrativas davam conta da importância do movimento regionalista e da atuação de Gilberto Freyre na década de 1920, sendo estes os propósitos suspeitos combatidos pelo autor (BARROS, 2012, p. 119; INOJOSA, 1968, v. 1 p. 31).

O Movimento Modernista em Pernambuco constitui um apego visceral a um momento histórico, mantendo um grupo de intelectuais como devedores do passado que engendraram e que os engendrou. Pode-se afirmar ainda que a respectiva obra é um trabalho de "enquadramento da memória", realizado através da seleção, celebração e eternização de determinados feitos e fatos colecionados que são alçados à categoria de "prova" da veracidade do seu relato; alimentam e forjam de forma subjetiva e intencional a construção de imagem positiva de Inojosa, consolidando seu reconhecimento e legado pessoal pelas gerações seguintes (BARROS, 2012, p. 120).

Desse modo, vale o questionamento sobre que desejo de memória e história atravessaria a publicação da respectiva obra? Natália Barros (2012) nos mostra que o "Inojosa narrador" de sua história parece querer narrar na tentativa de assegurar a continuidade dos tempos históricos; para manter-se vivo nas narrativas de si e dos outros. Nesse sentido, a obra se põe como lugar de memória, ou seja, criação não espontânea, portadora de sinais de reconhecimento e de pertencimento desse individuo, construído por meio de um diversificado conjunto de ações diretamente ligadas à escrita de si e à constituição de uma memória de si, pois acompanhar a produção da memória de Joaquim Inojosa representa caminhar entre discursos, práticas, representações e temporalidades variadas (BARROS, 2012, p. 27; 31-38; NORA, 1993, p. 13). 
Quando publicou seus textos sobre o movimento modernista, o autor tentou afastar os interesses particulares, escondeu seu desejo de autopromoção, deslocando o empreendimento para o campo da justiça da memória dos participantes dos acontecimentos da década de vinte (BARROS, 2012, p. 115-116):

Para que não desapareçam os vestígios dos participantes da mocidade pernambucana em tão importante movimento, ponto de partida do Brasil de hoje, é que escrevo este livro.

(...)

Publicando-o nada reivindico para mim. As ideias modernistas, estou certo, atingiriam Pernambuco de qualquer forma, e eu apenas as teria antecipado, pela coincidência de contatos com o grupo de São Paulo em 1922 (INOJOSA, 1968, v.1, p. 32).

Sobre este aspecto, concordamos com Barros (2012), quando propõe que é preciso termos como horizonte o caráter autobiográfico das publicações sobre o modernismo realizadas por Inojosa e desconfiarmos da coerência de seu relato, da sequência de acontecimentos com significado e direção aparentemente lineares; para que não nos conformemos com a ilusão retórica do nosso personagem/autor/narrador e, principalmente, inserirmos estes escritos como uma estratégica de busca de uma autoestima intelectual e afetiva (BARROS, 2012, p. 116-117).

O Movimento Modernista em Pernambuco (1968-1969) será aqui tratado apenas nos aspectos em que corroboram para a articulação dos seus arquivos da criação, intercalado pela rede de sociabilidade intelectual estabelecida através de sua correspondência com José Américo de Almeida e Luís da Câmara Cascudo; no que compete à tentativa de Inojosa estabelecer para si o seu lugar na memória no modernismo em Pernambuco; como no que diz respeito ao seu embate com Freyre, que tentou minimizar sua atuação e influência no respectivo campo literário ${ }^{103}$; e da acusação de falseamento do processo de publicação e divulgação do Manifesto Regionalista interposta ao sociólogo de Casa Grande \& Senzala. Estes últimos aspectos

\footnotetext{
${ }^{103}$ Na obra Região e Tradição (1968) Freyre fez a respectiva afirmação: "Parece que nenhuma das duas influências [o regionalismo-tradicionalista e o modernismo] se verificou de modo decisivo sôbre a gente do Nordeste, a não ser e casos quase individuais ou isolados: o do sr. Joaquim Inojosa, por exemplo, por algum tempo discípulo intransigente, no Recife, de 'modernistas' do Sul; discípulo amado do então, como hoje, meio apostólico sr. Mário de Andrade - o extraordinário poeta do Noturno de Belo Horizonte e crítico de Castro Alves, que será lembrado na história literária do Brasil não só por essas suas sólidas virtudes como pelos seus brilhos de General Booth do "modernismo de 1922" (FREYRE, 1968, p. 60). É a partir de então que se iniciará "a cruzada" de Inojosa, contra o regionalismo tradicionalista freyreano.
} 
se desdobraram num conjunto de outras obras de Joaquim Inojosa tais como: No Pomar Vizinho... (1968b), Carro Alegórico: nova resposta a Gilberto Freyre (1973); Pá de Cal (1978) ${ }^{104}$; que serão abordadas e discutidas com maior ênfase na correspondência que irá estabelecer com Cascudo no decorrer de 1968 a $1984{ }^{105}$, conforme veremos no decorrer deste capítulo.

Para compreendermos a reaproximação entre Inojosa e Zé Américo ${ }^{106}$, devemos destacar que em 1967, José Américo de Almeida tornou-se imortal da Academia Brasileira de Letras ${ }^{107}$ e em 1976, foi eleito o Intelectual do Ano pela União Brasileira de Escritores, seção São Paulo. Em carta de vinte de setembro de 1976, Joaquim Inojosa, ocupante de uma cadeira na Academia Carioca de Letras, vice-presidente da Ordem dos Velhos Jornalistas, diretor secretário do Sindicato dos Escritores da Guanabara, expressa ao amigo sua aspiração de concorrer a uma vaga na Academia Brasileira de Letras e pede apoio e voto (BARROS, 2012, p. 223):

- Não vivo pensando em vaga na Academia, mas diante da contingência humana, na primeira que houver, serei candidato (JI, 20IX-1976).

Os esforços autobiográficos de Joaquim Inojosa realizados na década de 1960 e 1970, seus usos do movimento modernista, possivelmente, tinham um alvo definido: tornar-se acadêmico imortal. A resposta de José Américo em 1976, certamente, foi um motor para seus ideais, mas que de todo o desencorajava ao intento, pois, desejava que sua opção não fosse considerada um motivo particular (BARROS, 2012, p. 223):

\footnotetext{
${ }^{104}$ Esta crítica também se estenderá a Sursum Corda! (1981) mas como a obra não é abordada no corpo das correspondências aqui em análise, optamos por apenas mencioná-la em nota para maiores informações (Cf. INOJOSA, 1981).

${ }^{105}$ Faremos aqui uma ressalva de que não nos ateremos a analisar todo o conjunto desta correspondência, nos concentrando apenas àquelas que nos dá oportunidade de problematizar as questões referentes aos objetivos propostos para a elaboração deste capítulo.

${ }^{106}$ Em carta de dezessete de novembro de 1967, José Américo de Almeida comentaria sobre um projeto de Inojosa: "Você quer dar ao meu romance uma outra vida. Essa apresentação seria seu maior sucesso. Isso, porém, deve ser trabalhoso". (JAA, 17-XI-1967, apud, INOJOSA, 1980, p. 31). Em nota o autor de A Arte Moderna, explicou que se tratava do Centro Cultural do Nordeste, que teria José Américo, como presidente de honra. O romance A Bagaceira deveria sair em edição de luxo, e os direitos autorais, seriam concedidos ao centro. O projeto não chegou a ser iniciado. Entretanto, a passagem, é valida para se compreender o grau de reaproximação em que os dois autores se encontravam no período.

107 Em carta de quinze de novembro de 1966, José Américo agradece a publicação de um artigo de Inojosa em $O$ Jornal, Rio de Janeiro no dia 18 de outubro de 1966 no momento de sua candidatura à Academia Brasileira de Letras: "Logo que saiu aqui seu artigo a respeito de minha candidatura à Academia, tive pressa em escrever-lhe agradecendo essa sua contribuição, das mais relevantes, para o efeito moral de minha vitória. Não ignora como sei medir o seu valor. Apreciei o seu trabalho não só por esse cunho de autoridade, como pela força da análise e oportunidades dos argumentos". (JAA, 15-XI1966, Id. Ibidem, p. 29).
} 
Recebi sua carta. É muito legítima sua aspiração, quando não fosse por suas credenciais de escritor pela parte que tomou no Movimento Modernista. Assim não lhe faltam títulos para entrar na Academia.

Apesar de estar comprometido com outros nomes, no caso de vaga saberia explicar como me acho obrigado a apoiá-lo. No entanto, não gostaria de dar um voto perdido. Na oportunidade, consiga uma base, um número razoável de compromissos pessoais, que não lhe faltarei. Quero avisá-lo de que às vezes se formam, quando menos se espera, correntes invencíveis.

Não quer dizer que eu siga o critério das maiorias. O que desejo é que minha opção deixe de ser considerada um motivo particular, afrontando o espírito dominante (JAA, 10-10-1976, apud, INOJOSA, 1980, p. 46).

Nove dias depois, agradecendo o conforto do amigo, pede para que o mesmo ficasse tranquilo, pois só entraria na aventura caso achasse que tinha "alguns votos a conquistar na luta", fora disto, continuaria a observar; o fato é que só pensara sobre isso porque o Menotti parecia não estar satisfeito com sua ausência do "consagrado grêmio", mas só entraria na raia caso julgasse ser merecedor, embora pensasse que nunca conseguiria. Continuaria dando seu recado, no jornal e no livro, modesto, mas constante. No entanto, sugere que a academia que se cuidasse, do contrário em tempo próximo, escritor algum lhe bateria as portas:

Muito obrigado. Sobretudo pelo conforto de considerar que mereço tanto.

Pode ficar tranquilo. Não entrarei em aventura. Serei candidato se conseguir um razoável ponto de partida, que, com alguns votos a conquistar na luta, possa completar o necessário para a vitória ou a quase vitória.

Fora disto, continuarei a observar. Sou constantemente cutucado pelo amigo Menotti, que não parece conformar-se com a minha ausência do consagrado grêmio.

Entanto, a minha aspiração estará sempre sujeita ao que V. chama de ‘correntes invencíveis'. Logo, não sei se ela se concretizará na $1^{\mathrm{a}}$ ou $2^{\mathrm{a}}$ vaga ou nunca. (...)

(...) 
Pode ficar tranquilo, repito, meu prezado amigo. Só entrarei na raia se julgar que tenha chegado a minha vez. Talvez não chegue nunca, o que não me desestimula a continuar dando o meu recado, no jornal e no livro, modesto mas constante.

(...)

A Academia que se cuide, do contrário dentro de algum tempo escritor de categoria alguma lhe baterá às portas... (JI, 19-10-1976).

Neste último aspecto aqui apresentado, observamos um Inojosa diferente daquele que na juventude conclamava a mocidade a mirar e seguir os exemplos de Graça Aranha bradando que o "academismo é um mal (...) não se pode oficializar a arte. A imaginação do artista há de ser livre para criar". Que não induziria a outra meta "a inteligência superior de Graça Aranha" (INOJOSA, 1968, v.2, p. 55). Por que razão almejava neste momento adentrar para a Academia Brasileira de Letras? Talvez, sua nova forma de pensar sobre Graça Aranha e sobre o papel da Academia de Letras tenha mudado. Como escrevera pela aclamação de José Américo para se tornar um imortal, deve noutro momento ter lido, ou ouvido a palestra proferida pelo autor de A Bagaceira, intitulada Graça Aranha - o doutrinador (1968); nela, não negava a influência de Graça frente à Semana de Arte moderna, todavia, não concordava que a Academia fosse espaço para conservadorismo em arte, sendo feitas as seguintes considerações:

Desde 1922, [Graça Aranha] tomara uma posição de vanguarda, ao lado dos moços que tinham declarado guerra à velha literatura. Seu papel, na Semana da Arte Moderna, em São Paulo, importara na rutura com todos os compromissos do passado, sem querer saber se essa atitude era ou não coerente. A Academia era a mais visada e, como acadêmico, já se sentia deslocado e impaciente, sorvendo o sôpro renovador, como uma aura de libertação.

(...)

A Academia, nessa etapa, poderia pecar pela inércia, pela demora em ultrapassar a rotina, mas não padecia de nenhuma rigidez, de formas tradicionais compulsórias.

(...)

Não era um círculo fechado em que a velha guarda pudesse condenar indesejáveis; acolhia até boêmios e assim se reformava absorvendo influências estranhas com uma variedade que se opunha a certos padrões. Em vez de assimilar correntes reflexas, estimulava a 
participação direta. Era êsse o seu progresso (ALMEIDA, 1968, p. 1213).

Pelo sim, pelo não, Joaquim Inojosa, parecia continuar vendo Graça Aranha do mesmo modo que o fazia em sua juventude. No artigo "Graça Aranha, um renovador?", ao tratar sobre o centenário do autor do Espírito Moderno, que havia sido comemorado em vinte e seis de junho de 1968, ele dispõe toda a crítica exposta até aquele momento sobre a influência ou não do Graça para a Semana de Arte Moderna, dentre esses, destacavam-se: José Veríssimo, Prudente de Morais Neto, sob pseudônimo (Pedro Dantas), Oswald de Andrade e Mário de Andrade, enfatizando seu ponto de vista afirmará:

Em 1924, publicando, no Recife a 'carta literária' A Arte Moderna, escrevi: - 'Graça Aranha, como todos sabem, trouxe para o Brasil o credo da Arte Nova'...

Com esta frase inocente, abria-se um debate que perdura ainda hoje, sobre a precedência de Graça Aranha na renovação literária brasileira. Quase imediatamente, surgia a reação de Luís da Câmara Cascudo, numa carta de 8-3-25, falando-me justamente, de A Arte Moderna: 'Eu de mim discordo com a prioridade do Graça no movimento. Já V. estava fazendo reação. Os paulistas tinham feito a Semana de Arte Moderna. Havia a Paulicéia do Mário...O Graça tornou o movimento coletivo. Não acha? ${ }^{108}$

(...)

A controvérsia não parece haver-se liquidado com as críticas dos modernistas de 22. Quarenta e seis anos depois da Semana Paulista, ao festejar-se o $1^{\circ}$ centenário do autor de Canaã, continua no tablado das discussões a tese da precedência graçanhista.

$\mathrm{Na}$ biografia do escritor maranhense, dois marcos lhe irão definindo, de qualquer forma, a luminosa trajetória de 'renovador': Canã̃ e $O$ Espírito Moderno (INOJOSA, 1975a, p. 5-6).

Em 1980, José Américo, afastado da vida pública e morador da Praia de Tambaú em João Pessoa, Paraíba, faleceu deixando vaga a cadeira número trinta e oito na Academia Brasileira de Letras. É essa vaga que Joaquim Inojosa disputará e perderá para o ex-presidente José Sarney. O livro José Américo de Almeida: algumas cartas,

${ }^{108}$ Cf. (CC, 8-III-1925, apud, ARAÚJO, 2012, p. 98). 
portanto, deve ser visto como estratégico instrumento para construir a ideia de uma amizade de vida inteira com esse imortal (BARROS, 2012, p. 223-224):

As cartas que vão se ler (...) revelam admiráveis facetas da invulgar personalidade de José Américo de Almeida: a do escritor e do amigo. Da primeira aí está clara confissão de se haver integrado com o movimento modernista de 1922, iniciado em São Paulo com a Semana de Arte Moderna e no mesmo ano divulgado em Pernambuco. (...) Da segunda, a confissão intima de que estava comprometido com alguns nomes para uma vaga na Academia Brasileira de Letras, mas se o amigo, na sua 'legítima aspiração' viesse a candidatar-se, saberia explicar como se achava obrigado a apoiá-lo (INOJOSA, 1980, p. 17$18)$.

O trecho acima mostra como Joaquim Inojosa procurou construir sua carreira de escritor. Apropriou-se da memória do movimento modernista, usando e abusando da autoridade e legitimação de seu papel de divulgador no Nordeste dos anos de 1920. Construiu e reconstruiu relações de amizades que lhe permitiram adentrar e permanecer em alguns espaços de reconhecimento intelectual e político.

Embora seus discursos, seus adversários e seus interesses aparentemente o ligassem a Pernambuco, ao Nordeste, eram o Rio de Janeiro e a Academia Brasileira de Letras os espaços de sua desejada consagração. É sintomático que publique as cartas de José Américo de Almeida como meio de construir sua genealogia e para mostrar-se autorizado pelo "dono da cadeira" a ocupa-la (BARROS, 2012, p. 224).

No ano 1966, quando decide publicar o Movimento Modernista em Pernambuco, Joaquim Inojosa convidará seu velho amigo José Américo de Almeida para participar deste projeto, concedendo uma entrevista sobre o processo criativo de A Bagaceira e de suas tendências modernistas. Neste sentido, o crítico pernambucano, instigou o debate entre modernistas e regionalistas, colocando o respectivo romance como elemento de disputa ideológica, conforme veremos a seguir.

5.2. A contribuição de José Américo de Almeida para O Movimento Modernista em Pernambuco: correspondência e crítica genética (1966-1968)

Na opinião de Albuquerque Jr. (2011), A Bagaceira, de José Américo de Almeida, é seu livro de maior repercussão. Uma obra nitidamente de transição entre 
duas estéticas: a naturalista e a modernista. Este romance aborda a transição entre duas sociabilidades: a patriarcal e a burguesa. Um livro, por isso, cheio de ambiguidades, no qual a influência da estética modernista e as pregações regionalistas de Gilberto Freyre surgem entrelaçadas com nítida influência de Euclides da Cunha, seja no que toca a observações saídas de seu cientificismo positivista, seja no próprio estilo metafórico, apoiado em analogias extraídas da natureza e no uso insistente de proparoxítonos e de longos paroxítonos que marcavam o estilo daquele autor (ALBUQUERQUE, 2011, p. 156).

O estudo de D'Andrea (2010) corrobora esta argumentação, demonstrando que ao surgir em 1928, A Bagaceira fora inscrita no painel da literatura brasileira como iniciadora do romance modernista. Ao mesmo tempo, pelo aspecto de particular reparo à região nordestina, é conferido também ao romance o título de "iniciador do romance regionalista” que viria a seguir, inaugurando a década de 1930. Dessa maneira, é nessa postura um tanto incômoda - um pé no Modernismo e outro no Regionalismo - que ele vem sendo discutido na maioria das vezes pela historiografia literária (D'ANDREA, 2010, p. 187).

Joaquim Inojosa, em carta de três de janeiro de 1966, parecia já se colocar como uma das primeiras vozes a se posicionar no tom desse debate:

Em 1928, José Américo de Almeida - que era, já, o autor da novela 'Revelações de uma Cabra' e do livro 'Problemas da Paraíba'109 publica o extraordinário 'A Bagaceira', marco inicial da literaturasocial no romance brasileiro.

A crítica literária de hoje em dia divide-se no apreciar que influências teria sofrido o autor para escrever o livro excepcional.

a) - a de que José Américo de Almeida sofrera influência do movimento modernista de São Paulo, largamente difundido entre Paraíba e Pernambuco, na sua fase de nacionalismo ou brasilidade;

b) - a de que 'A Bagaceira' foi o primeiro fruto do Regionalismo tradicionalista do Centro Regionalista do Nordeste;

c) - a de que não teria sofrido influência de qualquer dos dois... "movimentos" [...] (JI, 3-I-1966).

\footnotetext{
109 Joaquim Inojosa equivocou-se sobre os títulos das obras de José Américo de Almeida a que faz menção nesta passagem da carta citada. Trata-se, na verdade, de Reflexões de um Cabra (1971) e de $A$ Paraíba e seus Problemas (1984).
} 
Inojosa, nessa correspondência, confessava que sinceramente sentir-se-ia feliz se pudesse reencontrar o amigo e esclarecer o assunto, que era de interesse para a história da literatura brasileira pois, para ele, José Américo de Almeida era um dos co-autores mais eminentes da nova literatura social brasileira. Tantos anos depois, não mais o estudante de vinte anos de idade, mas o sexagenário continuava a se referir àquele autor como "mestre insigne" e "o mais vigoroso, sincero, e forte intelectual da Paraíba" - e a ele novamente se dirigindo, na qualidade de "discípulo", modernista, "É o que espera(va) ao subscrever-se, o "discípulo" da "Carta de Um Estudante"," que é o mesmo desta carta" (JI, 3-I-1966).

No intuito de dar veracidade a suas teses e "esclarecer" o controvertido assunto, Inojosa, na companhia de Ivan Bichara ${ }^{111}$, saiu à procura de José Américo, quando de uma visita feita pelo escritor paraibano ao Rio de Janeiro em 1966, e expôs as dúvidas que os críticos literários estavam criando no espírito do leitor da época, no que se referia a possíveis influências que teria sofrido o autor paraibano ao escrever A Bagaceira (cf. INOJOSA, 1968a, v.1, p. 200).

Em carta de sete de janeiro de 1966, Inojosa comunica o envio do apanhado da conversa anunciada na carta anterior, mencionando que, se José Américo concordasse, publicaria seu depoimento no capítulo que estava a desenvolver sobre A Bagaceira no livro O Movimento Modernista em Pernambuco (1968). Aguardava uma resposta mais incisiva, desculpando-se por tomar o tempo do amigo, "mas desejaria colocar os pontos nos ii nisto de José Américo ser fruto de Gilberto Freyre, ou melhor, 'Bagaceira' ter surgido sob influência de congressos regionalistas..."(JI, 7-I-1966).

Só em vinte e quatro de fevereiro de 1966, o escritor José Américo de Almeida, já em João Pessoa, Paraíba, envia-lhe carta, mencionando que modificou apenas dois ligeiros traços; pedia desculpas pela demora em responder, devido ao fato de ter chegado do Rio incapacitado até para escrever uma carta, mas desejava "votos pelo êxito do seu próximo livro que terá como sempre, a marca de sua consciência de escritor":

\footnotetext{
110 Ao receber de José Américo um exemplar da conferência Poetas da Abolição, Joaquim Inojosa, dedicou-lhe em vinte de setembro de 1921, através das colunas do jornal A União, dirigido à época por Carlos Dias Fernandes, a respectiva carta, falando de sua admiração, mas também estabelecendo crítica à conferência do escritor paraibano (Cf. INOJOSA, 1980).

${ }^{111}$ Ivan Bichara Sobreira (1918-1998), político paraibano, crítico literário e romancista, sua obra mais expressiva foi o romance Carcará (1984), que fora dedicado a José Américo de Almeida.
} 
Recebi sua carta e fiquei pensando. O apanhado do nosso encontro está muito bem lançado, mas me coloca numa posição que, definida por mim, me deixa de certo modo contrafeito. São coisas que poderão ser expressas por outras pessoas, sem reivindicação de minha parte.

Gostaria assim que você eliminasse da segunda página o período que começa por Por isso considero...e o que começa por Jamais me deixei... (JAA, 24-II-1966, apud, INOJOSA, 1980, p. 27).

A entrevista concedida por José Américo a Joaquim Inojosa, depois das alterações sugeridas, e conforme o que ficou acordado entre os amigos, foi publicada no livro O Movimento Modernista em Pernambuco (1968). Nela, Almeida confessava, pela primeira vez, que levara cerca de três anos para concluir o romance, fruto do Modernismo em voga (INOJOSA, 1980, p. 27-28):

À proporção que o Modernismo se expandia, inclusive no que representava de polêmico em Pernambuco, foi-se concretizando dentro de mim a idéia de igualmente formarmos uma reação nordestina contra os cânones antigos, a que se chamava "passadismo", sem que perdêssemos o sentido universal da cultura brasileira. Reagir como nordestino, queria dizer, aproveitar tipos, linguagem, costumes regionais do Nordeste, secas e cangaços, dentro da integração nacionalista pregada pelos modernistas. Literatura universalista, pois que a literatura, mesmo que fixe aspectos regionais, não perde, por isso, o seu aspecto de universalidade (INOJOSA, 1968a, v. 1 p. 202203).

Ao tratar d"“A Inspiração Modernista de 'Bagaceira”" 112, Joaquim Inojosa afirmou, com base no já apresentado, que seria, portanto, uma tolice vincular ao Regionalismo tradicionalista recifense os escritores nordestinos daquele período posterior. Um ano antes do regresso de Gilberto Freyre, o escritor paraibano publicava Reflexões de um Cabra (1971) que, no olhar de Inojosa, tratava-se de um pré-Bagaceira, e pouco depois um alentado livro estudando problemas sertanejos - A Paraíba e seus Problemas (1984) —, afirmando que quem vivera "entre Recife e Paraíba (referindo-se aqui à atual cidade de João Pessoa - PB), de 1922 a 1930, não pode sem imperdoável

\footnotetext{
112 Ainda no ano de 1968, Inojosa publicou em $O$ Jornal, um artigo intitulado "A Revolução da Inteligência e da Cultura no Nordeste", onde realiza a aclamação das suas ideias sobre A Bagaceira, que por nós já foram aqui apresentadas, e como querendo dar início a propaganda do Movimento Modernista em Pernambuco (Cf. INOJOSA, 1975a, p. 1-3).
} 
parti-pris, subordinar a obra prima de José Américo de Almeida aos artigos seriados de G.F. ${ }^{113}$ ou a um Congresso Regionalista que primou pela ausência de escritores e literatura, inclusive o ilustre paraibano" (INOJOSA, 1968a, v.1, p. 197-198).

Embora José Américo não tenha participado do Congresso Regionalista, todavia, fora precipitação de Inojosa afirmar tão categoricamente que o escritor de A Bagaceira não tenha tido nenhum contato com Freyre. Antes mesmo da publicação da Arte Moderna em cinco de julho de 1924 na revista Era Nova, da Paraíba, vimos que houvera sim uma aproximação entre aqueles intelectuais. Tendo por base outros documentos, em especial as cartas que Gilberto Freyre enviou a José Lins do Rêgo, vemos o autor de Casa Grande \& Senzala agradecer o interesse de alguns intelectuais da Paraíba, no sentido de publicarem a conferência que havia proferido em João Pessoa, em cinco de abril de 1924 — Apologia pro generatione sua ${ }^{114}$ —, no Teatro Santa Roza. A conferência foi publicada no mesmo ano pela Imprensa Oficial da Paraíba, provavelmente em junho. Traz, em sua capa, os nomes dos intelectuais que formavam a comissão "sob cujos auspícios esteve Gilberto Freyre na Parahyba". Entre os mais conhecidos, estavam Carlos Dias Fernandes, José Américo de Almeida, Adhemar Vidal, Antenor Navarro e José Lins do Rêgo. Conforme demonstra ainda Figueiredo Jr (2000), em carta de dezesseis de junho de 1924, do Recife, o líder regionalista pernambucano fala com muito entusiasmo do romance de estreia de José Américo a José Lins do Rêgo: "Estou ansioso pelo Bagaceira. Que título feliz! Um título assim dá sabôr a um livro" (FIGUEIREDO JR, 2000, p. 48).

Aqui nos voltamos à função paradigmática de A Bagaceira. Trazendo para a ficção o referencial de uma realidade que até então tivera seus melindres de tratamento, José Américo de Almeida, mesmo com uma organização formal quase nada inovadora e com um forte componente de Naturalismo determinista, abre caminho para as duas soluções ficcionais que se lhe sucederiam: o tratamento formalmente moderno, mas ambíguo, entre as mazelas escravistas no eito dos engenhos - José Lins do Rêgo - e o tratamento de "uma faca só lâmina" que a ficção contra-ideológica, manifesta na linguagem de Graciliano Ramos, trazem para os romances de 1930 (D'ANDREA, 2010, p. 211).

\footnotetext{
${ }^{113}$ Série de cem artigos escritos por Gilberto Freyre, iniciados quando o mesmo ainda residia nos E.U.A, publicados no Diário de Pernambuco, entre 22 de abril de 1923 e 15 de abril de 1925, e republicados no livro Tempo de Aprendiz (FREYRE, 1979b).

${ }^{114}$ A respectiva conferência pode ser consultada na obra Região e Tradição, (Cf. FREYRE, 1968, p. 7998).
} 
Freyre, ao tratar do regionalismo tradicionalista, dirá que no campo da ficção o extraordinário viço literário da renovação cultural do Nordeste encontrava nas páginas de A Bagaceira sua melhor expressão. De acordo com o autor, José Américo teria sido o primeiro escritor moderno da região nordestina a ser lido pelo grande público brasileiro. Acreditando que desde A Bagaceira, desde os primeiros poemas de Jorge de Lima e as primeiras páginas de prosa ao mesmo tempo realista e poética de José Lins do Rêgo, se notava naqueles "renovadores" uma tendência para conciliarem o regional com o humano, a tradição com a experimentação, o gosto pela renovação do método literário, científico ou artístico com a simpatia humana pelo assunto regional e pelo público brasileiro. Tendência que só mais tarde - com os pós-modernistas - se acentuaria nas "zonas de influência" do chamado "modernismo" brasileiro (FREYRE, 1968, p. 53; 55).

Significativo, no entanto, é o fato de que Gilberto Freyre, em artigo intitulado “A reinterpretação", escrito em 1978, coloque a obra de José Américo fora da órbita de influências do Movimento Regionalista-Tradicionalista, o que de certo modo termina por desestabilizar as prerrogativas de Inojosa; e contradizer o que desde muito cedo afirmou com veemência, ou seja, a filiação de José Américo a seu regionalismo tradicionalista:

Com A Bagaceira principiou no Brasil a voga de um romance ao mesmo tempo que moderno - sem Modernismo à la Semana de Arte Moderna - social e regional (...) Daí, no que tenho escrito acerca do Movimento Regionalista, saído do Recife desde o começo da década de 20, nunca ter filiado José Américo de Almeida a esse movimento ou ter sugerido, na sua obra, influência assimilada pelo autor daquela interpenetração que, na década de 20 , processou-se inovadoramente no Recife acrescentando a perspectiva de renovação artística ou literária iniciada em São Paulo como "modernista" a socialmente ou filosoficamente social do Nordeste, como região, e do Brasil, como nação com valores tradicionais susceptíveis de modernização (FREYRE, 1978, p. 93. Grifo nosso).

O que se depreende desta última argumentação é, já passados mais de cinquenta anos da Semana de Arte Moderna, e com o estabelecimento do cânon modernista, Freyre irá propor que seu regionalismo tradicionalista era, a seu modo, modernista, mas de todo independente do Modernismo Rio-São Paulo, do qual na opinião do autor tanto se falava, às vezes esquecendo-se desse outro movimento da mesma época saído do 
Recife e seu chamado "Manifesto Regionalista", apresentando - como pronunciamento que definisse suas orientações - ao Congresso Regionalista organizado em Recife em 1926. Já então, conforme argumentou, o movimento viria se desenvolvendo desde 23 ou 24, ou até mesmo em meados de 1918 (FREYRE, 1976, p. 15).

Longe de ficar procurando que movimento foi precursor da Bagaceira no campo cultural, ou qual deles influenciou José Américo de Almeida, o que fica de relevante nesse diálogo é o processo criativo da obra O Movimento Modernista em Pernambuco de Joaquim Inojosa e da rede de sociabilidade que se estabelece com José Américo de Almeida, demonstrando o quão importante foram as correspondências para as proposições aqui estabelecidas.

5.3. "E agora, eis me chega o Cascudo puro, purinho... forte de espírito e amizade, redivivo em tudo": memórias modernistas na correspondência de Cascudo e Inojosa (1968-1984)

Como já fora mencionado anteriormente, através de relevante passagem do livro de memórias Na Ronda do Tempo (1998b), de Câmara Cascudo, dos impactos causados pela campanha modernista em Pernambuco até meados de 1927 ao reencontro de Cascudo e Inojosa em 1969, haviam se passado 45 anos. Todavia, ao que parece, o contato foi retomado em 1968; quando da publicação e do lançamento do Movimento Modernista em Pernambuco (1968-1969). De acordo com Araújo (2012), o aparecimento desse livro desequilibra a rotina do velho folclorista, que talvez não se preocupasse mais com aquele passado determinante da sua formação intelectual. $\mathrm{O}$ tom da sua escrita, nas cartas endereçadas a Inojosa, é saudosista; ao puxar da memória, realçando com o efeito estético das reticências, os tempos imemoriais, elogia a "previdente meticulosidade" do amigo que recolheu "as folhas que o vento inspirador arrancava de nossos nervos juvenis...", confessando-se deliciado ao "reler e voltar ao ritmo daqueles meses inesquecíveis e tumultuosos, jamais repetidos sob Céu pernambucano" (ARAÚJO, 2012, p. 73):

O MOVIMENTO MODERNISTA EM PERNAMBUCO agiu como dose maciça de proteína. Estou deixando o Hospital depois de algum tempo de shek-up, repouso e vigilancias na base da cavilação e do 
dengo ${ }^{115}$. (...) Seu livro carregou as baterias na viagem inesperada aos 26 anos, aspirando clima de quarta dimensão. (...) Nada se perdeu e V. reapresentou as lembranças materiais do movimento na graça airosa de um ramalhete completo e fiel. Quanta gente que dormia no fundo da memória reviveu e voltou à tona, contemporânea e lógica! ${ }^{116}$...Delícia para reler e voltar ao ritmo daqueles mêses inesquecíveis e tumultuosos, jamais repetidos sob o Céu pernambucano. V. foi o curisco acendedor da coivara. As cinzas, graças à V., viraram cimento, monumento, arranha-ceu. (...) (CC, 29-V-1968; apud, ARAÚJO, 2012, p. 109).

Nessa dimensão, surge a ótica de encarar o movimento modernista como uma campanha de "meses" agitados que passaram a ser revistos a partir de um ato heroico: Inojosa fora nomeado de "curisco acendedor da coivara". Tal qual o efeito da Fênix, o Modernismo é revivido e monumentalizado: “As cinzas, graças a $V$., viraram cimento, monumento, arranha-ceu". O assunto principal dessa primeira carta dos anos sessenta, com um único e extenso parágrafo, datilografado, demonstra a recepção de Cascudo frente a O Movimento Modernista em Pernambuco, cujos dois primeiros volumes haviam sido publicados naquele momento. No corpus documental em questão, foram identificados quatro documentos datados do ano de 1968, sendo duas cartas de autoria de cada um dos missivistas, as quais formam uma pequena série em diálogo. O início da série se dá em vinte e nove de maio daquele ano, com uma carta enviada por Câmara Cascudo, terminando em quatorze de outubro com uma carta de Joaquim Inojosa. A ênfase no assunto principal das quatro epístolas é a referida obra, além da polêmica criada por Inojosa em torno da publicação, em 1952, do Manifesto Regionalista de 1926 escrito por Gilberto Freyre; este último aspecto será tratado na secção posterior; neste momento do texto, trataremos das primeiras impressões e da relevância destas para estimular Cascudo a escrever sobre suas memórias dessa época no livro Gente Viva (2010b) (ARAÚJO, 2012, p. 73-74).

\footnotetext{
${ }^{115}$ Esta seria a segunda temporada de internação, que ocorrera em abril de 1968 (a primeira em agosto de 1967). Ambas ocorreram no Hospital das Clínicas em Natal. De acordo com Cascudo essa iniciativa teria sido intermediada por Onofre Lopes (reitor da UFRN à época); tendo-o sujeitado a um check-up investigador. No Pequeno Manual do Doente Aprendiz, vemos a retomada do mesmo aspecto no prefácio da referida obra: (...) "O ambiente é inesquecível. (...) médicos, enfermeiras, serventuárias, da cúpula à base dos serviços hospitalares, trataram-me, não apenas no critério do afeto e do interêsse cativantes, mas sob as fórmulas familiares do dengo e da cavilação sentimentais". (CASCUDO, 1969, p. 10). Ao que se pode perceber na correspondência de Cascudo enviada a Inojosa em 16-IV-1969 e 26-IV-1969, esta obra fora doada ao autor do Movimento Modernista em Pernambuco (Apud, ARAÚJO, 2012, p. 114-115).

116 Grifos nossos.
} 
Na carta de Inojosa que se segue em vinte e um de julho de 1968, o escritor descreve a sensação de arrebatamento em receber uma missiva do velho amigo: (...) "a sua carta me arrebatou as janelas da casa de solitário, numa tempestade de emoção, e arejou tudo, alma, coração, mente, biblioteca, a vida, enfim...Que alegria vê-lo dessa forma!...” (JI, 21-VII-1968; Apud, ARAÚJO, 2012, p. 110). Afirmou que apesar da distância, sempre acompanhara palmo a palmo as suas vitórias nas letras, seu glorioso renome nacional e internacional, livros, colaboração de imprensa, contatos de amigos; e naquele instante lhe "chega(va) o Cascudo puro, purinho, aquêle das suculentas sopas na pensão da Rua do Imperador, festivo, forte de espírito e amizade, redivivo em tudo". Depõe ao velho amigo que o que fizera fora apenas esclarecer episódios e relembrar nomes. Tratou de retificar aqueles pontos que em sua opinião tentavam ocultar o poder jovem daquele instante, endossando que somente os críticos, os historiadores, poderão dizer se havia acertado em sua iniciativa (Idem, ibidem, p. 110).

Frente aos elementos apresentados nestas missivas, verifica-se que a participação de Joaquim Inojosa no movimento modernista se deu praticamente no âmbito da divulgação, em um contexto de produção jornalística:

\footnotetext{
Você, amigo, bem o fixou - e isto me honra -, quando escreveu que 'reviveu e voltou à tona, contemporânea e lógica', muita 'gente que dormia no fundo da memória'. Ora, sendo o famoso Cascudo testemunha da época, coartífice do que Moraes Coutinho chamou de 'pé-de-vento literário', a expressão constitui uma sentença, e irrecorrível pelo gabarito de quem a pronuncia (JI, 21-VII-1968, apud, ARAÚJO, 2012, p. 110).
}

Durante o período em análise, Cascudo se distanciava do perfil inserido na linha do Modernismo regionalista e folclórico da campanha pernambucana; o missivista que responde ao velho amigo teve outras vivências no mundo literário brasileiro, vendo, portanto a época de maneira diferente. É possível verificar que tais fatos se refletem no modo de organização do livro Gente Viva (2010b), que seriam para esta pesquisa, em princípio, memórias modernistas inspiradas no acervo documental publicado pelo amigo Inojosa, embora, dos 43 nomes rememorados nos capítulos do livro, menos da metade atuou, de fato, no movimento modernista. O eixo básico da evocação presente nesta obra são as vivências recordadas das passagens do jovem Cascudo pelas cidades de Salvador, Rio de Janeiro e Recife, em período de formação universitária. Escrevendo 
do ponto de vista de um já septuagenário, ele revela em carta de 3 de setembro (ARAÚJO, 2012, p. 84):

Estou para matar o tempo que nos sepultará, batendo lentamente um livro sobre meus amigos viajados. GENTE VIVA! Porque a morte existe, os Mortos, não.

Foi a vez do Guilherme de Almeida...Não posso separá-lo de V. em 1925. Fora a primeira impressão. (CC, 3-IX-1969, apud, ARAÚJO, 2012, p. 117).

Essa afirmação de Cascudo estava anexada ao capítulo que vinha junto dessa missiva, demonstrando que falar de Guilherme Almeida, um dos grandes nomes do Movimento Modernista, não era possível sem o associar ao nome de Joaquim Inojosa:

\footnotetext{
Joaquim Inojosa tentara motorizar as deligencias e cabriolés circulantes nas ruas literárias do Recife em 1925. Era O Movimento Modernista em Pernambuco, espoucante e agitador, que ele expos e documentou em dois volumes maciços, (Rio de Janeiro, 1968). Havia prosa e verso, sátira, elegia e louvor nos ritmos bonitos e maquinais como águas do Capibaribe ornamental. Vivia-tranquila, comum, portuguesamente, como dizia Ascenso Ferreira. Havia, farto fácil, de um tudo sob os modelos da Tradição. Joaquim Inojosa espantou a marcha regular e segura, como fazia o Sací Pererê na cavalhada sulista. Para remate e reforço ao torvelhinho, trouxe, em novembro, Guilherme Almeida, invencível ventania melódica do Anhangabaú. (CASCUDO, 2010b, p. 81).
}

No período correspondente à segunda fase da correspondência com Joaquim Inojosa, Cascudo revela sua posição, na velhice, como memorialista que revisita o repertório acumulado ao longo do século $\mathrm{XX}$, incluindo-se aí o legado modernista que não é reivindicado em absoluto. Ainda em Gente Viva, por exemplo, Câmara Cascudo reitera o princípio da autenticidade como padrão de valorização artística do elemento regional, sobretudo nas observações sobre Catimbó, de Ascenso Ferreira, publicado no ano de 1927. Nesse capítulo de Gente Viva, a ideia da agitação cultural daquele momento é narrado em certo tom de leveza, como se não existissem tensões em torno de necessárias tomadas de posição que eram demandadas pelas pressões dos programas literários e culturais e se constituem como uma escrita autobiográfica, sem a 
preocupação do arquivista identificado na perspectiva adotada por Joaquim Inojosa em suas memórias modernistas (ARAÚJO, 2011, p. 89):

(...) A movimentação, alacridade, ruído de vozes discutindo, berros de protesto, estridência de risos, exibição de cantos e mesmo toques de violão, centralizavam as preferências, provocando os encontros para confidências poéticas, combinar artigos de jornal, duelar entre as predileções artísticas. (...) (CASCUDO, 2010b, p. 101-102).

Nesse sentido, podemos constatar que a análise dessa epistolografia nos permite uma espécie de contato muito próximo com os sujeitos da história que pesquisamos. Nela, "nossos" atores aparecem de forma fantasticamente "real" e "sem disfarces". Nós, historiadores, podemos passar a conhecê-los na "intimidade" de seus sentimentos e nos surpreendemos a dialogar com eles e até a imaginar pensamentos. Ambos têm um nome próprio como marca identitária; entretanto, ambos são também muitos outros construídos por um autor e que se transformam ao longo do tempo, assumindo formas e cores diferenciadas (GOMES, 1998, p. 126).

Nessa correspondência, não só O Movimento Modernista em Pernambuco e Gente Viva serão enunciados e enaltecidos. Perpassam por essa correspondência o comentário de outras obras dos respectivos autores, sendo exemplos das obras de Cascudo: Na Ronda do Tempo, Ontem, História dos Nossos Gestos e Prelúdio da cachaça; e, de Inojosa: Os Andrades e outros aspectos do modernismo (1975a), Notas Biobliográficas de Joaquim Inojosa (1975b), A Arte Modernal Brasil Brasileiro (1977) e 60 anos de jornalismo (1917-1977) (1978a). Além destes registros em perspectiva de elogio mútuo, ocorreu também o apontamento e debate de alguns títulos de Joaquim Inojosa que tratam sobre sua polêmica e crítica a Gilberto Freyre: No Pomar Vizinho (1968), Carro Alegórico (1973) e Pá de Cal (1978b). Na secção a seguir, nós nos voltaremos à segunda tipologia.

Em carta de quatorze de outubro de 1968, vemos Inojosa na condição de "devoto da cachaça", mas não como "cachaceiro", realizar uma elegia ao amigo de longa data e a uma de suas recentes obras, lançadas à época, pois nessas páginas de mestre, com o “Cascudíssimo" ninguém podia, "aprende cachaceiro e aprende quem não é cachaceiro. Basta[va] ler o "Prelúdio da Cachaça": 
O da 'Cachaça', do alambique do Cascudo, serve de aperitivo. Porque cachaça, hoje da boa, nem cheiro deixa mais. Toma-se como aperitivo. É artigo de exportação para americano bêsta.

(...)

E hoje, Cascudíssimo, sou 'devoto da cachaça', mas não sou 'cachaceiro', como reconhece V. do brasileiro em geral. Pois nuns almoços semanais entre amigos, começamos sempre por uma 'batida' - em que, aliás, me tornei perito. Garanto-lhe, porém, que a nossa orquestra não sai do 'prelúdio'... embora o 'suco' desça, com ou sem 'pancada do ganzá'...

O certo é que com Você ninguém pode: aprende cacheceiro e aprende quem não é cachaceiro. Basta ler o 'Prelúdio da Cachaça'. Nas suas páginas de mestre até êste se reconcilia com a bebida e justifica-a, através de todos os tempos, como um elemento de camaradagem entre os homens de folclore, 'valorizada' 'literariamente', numa 'extensão de quatro séculos' (JI, 14-X-1968, apud, ARAÚJO, 2012, p.113).

Em cartas de treze de outubro de 1969 e de vinte e um de junho de 1971, Cascudo trata do projeto editorial de dois de seus livros de memórias; o primeiro, aqui já mencionado, Na Ronda do Tempo, pede para o velho amigo consultar a página 20, para ver o registro que Cascudo fazia do reencontro dos velhos modernistas; o segundo "seria suas notas de professor provinciano", Ontem, pedia que o amigo os anunciasse na imprensa carioca:

INOJOSA querido: - Ecce iterum... Lá vai bestêira... Uma página do meu diário, UM ANO DE VIDA, que terminará, o diário e não a vida, como espero, com esse 1969 (CC, 13-X-1969, Id. Ibidem, p. 119).

HINOJOSA querido. Veja esse 'Na Ronda do Tempo', meu diário de 1969, que ficaria inédito, divulgado parcimoniosamente, não reeditável, numa doce violência do reitor Onofre Lopes, despedindose dos 12 anos de Reitoria. Veja a pag-20, sua visita. Estou batendo um volumeco unicamente sobre a minha vida de professor, didática, pedagogia, anedotas, alunos, figuras, críticas, sugestões, conclusões, etc. Chamar-se-á $\underline{O N T E M}$, notas de um professor provinciano. Incluo uma 'curiosidade' pouco circulável, superstições de estudantes, solicitando abrigo no velho JORNAL. Antecipado agradecimento e receba afetuoso e distante abraço (...) (CC, 21-VI-1971, Id. Ibidem, p. 130). 
No dia trinta de julho de 1971, Inojosa escreve ao amigo, parabenizando e agradecendo a alusão a sua lembrança na obra $\mathrm{Na}$ Ronda do Tempo, que com ou sem referência sentimental, seria um livro raro, de beleza intima, onde espocavam, vez ou outra, páginas antológicas, como as que faziam referência aos brinquedos de criança. Informou que só poderia escrever uma crônica sobre o mesmo, a partir do dia oito do mês subsequente, mas acusava o recebimento. O autor de A Arte Moderna parecia concordar com a receita de Cascudo, "ocupar-se para não preocupar-se", pois, "Velho vive de trabalho; criou vazio da vida, está frito. Sobretudo, como no seu caso, velho apenas pelo calendário". Isto não queria dizer que não se necessitassem de certos cuidados, em especial com o coração, pois ele não teria "achatado", porque tinha como Cascudo "a mesma fibra (...) de caroá dos primeiros tempos, ainda meio selvagem, sertanejo puro...":

Pensava enviar-lhe uma crônica sobre a 'Ronda'. Mas isto sômente será possível pelo 'O Jornal' de domingo, 8. Assim, aqui vai a notícia que o recebi (...).

Cascudo querido: Que livro escreveu Você! Um poema de dinamismo. E refere cuidados domésticos com a saúde! Qual nada! Velho vive de trabalho; criou o vazio da vida, está frito. Sobretudo, como no seu caso, velho apenas no calendário. Isto não quer dizer que certa emoção não possa ameaçar-lhe o coração. Por exemplo, no meu caso particular, a leitura do que V. escreveu na pág. 20 sôbre o nosso reencontro, só mesmo não me achatou porque o velho de cá possui a mesma fibra do de lá - aquela de caroá dos primeiros tempos, ainda meio selvagem, sertanejo puro...

Com ou sem esta referência sentimental, V. escreveu um livro raro, de beleza íntima, no qual espoucam, vez outra, páginas antológicas, como aquela sôbre os brinquedos de crianças. Livro que é uma enciclopédia de sabedoria e dinamismo. Saber que não acaba mais; dinamismo que não tem fim. Que cabra-da-peste genial! Isto é, por toda parte, um pé de jerimum. Acontece que se êste alimento vitaminado produzisse 'cascudos', o Nordeste estaria cheio dêles, e pelo que me consta, um só produziu o Brasil até hoje (JI, 30-VII-1971, Id. Ibidem, p. 131). 
Durante o final do ano de 1975 e início de 1976, vemos uma série de cartas entre Cascudo e Inojosa, que nos chama bastante atenção. Nelas serão abordados os livros de Joaquim Inojosa Os Andrades e outros aspectos do modernismo (1975a) e Notícia Bibliográfica (1975b). Iniciando a série, vemos que Cascudo considerou o primeiro como um tomo complementar do Movimento Modernista em Pernambuco. Já sobre o segundo, Inojosa o tomou como quase livro de memórias, e ao comentar sobre a publicação deste último, demonstrou a preocupação com a solidão, com o que faria de seu acervo caso morresse de repente.

O livro Os Andrades e outros aspectos do Modernismo reuniu as crônicas publicadas no $O$ Jornal, tem em sua nota de abertura a informação posta pelo autor de que a sua única pretensão era esclarecer pontos ainda obscuros do movimento modernista brasileiro, ressaltando o aparecimento de obras a ele direta ou indiretamente vinculadas: "simples pormenores que as pesquisas revelam adormecidos, todavia essenciais à compreensão dos acontecimentos que definiram, a partir de 1922, a maior revolução cultural brasileira de todos os tempos". Entre as crônicas publicadas, a de doze de março de 1969 parece justificar o título da coletânea; “Os Andrades do Modernismo". Na crônica, Inojosa tratou de Carlos Drummond, Mário, Oswald e Guilherme de (Andrade) Almeida (BARROS, 2012, p. 163):

\footnotetext{
Não falarei de todos. Na verdade ostentam Andrade vários dos principais arquitetos do modernismo brasileiro. Deixarei de lado os menores, para citar apenas os que destes se distanciaram pela imortalidade de suas obras literárias.

(...)

Registra a história literária os nomes destes quatro Anjos (Cavaleiros) do Apocalipse: Mário de Andrade, Oswald de Andrade, Guilherme de (Andrade e) Almeida e Carlos Drummond de Andrade. Falo do apocalipse porque lhe encontro, na leitura, versículos que bastante se lhes ajustam às atitudes nas batalhas modernistas e ao perfil moral de cada um deles. (INOJOSA, 1975a, p. 19).
}

Para entendermos o sentido estratégico dessa publicação, devemos saber que o autor se chamava Joaquim Inojosa de Albuquerque Andrade Lima. Certamente, a escrita mobilizada em torno da memória do movimento modernista e de seus célebres participantes pode ser interpretada como maneira de construção de uma genealogia, de enquadramento de um lugar relevante para si na história cultural do país. "Deixarei de 
lado os menores, para citar apenas os que destes se distanciaram pela imortalidade de suas obras literárias". Por meio dessa rápida passagem, percebemos como estrategicamente Inojosa entrelaça sua trajetória intelectual a Carlos Drummond, Mário, Oswald e Guilherme de Almeida, criadores e divulgadores do modernismo brasileiro (BARROS, 2012, p. 164).

Cascudo, em vinte e sete de novembro de 1975, agradece o envio de "Os Andrades", comenta sobre a visita que fizeram juntos à Academia Brasileira de Letras, suas lembranças de Guilherme de Almeida, a quem devia apresentação afetuosa no Recife saudoso do seu tempo. Aproveita o ensejo para falar do processo de editoração do História dos Nossos Gestos:

OS ANDRADES serão lidos como se bebia kümmel outrora: vagaroso e às gotas. Um tomo complementar do movimento 'Modernista', comunicado com limpidez, autoridade, independencia. Estes são os três valores básicos de sua notavel obra em nossa História cultural. De leitura e citação indispensáveis na espécie. Antecipo não apenas o abraço pelo envio como à homenagem consagradora e graciosa às primeiras páginas do livro. Incluso uma visita à $\mathrm{ABL}$ em fevereiro de 1969 ouviu minha falação afirmando-me sempre noivo, sem responsabilidades conjugáis pela distancia de residencia, impossibilitando convivência fecunda. (...)

Assinei contrato com a Melhoramentos de S. Paulo para edição do NOSSOS GESTOS, uma antiga pesquisa da mímica brasileira, no Tempo e no Espaço. Velho desejo de publicidade, tratando-se de esforço antigo em assunto novo na bibliografia brasileira. Grato pela visita dos ANDRADES, tão diversos entre si, e do Guilherme de Almeida, de quem lhe devo apresentação afetuosa no Recife do nosso tempo saudoso. (...) (CC, 27-XI-1975, Id. Ibidem, p. 145).

Ao comentar sobre esta última carta, em cinco de dezembro de 1975, observamos que Inojosa, por intermédio de Os Andrades e outros aspectos do modernismo, realizou afago similar ao feito pelo velho amigo potiguar ao enviar $\mathrm{Na}$ Ronda do Tempo, lembrando que não “esqueça que figura nele, na pág. 7 com 'Cascudo e o Modernismo"'. Sobre o livro, afirmou que continuava a afirmar que modernismo não foi apenas em São Paulo, seu incontestável ponto de partida, mas que houve os processos desencadeados nas províncias, e anuncia o projeto de "O Modernismo nas Províncias", obra que não chegou a ser elaborada. Com tudo isto, ainda parabenizou o 
amigo pela recente obra a ser publicada; e fala do alívio "de não termos passado em vão sobre a terra":

Que os 'Andrades' o distraiam um pouco, são os meus votos. Não esqueça que figura nele, na pág. 7 com 'Cascudo e o Modernismo'. Continuo a sustentar que modernismo não foi apenas S. Paulo, seu incontestável ponto de partida. Houve as províncias. Creio que meu futuro livro será ' $O$ Modernismo nas Províncias', quando esse fenômeno ficará devidamente comprovado ${ }^{117}$.

Constitui para mim uma alegria muito grande saber que Você continua em forma, com um novo livro a sair pela Melhoramentos. Li a página de Brasília, apenas um resumo do que V. significa para a cultura brasileira.

Meu caro Cascudo: estamos velhos, mas uma glória nos cabe: a de não termos passado em vão sobre a terra, que é o destino da quase unanimidade dos que nascem. Demos o nosso recado. Continuamos a dá-lo. E o faremos, estou certo até á última hora, que Deus queira, venha tarde, muito tarde. De alguns esse recado tem a proporção do seu, de grandeza excepcional. Para outros, como eu, será modesto. Mas é sempre recado, mais válido ainda quando se trata de assunto do qual participamos. (JI, 5-XII-1975, Id. Ibidem, p. 146).

$\mathrm{Na}$ crônica que fora anunciada nesta carta, vemos que Inojosa reatualizou elementos por ele já anunciados num primeiro artigo também sobre seu velho amigo Luís da Câmara Cascudo, a primeira transcrição corresponde ao texto de 1968, já a segunda remete ao redigido em 1924, vejamos a seguir:

Em 1924, quando Câmara Cascudo, ainda acadêmico de Direito, surgia no Recife com os livros Joio e Histórias que o Tempo Leva, não somente o inclui entre os idealistas do modernismo brasileiro, como ressaltei, em artigo de jornal, que naquele rapaz de vinte e poucos anos estava um estilista - 'não se preocupa com a forma e a forma lhe sai correta' - rebelde às exigências de escolas - 'não se filiando a escolas, admira e acompanha os falangiários da renovação

\footnotetext{
${ }^{117}$ Araújo (1995) desenvolverá posteriormente o argumento que o Rio Grande do Norte conheceu não apenas o modernismo, mas também o regionalismo-tradicionalista-freyreano, de uma fórmula análoga a outros estados nordestinos, influenciados pela agitação cultural do Recife. Para o autor, seria possível estabelecer uma relação, guardando-se as devidas proporções, entre o papel exercido por Luís da Câmara Cascudo, no Rio Grande do Norte, e outros intelectuais como José Américo de Almeida na Paraíba, Gilberto Freyre e Joaquim Inojosa em Pernambuco, Mário de Andrade em São Paulo (ARAÚJO, 1995, p. 19).
} 
artística que se está realizando nos países civilizados' - (sic. Joaquim Inojosa - 'Luís da Câmara Cascudo' - Jornal do Comércio - Recife, 1924). (...) (INOJOSA, 1975a, p. 8).

Tem vinte e poucos anos de idade. Como é de notar, não se filiando a escolas, admira e acompanha os falangiários da renovação artística nos países civilizados. (...)

Pertence ao número dos escritores cuja vida se pode compreender através do que escrevem. Um estilo nervoso, agitado, brilhante, tumultuário quase, estilo de sensações. Não se preocupa com a forma, e a forma lhe sai correta. (...)

(...)

Filiado (aí está a confissão) aos modernistas, cinzela o 'Joio' e coleciona 'Histórias'. (INOJOSA, 1968, v.2, p. 66-68).

Cascudo voltará a falar sobre Os Andrades e os aspectos do modernismo (1975a), em carta de trinta de janeiro de 1976. Na mesma carta, tratou de suas impressões sobre Notícias Biobliográficas de Joaquim Inojosa (1975b), considerandoos documentos, testemunhas, vozes evocadoras das batalhas-romarias, de uma cruzada de fé cultural, abrindo caminho no imenso matagal do conhecimento. Obras que justificariam a trajetória e o mérito intelectual do amigo conhecido cinquenta e dois anos antes:

Na linha Pirangí, praia ao sul de Natal, reli OS ANDRADES E OUTROS ASPECTOS DO MODERNISMO, os discursos na Academia Carioca de Letras e a NOTÍCIA BIOBLIOGRAFICA, roteiro da viagem vital, destemorasa e vibrante, do menino de Tambaúba-dosMocós à notoriedade nacional do Mérito. Conheci-o em março de 1924. Cinquenta e dois anos rodaram na quarta dimensão... Predestinação de pé-de-vento, levantado das margens do Capibaribemirim, sonorizando por três horizontes brasileiros, erguido e vivo no azul da Guanabara, tendo nos pés da Alma areias de todos os quadrantes percorridos e conquistados. Destino de lidador, desses velhos pilotos que morreram centenários tendo entre os dedos curvados a roda do leme invisível. Esses volumes, acompanhados por mim em Pirangí, são documentos, testemunhas, vozes evocadoras das batalhas-romarias, porque V. invariavelmente combate numa Cruzada de Fé cultural, sine obulos nec laus, por amor à Emoção do impulso 
criador. Não lhe deram caminho. Abriu-o no matagal. (...) (CC, 30-I1976, Id. Ibidem, p. 148).

Agradecendo a generosidade do amigo, explica o seu método de escrita, disposto entre uns "tarecos de documentos" com "alinhavos de prático de jornalismo", com o intuito "de que o tempo não sepultasse os episódios". Uma preocupação que Inojosa irá expor nesta carta de quatorze de fevereiro de 1976 é o que seria de seu acervo caso viesse a morrer de forma súbita; como não tinha ninguém que prezasse por sua memória, certamente, ia "tudo pra fornalha, pro lixo":

Você é gigante de várias naturezas: pelo que escreve, pelo que fala, pelo que diz, e pela generosidade. E nesta boca eu estou. Somente assim se explica a sua carta (...). Apreciação crítica de alto estilo revestida do manto da amizade. Juntei uns tarecos de documentos, como diria [Raul] Bopp; fiz um alinhavos de prático de jornalismo, a fim de que o tempo não sepultasse os episódios...Já viu Você o que aconteceu comigo se morro de um momento para outro? Sem pai, sem mãe, sem mulher, sem filho... Vai tudo pra fornalha, pro lixo. Pode isto acontecer, mas ao menos terei tirado o suco da fruta. Se houver tempo de escrever livros de memórias, tudo será ampliado, do contrário, a essência está aí. (JI, 14-II-1976, Id. Ibidem, p. 150).

O livro Notícias Biobibliográficas de Joaquim Inojosa, com 92 páginas, narrado em $3^{\text {a }}$ pessoa, traz uma síntese "da vida desse escritor, do ano de nascimento até os dias atuais". Na seção Iconografia, a obra apresenta retratos das várias fases de sua vida (característica também presente em quase todo o conjunto de sua obra a partir da publicação de O Movimento Modernista em Pernambuco), ao lado de estudantes, recebendo condecorações e homenagens, discursando e na convivência com autoridades intelectuais e políticas do Brasil. Na apresentação da contracapa, logo acima de um retrato de Inojosa em frente a um microfone, com papéis em punho, provavelmente numa tribuna, encontramos um indício desses anseios: "Esta notícia biobibliográfica mostrará em resumo o que tem sido a vida de Joaquim Inojosa, ora como advogado, ora como empresário, mas sempre jornalista e escritor, atividades que jamais abandonou desde as estreias de 1917 e 1920". A escolha da palavra "notícias" no título do livro não deixa de ser pertinente, de chamar a atenção por se valer de um vocabulário próprio do meio jornalístico, razão mesma da existência dos meios de comunicação, o que mobiliza 
um jornalista e que torna o seu trabalho interessante. A notícia é uma busca, mas também, uma construção jornalística. De acordo com Barros (2012), podemos pensar que ao ressaltar suas "campanhas", ao enumerá-las e publicá-las na forma de livros, reunindo os artigos de diferentes momentos de sua vida, Inojosa constrói-se como a própria notícia, ele é o fato (BARROS, 2012, p. 127-128).

Podemos perceber na passagem da carta de quatorze de fevereiro de 1976, supracitada, que Inojosa se preocupava com o legado de seus escritos e de sua biblioteca. Sobre este aspecto, Natália Barros (2012) nos mostra que percorrer alguns dos eixos de interesse, elaborados no pressentimento da morte, parece uma possibilidade significativa de construirmos outros significados sobre seu itinerário, as redes de sociabilidade, as ideias e interesses de Joaquim Inojosa, fundamentais para compreendermos suas estratégias de auto-representação. Porém, ainda parece-nos que podemos situar esse documento de encontro com a possível morte, esse registro de expectativa de finitude que mobiliza a escrita do escritor como uma maneira de exercer o poder (Id. Ibidem, p. 149).

A autora nos convida a pensarmos estas suas práticas como a de um lapidário, ou seja, um sujeito que se utiliza de equipamentos para modelar, lapidar pedras brutas. É o lapidário que dá brilho e fascínio às pedras que a natureza produz. Sem o trabalho do lapidário, a pedra não teria um centésimo do brilho que vemos. Embora não possamos esquecer que lapidar não é apenas destacar a beleza não revelada, dar brilho aos encantos escondidos, é também esconder as falhas, as fissuras, as imperfeições. De acordo com Barros, esta seria uma possibilidade de entendê-lo como um lapidário de si, pois a escrita constrói e delimita sua trajetória como intelectual modernista e como jornalista, crítico polêmico e atento à paisagem cultural do país. A escrita é seu equipamento. A sua produção bibliográfica, enfatizando principalmente o Modernismo no Brasil, e a carreira de jornalista são pedras brutas que mereciam o contínuo esforço em busca do seu brilho próprio. O Movimento Modernista em Pernambuco, a carta literária A Arte Moderna, O Brasil Brasileiro e os livros Notícias Biobibliográficas de Joaquim Inojosa e 60 anos de jornalismo seriam pedras raras, polidas e brilhosas, narrativas que inserem o autor como destacado protagonista do cenário cultural e político brasileiro, particularmente no Recife e no Rio de Janeiro (BARROS, 2012, p. 165; MATTOS \& GRINBERG, 2004, p. 27-50).

Nesta correspondência, Cascudo, em carta de vinte e seis de janeiro de 1977, irá agradecer ao amigo Inojosa pelo envio do fascículo comemorativo dos 50 anos de $A$ 
Arte Moderna e $O$ Brasil Brasileiro. Na opinião de Cascudo, esse manuscrito libertaria os "inevitáveis pesquisadores do século XXI, segunda metade, as exaustivas tarefas perquiridoras do Fato em sua realidade desenvolvida e sugestiva", pois avivaria "os marcos de posse", "demonstrativos da utilização inicial do terreno" por aquele que foi o divulgador do modernismo em Pernambuco:

\begin{abstract}
Gratas saudações pelo ensaio contendo A Arte Moderna, cinquentenário em 1974, e O Brasil Brasileiro, com meio século em 1975, avivando os 'marcos de posse', demonstrativos da utilização inicial do terreno, exibindo a sinalização situante. Fêz bem V. sacudir aos ares os foguetões comemorativos da velha campanha literária, mostrando, materialmente, a rica documentação inegavel. (...) V. pode divulgar as cicatrizes das escaramuças e duelos, historiando aos olhos leitores a violência dos golpes e a obstinação defensiva e possessória. Libertou aos inevitáveis pesquisadores do século XXI, segunda metade, as exaustivas tarefas perquiridoras do Fato em sua realidade desenvolvida e sugestiva. (CC, 26-I-1977, apud, ARAÚJO, 2012, p. 154).
\end{abstract}

Em uma rememoração quase proustiana, Inojosa informa a Cascudo que nada fazia a não ser tentar readquirir um pouco do tempo perdido. Tentava apontar para as futuras gerações o que fez junto à mocidade de seu tempo, pois ao contrário de uns e outros, não tentava abiscoitar as glórias alheias. Nesse sentido, o amigo potiguar teve sua parcela de contribuição, principalmente por, numa época como a de meados da década de 1920, conseguir, mesmo com tantas dificuldades de comunicação, se fazer visto, lembrado e admirado:

Parece que foi ontem: entusiasmo de moço, aquele nosso, mas de quem sabia que o destino verdadeiro estava em cultivar um ideal. Fui menos feliz do que V.: desvie-me da rota por alguns anos; e hoje em dia o que tento é readquirir um pouco do tempo perdido. Quero ir na esteira, embora distante, dos companheiros de geração que souberam dar o seu recado. Preocupo-me em apontar o que fizeram na minha área; o contrário de outros que tenta abiscoitar todas as 'glórias' alheias.

As edições cinquentenárias serviram para redocumentar uma atitude, divida entre vários. Você foi um deles. Como ocultar isto da história 
literária do nosso Brasil, do grande Brasil que ajudamos a construir com os gritos da nossa juventude inquieta, fogosa e corajosa?

Antes de tornar-se o grande Vulto da Pátria, Luís da Câmara cascudo preparou o seu próprio caminho, plantou as sementes que iriam frutificar esplendorosamente. Essa gente ignora que há cinquenta e tantos anos o jovem teria de servi-se da prata da casa para vencer no campo cultural sem diretrizes. Juventude de heroísmo a nossa. Sobretudo quando numa época sem comunicação, conseguia transpor as fronteiras da província e tornar-se conhecido na corte. Hoje tudo é fácil. Ouvem-se, pelo rádio, os espirros. Naqueles tempos, era preciso berrar. E nós berramos. Esta, a verdade (JI, 31-I-1977, apud, ARAÚJO, 2012, p. 155).

Nestas últimas passagens aqui apreciadas, vemos os interlocutores argumentarem que as obras de Inojosa seriam elementos demarcadores de fatos e documentos históricos do que "realmente" havia acontecido no que concerne à campanha modernista no Nordeste. Há de se fazer uma ponderação sobre esses termos pois, se tudo que aconteceu é igualmente digno da história, como poderíamos considerar um fato, ou uma sequência de fatos, mais importante que outros? Se a história não se interessa pela "originalidade" dos acontecimentos individuais, mas pelo que torna o acontecimento em evento, pode-se dizer que os fatos têm um caráter de organização naturalizador, onde o historiador encontrará um sentido pré-estabelecido; uma vez escolhido o assunto que é inalterável enquanto experiência do vivido, o esforço do trabalho histórico consiste justamente em "reencontrar" novos sentidos para essa possível organização dos fatos (VEYNE, 1998, p.42).

Não é pelo fato de Cascudo acreditar que Inojosa poderia "divulgar as cicatrizes das escaramuças e duelos, historiando aos olhos leitores a violência dos golpes e a obstinação defensiva e possessória”. Que tenha libertado "os pesquisadores do século XXI, segunda metade, as exaustivas tarefas perquiridoras do Fato em sua realidade desenvolvida e sugestiva", muito pelo contrário, para os historiadores do nosso tempo, é preciso justamente que desconfiemos dessa noção de documento defendida por Cascudo e Inojosa; que para a escola histórica positivista do fim do século XIX e do início do XX, será o fundamento do fato histórico, ainda que este resulte da escolha, da decisão do historiador, parece apresentar-se por si mesmo como prova histórica. A sua objetividade parece opor-se à intencionalidade do monumento, afirmando-se essencialmente como testemunho escrito. Essa concepção de documento, ou mesmo a 
renovação deste conceito por intermédio da Escola dos Annales e pelas sucessivas correntes historiográficas, não pode desviar o historiador do sua principal função: a crítica do documento, sendo o que for, ou por quem quer que tenha sido inventado enquanto monumento; porque o documento não é qualquer coisa que ficou por conta do passado, é um produto da sociedade que o fabricou segundo as relações de forças que detinham o poder frente ao contexto (LE GOFF, 2003, p.526-527; 535-536).

Devemos observar que as narrativas apresentadas até aqui são entendidas como narrativas fundadoras, instituidoras de um passado e instituídas em diferentes tempos, não são construções naturais. Foram e continuam sendo repetidas exaustivamente. $\mathrm{Na}$ década de vinte e nas décadas posteriores, foram construídas, reconstruídas e atuaram em prol de determinados interesses dos intelectuais envolvidos. Entendemos, tal qual Barros (2012), que as escritas, de diversos tempos, de variados sujeitos, de múltiplos tons trazidos por Inojosa no Movimento Modernista em Pernambuco e nas suas demais obras que se seguiram ao longo das décadas de 1960-1980, remetem a cumplicidades, potências e impotências. Que ele buscou construir uma linhagem comum que se pretendeu imutável no decorrer do respectivo recorte temporal; sendo acionada por Joaquim Inojosa na constituição de seu projeto intelectual. Ao rememorar este período de sua vida pública, Inojosa estabelece uma comunicação consigo mesmo e com os outros, construindo discursivamente um ponto de vista sobre si e sobre os acontecimentos vividos que contribuem para o seu autoconhecimento, sua autoexplicação e auto-justificação, num esforço contínuo de elaborar sua reconciliação com o passado, sua redenção no presente e projetar também sua visão de futuro para a cultura brasileira (BARROS, 2012, p. 137; 139).

Felicitando Inojosa pelo livro 60 anos de jornalismo (1917-1977) em carta de vinte e dois de abril de 1977, Cascudo confessará sua intenção de fazer um livro parecido com este pelos idos de 1978. Para nele, rememorar sua experiência jornalística iniciada em 1918, por intermédio de sua primeira crônica "assinada" na Imprensa (1914-1927), jornal mantido sob os auspícios de seu pai para as suas iniciações literárias. Pois acreditava que dirigindo jornal, nunca foi jornalista, teria sido desde logo escritor fragmentário, carregando a cana-cortada do seu "pequenino canavial para os rolos da usina jornalística". Não teria sido como o amigo, eufórico, ágil, guerrilheiro e duelista como um D’Artagnan e Bergerac, volante de opinião pública, fundador de jornais; saudava o amigo de vida "tão sedutora e nobre pela incessante, inquieta, 
brilhante preferencia realizadora e dinâmica. Não esquecendo o ciclo industrial mineiro, tão vivo e simpático":

Sim senhor! 60 anos de jornalismo... Gloriosa servidão de viciado egrégio. 60 anos de bom combate, idealismo, entusiasmo colaborador, Esperança ascensional. No próximo $1978{ }^{118}$ baterei o firo dos 60, talqualmente V. outubro de 1918 , perpetrei a primeira crônica 'assinada' n' 'Imprensa', mantida por meu pai. Reporter vibrante e gratuito, era-o desde 1915. Mas, em bôa verdade, embora dirigindo jornais, nunca fui Jornalista. Fui, desde logo, escritor fragmentário, carregando a cana-cortada no meu pequenino canavial para os rôlos da usina jornalística. Não exerci, como V. o personagem eufórico e ágil, guerrilheiro e duelista como D' Artagnan e Cyrano de Bergerac, volante de opinião pública, fundador de jornais, inveja dos notáveis. (...) tenho alegria saudando este sessentão batalhador, de vida tão sedutora e nobre pela incessante, inquieta, brilhante preferencia realizadora e dinâmica. Não esquecendo o ciclo industrial mineiro, tão vivo e simpático. (CC, 22-IV-1977, apud, ARAÚJO, 2012, p. 156).

Agradecendo o elogio de "viciado egrégio" em carta de trinta de abril de 1977, Inojosa diria ser tão viciado como o amigo potiguar, do jornalismo, da imprensa livre, da boa leitura, bastava abrir os livros de Cascudo para se regalar. Informou que teria aproveitado palavras "da sua última e honrosa carta para justificar-me perante o público de estar recebendo homenagens pelos 60 anos de jornalismo":

Pois então sou um 'viciado egrégio'! ainda bem que do mesmo vício que pegou e não mais largou: o do jornalismo, o da imprensa livre, o do livro, o da boa leitura. Quando escrevo boa leitura, basta abrir livros do Cascudo. Regalo-me com eles. São uma festa para o meu espírito. (...)

- Cascudo querido: Aproveitei palavras da sua última e honrosa carta para justificar-me perante o público de estar recebendo homenagens pelos 60 anos de jornalismo... (...) (JI, 30-IV-1977, Id. Ibidem, p. 157).

\footnotetext{
${ }^{118}$ Sobre este aspecto é possível observar a respectiva matéria: n/a. Câmara Cascudo celebra 60 anos de jornalismo na imprensa potiguar. In: A República, Natal, RN, 20-X-1978. s/p.
} 
Conforme ressaltou Cascudo na carta que trata sobre o lançamento de 60 anos de jornalismo (1917-1977) (1978a), além de escrever na imprensa como jornalista e repórter, Inojosa fundou jornais e revistas no Recife e no Rio de Janeiro, e, em 1939, quando já morava na capital do país, criou a Editora Meio-Dia. Dentro das comemorações da carreira de 60 anos, publica em 1978, na apresentação daquela obra, que considerava "as raízes" de sua carreira, suas influências literárias e pessoais e comentou algumas das campanhas que o mobilizaram (BARROS, 2012, p. 124-125):

O jornalismo que exerço há sessenta anos (seis, apenas, de profissional: 1922-1927), tem as suas raízes fincadas num ideal de meninice, que atravessou a juventude e atingiu intato aos dias de hoje. Assumiu ou assume, por vezes, aspectos polêmicos, mas sempre na linha do respeito ao tema e ao homem, dentro da liberdade sadia que deve disciplinar e conduzir a imprensa, para que ela se imponha perante o público como força de cultura e equilíbrio social. Numa carta que me enviou (...) [o] universalmente renomado Luís da Câmara Cascudo, há seis dias apenas: - 60 anos de jornalismo... Gloriosa servidão de viciado 'egrégio'... 'Guerrilheiro e duelista como D’Artagnan e Cyrano de Bergerac...' (Carta de 22-4-977).

Podia enumerar algumas das campanhas em que me empenhei. Seria, porém, delongar-me sem maior interesse, salvo para os futuros pesquisadores da história da imprensa. Cito, contudo, sem pormenores, os entrechoques políticos de Pernambuco em 1922, o movimento modernista no Nordeste (1922-1930); a defesa da instituição do salário mínimo; a eleição presidencial de 1937; a pregação em favor do divórcio, pelo O Jornal, no ano de 1933; a de democracia orgânica para o Brasil, quando cheguei a escrever, enfaticamente, que 'a civilização de hoje não se constrói com oratória, mas com o trabalho' e que 'o Brasil precisa de abelhas e não de patativas'. Foi isso publicado em 17 de outubro de 1940 (Meio-Dia) e não vejo como pensar diferentemente nos dias atuais, quando, mais do que nunca, podemos observar que somente as abelhas constroem uma nação. Que a boa imprensa contribua para isso... (INOJOSA, 1978a, p. 18-19).

Podemos dimensionar a publicação dos artigos de Inojosa, as memórias do início de carreira, as concepções de imprensa e as percepções do país, no seu presente e no seu passado, como exercício simultâneo de busca por uma "genealogia", por um passado 
singular e linear e, ao mesmo tempo, a construção dessas mesmas aspirações por meio da escrita que indica, reivindica, alardeia esse lugar na história da imprensa, do modernismo, das lutas políticas do país. A escrita do experiente jornalista, do reconhecido escritor, delineou seu horizonte, verticalizando suas posturas políticas e individualizando sua relação com o meio cultural e intelectual do país, seus compromissos e seus combates em 60 anos de imprensa. Essa escrita ofuscou trajetórias e escamoteou certas escolhas, melhor dizendo, essa escrita escolheu, tomou partido na história e na memória do seu sujeito-autor (BARROS, 2012, p. 125-126).

$\mathrm{Na}$ última carta enviada por Inojosa a Cascudo, vemos a menção da programação das comemorações, dos sessenta anos do lançamento da carta literária $A$ Arte Moderna, da conferência que realizou em Natal, das fotografias de 1924 e 1984, da matéria "Inojosa visita Cascudo e recebe homenagens em Natal", publicada no dia 14 de outubro de 1984, no jornal natalense, A República; da alegria em ver que, passados tantos anos, os laços sentimentais da antiga e duradoura amizade continuavam os mesmos:

$\mathrm{Na}$ foto de 1924, dois brotos, elegantes e - para que negá-lo? bonitos. Na de 1984, passados sessenta anos, dois 'brotões'. Com esta marca generoso - a genrosidade do destino: Cascudo, glorificado no mundo da inteligência; Inojosa, numa desesperada tentativa de não morrer anônimo.

Reencontro de felicidade, que longe estávamos de perecer nos distantes idos do Recife. Mas que Braulio Sanches-Saez bem sentiu ao publicar aquela página de Caras y Caretas, de Buenos Aires, lá por 1925, chamando a atenção para os dois jovens cujas fotos a encimavam. Tudo a capricho nos dois destinos.

Por isto, posso confessar-lhe que um dos momentos mais felizes da minha vida, sobretudo nesta reta de chegada, foi o reencontro com Você, aquele fraternal abraço que bem definia, sessenta anos depois, os laços sentimentais atados quase às margens do Capibaribe, na época, nosso rio...

Ressaltei na conferência de Natal e o repito nesta carta: Você é a glória mais pura da cultura brasileira nestes sessenta anos do nosso conhecimento. E eu, o seu mais puro, isto é, mais leal admirador. Disto ninguém me tira (JI, 30-XI-1984, Id. Ibidem, p. 161). 
Ao que se vê, Inojosa buscou referendar nesta última missiva enviada ao velho amigo da campanha modernista que tudo que pôde realizar na época do desenrolar da campanha modernista no Nordeste, como em sua retomada memorialista 60 anos depois, ocorreu pela ajuda e pelo estímulo do velho amigo. A última carta da série foi redigida por Dhália Cascudo, a pedido de seu esposo, que devido a complicações de saúde, não pôde responder às declarações de afeto do estimado amigo:

O Luis adorou e eu achei maravilhosa. Sua alusão à fotos dopassado e do presente, uma delicia, sente-se o sabor da continuidade jovial do espírito vivo do Inojosa, predominando na envolvência de uma simpatia irradiante. Os anos não modificaram os encantos pessoais daqueles dois jovens, continuam bonitos, fisionomias expressivas, irradiando a riqueza de seu interior.

O reencontro das duas potencias, o abraço amigo e fraternal, inesquecível e marcante. Muito grata por tudo. O Luís, por meu intermédio, envia o mais afetuoso abraço.

Ele gostaria de lhe escrever diretamente, mas não podendo faze-lo, no momento, antecipa seu pensamento fraternal (CC, 11-XII-1984, Id. Ibidem, p. 162).

Os amigos não chegaram a finalizar a década, Cascudo veio a falecer em 1986 e Inojosa, um ano após. Ficaram essas reminiscências da antiga e duradoura amizade. A seguir, teremos um contraponto entre a correspondência do também amigo José Américo de Almeida, no que compete à crítica estabelecida por Inojosa a Gilberto Freyre e ao Movimento Regionalista no decorrer de 1968 a 1978. Embora exista no corpo das duas correspondências referências a queixa comumente apresentada aos seus dois interlocutores não ocorrerá, como podemos contemplar no capítulo anterior, uma apreciação mútua de questões intelectuais e afetivas em circuito fechado nestas cartas. Veremos no próximo capítulo que a correspondência estabelecida entre Câmara Cascudo e José Américo não fará referência à campanha modernista encabeçada por Joaquim Inojosa. 
5.4. Crítica a Gilberto Freyre e ao movimento regionalista na correspondência de Joaquim Inojosa com José Américo e Câmara Cascudo (1968-1978)

Segundo Neroaldo Pontes de Azevedo (1996), foi Wilson Martins quem, em seu Modernismo, em 1965, lançou dúvidas sobre a data da elaboração do Manifesto Regionalista escrito por Gilberto Freyre, em função do estilo ("a julgar pelo estilo, o autor praticamente reescreveu o seu trabalho") e da negligência de Gilberto Freyre em relação ao texto ("só tardiamente veio a dar-lhe importância de documento histórico"). Freyre realmente tenta, em obras posteriores à década de quarenta, trazer para si o mérito de ter chamado a atenção para a necessidade de renovação das artes nacionais, ainda antes de 1920. Mas quem denunciou publicamente a questão foi Joaquim Inojosa, em 1968, com o primeiro volume de O Movimento Modernista em Pernambuco, e em seguidas publicações, até a última, sobre o assunto, Sursum Corda (1981). Inojosa levantou toda a produção freyreana até o final da década de 70 para provar que o sociólogo sempre foi um ferrenho crítico do Modernismo e que só após a vitória deste movimento ele tentava se assenhorar do mérito. Ressalvado o caráter altamente polêmico das publicações de Inojosa, particularmente quando se refere ao Regionalismo, fica provado que o Manifesto, tal como se conhece, foi elaborado em 1952 (ALBUQUERQUE, 2011, p. 105; AZEVEDO, 1996, p. 152-154), conforme confessou Inojosa para José Américo em carta de vinte e cinco de março de 1968:

\footnotetext{
É que me preocupei em documentar. E através disto cheguei àquela conclusão de que foi antedatado para 1922 o Manifesto regionalista que Gilberto Freyre publicou em 1952. Embuste dos mais vergonhosos, se é possível admitir algum não vergonhoso (JI, 25-III1968).
}

Nas cartas escritas para José Américo de Almeida, Inojosa inicia a crítica a Freyre, contando que de 1923 por diante, Gilberto Freyre faria pregação sobre o Regionalismo e tradicionalismo, limitada a Pernambuco, mas que depois se denominaria de nordestina. Era uma pregação hostil ao Modernismo paulista, muito embora com este viesse a "reconciliar-se", pela maior influência do nacionalismo ou brasilidade dos modernistas, cuja bandeira Guilherme de Almeida implantaria no Teatro Santa Isabel, de Recife, ao ler, em novembro de 1925, sua conferência "Revelação do 
Brasil pela Poesia Moderna", seguida da leitura de "Raça", poema que ainda hoje consideram obra-prima (JI, 3-I-1966).

Na opinião de Inojosa, o pior:

(...) é que desde anos se vem convencendo que (o) Modernismo não chegou a atingir o Nordeste, cuja renovação literária se teria inspirado, tôda ela, tôdinha mesmo, em Gilberto Freyre. Ficou portanto, a nossa geração, ausente do grande movimento de 22. 'Ficou até agora', pois ainda ontem o historiador Mário da Silva Brito me asseverava que o meu livro, pelo seu documentário, modificava este sentido histórico.... (JI, 25-III-1968)

O que realmente desejava era desfazer a trama que levou o Itamarati a editar um livro - Quem é quem nas artes e nas letras do Brasil (1966) -, edição de alto bordo, em que se lia "tamanha barbaridade":

— 'Assim é Gilberto Freyre quem abre caminho para o advento do romance nordestino que nos dariam José Lins do Rêgo, José Américo de Almeida e Amando Fontes'. (pág. 302, Ed. 1966, do Dep-Cultural e de Informações do Ministério das Relações Exteriores).

Eis aí, meu caro, como se escreve a história. Ainda bem que é na biografia de Gilberto Freyre, que deve ter sido escrita por êle mesmo (JI, 25-III-1968).

Em João Pessoa, no dia oito de abril de 1968, José Américo de Almeida, em carta enviada, tecia certas considerações sobre esses acontecimentos. Comentava que Inojosa teria feito muito bem em situar em um livro tão bem construído, de longa pesquisa e elaboração magistral, o papel que teve como bandeirante do movimento modernista em Pernambuco. Principalmente, por ter colhido depoimentos de prestígio histórico que reconhecem esse esforço reconstrutivo, conferindo-lhe uma posição que não podia ser usurpada. Acreditava que o que outros fizeram foi num plano diferente, mais do que uma arte, uma cultura renovadora, cujo valor não podia ignorar. Entretanto, preferia não se envolver na discussão:

Vejo-me em dificuldades, como parte, para debater um aspecto da controvérsia, mas proclamo a importância de sua riqueza de informação e de seu método de expor. 
Sua moção é uma análise que exprime a velha solidariedade intelectual e um pensamento novo sobre uma obra já tão discutida (JAA, 8-IV-1968, apud, INOJOSA, 1980, p.32)

Vinte dias depois, Inojosa agradecia a carta enviada, considerando-a muito honrosa. Afirmando que apenas depôs e documentou o que realmente acontecera. Acreditava que talvez por esse motivo, Carlos Drummond teria escrito no Correio da Manhã que "seu livro contém muita coisa que vale a pena conhecer, como retrato intelectual dos anos 20 ”. Sobre essa "muita coisa", comentaria algo que não deixava de incomodar. Acabava de sair no Recife a $4^{\mathrm{a}}$ edição do Manifesto Regionalista de Gilberto Freyre, pelo Instituto Joaquim Nabuco de Pesquisas Sociais, mas sem o "1926" — simplesmente "Manifesto Regionalista". E, ainda mais grave em matéria de confissão de fraude: substituía o prólogo "Vinte e Cinco Anos Depois" da $1^{\mathrm{a}}$ ed., por um "novinho", intitulado "Prefácio do autor à $4^{\mathrm{a}}$ edição". De maneira que quem quisesse consultar para conferência ou estudo mais aprofundado, nada encontraria na $4^{\mathrm{a}}$ edição. E neste, Freyre se intitulava como o renovador da "década de 20", atribuindo aos rapazes da Semana de 22, simplesmente "pretensões a renovadores" da mesma década. Para isto, escrevera e criou na época, o "Regionalismotradicionalista-modernista":

\footnotetext{
Já neste instante, amplia a farsa: há de ser o renovador da literatura... nordestina?... não: brasileira, queiram ou não. Os modernistas de S. Paulo tiveram apenas... "pretensões a renovadores"; e quanto aos do Nordeste, nem se fala... é tudo "caudatório" (JI, 28-IV-1968).
}

Como fora anunciado na secção anterior, percebe-se na correspondência passiva de Cascudo o mesmo sentimento de Inojosa com relação a Gilberto Freyre. O divulgador do Modernismo em Pernambuco comentava em carta de vinte e um de julho de 1968 que sobre o famigerado "manifesto", como provou e confessava naquele instante, Freyre não era o renovador da literatura nordestina, como se intitulou durante dezenas de anos baseados em documentos falsos:

Sobre o caso do famigerado 'manifesto' regionalista, peço-lhe a atenção para o que escrevi na Separata que lhe envio por êste mesmo correio. Saiu-lhe uma $4^{\text {a }}$ edição - abril de 68 -, pelo Instituto Joaquim Nabuco de Pesquisas Sociais, sem o '1926' da capa das edições anteriores, numa clara confissão de fraude cometida. Agora passou a chamar-se simplesmente de 'Manifesto Regionalista' e não mais 
'Manifesto Regionalista de 1926'. Ora, manifesto regionalista qualquer regionalista pode escrever, e coisa melhor. Mas, no ano de 26, perante aquêle Congresso, com aquela precocidade, somente o poderia escrever Gilberto Freyre. E não escreveu como provei e o confessa agora, depois de impingir-se de renovador da literatura nordestina durante dezenas de anos, baseado em documentos falsos, por antedatados. (JI, 21-VII-1968, apud ARAÚJO, 2012, p. 110).

A separata a que faz menção no respectivo fragmento trata-se de No Pomar Vizinho... (1968b), veremos que a mesma já estava disposta como um dos capítulos decorrido entre as páginas 173 a 271, do primeiro volume do Movimento Modernista em Pernambuco; ao que parece, seu interesse era mais divulgar a respectiva crítica que mesmo a obra em seu conjunto, usava o alto preço dos livros no país para a elaboração da mesma:

\footnotetext{
O alto preço dos livros, atualmente, leva-me a editar, numa separata, para mais fácil divulgação, o capítulo que, no $1^{\circ}$ vol. de ' $O$ Movimento Modernista em Pernambuco' se refere às fraudes literárias do escritor Gilberto Freyre. Isto é, aquelas páginas que provam haver o autor de 'Casa Grande \& Senzala' antedatado, para o ano de 1926, o ‘manifesto' lido em 1951 e divulgado em 1952, sob o pomposo título de MANIFESTO REGIONALISTA DE 1926 Edições Região Recife 1952 (INOJOSA, 1968b, p. 3).
}

Frente aos elementos apresentados, é possível concluir que a participação de Joaquim Inojosa no movimento modernista se deu praticamente no âmbito da divulgação, em um contexto de produção jornalística. As suas cartas endereçadas a Câmara Cascudo, a partir de 1968, permanecem nessa perspectiva. Os seus livros publicados no intervalo entre 1968 e 1984, além das colaborações a O Jornal, do Rio de Janeiro, revelam o interesse pela notícia, pela fixação da sua imagem como modernista de primeira hora e pela polêmica. Em carta de três de março de 1974, reitera sua obsessão (ARAÚJO, 2012, p. 79):

Não houve espaço para que eu citasse ainda o seguinte: o 'Jornal do comércio', do Recife, reiniciou, em 1928 e até Outubro de 1930, a página literária que eu fundara em 1924. Pois bem, durante os três anos da segunda dentição, nem uma só palavra sobre Regionalismo, 
Gilberto Freyre ou movimento regionalista ou falecido Congresso Regionalista. Entanto, de Modernismo tratava sempre e muito sobre ele publicava (JI, 3-III-1974, Apud, ARAÚJO, 2012, p. 138)

Com relação às participações de Câmara Cascudo e Gilberto Freyre no movimento cultural da época, talvez seja interessante retomar a avaliação de Mário de Andrade sobre o Modernismo, para verificar não tanto diferenças entre eles, mas convergências de pontos de vista relativos ao estudo de formação nacional (ANDRADE, 1978, p. 243). Não interessa identificar o desejo desses autores em direção ao cânone modernista. Importa identificar se eles, participando de um estado de espírito revoltado e revolucionário que não era apenas brasileiro e sim mundial, tiveram uma "atitude interessada diante da vida contemporânea". Em carta de dois de novembro de 1973, o folclorista potiguar se encarrega de elogiar o trabalho documental de Joaquim Inojosa, mas os seus comentários parecem advertências sobre o anacronismo do amigo. Neste sentido, chama a atenção sobre o fim de um processo que poderia corresponder ao que Mário de Andrade chamava de espírito destruidor (ARAÚJO, 2012, p. 80-81):

O MOVIMENTO continúa contemporâneo e provocador de duelos entre derradeiros Mosqueteiros do Modernismo, que envelheceu e caiu do galho, como a camélia. Mesmo em S. Paulo já não justifica senão as reminiscências, onde os Mortos estão presentes e dominadores, até falando o que não pensaram (CC, 2-XI-1974, Apud; ARAÚJO, 2012, p. 133).

Câmara Cascudo parece comungar com a tese marioandradiana de que a "destruição continha os germes da atualidade e era uma convulsão profundíssima da realidade brasileira, o que permitiria compreender o surgimento de figuras 'construidoras' como José Lins do Rêgo" (ANDRADE, 1978, p. 242). Essa tese se reflete na mesma carta acima citada, parecendo no momento como a mais importante da correspondência analisada, dado seu caráter de síntese e lucidez, como se percebe no seguinte período, crucial para o entendimento do processo (ARAÚJO, 2012, p. 81): “Bem surpreendente que o MOVIMENTO, reformador e libertário na Europa, haja exercido no Brasil o processo revigorador da valorização nacionalista, do Brasil caboclo, diário, real, comum. Passado o vagalhão eufórico, o esforço foi vêr o quotidiano nacional" (CC, 2-XI-1974, Apud; ARAÚJO, 2012, p. 133). 
Noutra missiva, sem data, Cascudo mantém o tom conciliatório, mas lúcido, que sustenta a noção de um movimento formado de pluralidades, ou seja, sem o sectarismo demonstrado por Inojosa com relação a Freyre:

A SEMANA DE ARTE MODERNA será um complexo de tendencias determinantes, autônomas e colaborantes, como a confusão das raízes não implica a perturbação harmônica do colorido na flor. E todas têm razão na genética vegetal. A sua Motivação, Inojosa amigo, é defender a prioridade da primeira roseira no jardim posterior. Sua atitude ficará, como testemunhando as razões do jardineiro veterano $(\mathrm{CC}, \mathrm{s} / \mathrm{d}$, Id. Ibidem, p. 143).

Mesmo diante do posicionamento conciliador do amigo, o autor de Carro Alegórico (1973) ${ }^{119}$ não abriu mão, contudo, de permanecer no ataque incondicional ao seu inimigo ilustre, Gilberto Freyre:

(...) Mas, repito: deu V. uma lição ao 'suspeitoso' - para usar termo de Suassuana - senhor de casa grande e senzala. (...)

(...)

(...) Que danado de movimento regionalista-tradicionalista e a seu modo modernista foi esse, de 20 a 30, do qual ninguém falou na época?

Cascudo amigo: o que estou fazendo é defender o que realizou o nosso grupo, do qual V. fez parte, contra uma sórdida usurpação... alegórica. (JI, 3-III-1974, Id. Ibidem, p.138 )

Em carta de vinte e três de abril de 1978, vemos Joaquim Inojosa fazer uma última referência direta àquela polêmica. Questionava o amigo se já teria recebido $P a ́$ de Cal (1978b):

\footnotetext{
${ }^{119} \mathrm{Na}$ carta supracitada Inojosa, informará a Cascudo que aproveitou trechos de sua carta de dois de novembro de 1973 para recomendar Carro Alegórico ao público (Cf. JI, 3-III-1973, Id. Ibidem, p. 138). Em pesquisa realizada na Fundação Casa de José Américo de Almeida, encontramos uma carta escrita por José Américo em quinze de novembro de 1973, sobre a respectiva obra; desconfiamos que esta missiva não tenha sido enviada, pois, se Inojosa além da de Cascudo, fez referência a cartas de Menotti Del Picchia e Cassiano Ricardo, porque razão não teria utilizado um comentário tão positivo quanto o feito sobre o autor da Bagaceira: "Recebi seu CARRO ALEGÓRICO. Sempre polêmico, mas consagrado pelos testemunhos mais autorizados. Valoriza-se, além de sua participação pessoal, prestigiando e propagando o movimento essa excelente reconstituição histórica" (JAA, 15-XI-1973). Vemos que na apreciação que José Américo faz da respectiva obra, ressurge o mesmo argumento apresentado em carta de vinte oito de abril de 1968, o de não se posicionar frente à polêmica estabelecida por Inojosa.
} 
Deve ter recebido a minha $\underline{P a ́ \text { de Cal }}$. Último desafio, desta vez ao Instituto Joaquim Nabuco, que assumiu a paternidade de uma edição cinquentenária do Manifesto do Gilberto - 1926-1976. Tratando-se de uma autarquia federal, não pode cometer leviandade. Ou prova que tal documento foi escrito e lido em 1926, ou claudica e emprega mal os dinheiros públicos que lhes são confiados. Ao mesmo tempo que me servi do verbete da Biblioteca do Congresso dos Estados Unidos, para considera-lo a pá de cal definitiva. E nada mais direi sobre o assunto (JI, 23-IV-1978, Id. Ibidem, p. 160).

Não existe no corpo da correspondência de Cascudo e Inojosa carta que dê réplica ao devido assunto. Entretanto, como já foi aqui anunciado, esta não teria sido a derradeira obra sobre o tema, mas sim Sursum Corda! (1981). Na apresentação de Pá de Cal, vemos que Inojosa desenvolveu um argumento de apresentação, muito próximo ao exposto nesta carta endereçada ao autor de Civilização e Cultura:

$1^{\circ}$ - No volume $1^{\circ}$ do livro O Movimento modernista em Pernambuco (1968), demonstrei, documentada e irrefutavelmente, que era falso, quanto à data, o 'Manifesto Regionalista de 1926', do Sr. Gilberto Freyre, publicado no Recife em 1952 pelas 'Edições Região'. Levou a denúncia a que o Instituto Joaquim Nabuco de Pesquisas Sociais, dirigido, na época, pelo poeta Mauro Mota, imediatamente o reeditasse com o título modificado para 'Manifesto Regionalista', implicitamente reconhecendo a falsidade do '1926', enquanto o autor substituía por outro de linguagem disfarçada, o prefácio original.

$2^{\circ}$ - Eis que, surpreendentemente, o mesmo Instituto, já agora sob a direção de pai e filho - Gilberto Freyre, presidente do Conselho Diretor e Fernando Mello Freyre, presidente da Diretoria Executiva descuidando os zelos culturais de uma autarquia subordinada ao Ministério da Educação e Cultura, publica uma edição cinquentenária do aludido manifesto - 1926-1976 - (...)

$3^{\circ}$ - Na verdade, não podia o Instituto Joaquim Nabuco de Pesquisas Sociais assumir a responsabilidade de considerar 1926 um documento publicado em 1952, por pesquisadores, historiadores e críticos literários reconhecido como deste último ano, salvo contrariando a seriedade dos seus estudos e deles retirando o crédito merecido (...) (INOJOSA, 1978b, p. 13-14). 
Nos documentos analisados, além da tentativa de Inojosa de filiar José Américo de Almeida e sua obra A Bagaceira ao movimento modernista, dos arquivos da criação de Gente Viva, de Câmara Cascudo, e sobre as obras produzidas sob o esteio do Movimento Modernista em Pernambuco discutidas na correspondência com Câmara Cascudo entre 1968 e 1984; vemos, o ressurgimento de quatro personagens distintas: a) Joaquim Inojosa empreendendo um esforço descomunal para se perpetuar na história como o divulgador oficial do Modernismo no Nordeste; b) José Américo de Almeida e Luís da Câmara Cascudo, gozando os louros, a glória do reconhecimento nacional, assumindo plenamente o papel de sábios na velhice e ancorados na grande visão homogênea do Modernismo como o grande movimento literário e cultural do século XX no Brasil; c) Gilberto Freyre, que no olhar de Inojosa, realizou uma espécie de pecado por ter inventado um manifesto que, ao fim e ao cabo, teve a mesma função daquela que teria se não fosse uma invenção. Demonstra-se, então, que as quatro personagens (e mais do que elas, as suas obras) são tributárias do Modernismo mesmo quando se apegam à secular tradição regional que lhes dá identidade (ARAÚJO, 2012, p. 23-24).

Concordamos com Antonio Dimas (2004), ao afirmar que a importância da documentação apresentada por Joaquim Inojosa não abona a sua condenação à atitude de Gilberto Freyre; antes reconhece o mérito das contribuições do líder regionalista ao movimento cultural da época, tendo em vista que Inojosa não criou, não elaborou nem articulou um projeto. Sua função foi bem mais simples: a de transmitir o recado de uma novidade assimilada com susto. $\mathrm{O}$ contraste entre a atitude de Inojosa e a de Freyre reside na qualidade da elaboração intelectual de suas vivencias: enquanto Freyre criava mitos novos, Inojosa apenas os repetia. Para Dimas, Freyre não precisava lançar mão desse expediente, principalmente por ter criado uma das obras fundamentais para a compreensão da sociedade brasileira, reconhecida por intelectuais de vários espectros ideológicos e de várias latitudes, nacionais e internacionais (DIMAS, 2004, p. 19-20).

Neste aspecto Pallares-Burke (2005), reforça o argumento supracitado quando afirmou que o que ficou conhecido como Manifesto Regionalista de 1926 efetivamente não foi produzido enquanto tal nessa época, mas só tomou forma em 1952, no entanto, muitas manifestações de Freyre entre 1924 e 1926 podem ser vistas como parte de um claro, contundente e nada convencional manifesto regionalista em composição. Na concepção da autora, tal qual foi sugerido com grande perspicácia por Antonio Dimas, de várias fontes - dos pequenos artigos de Freyre publicados na imprensa diária, dos longos artigos escritos para o Livro do Nordeste de 1925, e mesmo do próprio espirito 
do livro que organizou - pode-se extrair uma "declaração de princípios" do respectivo projeto cultural (PALLARES-BURKE, 2005, p. 232-233).

A rivalidade intelectual e política, sem dúvida existente, não se exercitava sem o debate e não impedia o desenvolvimento de sólidas "amizades intelectuais", uma sensibilidade formada por afetividade e cumplicidade de projetos. O exemplo da correspondência entre Luís da Câmara Cascudo, Joaquim Inojosa e José Américo de Almeida é ilustrativo da importância deste lugar de sociabilidade que prolongava os encontros dos salões, das viagens e dos festivais, constituindo-se como no cotidiano da vivência intelectual, em distinção a seus momentos mais extraordinários (GOMES, 1993, p. 67-68; SIRINELLI, 2003, p.248).

A partir daí, as páginas dessas cartas testemunham a história da amizade entre esses participantes do Modernismo. Os documentos registraram estratégias de divulgação da arte moderna, dissenções nos grupos, comentários em torno da produção literária ocorrida no calor da hora. Adentraram no diálogo epistolar aqui analisado outros atores do Modernismo, redivivos, com suas fraquezas morais e potencialidades, examinados com paixão ou criticados cruamente. Entre a cena e os bastidores, a história do Modernismo se enriquece, perdendo a fixidez livresca. A sociedade brasileira vive nas ações e palavras dos interlocutores, homens de letras e intelectuais formadores de opinião (MORAES, 2001, p.14). 


\title{
6. Capítulo V:
}

\section{CONGRESSO REGIONALISTA DO NORDESTE - “QUE TENHO EU COM ELE?"}

a correspondência entre Câmara Cascudo, Gilberto Freyre e José Américo de Almeida (1922-1978)

\begin{abstract}
Quanto ao Congresso... que tenho eu com ele? As suas ideias ficaram justinhas na minha cabeça. Como se diz por aqui - direto que nem dedo em venta. (...) (CC, 12-X-1925, apud, CASCUDO, 2010a, p. 72).
\end{abstract}

Tendo como referência o estudo de Azevedo (1996), só se poderá falar de um movimento regionalista na década de 1920 em Pernambuco se considerarmos a criação, em 1924, do Centro Regionalista do Nordeste, que arregimentou um número considerável de intelectuais. Na opinião do autor, têm-se multiplicado os enganos quando se trata de definir a história e as atividades do Centro Regionalista do Nordeste, não se excluindo desses enganos nem mesmo a data de sua fundação ou o seu período de sobrevivência.

As dúvidas existentes ainda pairam quando se trata de definir a quem se deva atribuir a iniciativa da fundação do Centro (AZEVEDO, 1996, p. 143). Inojosa no Movimento Modernista em Pernambuco (1968a), afirmou que

\footnotetext{
Em 1925, fundou-se o Centro Regionalista, na residência particular do Prof. Odilon Nestor, sem maiores repercussões. Em fevereiro de 1926 realiza-se o $1^{\circ}$ congresso Regionalista do Nordeste, de menor repercussão ainda e dissolvia-se o Centro (INOJOSA, 1968a, v.1, p. 207).
}

Já Freyre, em discurso proferido em 1936, e reproduzido em Região e Tradição (1968), coloca a data de fundação para 1924, também atribui a autoria a Odilon Nestor mas, contrário a Inojosa, considerou um fato histórico relevante para a História intelectual do Nordeste:

Há doze anos foi você [Odilon Nestor] quem fundou em sua casa de Paissandu, sem medo ridículo, em volta de uma mesa de chá com sequilho e bolo de goma, aquele saudoso 'Centro Regionalista do 
Nordeste', para defesa das tradições regionais; 'Centro' que um dia será talvez considerado histórico (FREYRE, 1968, p. 261).

A ideia de realizar-se um Congresso já constava no Programa do Centro Regionalista do Nordeste, elaborado por Moraes Coutinho, e discutido e aprovado na reunião de cinco de março de 1924. Mas é na reunião de três de março de 1925, em seguida a uma proposta de dissolução do Centro, encaminhada por Gilberto Freyre, que Moraes Coutinho sugeriu a realização do Encontro, cumprindo-se assim uma das propostas do programa da associação. Na mesma reunião, aprovada com entusiasmo a ideia, fica nomeada a comissão encarregada da organização das teses a serem discutidas: Carlos Lyra Filho, Moraes Coutinho e Gilberto Freyre (AZEVEDO, 1996, p. 151)

\subsection{A relação de Câmara Cascudo com o regionalismo-tradicionalista-nordestino de} Gilberto Freyre: embates teóricos no campo da História e das Letras

Retomaremos agora alguns aspectos do debate em torno da associação ou não da obra de Câmara Cascudo ao regionalismo-tracionalista-nordestino, idealizado por Gilberto Freyre, já anunciado por intermédio do segundo capítulo desta tese ${ }^{120}$. Na argumentação apresentada por Francisco Firmino Sales Neto (2008), os estudos de Araújo (1995) e Ferreira (2001) reatualizariam as teses sobre a relação de Cascudo com o modernismo levantadas por Veríssimo de Melo, aspecto que na opinião de Sales Neto, silenciou durante muito tempo a relação de Cascudo com o regionalismo:

A exemplo de Veríssimo de Melo, Humberto Hermenegildo silencia o Cascudo regionalista. Muito embora faça constantes referências ao regionalismo e a Gilberto Freyre, em livros que versam sobre o pensamento de Cascudo, Hermenegildo o faz somente para acentuar os 'raros momentos' de sintonia que ele percebe entre os dois escritores. Por exemplo, quando Hermenegildo elenca as notícias sobre o regionalismo nos jornais locais é apenas para mostrar que essas notícias não estão diretamente relacionadas a Cascudo. Para Hermenegildo, Cascudo seria apenas um 'regionalista de ocasião', isto é, Cascudo teria tratado de assuntos regionais apenas esporadicamente

\footnotetext{
${ }^{120}$ Para tanto, verifique as ressalvas feitas na nota 45 da respectiva tese.
} 
e porque estava preso a um[a] província, onde o regional fazia parte da realidade cultural.

(...)

As idéias de Humberto Hermenegildo não se restringiram a ele, ressoaram com os trabalhos de seus 'orientandos', em especial, com José Luiz Ferreira, que desenvolveu uma dissertação de mestrado, também na área das Letras, sobre tema semelhante: Modernismo $e$ tradição: leitura da produção crítica de Câmara Cascudo nos anos 20. Ferreira mostra, na sua dissertação, como o envolvimento de Câmara Cascudo com o modernismo teria pautado toda a produção cascudiana dos anos 20 e levado o crítico literário a um forte apego pela tradição, notadamente, a tradição cultural sertaneja, que estaria sendo deturpada pela modernidade. Assim como Hermenegildo, as relações que Ferreira estabelece com o regionalismo foram utilizadas para provar que Cascudo não esteve próximo ao Movimento Regionalista- Tradicionalista nem ao Centro Regionalista do Nordeste (SALES NETO, 2008, p. 72; 75).

Sales Neto (2008) enfatiza em sua obra a relação de Cascudo com o regionalismo tradicionalista, estabelecendo uma crítica aos autores anteriores; argumentou que esses estudos reduzem a atividade intelectual de Câmara Cascudo a sua relação com Mário de Andrade. Com efeito, exploram os referidos anos de 1924, 1928 e 1929 e abdicam do direito - para não dizer dever - de problematizar as múltiplas faces do Luís da Câmara Cascudo crítico literário, quais sejam, sobretudo, a sua aproximação com o movimento regionalista-tradicionalista-nordestino; além do fato de não historicizarem a época, pensando a década como um bloco homogêneo, cujos anos citados é que explicariam todos os eventos e as circunstâncias vividas por Cascudo naquele tempo (SALES NETO, 2008, p. 27).

Araújo (2011) não nega a aproximação de Câmara Cascudo com Gilberto Freyre, demonstrando, por exemplo, que Cascudo era leitor assíduo dos artigos numerados do sociólogo pernambucano ${ }^{121}$, a série de cem artigos escritos, iniciados quando o Freyre ainda residia nos E.U.A (ou, mais precisamente noventa e nove, porque o n. 28, por lapso de numeração não existe), publicados no Diário de Pernambuco, entre vinte e dois de abril de 1923 e quinze de abril de 1925, e republicados nos dois volumes de Tempo de Aprendiz (1979). Existem nesses artigos dois filões de ideias

\footnotetext{
121 Este aspecto se comprova na carta escrita por Cascudo a Freyre em seis de junho de 1925, na passagem: "É inútil dizer que tenho lido os seus artigos no Diário". (CC, 6-VI-1925).
} 
importantes. O primeiro diz respeito à crítica do Futurismo, ou ao Modernismo. O segundo constitui o núcleo de preocupação dos artigos: ou seja, a defesa da tradição e dos valores regionais (AZEVEDO, 1996, p. 132). Sua ressalva é feita em torno da ideia de que tão expressiva amizade não autorizava, contudo, a aproximação de forma mecânica às perspectivas dos dois autores sobre 0 movimento regionalista tradicionalista nordestino e sobre o modernismo, naquele momento específico de agitação literária e cultural, pois compreende que nem Câmara Cascudo tinha as características do líder pernambucano, nem pode ser considerado um discípulo seu, como se dizia sobre José Lins do Rêgo (ARAÚJO, 2011, p. 88-89) ${ }^{122}$.

Para Ferreira (2011), da mesma forma que Gilberto Freyre em Pernambuco, Câmara Cascudo também comandou, guardando-se as devidas proporções, nos anos de 1920, uma discussão intelectual na cidade de Natal, a qual foi responsável pelo debate em torno das ideias modernistas e esteve atrelado a estas o consequente debate que envolvia as posições conservadoras. Tal debate não ficara imune também às questões ligadas ao regionalismo, pois, seja para aceita-las ou não, o assunto se fazia presente nessas discussões, já que a capital potiguar retomava, diretamente ou não, os acontecimentos que se davam em Recife, bem como em outros centros como o Rio de Janeiro, capital da república na época. $O$ autor ainda argumenta que não se pode esquecer que Cascudo presenciou bem de perto toda a articulação em torno do regionalismo, uma vez que ele frequentou a capital pernambucana, na qualidade de estudante do curso de Direito, entre os anos de 1924 e 1928, e estabeleceu vínculos de amizade e de discussão intelectual com vários dos participantes daquele movimento (FERREIRA, 2011, p. 50).

Segundo Ferreira (2008), ainda sobre os acontecimentos culturais referentes à cidade do Recife, é importante destacar alguns aspectos vivenciados pelo escritor norterio-grandense, que foram registrados em sua correspondência com Mário de Andrade. Fora da cena pública e protegido pelo sigilo da correspondência, o potiguar revelou ao amigo paulista sua opinião sobre aquele ambiente intelectual. Para o autor, as cartas revelariam, também, a falta de interesse de Câmara Cascudo pelo regionalismo, principalmente quando o assunto é o I Congresso Regionalista, acontecido em $1926{ }^{123}$.

\footnotetext{
${ }^{122} \mathrm{Na}$ nota 7 do referido estudo, o autor buscou ratificou o argumento, que a nosso ver parece soar como réplica às proposições realizadas por Sales Neto. Cf. (ARAÚJO, 2011, p. 91).

${ }^{123}$ Embora o contexto do debate das teses regionalistas ocorra no ano de 1925, o I Congresso Regionalista do Nordeste só veio a ocorrer entre os dias 07 e 11 de fevereiro de 1926 (Cf. AZEVEDO, 1996, p. 151; INOJOSA, 1968b, p. 57; SALES NETO, 2008, p. 154).
} 
Ferreira reforçou seu argumento com a respectiva passagem da carta escrita por Cascudo em vinte e dois de agosto de 1925 (FERREIRA, 2008, p. 92-93):

\begin{abstract}
Remeto um convite para o Primeiro Congresso Regionalista do Nordeste. Se V. não tem tempo de rabiscar em cima de alguma tese, assinale uma ou umas. No mínimo como curiosidade pelo inédito brasileiro. (...) (CC, 22-VIII-1925, apud, CASCUDO, 2010a, p. 55).
\end{abstract}

Em resposta ao amigo, Mário de Andrade, declarou-se "besta de entusiasmo", esclarecendo, no entanto que: "Em tese sou contrário ao regionalismo. Acho desintegrante da ideia de nação e sobre esse ponto muito prejudicial pro Brasil já tão separado". Referiu-se à noção de regionalismo dominante no período anterior ao modernismo - "Além disso fatalmente o regionalismo insiste sobre as diferenciações e as curiosidades salientando não propriamente o caráter individual e psicológico duma raça porém seus lados exóticos. Pode-se dizer que exóticos até dentro do próprio país, não acha?" - e valorizou um sentido que seria útil ao que considera "abrasileiramento do brasileiro": "É certo no entanto que regionalismo bem entendido traz benefício grande sobre o ponto de vista da própria descrição dos caracteres gerais psicológicos e outros dum povo". Com tal esclarecimento, avaliou: “Acho o programa um pouco acanhado e além de regionalista regionalizante o que é um perigo" ${ }^{124}$. A seguir, contrapõe as teses do programa do congresso a sugestões que envia, ressaltando sempre a brasilidade e verificando que nas teses relativas à vida artística e intelectual o programa demonstra preocupação mais com lados práticos que propriamente ideológicos (ARAÚJO, 2012, p. 66-67; CASCUDO, 2010a, p. 64):

Entre as teses dos 'Problemas econômicos e sociais' ${ }^{125}$ vocês se esqueceram inteiramente do Brasil o que acho positivamente um erro.

\footnotetext{
124 Sobre esse aspecto, vemos Gilberto Freyre no artigo "Do bom e do mau regionalismo" (1924) justificar o seu posicionamento sobre o regionalismo; sendo neste aspecto, avesso ao argumento apresentado por Mário de Andrade a Câmara Cascudo: "Não me parece que seja mau o regionalismo ou o patriotismo regional cuja ânsia é a defesa das tradições e dos valores locais, contra o furor imitativo. Não me parece que semelhante corrente de sentimento ponha em perigo a unidade brasileira nas suas raízes ou nas suas fontes de vida. (...) O bom regionalismo está longe, do mau, que é o separatismo; que consiste na imposição dos interesses locais sobre os gerais. Este mau regionalismo já se tem feito sentir na política e na economia brasileira, com os mais lamentáveis efeitos". (FREYRE, 1924, apud, AZEVEDO, 1996, p. 221-222).

${ }^{125}$ O programa-convite enviado foi reproduzido por Neroaldo Pontes de Azevedo (1996), nele, as teses eram: "1. Unificação econômica do Nordeste. Ação dos poderes públicos e particulares; 2. Defesa da população rural. Habitação, instrução, economia doméstica; 3. O problema rodoviário do Nordeste.
} 
A primeira de todas as teses devia ser: Contribuição do Nordeste para a constituição da Brasilidade psicológica, econômico-social, linguística e artística. Pras pessoas que veem muito largo ou veem amorosamente como é meu caso, isto está implícito no programa geral. $\mathrm{O}$ malentendido nasceu de haverem mais noventa-e-nove pessoas que se ajuntaram à primeira. Noventa-e-nove malentendidos quase sempre é a porcentagem. Veja se corrige isso com tempo. Si eu pudesse estudar mais seria essa a tese que escolheria ou então furava o programa falando sobre o 'Conceito de regionalismo'. Na 'Vida artística e intelectual ${ }^{126}$ quase com a mesma intenção nacionalizante em oposição à regionalizante das teses teria incluído: Caracteres gerais psicológicos do Brasileiro refletidos ou organizados tradicionalmente nas artes nordestinas. II: Contribuições linguísticas do nordeste para a língua geral do Brasil (lexiologia, fraseologia, sintática, modismos expressionais). III. Folclore nordestino. Não vejo bem aonde poderia tratar disso nas teses do Congresso a não ser de folclore no tratar de festas e jogos tradicionais (MA, 6-IX-1925, apud, CASCUDO, 2010a, p. 66).

Mário de Andrade também chamará atenção para a predominância dos "lados práticos" em detrimento dos "ideológicos" questionando, portanto, o caráter do referido congresso. O seu programa se aproximaria mais de uma plataforma política de modernização regional aliada à defesa das tradições, deve-se reconhecer, do que de um programa literário próximo, por exemplo, a um manifesto artístico. Por isso, o missivista acrescenta ao final da carta no seu Post-scriptum, a promessa de envio de Pau Brasil, de Oswald de Andrade ${ }^{127}$, como em uma tentativa de alimentar "ideologicamente" o amigo com a nova e revolucionária estética da brasilidade. Finalizaria de modo cortês afirmando: "Porém de qualquer maneira que seja o

Aspecto turístico, valorização das belezas naturais da região; 4. O problema florestal. Legislação e meios educativos; 5. Tradições da cozinha nordestina. Aspectos econômico, higiênico e estético" (AZEVEDO, 1996, p. 159).

${ }^{126}$ De acordo com o programa referido na nota anterior, as teses relativas à "Vida artística e intelectual" foram: “1. Unificação da vida cultural nordestina. Organização universitária. Ensino artístico. Meios de colaboração intelectual e artística. Escola primária e secundária; 2. Defesa da fisionomia arquitetônica do Nordeste. Urbanização das capitais. Plano para as pequenas cidades do interior. Vilas proletárias. Parques e jardins nordestinos; 3. Defesa do patrimônio artístico e dos monumentos históricos; 4. Reconstituição de festas e jogos tradicionais" (Id. Ibidem, p. 159).

127 Em carta não datada Oswald informa a Inojosa o envio de cinquenta exemplares de Memórias Sentimentais de João Miramar, pedindo que enviasse alguns a Cascudo, que conforme informação do Mário era muito chegado a eles: (...) 'Não tendo a quem confiar a sorte de meu último livro 'Memórias'... mando-lhe cincoenta volumes para distribuição entre intelectuais daí. Não se esqueça de mandar um ou mais a Luiz da Câmara Cascudo, conforme informação do Mário, muito chegado a nós" (INOJOSA, 1968a, v. 2, p. 346-347). 
Congresso é interessantíssimo e desejaria estar aí" (ARAÚJO, 2012, p. 68; CASCUDO, 2010a, p. 66-67).

Na avaliação de Ferreira (2008), a carta de Cascudo escrita em doze de outubro de 1925, que deu resposta às críticas apresentados por Mário sobre a carta programa do I Congresso Regionalista do Nordeste, demonstraria que o autor potiguar tratou sem nenhum entusiasmo a questão e desfazia-se portanto a ideia de que ele seria um dos organizadores do evento; conforme parecia acreditar Mário (FERREIRA, 2008, p. 94): (...) "Quanto ao congresso... Que tenho eu com ele? As suas ideias ficaram justinhas na minha cabeça. Como se diz por aqui - direto que nem dedo em venta" (CASCUDO, 2010a, p. 72).

Na compreensão de Sales Neto (2008), este aspecto discutido por intermédio de Araújo (2012) e Ferreira (2008), demonstra que Cascudo não só conviveu com Freyre, e que tinha conhecimento dos aspectos da organização do Congresso, não significando que tenha se feito presente no evento ${ }^{128}$. Segundo o autor, não podemos esquecer outro aspecto muito importante presente ainda no trecho da carta de Mário de Andrade, citada anteriormente. Mário se referiu a Câmara Cascudo usando um pronome pessoal de tratamento no plural: "vocês", ao escrever "Entre as teses dos 'Problemas econômicos e sociais' vocês se esqueceram inteiramente do Brasil o que acho positivamente um erro". Sales Neto notou que Mário incluiu Cascudo entre os regionalista-tradicionalistas. Ou seja, Mário não estaria falando apenas com Cascudo, mas com todos os envolvidos no I Congresso Regionalista, que teriam se esquecido de explorar a ideia de brasilidade na primeira parte do plano de teses. Enfatizando que Mário de Andrade, o próprio autor que - nos dias de hoje - é usado para explicar o "Câmara Cascudo modernista", definiuo nesta carta, como regionalista. Por conseguinte, Sales Neto, acredita que a réplica de Câmara Cascudo a seu amigo é emblemática; demonstrando como a correspondência é um espaço de construção subjetiva. Ao responder aos referidos comentários, Cascudo se construiu como um autor modernista e procurou se afastar das ideias regionalistas difundidas pelo Centro Regionalista - às quais Mário de Andrade havia esboçado restrições. Teríamos aí um sujeito que se construiu da maneira como desejava ser visto

\footnotetext{
${ }^{128}$ Durante a realização do Congresso, a imprensa, particularmente o Diário de Pernambuco, o Jornal do Commercio e A Província, noticiaram o andamento das atividades, com alguns resumos dos trabalhos apresentados, constituindo, assim, fonte disponível e confiável para que se possa reconstituir o que foi o Congresso, segundo a ótica do noticiário da época (AZEVEDO, 1996, p. 157). É sabido, por exemplo, que Inojosa apresentou na separata No Pomar Vizinho... (1968), exaustivo documentário de todos os encontros realizados e que foram noticiados pelo Diário de Pernambuco e neste, não ocorreu nenhuma referência a Cascudo (INOJOSA, 1968b, p. 106-120).
} 
por seu interlocutor: Cascudo quis se mostrar (depois de ler os comentários do amigo paulista) como não sendo adepto do tipo de regionalismo proposto nas teses do I Congresso Regionalista do Nordeste. Conforme se pode observar, a partir daí, ele não tocará mais no assunto do regionalismo em suas cartas a Mário de Andrade (SALES NETO, 2008, p. 152-154).

Aqui não nos posicionaremos a favor de nem contra nenhuma das correntes interpretativas apresentadas. Pretendemos neste último capítulo, ao analisar a correspondência de Luís da Câmara Cascudo com Gilberto Freyre e José Américo de Almeida, demonstrar que Cascudo, mesmo tendo estabelecido uma rede de sociabilidade intelectual "modernista", não deixou de estabelecer contatos com uma rede de sociabilidade intelectual "regionalista". Buscamos aqui analisar o que estas cartas comunicaram diretamente - e de modo algum a comprovação de que Câmara Cascudo foi ou não modernista, teria sido ou não regionalista -, o que elas proporcionam subentender ou revelar dos seus interlocutores. Pois não é de se estranhar que tanto a personalidade de quem as remete como a de quem as recebe se revelem através das cartas. E quanto mais espontâneas, mais livres da censura consciente, tanto mais reveladoras serão de suas personalidades (RABELLO, 1978, p. 19).

Mesmo que as respectivas correspondências não estabeleçam um circuito fechado de diálogos e ideias entre os respectivos interlocutores, é possível, por intermédio de um cotejamento minucioso das fontes, remontarmos aspectos desta experiência regionalista e de sua relevância para a formação intelectual de Luís da Câmara Cascudo.

\subsection{A correspondência entre Câmara Cascudo e Gilberto Freyre (1923-1976)}

Antes de nos voltarmos a correspondência entre Cascudo a Freyre, gostaríamos de ainda realizar uma última incursão na correspondência de Mário e Cascudo para demonstrar que além da referência supracitada sobre as teses do I Congresso Regionalista do Nordeste, vemos que também ocorrem referências a Gilberto Freyre, assim como ao Livro do Nordeste (1979) ${ }^{129}$.

\footnotetext{
${ }^{129}$ A sete de novembro de 1925, como uma das comemorações dos seus cem anos de existência, o Diário de Pernambuco fez circular, sob o título de Livro do Nordeste, uma coletânea de trabalhos, definidos no artigo de apresentação como um "pequeno esforço de estimativa em torno de alguns valores mais característicos da região". São hoje raros os exemplares desta edição de 1925, mas o Arquivo público Estadual de Pernambuco fez publicar, em 1979, uma oportuna edição fac-similar, com uma introdução de
} 
Sobre Gilberto Freyre, vemos o registro em duas passagens na respectiva correspondência. A primeira delas em carta de nove de dezembro de 1925, Cascudo pede para fazer uma confissão a Mário de Andrade. Na opinião de Cascudo, o nível mental do Recife seria inenarravelmente baixo. Faziam versos para o salão. Havia passado dois meses em Recife, e deduziu que o "intelectualismo" recifense era unicamente elegante, "bebedor de chá, lambedor de sorvete, dançador de fox e guiador de automóvel". Havia exceções, fortuitas e raras como Carlos Gomes, Manuel Bandeira, Gilberto Freyre, Joaquim Inojosa, um Austro Costa. Cascudo achava esse seu ponto de vista quase ingratidão, tendo em vista que era aclamado por eles:

o nível mental de Recife é inenarravelmente baixo. (...) Fazem versos para o salão. $\mathrm{O}$ dia em Recife é de 4 horas o resto é silêncio. E passo em silêncio o seu escandaloso julgamento sobre o meu espírito. E, meu querido Mário, fiquei triste. Calculei pelo meu desnível julgado altitude o que, aos seus olhos limpos de inveja e plenos de saúde mental, deveria ser a gente do Norte... Passei dois meses em Recife com dinheiro, curiosidade e amigos d'alta sociedade. Deduzi o que vem a ser o 'intelectualismo' de lá. É unicamente elegante, brunido, bebedor de chá, lambedor de sorvete, dançador de fox e guiador de automóvel. (...) Com exceções (fortuitas e raras) estamos ainda na fase da interjeição. Fase do berro. Do guincho. Do Carlos Gomes em Guarani. Jamais em Condor. Os 'verdadeiros', los raros, vivem como esse maravilhoso M. Bandeira, um Gilberto Freyre e mais dois, cercados pelo ódio e pelo respeito de um mundozinho de literatelhos grasnadores. Olhe que é uma quase ingratidão minha. Sou festejado. Querido. Meio incensado. (...) Há em derredor de seu nome um grande respeito supersticioso. (...) Há neles a mania da 'escola'. Entretanto Austro Costa é poeta. Góes Filho é alma. Inojosa é atitude ${ }^{130}$. (...) (CC, 9-XII-1925, apud, CASCUDO, 2010a, p. 79-80).

Mauro Mota, diretor de arquivo à época, e um depoimento de Gilberto Freyre. A introdução de Mauro Mota e o depoimento de Gilberto Freyre, especiais para a edição fac-similar, trazem esclarecimentos importantes sobre a origem, a formação e o destino do Livro do Nordeste, carregando nos elogios mútuos e na identificação de "antecipações" ou "pioneirismos" (AZEVEDO, 1996, p. 165).

${ }^{130}$ Sobre este aspecto, vemos que Joaquim Inojosa tinha uma opinião muito próxima da apresentada por Cascudo nesta carta. No artigo "Mascates da Literatura", transcrito no segundo volume do Movimento Modernista em Pernambuco, temos os seguintes comentários: "Nesta cidade, as inteligências vagueiam em tôda parte; os moços de letras, imberbes, passeiam despreocupadamente em plena rua Nova; falam, excitados, a deshoras, nos 'cabarets'; sentam-se na 'Bijou', pagam os $\$ 700$ do creme baunilha e ocupam as cadeiras por duas ou três longas horas, a dizer mal dos companheiros; perseguem, no Moderno, com olhares e frases, as melindrosas gentis... (...) Há exceções e honrosas. Dessas não falo eu. Posso citar algumas, ou ao menos as mais conhecidas: (...) Gilberto Freire, deslocado neste meio que o critica, porque poucos que, como êle, estudem tanto e sejam dotados de cultura moderna e sólida; Austro-Costa, o único 
A segunda referência está presente em carta de trinta de dezembro de 1925. Nela, Cascudo comenta que enviou para Gilberto Freyre uma cópia do fragmento de uma carta em que Mário elogiava o Livro do Nordeste:

\begin{abstract}
Mandei para o Gilberto Freyre (organizador do álbum do $D$. de Pernambuco) uma cópia do período a respeito da publicação. O Diário havia publicado uma nota - breve trecho da carta do Sr. M. Bandeira - elogiando o autor d'igual nome e de lápis na munheca. E o Bandeira-poeta falava em V. Eu vivo espreitando as letras de seu nome. Se é de bem ajudo a queimar o foguete. Se é de mal... lasco o marmeleiro (CC, 30-XII-1925, Id. Ibidem, p. 82).
\end{abstract}

Esta última passagem em que Cascudo afirmou ter mandado "uma copia do período a respeito da publicação" se refere à carta enviada por Mário de Andrade em vinte e seis de novembro de 1925, onde o autor de Macunaíma fala sobre suas impressões iniciais a respeito da obra em questão:

Recebi sua carta de dez de outubro, recebi fotografias de coisas Iguarassu, e recebi finalmente o álbum comemorativo do Diário de Pernambuco. (...) E inda no álbum do Diário de Pernambuco vem uma rua de Igarassu vigorosamente riscada pelo M. Bandeira ${ }^{131}$, que encheu as medidas. E quem é esse M. Bandeira desenhista, hein? (...) o álbum tem muita coisa de interessante. (...) os desenhos e a coleção dos assuntos me interessou vivamente. Inda hei de dar pra você uma opinião mais exata quando ler o tal. (...) (MA, 26-XI-1925, Id. Ibidem, p. 75).

A passagem supracitada dá a entender que poderia ter havido uma carta ou outras em que Cascudo tenha tratado sobre o respectivo projeto editorial freyreano,

poeta dos novos; (...) Essas exceções não se misturam, nem mesmo na convivência pessoal diária, com o rebanho dos 'talentos imensos' que aí vivem, para quem quiser ver, nas colunas dos vespertinos, assimilando editoriais dos matutinos cariocas e depois impingindo-os em forma de sueltos..." (INOJOSA, 1968a, v. 2, p. 45-47).

${ }^{131}$ Em carta enviada a Manuel Bandeira no dia vinte e nove de novembro de 1925, vemos Mário fazer o seguinte comentário sobre a contribuição do amigo para o Livro do Nordeste: "tenho o prazer de comunicar-lhe que sobre os meus olhos caíram no Álbum do Centenário do Diário de Pernambuco uns versos de sua lavra, se me não engano intitulados 'Evocação do Recife' e que os li com atenção e carinho que me merece a alta personalidade de V.S. (...) Queira pois V.S. receber os parabéns efusivos daquele que se orgulha de o contar entre as pessoas de suas relações e toma a liberdade de oferta-lhe a mão divina”. (MA, 29-XI-1925, apud, MORAES, 2001, p. 256). 
tendo por fim, enviado ao amigo paulista a respectiva obra. O que se pode perceber pelas passagens apresentadas é que além do conhecimento e interesse de Cascudo pelo $I$ Congresso Regionalista do Nordeste, houve por parte dele a mesma afeição pelo Livro do Nordeste. Tomemos como comprovação desta hipótese os comentários de Gilberto Freyre, em carta não datada, sobre os livros Joio e Histórias que o tempo levam..., convidando por fim, Cascudo a escrever sobre os cem anos de vida de Natal, bem ao estilo dos artigos que compuseram o Livro do Nordeste:

\begin{abstract}
Há umas boas páginas mas no conjunto me parece um livro apressado que não justifica o subtítulo literatura e crítica. É antes, jornalismo posto em livro. Prefiro as Histórias onde há páginas bem interessantes como aquela sobre a morte do holandês ${ }^{132}$. Acho que a sua veia é antes histórica do que crítica. E é por isso que espero um trabalho sugestivo sobre estes cem anos de vida de Natal ${ }^{133}$. Não estranhará V. a franqueza - sabendo que sem ela eu não sou eu (GF, s./d.).
\end{abstract}

Embora esta carta não tenha sido datada, podemos afirmar que foi escrita em 1925. Sales Neto (2008), que inicialmente teve acesso ao respectivo documento ${ }^{134}$, quando este ainda compunha o acervo do Memorial Câmara Cascudo, hoje presente no acervo do Ludovicus - Instituto Câmara Cascudo, reforça a hipótese. Falta nela uma parte do texto. A carta foi escrita em papel timbrado com a indicação da comemoração do centenário de fundação do Diário de Pernambuco. Cotejando essa carta com outra missiva escrita por Cascudo em seis de junho de 1925 , e enviada a Freyre ${ }^{135}$, vemos que Cascudo fez referência a um tema que havia sido discutido por Freyre em carta anterior, podendo a respectiva carta ser de dezessete de março de 1925 (SALES NETO, 2008, p. 139):

\footnotetext{
${ }^{132}$ Neste aspecto, vemos que Freyre emitiu uma opinião próxima à de Mário de Andrade sobre as respectivas obras (Cf. MA, 26-IX-1924, apud, CASCUDO, 2010a, p. 36-38).

${ }^{133}$ Quando Freyre destacou estar esperando por "trabalho sugestivo sobre estes cem anos de vida de Natal", é preciso levar em consideração que na maior parte dos artigos publicados no Livro do Nordeste o limite cronológico sãos anos de 1825 e 1925. Não há outros registros na correspondência trocada entre Cascudo e Freyre referente ao referido projeto editorial. São desconhecidas as razões de Cascudo não ter se empenhado na elaboração do artigo (SALES NETO, 2008, p. 140-141).

${ }^{134}$ Posteriormente inclusa por Moraes (2010), como nota a carta de Câmara Cascudo escrita para Mário de Andrade em nove de dezembro de 1925, para explicar quem seria Gilberto Freyre e que tipo de relação estabelecia com Câmara Cascudo à época (CASCUDO, 2010a, p. 80, n. 73). Não conseguimos encontrar o respectivo documento na plataforma de dados do Ludovicus Instituto Câmara Cascudo, portanto, todas as menções feitas ao respectivo documento, tem por base o estudo de Sales Neto (2008).

${ }^{135}$ Esta carta e todas as demais enviadas por Luís da Câmara Cascudo a Gilberto Freyre pertencem ao Acervo da Fundação Gilberto Freyre.
} 
Cá recebi sua carta. Há uns três dias lhe escrevi enviando as letras do Sr. Bilden. Interessante é que sua carta de 17 de março veio chegar a 05 de junho as minhas mãos. O carimbo do correio d'aqui é desta data (CC, 6-VI-1925).

Através destas cartas, foi possível perceber como ocorreu a participação do Rio Grande do Norte nas comemorações do centenário do periódico. O Livro do Nordeste contou com a colaboração de dois norte-rio-grandenses ligados diretamente a Câmara Cascudo: Henrique Castriciano e Eloy de Souza. O primeiro escreveu um artigo sobre Nísia Floresta (CASTRICIANO, 1979, p. 138-139). O segundo por sua vez dissertou sobre os cantadores nordestinos (SOUZA, 1979, p. 66-67). Nesta carta, o artigo de Eloy de Souza foi um dos assuntos discutidos. Após a sugestão do tema para a elaboração do artigo, Freyre comentará com Cascudo que está impossibilitado de visitar a cidade do Natal e pede para que remetesse o artigo e quando o fizesse, mandasse o seu retrato e breve nota biográfica sua como dos amigos Henrique Castriciano e Eloy de Souza:

\footnotetext{
Parece-me difícil a ida aí. Peço-lhe o possível empenho (sic.) na remessa do artigo, que peço acompanhado de seu retrato e breve nota biográfica. Também notas biográficas de Eloy e Henrique Castriciano (GF, s./d.).
}

Em outro trecho da carta, vemos Freyre mencionar alguns aspectos do artigo de Eloy de Souza, solicitando a Cascudo que entrasse em contato com Eloy, questionando, se o mesmo daria autorização para realizar leves alterações no texto durante o processo editorial do livro:

Recebi do Eloy os trechos da conferência. Consulte-me sobre o seguinte: (1) si posso dar as vistas o título 'Os últimos cantadores do Nordeste'; (2) si posso eliminar os 'meus senhores e minhas senhoras' e dar assim um ar de artigo especial para o livro, pois a colaboração será só de inéditos. Estão bem interessantes as notas. (...) (GF, s./d.).

Sobre esse pedido feito por Freyre, vemos Cascudo esquivar-se, por não sentirse muito seguro de o encaminhar: 
tempo e olhadelas. Creio ter sido o próprio Eloy que lh'a enviou (CC, 6-VI-1925).

As respectivas cartas analisadas até este momento do texto não são as referências mais remotas na correspondência estabelecida entre Câmara Cascudo e Gilberto Freyre; temos ainda uma carta datada de vinte e cinco de junho de 1923, demonstrando que o diálogo com Gilberto Freyre antecedeu o contato com Mário de Andrade. Freyre, ao se deparar com a leitura de um artigo de autoria de Cascudo que tratava "do seu ponto de vista e dos hábitos intellectuaes", escreveu em agradecimento. Pela data da carta, podemos afirmar que se trata do artigo "Cigalhos... a propósito do numerário de Gilberto Freyre", publicado em quinze de junho de 1923 e que compunha a série "De Recife", divulgada no jornal A Imprensa:

\footnotetext{
Vi com muita surpresa seu gentil e interessante artigo. Tão habituado estou à antipathia dos litteratos da terra - o que muito me honra - e à indiferença dos demais - geralmente honrosa - que é surpresa toda a nota discordante. No seu caso, independente do assunpto,foi um prazer a leitura do artigo pelo que de interessante renda do ponto de vista e dos hábitos intellectuaes do autor (GF, 25-VI-1923).
}

No artigo, Cascudo comentou que havia amanhecido sem ideias, e como não conseguira tê-las, fora busca-las em outros autores. Após muita procura, melancolicamente, acabara indo ler jornais, encontrando no "Diário de Pernambuco uma série de crônicas sob títulos numerados. Li até a $8^{\text {a }}$ (...). Li e, para melhor dizer, andei vagamente invejoso do cronista [Freyre]". Este aspecto demonstra que, mesmo antes de ir residir no Recife, Cascudo já percebia em Freyre um modelo de escritor e um estilo peculiar de escrita. Fato que fica ainda mais explicitado diante da seguinte afirmativa: “Gilberto Freyre é um... é melhor dizer que é ele mesmo. Não encontrei sósia mesmo transplantado, para o equilíbrio comparativo. Leu, viajou, e melhor, sabe ler, viajar e ver. A primeira dessas virtudes é rara no Brasil”. Essas mesmas ideias freyreanas, seriam ainda elogiadas no ano de 1924 (CASCUDO, 1923; SALES NETO, 2008, p. 120-121).

Observador sutil, Cascudo foi capaz de captar a teatralidade e os traços pitorescos dos desajustes do cosmopolita na província, envolvido num esforço de revitalização de tradições. Numa breve nota publicada no jornal A Imprensa, da mesma 
série intitulada "De Recife", temos "A bengala de Gilberto Freyre". Neste artigo, aquele objeto é imaginado como um bastão de ébano, com um cabo de Limoges, como um símbolo de autoridade e comando no estilo de Brummel. O símbolo de um dândi, que na realidade manipulava um stick de madeira fino, flexível e sibilante, espécie de chibata de antigo professor escolar, um pouco incongruentemente apoiado no velho solo natal (CASCUDO, 1924; GIUCCI \& LARRETA, 2007, p. 229-230).

Dentro do debate sobre a associação de Câmara Cascudo ora como modernista, ora como regionalista, o artigo "A Bengala de Gilberto Freyre" é tomado como ponto nevrálgico. Tomemos inicialmente os argumentos apresentados por Araújo (2012). Segundo o autor, a caracterização descrita tem o propósito de acentuar o traço localista e irônico, em contraposição ao cosmopolitismo esperado de quem assimilou a tradição ocidental, europeia, uma vez que a personagem central da crônica havia, como se sabe, retornado do exterior. Para Araújo, a crônica de Cascudo apresenta dificuldades em sua compreensão por se tratar de um texto impressionista, sem o devido distanciamento temporal e crítico. Escrito no calor da hora e sob os influxos da participação na vida literária do momento, geraria dúvidas quanto ao posicionamento do seu autor com relação às ideias freyreanas daquele tempo. $\mathrm{O}$ autor se pautou no argumento apresentado por Ferreira (2008) de que essa crônica revelaria certo distanciamento entre os dois intelectuais nordestinos, fato que seria motivado pelas diferenças entre os propagadores dos dois movimentos (modernismo e regionalismo) que disputavam a hegemonia cultural. Considerando a ironia predominante no texto, talvez seja possível reconhecer aí mais uma disputa de liderança do que diferenças de posicionamentos explícitos sobre os dois movimentos (ARAÚJO, 2012, p. 69-70):

Na verdade, pensamos que a crítica feita por Câmara Cascudo já tinha, de certo modo, uma implicação, pois, ao afirmar que a bengala expressava melhor o estilo do autor do que seus artigos e crônicas, ele não entra no mérito do debate intelectual proposto por Gilberto Freyre, debate esse que, aos poucos, ia ganhando adeptos entre aqueles que o admiravam na cidade do Recife e, depois, entre vários outros seguidores pelo Nordeste afora, (...) Sabemos que Câmara Cascudo não chega a ser um entusiasta das idéias de Gilberto Freyre, mesmo entendendo que a questão regional era um elemento fundamental dentro do processo de brasilidade que grande parte da intelectualidade buscava naquele momento. Essa afirmação se faz tendo em vista que nenhum dos textos publicados por Câmara 
Cascudo nesse período faz referência direta às articulações que envolviam Gilberto Freyre, no sentido de permitir a identificação de um vínculo com o grupo liderado pelo pernambucano ou na defesa do movimento regionalista iniciado naquele período. Por outro lado, podemos dizer que, naquele instante, começava a surgir uma espécie de divisor de águas nas práticas literárias, tanto do rio Grande do Norte, quanto de Pernambuco e do Nordeste. Levando em consideração tais situações, cabe aqui a indagar: não teria sido a discussão desse texto um dos motivos do distanciamento entre Gilberto Freyre e Câmara Cascudo? Ou a crítica do potiguar já não seria uma constatação de que, intelectualmente, os dois escritores se encontravam bastante distanciados? (...) (FERREIRA, 2008, p. 88-89).

Sales Neto (2008), ao analisar o artigo "A bengala de Gilberto Freyre”, não concordou com a análise de Ferreira (2008) ${ }^{136}$, e propôs que o artigo não pode ser lido como uma crítica a Gilberto Freyre, ou como uma tomada de posição contrária ao regionalismo. Para o autor, se pensássemos, conforme sugeriu Cascudo, que a bengala era "comum e apta a qualquer Darlington provinciano", teríamos a noção de que a bengala seria algo ordinário e útil a qualquer indivíduo provinciano, ou seja, seria prática às pessoas afeitas ao regionalismo e, por isso, "de certo, [sumiria] sem o rumor de uma revolta”. De acordo com Sales Neto, revolução não era a tônica do Movimento Regionalista-Tradicionalista, seu ideal era a reação, de modo que, no entender de Cascudo, esse movimento sumiria sem ter revolucionado, ou seja, alcançaria seu objetivo: evitar rupturas na sociedade e no saber. Esse trecho teria sido apenas uma crítica sutil ao caráter não renovador que Cascudo percebia no regionalismo, mas, de modo algum, uma demonstração de inadequação com o regionalismo, nem uma tomada de posição em favor do Movimento Modernista e seus desdobramentos de mudança. Para o autor, em sua totalidade, o texto exaltava Gilberto Freyre e, paralelamente, o regionalismo (SALES NETO, 2008, p. 117-119).

Durval Muniz Albuquerque Jr. (2013a) corrobora com o argumento de Sales Neto, afirmando que a militância regionalista de Freyre não parece ter sido em vão, ela deu frutos importantes e permanentes, como a própria ideia de Nordeste, e ajudou a definir o que hoje pensamos ser a cultura nordestina. Estes eventos de 1924 também

\footnotetext{
${ }^{136}$ Vale salientar que o argumento foi redigido a partir da leitura de Sales Neto (2008) sobre a dissertação de mestrado de José Luiz Ferreira (2001), intitulada Modernismo e Tradição: leitura da produção critica de Câmara Cascudo nos anos 20 (Cf. FERREIRA, 2001, p. 58-59). Como a tese de Ferreira (2008) reproduz os argumentos anteriores, optamos por manter a última referência realizada.
} 
podem ser avaliados no que tange à obra de Cascudo, muito embora ele tenha constantemente silenciado a sua aproximação com Freyre e omitido suas relações com os regionalistas e tradicionalistas, episódios estes que não passaram ao largo do movimento cultural encabeçado pelo sociólogo pernambucano. Para Albuquerque Jr, não podemos acreditar que Cascudo, tendo vivido no Recife entre 1924 e 1928 para cursar a Faculdade de Direito, possa ter desconhecido aquela movimentação cultural; que se dava em torno não só de muitas figuras das mais expressivas da intelectualidade e da política local, como do jornal mais influente e de maior circulação na cidade, $O$ Diário de Pernambuco, do qual Freyre era colaborador. Cascudo conviveu com muitos dos membros do Centro e se propôs a ser seu representante no Rio Grande do Norte, afirmando em carta escrita a Freyre em 1940, o seguinte: “Aqui fica, o velho sócio do 'Centro Nacionalista do Recife' na sede no Odilon Nestor, a quem V. indigestou fazendo-o comer nove beijus secos. Abraço. Luís da Câmara Cascudo." (ALBUQUERQUE JR, 2013a, p. 95-96) ${ }^{137}$.

Além destas questões em torno do debate sobre a relação de Cascudo com o regionalismo, vemos o autor potiguar, em carta de trinta de setembro de 1940, solicitar a Gilberto Freyre que intercedesse junto a Rodrigo M. F. de Andrade sobre possíveis ações do SPHAN para a conservação do patrimônio histórico do Rio Grande do Norte, especificamente, pela cidade do Natal. Notadamente os escritos cascudeanos, além de buscarem conduzir os rumos da modernidade natalense, delimitaram uma Natal antiga que estava sendo transformada pelo ímpeto modernizador dos gestores locais. Nesse ponto de intercessão entre a nova cidade construída para o futuro e a cidade nostalgia, Cascudo teria estabelecido uma das primeiras relações de interação e pertencimento com esse espaço, posicionando-se como demiurgo de uma cidade moderna e como zeloso guardador do seu passado (SALES NETO, 2009, p. 21):

E, diga-me, o Serviço do patrimônio Histórico não fará coisa alguma nesse Rio Grande do Norte?

\footnotetext{
${ }^{137}$ Pautando-se em mesma documentação, Sales Neto (2008) propôs que as críticas de Mário de Andrade ao Movimento Regionalista-Tradicionalista, indicando um regionalismo que alcançasse a ideia de brasilidade, foram incorporadas por Cascudo a ponto de, mais tarde, ele terminar a carta a Gilberto Freyre, ao modo como fora supracitado. Segundo Sales Neto, nota-se nesta carta que para Cascudo o Centro deixou de ser regionalista para ser nacionalista. O escritor norte-rio-grandense quis mostrar-se como membro de uma associação que não pensava só a região, mas também a nação (SALES NETO, 2008, p. 156-157). Vale lembrar que o tema já apareceu esboçado no primeiro livro publicado por Cascudo - Alma Patrícia.
} 
Mandei para o Rodrigo o que me foi possível, em documentação fotográfica e notas. Agradeceu e silenciou, (...)

Ninguém aparece. E tudo se perdendo. Há tempos foi o altar-mor da Igreja de Serra Negra, trabalhado de madeira, arrebentado e substituído, quase totalmente. A fortaleza dos Reis Magos, que é um encanto, está indo, aos pedaços.

Estaremos fora do 'master plan' do Serviço? Não é possível (CC, 30IX-1943).

O estudo de Mariza Veloso (2000), que, por intermédio de pesquisa de campo sobre a instituição do Patrimônio Histórico e Artístico Nacional, constatou a relação de extrema proximidade que Rodrigo M. F. de Andrade (então diretor do SPHAN) e Gilberto Freyre mantiveram ao longo de 30 anos. A mesma autora, em pesquisa sobre a obra de Gilberto Freyre, encontrou outra informação que evidencia a estreita relação entre ambos: na primeira hora de criação do SPHAN (instituição responsável pela preservação do patrimônio histórico e artístico nacional), Freyre fora convidado por Rodrigo para ser o representante daquela Secretaria em Pernambuco. A indicação, contudo, não se concretizou. Nos idos tempos do Estado Novo (1937), o interventor de Pernambuco recusou o nome de Gilberto Freyre por não admitir suas posturas políticas, à época, consideradas “comunistas". No entanto, a relação de extrema proximidade entre Gilberto Freyre e o "Patrimônio" (como era chamado) são legítimas e visíveis em inúmeras e concretas situações. Nesse sentido, encontra-se no arquivo pessoal de Rodrigo M. F. de Andrade, hoje sob a guarda da Casa de Rui Barbosa, um rico e significativo conjunto de cartas de Gilberto Freyre a ele endereçadas, onde são discutidas ideias acerca da "origem" da cultura brasileira, e ainda sobre a tradição cultural e a necessidade de sua preservação. Há também registros sobre o sistemático relacionamento de Gilberto Freyre com o grupo do "Patrimônio" - um dos mais atuantes subgrupos do modernismo brasileiro -, em função do fato de a Revista do Patrimônio haver publicado no seu número de estreia (1937), trabalho de Gilberto Freyre intitulado Mocambos do Nordeste: algumas notas sobre o tipo de casa mais primitiva do nordeste brasileiro. Noutra carta, não datada, mas identificada no Acervo da Fundação Gilberto Freyre como de 1940, e certamente posterior à citada anteriormente, Cascudo volta a afirmar "Quando escrever ao Rodrigo catuque sobre o Rio G. do Norte", o que enfatiza o conhecimento de Cascudo sobre a respectiva relação 
e a influência de Freyre sobre Rodrigo M. F. de Andrade (VELOSO, 2000, p. 363-364) 138

Nas cartas enviadas por Gilberto Freyre a Cascudo e preservadas no Ludovicus Instituto Câmara Cascudo, não foi possível encontrar réplica de Freyre sobre o respectivo assunto. Existem na correspondência entre Cascudo e Freyre inúmeras lacunas, impossibilitando a observação de diálogos integrais de muitos dos temas abordados no corpo da respectiva série documental. Fora os documentos já apresentados nesta seção, temos ainda cartas de Câmara Cascudo e Gilberto Freyre enviadas nos anos de 1966 e 1976, que nos dão indícios da aproximação de Cascudo com o regionalismotradicionalista-nordestino.

Em um telegrama postado em vinte e três de setembro de 1966, Gilberto Freyre solicitava que Cascudo viesse participar da reunião que ocorreria em vinte e oito de novembro do mesmo ano, sobre o seminário de tropicologia da Universidade Federal de Pernambuco, quando se confirmaria a participação de Cascudo como conferencista, abordando o tema "culinária doçaria et trópicos":

Solicito ilustre amigo confirmar participação Reunião dia 28 novembro próximo seminário Tropicologia Universidade Federal Pernambuco como conferencista tema culinária doçaria et tropicos (GF, 23-IX-1966).

Em carta escrita por Cascudo no dia vinte e sete de novembro de 1966, o escritor potiguar pede desculpas por não ter respondido antes ao telegrama, porque estava pelo interior do Rio Grande do Norte, realizando pesquisas botânicas sobre timbaúbas e aroeiras. Nesta carta-bilhete, comentou que também demorou a responder por ter esperado a resolução de alguns impasses em torno de uma viagem que realizaria no

\footnotetext{
138 A criação, ainda provisória, em 1936, do primeiro órgão nacional de preservação do patrimônio - o Serviço do Patrimônio Histórico e Artístico Nacional (SPHAN) ocorreu no âmbito do Ministério da Educação e Saúde, cujo titular era Gustavo Capanema. Capanema logo recorreu a Mário de Andrade certamente em função de seu envolvimento no DMC/ SP -, encomendando-lhe a elaboração de um programa de proteção do patrimônio histórico e artístico brasileiro. Mário imediatamente passou a acumular a função de representante do SPHAN em São Paulo; foi nessa condição que elaborou um inventário preliminar, enumerando os exemplares do patrimônio cultural paulista que conseguira identificar em suas excursões com Paulo Duarte. A atuação do SPHAN foi regulamentada pelo Decretolei 25/37 - documento redigido pelo seu primeiro diretor Rodrigo Melo Franco de Andrade - no qual, entretanto, costuma-se apontar a influência do citado anteprojeto de Mário de Andrade. Entretanto, tratase de documentos com ênfases diversas: no de Mário, verifica-se uma preocupação em conceituar o que é patrimônio, inclusive estendendo esta conceituação a expressões da cultura popular; o Decreto-lei 25, por sua vez, privilegia as implicações jurídicas e os efeitos legais do tombamento, principalmente a famosa questão do "direito de propriedade" (PINHEIRO, 2006, p. 8).
} 
mesmo ano para Itália e Bélgica. Como ainda não teria uma definição sobre o assunto, não iria deixar o amigo esperando, apresentando por fim, suas escusas "pela impossibilidade de falar sobre doces e cozinhas em novembro":

Estava no interior, estudando timbaúbas e aroeiras. Daí a demora seu telegrama. Minha situação é a seguinte: - estou me defendendo de uma viagem à Itália e Bélgica temendo o inverno e aguardando resposta as justificativas apresentadas para o adiamento ou renuncia. Desejaria responder quando a resposta chegasse... mas não chegou. Assim, não podendo V. esperar até os primeiros dias de outubro por uma decisão definitiva, apresento minhas escusas pela impossibilidade de falar sobre doces e cozinha no próximo novembro (27-IX-1966).

Para entendermos as razões do convite realizado, é preciso que nos voltemos para o Manifesto Regionalista (1976) e Região e Tradição (1968) de Gilberto Freyre, bem como para História da Alimentação do Brasil (2004) e Sociologia do Açúcar (1971) de Luís da Câmara Cascudo.

No Manifesto Regionalista (1976), é possível se deparar com a passagem a seguir:

uma cozinha em crise significa uma civilização inteira em perigo: o perigo de descaracterizar-se.

As novas gerações de moças já não sabem, entre nós, a não ser entre a gente mais modesta, fazer um doce ou um guisado tradicional e regional. Já não têm gosto nem tempo para ler os velhos livros de receita da família. Quando a verdade é que, depois dos livros de missa, são os livros de receita de doces e de guisados os que devem receber das mulheres leitura mais atenta. O senso de devoção e a obrigação devem completar-se nas mulheres do Brasil, tornando-as boas cristãs e, ao mesmo tempo, boas quituteiras, para assim criarem melhor os filhos e concorrerem para a felicidade nacional. Não há povo feliz quando às mulheres falta a arte culinária. É falta tão grave como a da fé religiosa (FREYRE, 1976, p. 72-73).

A culinária regional seria o quinto elemento dos "Problemas econômicos e Sociais" do Programa Geral do I Congresso Regionalista do Nordeste. Nesta passagem, observar-se que as mulheres, em especial "entre a gente mais modesta", seriam 
responsáveis pela manutenção dos valores regionais, pois “depois dos livros de missa, são os livros de receita de doces e de guisados os que devem receber das mulheres leitura mais atenta". Este aspecto que se fez presente no manifesto de Freyre é compartilhado por Cascudo em seu História da Alimentação no Brasil, publicado inicialmente em 1967. Ao realizarmos estudos sobre a respectiva obra, constatamos que Cascudo comungou com este papel social atribuído às mulheres na região Nordeste e que por causa das transformações impostas pela modernidade, elas abandonavam este saber tido como inato à condição feminina (OLIVEIRA, 2009, p. 83-84):

O ensino da Arte de Cozinha reduz-se à cozinha 'artística' e essencialmente à doçaria. $\mathrm{O}$ trivial básico foi abandonado pela curiosidade das 'fila-famílias' de alta e mediana sociedade. Aprender a cozinhar é dever das moças humildes e pobres, compelidas a papel de auxiliares maternas. A menina que cursa o ginásio liberta-se da penitência compulsória. Está estudando, e não cabe mais na cozinha doméstica. (...) Cem por cento das donas e donzelas eram doceiras e não se atrapalhavam na improvisação de um almoço. Para a maioria presente fazer um café constitui problema, coá-lo certo, negro, perfumado, restaurador. Almoço de lata é comida, e não refeição (CASCUDO, 2004, p. 355).

Quando Cascudo menciona que entre as mulheres de classe média e alta de seu tempo "O ensino da Arte de Cozinha reduz-se à cozinha 'artística' e essencialmente à doçaria”, ele não está condenando o aprendizado da doçaria em si mesmo, mas o fato de que o "Brasil cotidiano está ausente da aprendizagem". "Pratos russos, alemães, ingleses, suecos, [seriam] as "constantes"” (CASCUDO, 2004, p. 355). Caberia sim o aprendizado dos doces portugueses e mouriscos, representados em Sociologia do Açúcar (1971), como a autenticidade da região, do país, “o orgulho da Casa-Grande", como demonstrou Gilberto Freyre em outros estudos ${ }^{139}$ :

\footnotetext{
${ }^{139}$ Em Região e Tradição (1968), podemos ver a fundamentação do argumento apresentado por Câmara Cascudo: "Aos portuguêses é que devemos, principalmente a excelência da mesa brasileira: os sabores por assim dizer fundamentos da cozinha regional mineira, da cozinha regional baiana, da cozinha regional do Nordeste, (...) Foram os portuguêses que nos fizeram herdeiros - numa época em que a sua mesa se aprimorara na 'primeira da Europa' e talvez no mundo - da tradição medieval dos fornos dos mosteiros, (...) herdeiros da tradição como que gótica da cozinha portuguêsa opulenta durante o reinado de Manuel I pelas especiarias asiáticas" (FREYRE, 1968, p. 204).
} 
O orgulho da Casa-Grande brilhava nos doces, Portugal e Mouraria, na competência jurisdicional do Açúcar. Gilberto Freyre recensiou a clássica sobremesa senhorial, salvando o formulário que, às vêzes, era segrêdo, de famílias, insusceptível de vulgarização. (...)

(...)

O Engenho foi a primeira e mais duradoura disciplina dietética. E de ajustamento social.

O processo de nacionalização começa realmente pelo paladar. A cozinha da Casa-Grande ajudou, em percentagem decisiva, (...) (CASCUDO, 1971, p. 178; 181).

Em Região e Tradição (1968), vemos no capítulo "Região, tradição e cozinha" que, ao tratar dos respectivos elementos "dessa expressão de arte colonial”, não saberia o que havia de julgar sobre o paladar afrancesado do escritor Graça Aranha e dos seus “discípulos e aderentes". Pois, em sua opinião, "o temperamento brasileiro se revela mais artisticamente no tempero das comidas patriarcais e de rua que na poesia, em geral destemperada e só de escândalo, dos 'modernistas' e 'universalistas"”:

Dessa expressão de arte colonial não sei o que há de julgar o paladar afrancesado do escritor Graça Aranha e dos seus discípulos e aderentes. Os 'modernistas' do Rio e dos Estados não têm senão desprezo por essas coisas banais do passado brasileiro: arte colonial, cozinha regional, tradição culinária. (...)

Se no fino juízo daquele mestre de 'universalismo' a tradição da arquitetura colonial do Brasil é uma 'melancolia nesta época de cimento armado', melancolia igual para o seu gôsto deve ser a tradição da mesa de nossos avós. Tristonho arcaísmo deve lhe parecer a tapioca ou o munguzá, nestes dias de leite condensado e de doce de lata.

Que me desculpem a caturrice o escritor Graça Aranha, os outros 'modernistas' do Rio e de São Paulo e seus correspondentes nos Estados menores: da minha parte considero a arte de cozinha a mais brasileira de nossas artes. A mais expressiva do nosso caráter e a mais impregnada do nosso passado e das suas constantes. Pode-se dizer que o temperamento brasileiro se revela mais artisticamente no tempero das comidas patriarcais e de rua que na poesia, em geral destemperada e só de escândalo, dos 'modernistas' e 'universalistas'. (...) (FREYRE, 1968, p. 205). 
Em carta de seis de março de 1929, Mário de Andrade, referindo-se à viagem ao Rio Grande do Norte, demonstrou deslumbramento com a culinária potiguar - doces e outros quitutes comidos na casa do anfitrião:

Contei Ariti, bolo de macaxeira, filé à Vila Cascudo, caju de seis meses. Acabei só quando o egoísmo me pediu que não sofresse de saudades tamanhas (MA, 6-III-1929, apud, CASCUDO, 2010a, p. 155).

Lisonjeado pela lembrança dos acepipes, Cascudo, informa em carta de dez de abril de 1929 sobre novas descobertas gastronômicas, enviando inclusive a receita e modo de preparo da "Tapioca Tarsila", iguaria regional, com ares modernistas:

Descobrimos um novo quitute. Batizei-o 'Tapioca Tarsila'. Tem um gosto que lembra o azul e o róseo infantis da senhora do poeta Pau Brasil. Tapioca de goma (caroço grosso) coco ralado e leite do mesmo, açúcar e canela, a forno meio quente e 10 minutos para corar em fogão fechado. Maravilhoso! (...) (CC, 10-IV-1929, Id. Ibidem, p. 157).

Por ter afinidades tão sutis sobre este tema regionalista dos doces e culinária regional, é que podemos dizer que Gilberto Freyre tentou articular o nome de Câmara Cascudo ao regionalismo-tradicionalista-nordestino. É possível perceber este aspecto em dois momentos da obra freyreana. Uma primeira alusão fora feita no prefácio ao Manifesto Regionalista (1976) com o título de "O movimento regionalista, tradicionalista e a seu modo modernista do Recife", Freyre construiu uma imagem ideal do regionalismo e citou inúmeros autores e artistas que representavam a vitória do Movimento Regionalista-Tradicionalista-Nordestino. Em dado momento do texto, o sociólogo pernambucano colocou Câmara Cascudo entre os regionalistas (SALES NETO, 2008, p. 87):

Lembre-se ainda os estudos de história regional de Celso Mariz, além do Amaro Quintas, já recordado, e de Manuel Lubambo. Os de pesquisa etnográfica, folclórica, podendo ser destacados dentre outros, os magistrais trabalhos de Luís da Câmara Cascudo, os de seus discípulos de Natal, (...) (FREYRE, 1976, p. 21). 
Em outro estudo, na sexta edição do livro Nordeste (1989), constam duas referências feitas por Gilberto Freyre ao Câmara Cascudo regionalista presentes no "Prefácio a terceira edição em língua portuguesa" (texto escrito originalmente em 1961). O intuito foi o mesmo: a tentativa de criar um panteão regionalista com diversos pensadores e artistas da região. Assim se referiu Gilberto Freyre na primeira menção: "é esse estilo - um estilo regional susceptível e até sôfrego de transregionalizar-se - que caracteriza (...) o folclorismo de um Luís da Câmara Cascudo - autor de recentes e bons estudos sobre a rede e a jangada do Nordeste" (...) ${ }^{140}$. Mais à frente, nas notas do segundo capítulo em que tratou da relação entre a "cana e água", Freyre reiterou seu ponto de vista: "Com a mesma orientação [dedicada a assuntos regionais] vêm aparecendo nos últimos anos várias revistas, inclusive Região (Recife), (...) e em Natal, Bando, inspirada nas tendências regionalistas do historiador e folclorista Luís da Câmara Cascudo" ${ }^{141}$ (FREYRE, 1989, p. 34, 68; SALES NETO, 2008, p. 88).

A última associação de Câmara Cascudo ao regionalismo tradicionalista realizada por Gilberto Freyre ocorreu em carta enviada ao escritor potiguar no dia trinta de abril de 1976. Na condição de presidente e fundador do Centro de Estudos do Nordeste, Freyre dirigiu-se a Cascudo em tom formal registrando que o mesmo havia sido escolhido como sócio honorário do centro pelos relevantes serviços prestados pela causa do desenvolvimento do Nordeste. Esperava poder contar com a participação de Cascudo na solenidade, que teria ocorrido no Teatro Santa Isabel em vinte e cinco de maio daquele ano:

Tenho a honra de e a grata satisfação de comunicar-lhe que os
fundadores do CENTRO DE ESTUDOS DO NORDESTE, por
unanimidade, em sua reunião de fundação, realizada no dia 22 do
corrente, o escolheram como Sócio Honorário, juntamente com outras

\footnotetext{
${ }^{140}$ Em carta escrita em vinte e nove de setembro de 1957 , vemos Cascudo comentar sobre o envio de Jangada a Gilberto Freyre, como do projeto editorial de Rede de Dormir, onde consta uma pequena antologia de textos sobre a rede na cultura brasileira, fazendo-se presente breve passagem de Casa Grande \& Senzala que faz alusão à temática: "Espero que esteja em sua mão JANGADA que deixei em casa do Anteogenes Chaves e, voltando de Portugal, soube por telefone que V. almoçara lá e naturalmente a JANGADA boiou para Apipucos. Diga-me o que lhe parece porque estou dentro deste horizonte de pesquisas e conclusões. $O R E D E D E D O R M I R$ está quase pronto e nele sua página em $C$. $G$. \& $S$. sobre a rede onipotente para senhor de engenho. E também um informação preciosa de uma pastoral de Bispo de Olinda proibindo que as velhas damas entrassem d'igreja à dentro deitadas nas suas redes. Só conhecia eu, na espécie, os versos de Gregório de Mattos, citando uma entrada de serpentina numa capela baiana" (CC, 29-IX-1957).

${ }_{141}$ As considerações foram feitas precisamente na nota 10 do capítulo. A revista Bando, citada por Gilberto Freyre, circulou em Natal entre 1949 e 1959, contando com a colaboração assídua de Câmara Cascudo (Cf. SALES NETO, 2008, p. 88, n. 112).
} 
quinze personalidades de toda a Região que se distinguiram na defesa do Nordeste.

Esta decisão, conforme justificativa apresentada, se deve aos relevantes serviços que V. Sa. Prestou à causa do desenvolvimento do Nordeste em reiterados e importantes ocasiões, com reflexos muito positivos à integração desta Região e à economia Nacional.

Nesta oportunidade, gostaria de expressar o desejo de contar com sua participação no CENTRO, dando seu apoio, orientação e sugestões, visando a consecução dos elevados objetivos desta entidade.

Esperamos contar com a sua presença na reunião de posse da Diretoria eleita, a realizar-se no Teatro Santa Isabel, às 20 horas, no dia 25 de maio, ocasião em que será prestada uma homenagem a V. Sa. e aos demais Sócios Honorários (GF, 30-IV-1976).

Na pesquisa que realizamos não encontramos na correspondência, nem em notas da imprensa norte-rio-grandense e pernambucana, a alusão ao aceite da convocatória realizada por Gilberto Freyre. O importante dessa comunicação ocorre por contribuir para comprovação da aproximação de Cascudo com Freyre e suas iniciativas intelectuais em torno da região Nordeste. Neste projeto, Cascudo teve considerada relevância por aspectos em sua obra que corroboraram para fundamentação do movimento regionalista-tradicionalista-regionalista, não na condição de discípulo, mas como intelectual atuante na defesa dos temas e assuntos regionais.

\subsection{A correspondência de Câmara Cascudo e José Américo de Almeida (1922-1978)}

Veríssimo de Melo (1993a), relatando uma visita feita ao escritor José Américo de Almeida em seu solar de Tambáu (João Pessoa, PB), indagou ao mesmo sobre uma possível correspondência com Cascudo e qual seria a sua impressão. José Américo informou a Veríssimo que a troca de missivas com Cascudo iniciou-se desde 1922, ano em que se conheceram pessoalmente, até meados de 1978 (MELO, 1993a, p. 6).

Em pesquisa realizada no Ludovicus - Instituto Câmara Cascudo e na Fundação Casa de José Américo de Almeida, pudemos comprovar aquela informação. Sendo que das cartas das décadas de 1920, existem apenas as que foram enviadas de José Américo de Almeida para Luís da Câmara Cascudo espaçadas entre os anos de 1922 (uma carta), 1924 (duas cartas) e 1929-1930 (duas cartas não datadas, sendo contextualizadas quanto ao tipo do papel utilizado, como pelo assunto discutido); os demais registros dos 
respectivos interlocutores se distribuem do seguinte modo: de Cascudo temos cartas enviadas para José Américo em intervalos que vão entre os anos de 1952 (uma carta), 1966 (duas cartas), 1975-1976 (duas cartas, uma para cada ano respectivamente), e uma que não está datada mas devido ao conteúdo, deve ter sido escrita entre 1966 e 1976. De José Américo para Cascudo, ainda teremos cartas em 1966 (uma carta), 1972-1973 (duas cartas uma para cada ano respectivamente); 1977-1978 (três cartas, uma no início do intervalo e duas ao final) ${ }^{142}$.

Na carta não datada, Cascudo dirá em breve passagem que conhecera José Américo de Almeida em maio de 1922, no V Congresso Brasileiro de Geografia, na Paraíba ${ }^{143}$. Infelizmente, não temos registros epistolográficos de Câmara Cascudo que traten com maior profundidade sobre esse encontro, mas percebe-se por intermédio das cartas que José Américo de Almeida enviou durante a década de 1920 e no decorrer do recorte temporal de nossa pesquisa mensagens que evidenciam uma grande estima do autor da Bagaceira pelo etnógrafo potiguar.

Em carta de sete de maio de 1922, vemos José Américo de Almeida tecer comentários sobre o envio de uma obra de Cascudo para a sua apreciação. Desculpa-se pela demora em responder dizendo crer que o amigo "não ficaria contente, se (...) tivesse enviado apenas o registro do correio", que precisava recolher primeiro "a impressão do seu talento, com uma leitura a vontade, para ao cabo mandar dizer-lhe o que tinha recebido". Embora não deixe explícito qual livro teria sido, pelo modo como se referiu, e pelo ano da carta, devia se tratar do primeiro livro de Câmara Cascudo, Alma Patrícia escrito em 1920:

Acabo de ler sua carta. Não seja (mais) para os estafetas! ... Seu livro logrou-me as mãos com toda a regularidade pontual. Mas v. não ficaria contente, se eu lhe tivesse enviado apenas o recibo do correio. Era preciso que eu recolhesse, primeiro, a impressão do seu talento,

\footnotetext{
${ }^{142}$ Embora seja uma documentação inédita, só nos ateremos nesta seção às cartas que tratam dos temas referidos a nosso objeto de estudo.

${ }^{143} \mathrm{Na}$ Fundação Joaquim Nabuco, é possível encontrar uma carta de Cascudo enviada a Mário Sette, em dez de maio de 1922, onde, vemos o escritor potiguar informar sobre o evento: "Sigo esta semana para a Parahyba representando o Centro Polymático no VII Congresso de Geographia. Ironias da sorte zombeteira. Se me perguntarem os limites do Rio Grande do Norte fui de pestanejar atturdido, sem resposta razoavel. Mas... estava escripto que acabaria geographo. Deus me defenderá de um relatório ou demais (sic.) remoídos durante as sessões de (sic.)" (CC, 10-V-1922). Desse modo, percebe-se que o evento mencionado já se encontrava na sétima versão e não na quinta. Outro aspecto curioso é que a primeira carta de José Américo localizada no Ludovicus - Instituto Câmara Cascudo é de sete de maio de 1922, e pela abertura da carta é possível entender que eles já se conheciam antes do evento, ao menos por intermédio de troca de correspondências.
} 
com uma leitura a vontade, para ao cabo mandar dizer-lhe o que tinha recebido.

V. revela uma compreensão definida de arte, recursos de estilo e vivacidade de imagens. As cadências e a abundância verbal vão por volta dos tipos da mocidade.

Com uma disciplina mas paciente da língua e a descoberta da vaidade de citação, com um pouco mais de sobriedade, enfim, v. será, se já não amanhecer, ecos ainda de um escritor, de verdade, digno de toda a consideração desse título.

Agita seus feridos esse sofrer de mocidade que extrema símbolos literários do pioneiro dos lugares comuns.

A critica impressionista talvez seja mais oriunda da solidariedade local do que de um rigoroso processo de selecção.

Mas v. comprova, às vezes, seus (galbos) como uns modelos que o homem (e) as letras de sua terra com preciosos subsídios para o nosso acervo intelectual (JAA, 7-V-1922).

Podemos perceber que apesar dos elogios estabelecidos ao jovem escritor, temos nesta carta uma crítica severa que deve ser tomada como estímulo de aprimoramento de estilo e produção intelectual. O livro de estreia de Cascudo, intitulado Alma Patrícia, foi dedicado exclusivamente a autores norte-rio-grandenses, com predomínio de poetas e destaque secundário para jornalistas, registrando uns poucos dramaturgos, sem maior entusiasmo. De acordo com Marcos Silva (2013), o título dessa obra, diante de seu conteúdo, permite pensar sobre o projeto de definir um "nós" - os potiguares, os patrícios -, dotados de uma alma, através de sua leitura. Ao mesmo tempo, o adjetivo "patrícia" também evoca condição aristocrática, algo que se destaca do comum: nós, potiguares, já temos uma alma, e essa alma não se nivela por baixo; a literatura erudita do Rio Grande do Norte, mesmo que falha nobilitava o estado (SILVA, 2013, p. 221222).

Em carta de trinta de maio de 1924, temos outra carta onde José Américo, volta a iniciar se justificando pela não assiduidade em escrever ao jovem amigo potiguar, pois o mesmo não saía de sua lembrança, tão pouco de seu apreço intelectual. Por isso, escrevia imediatamente em resposta à carta em que Cascudo reclamava o seu "aclamado 
livro", que por se tratar da época em que foi escrita, deveria se tratar de A Paraíba e seus Problemas ${ }^{144}$ publicado em 1923:

Não, Luiz da Câmara Cascudo, v. não saiu da minha lembrança, nem do meu apreço intellectual. Por isso, quando me chegou sua carta, reclamando o meu aclamado livro, eu já havia coincidentemente, cumprido, havia dois dias, esse dever de solidariedade literária.

(...)

Leia-me v., se não com generosidade, pelo menos com a paciência devida (JAA, 30-V-1924).

Na última carta de José Américo enviada a Cascudo no ano de 1924, vemos o escritor paraibano estabelecer uma crítica bastante positiva ao livro Histórias que o tempo leva..., do jovem escritor potiguar, apontando que a obra, por sua forma quase literária, auxiliava os "admiradores da leitura amena, continu[asse] a sua funcção educativa e moral":

Somente hoje achei de ler seu livro. Muito obrigado. V. proporcionoume algumas horas de grande recreação espiritual.

Essas histórias o tempo não levou porque v. as arrebatou do passado, atribuindo-lhes o fremido de vida e de suavidade de quem sabe contar. Aprecio muitíssimo o querer que v. objetou. Nesta quadra de versos à cultura, de sua capacidade para as amplitudes do estado e do pensamento, é preciso contar a história, reverter os fatos, dar forma, dar ficção, para que essa disciplina, acceita, assim pelos admiradores da leitura amena, continue a sua funcção educativa e moral.

Seu livro ele não é para se guardar depois de voltada a ultima página. Voltarei nestes poucos dias a seu começo para uma impressão mais duradoura (JAA, 16-VII-1924).

\footnotetext{
${ }^{144}$ Em A Paraíba e seus problemas (1984), José Américo de Almeida discute todos os pontos que, segundo ele, conduziram aquele estado e o Nordeste a uma situação econômica e política desfavorável no cenário nacional. Situação esta decorrente da omissão injustificável da classe dirigente, isto é, da classe política, que se pautou, na mais pura inércia, ou mais gravemente em uma "despudorada renúncia". Em sua análise, ele traz a lume a indicação daquilo que acreditava ser a solução para estes mesmos problemas. Os principais pontos problemáticos da Paraíba e da região eram os seguintes: Em primeiro lugar, timidez e ineficiência política dos homens públicos paraibanos e nordestinos, que teve como consequência o não aparelhamento desses Estados - a exceção, em parte, Pernambuco e Bahia - em rodovias, ferrovias, comunicações, portos, etc. Evidenciando-se, no caso paraibano, para a evasão de impostos. Em segundo, a ausência de educação técnica para melhor aproveitamento na agricultura e pecuária. Por fim, a falta de investimentos na produção agrícola, o que levava os agricultores ao endividamento, em virtude da agiotagem (ASSIS, 2005, p. 37).
} 
Percebe-se através da apresentação dessas últimas cartas enviadas por José Américo de Almeida a Câmara Cascudo, ocorrer aquela condição já trabalhada no capítulo três desta tese, por intermédio de Machado (2012), ou seja, houve entre os respectivos interlocutores o uso da correspondência para compartilhar manuscritos no intuito de divulgação e solicitação de crítica à produção intelectual que estavam desenvolvendo à época.

Nas últimas duas cartas da década de 1920, vemos José Américo tratar de assuntos que não são de ordem intelectual, mas ao final da segunda carta, encontramos um trecho que chamou nossa atenção. José Américo comenta com Cascudo a respeito de Mário de Andrade, dando a entender que trocava correspondências com o mesmo. Solicitou ao amigo potiguar que trouxesse Mário ao Nordeste e a Parahyba do Norte ${ }^{145}$ :

\footnotetext{
Por que não vem até aqui com o Mário?

Elle tem escripto de S. Paulo. Está muito saudoso do nordeste.

O Mario é bom como quê! (JAA, s./d.).
}

Com a respectiva menção a Mário nas cartas de José Américo enviadas a Cascudo, tratamos de buscar nos acervos das instituições pesquisadas alguma referência que comprovasse a existência da troca de correspondências entre José Américo e Mário de Andrade.

Inicialmente, verificamos que no catálogo virtual do IEB/ USP, não constam cartas enviadas por José Américo a Mário.

Através do levantamento feito nas obras de Mário de Andrade, encontramos em o Turista Aprendiz (1983) e Taxi e Crônicas no Diário Nacional (1976) referências sobre a aproximação de Mário e José Américo. Em o Turista Aprendiz, temos que o encontro ocorreu entre os dias vinte e oito de janeiro e cinco de fevereiro de 1929. Nessa narrativa, vemos Mário tratar da sua recepção na cidade da Paraíba do Norte por José Américo e a intelectualidade local, como da impressão que teve do autor da Bagaceira:

Cheguei contente na Paraíba com os amigos, José Américo de Almeida, Ademar Vidal, Silvino Olavo me abraçando. (...)

(...)

\footnotetext{
${ }^{145}$ Atual João Pessoa, capital do estado da Paraíba.
} 
E Paraíba além de outras coisas tem José Américo de Almeida, autor da Bagaceira, todos no Brasil sabem. Aliás José Américo de Almeida nasceu no "brejo" em Areia para onde vou amanhã. Mas José Américo mora na capital, jurisconsulto, conhecedor profundo do nordeste, míope dos olhos apenas, secretário geral do Estado, modesto e justamente célebre (ANDRADE, 1983, p. 307; 316).

Já em Táxi e Crônicas no Diário Nacional, encontramos uma crônica de Mário sobre José Américo de Almeida escrita em dezesseis de novembro de 1930. Neste texto, Mário, ao noticiar a nomeação de José Américo como ministro da viação, comentou que "o célebre autor e justamente célebre, da Bagaceira, agora se viu transformado inteiramente (...) de homem público das Letras, para homem público do Brasil”, em dado momento Mário reclamou da ausência de resposta das cartas que enviou ao amigo; afirmou que compreendia o fato, sabia que o amigo sofria mais que ele próprio, pois tinha os inúmeros afazeres da vida política:

\begin{abstract}
Aliás fazia muitos meses que José Américo de Almeida estava afastado já de mim. Desque arrebentou o caso de Princesa ${ }^{146}$. Vivi Princesa com uma intimidade dolorosíssima. Isso era natural em quem como eu viajara o Nordeste e faz dois anos colhe todos os seus momentos livres pra edificação dum livro sobre Aquele Brasil puro. (...) Me limitei por isso a cultivar o meu pombal de cartas amantes, buscando os amigos paraibanos que sofriam. De minha casa sei que as pombas partiram. Se chegaram aos destinatários não sei. Falava-se que havia censura no Correio de lá.

José Américo de Almeida nunca que respondeu. Mas não zanguei porque ele inda sofria mais do que eu. (...) (ANDRADE, 1976, p. 275).
\end{abstract}

\footnotetext{
${ }^{146}$ No que tange ao conflito em Princesa Isabel, PB, as considerações de José Américo sobre os problemas da resistência são extremamente significativas e pertinentes, haja vista centrar a questão no Comando e não na tropa, ou seja, o que ocorria na tropa era o reflexo das desinteligências ocorridas na condução da luta, bem como o bloqueio imposto ao estado. Para Américo, "só a visão direta evitaria o colapso. Andava nessa causa aos trancos e barrancos, estava por assim dizer, nas últimas e nada se sabia de positivo...", e o que ele acreditava ser necessário fazer era "... representar a autoridade única, corrigindo os distúrbios causados pela rivalidade entre comandos..."; assim, precisava estar no local do conflito. As notícias que chegavam à cidade da Paraíba eram que havia "... uma cinta em torno (de Princesa), a contê-la", o que não era verdade, porquanto das informações de invasão de outras áreas do Cariri e Sertão, até pouco tempo, infensas às desordens. Assim, Américo percebia em seu deslocamento para o sertão, que "... alastrava-se o conflito. As coisas não estavam boas; o inimigo vinha vindo". (ALMEIDA, 1978, p. 72-76; ASSIS, 2005, p. 95).
} 
Ao constatarmos por intermédio dessa crônica que Mário havia enviado cartas a José Américo de Almeida, fomos à busca de algum elemento que fundamentasse as evidências disso. Em dado momento da pesquisa, nós nos deparamos com o Catálogo da Correspondência de José Américo de Almeida (cartas: 1915-1952), de Ana Isabel de Souza Leão Andrade (1983), por intermédio deste catálogo, pudemos constatar nossa hipótese: nele, estão registradas duas cartas de Mário. Uma delas, de vinte e sete de dezembro de 1929, escrita logo após o seu retorno a São Paulo, que tratou do projeto de criação do livro Na Pancada do Ganzá ${ }^{147}$, e a outra, de vinte e sete de julho de 1930 ${ }^{148}$, em que se apresentam os reclames postos por intermédio da crônica supracitada:

Jurei pra mim não incomodar você porém não venço a saudade, banco o amante sem brio e mando estas linhas. Si não tiver tempo não responda não faz mal, não zango não. Mas você deve se interessar pelo que eu truxe aí do Nordeste e aqui vai notícia detalhada pra você mostrar também pro Ademar, pra evitar repetição. O livro se chamará 'Na Pancada do Ganzá', terá Prefácio, três partes (I A Poesia; II A Música; III Documentação). Índice analítico, bibliografia, etc. No Prefácio faço uma relação sucinta da minha viagem e exponho os fins do livro talvez minha maneira de conceber o Folclore. Isso não sei se ponho porquê faço questão de não ser folclorista, ou pelo menos não bancar o folclorista, que não tenho especialização para tanto. Em todo caso demonstrarei ou indicarei certas doutrinas bem recentes de conceber o folclore, aceitando a criação individualista. Isso é importante porquê o individualismo do individuo popular nordestino é mesmo desnorteante nas peças livres como os loucos. Um documento chega a mudar inteiramente de apresentação dum lugar para outro. Nas outras partes os títulos já indicam a natureza dos estudos que vêm nelas. Separo a documentação da exposição crítica da poesia e da música, pra metodisar mais a leitura e porquê os documentos estão ou estarão recheados de notas, indicação de variantes, descrição de bailes

\footnotetext{
${ }^{147} \mathrm{Na}$ Pancada do Ganzá consistia num projeto (obra em preparo) em que Mário de Andrade pretendia reunir o amplo material poético-musical-coreográfico recolhido em suas viagens etnográficas, apoiandose nos estudos e coletâneas existentes. Esse cancioneiro deveria se escorar de segurança teórica e terminológica, daí a confecção simultânea de outra obra de fôlego, o Dicionário Musical Brasileiro, iniciada no mesmo ano de 1929. Para estas obras, o autor indicaria um processo de trabalho na relação das "Leituras iniciadas prá Na pancada do Ganzá", cujo registro em seu arquivo no Instituto de Estudos Brasileiros/USP consigna uma bibliografia de 837 obras. É no âmbito da "atitude interessada", das reflexões e da postura obsessiva de Mário de Andrade de levar a termo esse projeto de preservação da "autenticidade" da cultura brasileira, que ele projeta, planeja, esboça, organiza suas recolhas e estudos, e inicia as escrituras de sua obra "grandiosa". A vida, no entanto, não lhe reservaria tempo para concluí-la (LOPES \& GOMES, 2014, p. 166).

${ }^{148}$ Os respectivos documentos pertencem ao acervo da Fundação Casa de José Américo de Almeida.
} 
etc. etc. E tudo junto ficaria a leitura penosa. E como na exposição crítica virão as referencias sistematizadas aos números da documentação que provam a afirmativa quem quizer pode imediatamente se reportar à documentação. Não escrevi nenhuma linha do livro ainda e provavelmente tão cedo não escreverei. Estou sempre passando a limpo o que trouxe daí, estudando a colheita e estudando a matéria nos livros. O que já tenho de notas, esclarecimento, citações é formidável, perto de mil papeletas, é interessantíssimo. Desconfio muito que a bibliografia, que conterá só obras citadas no texto apresentará pra mais de 200 numeros! Si não tiver mais, pois que tenho 50 obras referidas ao livro. Uma coisa me entristece um bocado. Sou o primeiro a registrar integralmente, texto e musica, todas as danças dramáticas nordestinas. Bumba, Bonzo, Chegança, Fandango, Caboclinho, maracatú. Não registrei nenhum pastoril, por serem estas musicalmente menos interessantes. Agora estou burramente arrependido. Fica uma falha feia no livro. É uma pena. Quanto à demora peço mais dois anos. Em fins de 1931, o livro estará pronto. Mas também garanto que vocês não se arrependerão da amizade inesquecível que me deram. Quando penso nela fico mesmo comovido. E o abraço que vai aqui pra você é sinceramente o mais fraterno. E me recomende carinhosamente aos seus. (MA, 27-XII1929) ${ }^{149}$

Estou exausto de escrever pra você, pro Ademar, sem receber resposta. Será que enfim você recebe esta? Nem carta escrevo mais, quasi na certeza de você não receber. Quantas já partiram e que certamente teriam uma palavrinha de bom dia como volta, si aí chegassem!...

Faço muita papelada e mais uma vez, sem dizer nada, só comovido, comovidíssimo, mando este abraço verdadeiro de quem vive com o pensamento em vocês.

Si estiver com o Ademar abrace-o tambem por mim. E fico aqui, machucado, estragado por dentro, nesta sensação dolorosíssima de que vocês, não recebendo nada de mim, possam imaginar um ingrato que esqueceu a amizade de vocês. Isso é impossível em mim (...) (MA, 27VII-1930).

\footnotetext{
${ }^{149}$ Vale salientar que tais aspectos foram também tratados, em carta de Mário de Andrade enviada a
} Câmara Cascudo (Cf. MA, 6-VIII-1929, apud, CASCUDO, 2010a, p. 163). 
Se voltarmos à passagem em que José Américo comenta com Cascudo a saudade que ele sentia de Mário do Nordeste, subentende-se que o escritor paraibano tinha conhecimento das cartas que o escritor de Macunaíma lhe enviou. Pelo comentário apresentado nas duas cartas, vemos que estas não foram às únicas tentativas de Mário de estabelecer diálogo epistolar com o autor da Bagaceira. Sendo as únicas existentes e preservadas, percebe-se que o contato estabelecido com José Américo e seu grupo intelectual paraibano foi bastante relevante para a coleta etnográfica realizada pelo escritor paulista ${ }^{150}$. Com o retorno para São Paulo, como vemos na transcrição da carta de 1929, iniciou-se a tentativa de interpretação e elaboração de um árduo trabalho de sistematização dos dados e fontes bibliográficas, mas que infelizmente não chegou à conclusão. O Departamento de Cultura da cidade de São Paulo e outros projetos foram cada vez mais tomando o seu tempo, ficando a cargo de Oneyda Alvarenga, sua amiga e colaboradora, a editoração e publicação dos inéditos postumamente.

Este aspecto inusitado presente no corpo da correspondência de Cascudo e José Américo demonstra o quão importante foi para Mário estabelecer contato com Cascudo. Neste ponto, notamos mais uma vez, que ao contrário do que se divulgou nas teses de Veríssimo de Melo e dos demais estudiosos que seguiram a linha de argumentação até o presente momento sobre a relação entre Mário de Andrade e Câmara Cascudo, idealizada como o mestre modernista e o discípulo folclorista, ela não se sustenta. Além de comprovar o caráter eclético dos interlocutores, que se valiam das cartas para estabelecer redes de sociabilidade que promovessem o debate intelectual, sem a necessidade de enquadramento em estéticas e cartas programas de manifestos artísticos culturais... Veríssimo muito se esforçou na busca de confirmação da correspondência entre Cascudo e Mário, como entre Cascudo e José Américo, em momentos distintos; tendo em vista seu franco interesse por correspondências entre intelectuais ${ }^{151}$, é no

\footnotetext{
${ }^{150}$ Fora os argumentos presente na carta de vinte e sete de dezembro de 1929, podemos ver, por exemplo, a passagem presente no Turista Aprendiz (1983): (...) "Logo de entrada [na praia de Tambaú], pra me indicar a possibilidade de bom trabalho musical por aqui, topei com os sons dum coco. O que é, o que não é: era uma crilada gasosa dançando e cantando na praia. Gente predestinada pra dançar e cantar, isso não tem dúvida. Sem método, sem ritos coreográficos do coco, o pessoalzinho dançava dos 5 anos aos 13, no mais! Um velhote movia o torneio batendo no bumbo e tirando a solfa. Mas o ganzá era batido por um piazote que não teria 6 anos, coisa admirável. Que precocidade rítmica, puxa! O piá cansou, pediu pra uma pequena fazer a parte dele. Essa teria 8 anos certos mas era uma virtuose no ganzá. Palavra que inda não vi, mesmo nas nossas habilíssimas orquestrinhas maxixeiras do Rio, quem excedesse a paraibaninha na firmeza, flexibilidade e variedade de mover o ganzá. Custei sair dali." (ANDRADE, 1983, p. 308).

${ }^{151}$ Além da publicação das Cartas de Mário de Andrade a Luís da Câmara Cascudo e de seus artigos que tem esta correspondência como mote, Veríssimo de Melo ainda publicou mais dois livros com a correspondência de outros interlocutores: Ascenso Ferreira e Oswald Lamartine de Faria (Cf. MELO, 1989b, 1995).
} 
mínimo intrigante pensar por quais razões Veríssimo não questionou Almeida sobre o recebimento de cartas de Mário de Andrade?

Após estes aspectos discutidos por intermédio das cartas que José Américo enviou para Câmara Cascudo no decorrer da década de 1920, nós nos voltaremos para a primeira carta enviada por Cascudo presente no acervo da Fundação Casa de José Américo de Almeida. A mensagem foi escrita em quatorze de julho de 1952 e nela, vemos Cascudo se dirigir ao velho amigo de outrora como o governador do Estado da Paraíba ${ }^{152}$, e comentar sobre um plano seu, que gostaria de articular com os "amigos queridos que são atuais Governadores em Alagoas, Pernambuco, Paraíba e Rio Grande do Norte": convidar o editor José Olympio 153 "para ele visitar cada um desses Estados, três ou quatro dias apenas, conhecer o que não conhece e ama ter um contacto mais vivo com o ambiente provinciano". Entretanto, Cascudo não queria ser colocado como idealizador dessa iniciativa, mas que o convite fosse feito por José Américo, o escritor que teve seu celebre livro A Bagaceira, publicado pelo editor e que na ocasião, na condição de governador e grande articulador político do Nordeste; sendo esta "uma ocasião única para ele [José Olympio] ver o que é nordeste e os problemas enfrentados pelos governadores, desajudados ou pouco ajudados":

Queria merecer-lhe o obséquio de ouvir e responder a esta sugestão que faço com todos os segredos de justiça e mistérios do Santo Ofício. Não desejo de modo algum aparecer no meio porque o valor será justamente o ato pessoal do grande José Américo ${ }^{154}$. Lembrei de pedir aos amigos queridos que são atuais Governadores em Alagoas, Pernambuco, Paraíba e Rio Grande do Norte, que fizessem um convite ao editor José Olympio para ele visitar cada um desses Estados, três ou quatro dias apenas, conhecer o que não conhece e ama e ter um contacto mais vivo com o ambiente provinciano. Não se trata de

\footnotetext{
${ }^{152}$ Para o aprofundamento deste aspecto da biografia política de José Américo de Almeida, ver os estudos de Assis (2005) e Barbosa (2012).

153 Na correspondência estabelecida entre Câmara Cascudo e Gilberto Freyre, também veremos o primeiro fazer referência ao editor José Olympio, só que em outro contexto. Em carta enviada a Freyre no dia dez de março de 1953, o escritor potiguar, pede para que o amigo intermediasse um projeto editorial que não fica explicito, tendo em vista que se refere ao mesmo como "brinquedo": "Desejava que V. ratificasse o convênio de Apipucos em que prometemos auxílio mútuo na fabricação de um 'Brinquedo' e seu aviso ao José Olympio, garantido o lugar na fila" (CC, 10-III-1953). Vale ressaltar que a partir da década de 1950, Cascudo publicará algumas de suas obras pela editora de José Olympio.

${ }^{154}$ Em carta enviada a José Américo em cinco de abril de 1966, Cascudo diz que quando ia a João Pessoa, $\mathrm{PB}$, sempre tinha alegria em revelar a alguns paraibanos a vera-face do "real" José Américo: (...) "escultura de granito, eriçada de cactos, coberta de boninas. Ternura, bondade, jubilo sereno, entendimento imediato para às coisas intraduzíveis. Um encanto, sêu Zé Américo..." (CC, 5-IV-1966).
} 
convite coletivo e sim um convite seu, direto. Depois combinar-se-ia o programa de viagem geral. José Olympio não é o grande editor, é também e acima de tudo, o editor do nordeste, àquele que maior número de originais nordestinos que tem divulgado. Seria uma ocasião única para ele ver o que é nordeste e os problemas enfrentados pelos governadores, desajudados ou pouco ajudados (CC, 14-VII-1952).

A seca enfrentada pelos paraibanos durante o governo de José Américo de Almeida - mais especificamente entre os anos de 1951-52 - se inicia meses antes de sua posse, verificada no dia primeiro de fevereiro de 1951. Os primeiros indícios de uma calamidade iminente foram sentidos em alguns municípios do interior do Estado ainda na segunda metade do ano de 1950. Embora as primeiras notícias referentes a essa problemática tenham surgido ainda no governo do udenista Osvaldo Trigueiro, passando pelo curto período da administração de seu sucessor e vice-governador, José Targino, os problemas relacionados a esse prenúncio de grande estiagem só receberam a atenção merecida a partir dos primeiros meses da gestão americista (BARBOSA, 2012, p. 185).

Nos primeiros meses da administração de José Américo de Almeida, o retrato da paisagem desoladora vivenciada diariamente por uma grande parcela dos habitantes do estado paraibano e da maior parte da região Nordeste - ou que já observaram à distância em alguma fotografia, documentário, filme, ou leram em alguma obra literária ou científica - foi muito bem descrita por José Lins do Rêgo em uma matéria publicada pelo jornal A União durante esse período de estiagem (Id. Ibidem, p. 185):

As histórias de Raquel de Queiroz, de José Américo, de Graciliano Ramos, passam da ficção vigorosa para a realidade pungente. As retiradas se farão com as vias-sacras de um povo que morre aos pedaços. Os lares se desfazem, as pestes se concentram, a terra abandonada se reduz a nada. Sol e fome, sol e doença, sol e morte de todos os tamanhos (RÊGO, 1951, p.3).

$\mathrm{O}$ autor da matéria, e os demais escritores anunciados no fragmento, tiveram seus livros editados e distribuídos no mercado editorial brasileiro por José Olympio. Vale salientar que a inauguração da casa editorial de José Olympio ocorreu em junho de 1934, tendo José Lins do Rêgo em noite de autógrafos no lançamento das edições feitas por Olympio na recém-inaugurada sede da editora no Rio de Janeiro. A compensação 
pela ousadia do editor não veio propriamente da venda das edições (que levaram cinco anos para se esgotar), mas sim do fluxo de escritores para a editora "doida o bastante para imprimir dez vezes mais que a tiragem normal de um novo romance brasileiro, e ainda pagar adiantado" (HALLEWELL, 1985, p. 355). Ousadia comercial que despertou o interesse de romancistas, poetas e artistas plásticos de diferentes regiões do país. Devendo-se notar ainda que, progressivamente, o deslocamento dos artistas ditos regionalistas para a capital federal significará, também, uma nacionalização das discussões sobre o Regionalismo-Tradicionalista- Nordestino (CHAGURI, 2009, p. 6465), evidenciando o peso da literatura de ficção no fortalecimento desse universo de pensamento.

Embora não tenhamos comprovação de que a iniciativa tenha ocorrido, a carta que Cascudo enviou para José Américo em 1952 é um bom exemplo de como são enredadas as alianças regionais de várias ordens (políticas, intelectuais e pessoais), demonstrando que a tentativa de Cascudo de convencer José Américo para convidar um dos maiores editores brasileiros para visitar os estados nordestinos não é meramente uma iniciativa de cunho cultural, mas acima de tudo um ato político, pois Cascudo queria com aquele gesto chamar a atenção da política nacional para os problemas que a região Nordeste vinha sofrendo na ocasião. Utilizando-se do "discurso da seca", tido neste contexto por Albuquerque Jr. (2011) como o elemento responsável pela progressiva unificação dos interesses regionais e detonador de práticas políticas e econômicas que envolviam todos os estados sujeitos a este fenômeno climático; vemos que neste discurso Cascudo faz da seca a principal arma para colocar em âmbito nacional os interesses dos políticos dos estados nordestinos, delimitando assim uma zona de solidariedade entre todos aqueles que se colocavam como porta-vozes deste espaço social sofredor (ALBUQUERQUE JR, 2011, p. 72-73).

As duas últimas cartas enviadas por Cascudo a José Américo entre os anos de 1975 e 1976 são breves bilhetes de apresentação. Na primeira, ao apresentar Jorge Batista, refere-se ao mesmo como "um jornalista teimoso do MOVIMENTO, semanário que se apregoa 'nacional'", sendo certamente uma referência feita ao modernismo. Na segunda, comentou que "os nossos verdes e teimosos anos de oiticica não estabelecem distancia com a geração nova, rapazes e moças que irão viver no Ano 2000”, e após este pequeno introito, apresenta Paulo de Assis Cavalcanti, pintor, e escritor de contos, novelas, que buscou inspiração em obras de José Américo, tais como a Bagaceira, 
Coiteros, Boqueirão, colocando-se por fim como "porteiro-apresentador neste Nordeste":

JOSÉ AMÉRICO, amigo jovem de maio de 1922. Tenho a oportunidade de apresentar-lhe Jorge Batista, jornalista teimoso, do MOVIMENTO, semanário que se apregôa 'nacional'. Pelo menos de bom gosto. V. não escapa ao destino publicitário. JORGE BATISTA sonha ouvi-lo e levo este facínora até as doces áreas auditivas de sua confidencia gentil (CC, 12-X-1975).

JOSÉ AMÉRICO ALMEIDA, amigo. Os nossos verdes e teimosos anos de oiticica não estabelecem distancia com a geração nova, rapazes e moças que irão viver no Ano 2000. Visitam. Louvam. Pleiteiam. Permita-me apresentar-lhe o jovem PAULO DE ASSIS CAVALCANTI, morador em Arco Verde, na bôca do Sertão pernambucano. É pintor, de côres vibrantes e desenho firme, documentando a paisagem em que vive, com as figuras humanas na legitimidade do contorno e movimento. Tem livros de contos e novelas, com a mesma autenticidade vibrante e lógica, aquela que se modelou na BAGACEIRA, COITEIROS, BUQUEIRÃO. Já tem merecido algumas distinções e sucessos positivos. Um seu insistente desejo é ouvir, de viva-voz, o nosso JOSÉ AMÉRICO. Cumpro meu destino de porteiro-apresentador neste Nordeste (CC-21-1-1976).

A amizade entre Cascudo e José Américo, perdurará até à morte deste último em 1981. O último ano da série desta correspondência será 1978.

Antes de finalizar o presente capítulo, faz-se necessário realizarmos uma breve incursão sobre os acontecimentos vividos por Câmara Cascudo no ano de 1978. Folheando o jornal A República, vemos que primeiro semestre do ano foi extremamente movimentado para o autor. No dia vinte e cinco de fevereiro, aquele jornal noticia que Cascudo havia ganhado o Prêmio Juca Pato, 1977, mas que não acreditava, mesmo tendo sido a informação noticiada pela TV e pelo jornal impresso:

A notícia já veiculada pela Folha de São Paulo e a TV Globo não bastou para convencer o folclorista e escritor Luiz da Câmara Cascudo de que ele foi o vencedor do prêmio Juca Pato, concedido anualmente a quem mais se destaca em obras literárias. A láurea é uma das mais importantes do país, concedida pela União Brasileira de Escritores. 
Para este ano estavam indicados Barbosa Lima Sobrinho, jamil Almasur Daddad, Gilberto Freyre e Wilson Martins. 'Eu nem sabia que estava nessa relação’ disse o escritor Câmara Cascudo , ao ser consultado ontem pela 'A República'. Disse contudo que 'foi uma grata surpresa, porque não houve inscrição voluntária. Pode ser até um bom trote. Só acredito quando receber o prêmio e uma comunicação da União Brasileira de Escritores'. (...) (s./a. “Cascudo não acredita no prêmio - TV e Jornal dizem que Câmara Cascudo ganhou o Juca Pato”. In. A República, 25-II-1978).

Em cinco de março, numa matéria de foto estampada, vê-se em letras garrafais: "CÂMARA CASCUDO É DOUTOR HONORIS CAUSA DA UFRN". Segundo a matéria, a concessão deste título já teria sido comunicada a Cascudo pelo Reitor Domingos Gomes de Lima que, em reunião com o colegiado superior da instituição, propôs o nome e foi aceito por unanimidade. Embora só neste momento tenha sido anunciada, a notícia já era do conhecimento do escritor e folclorista potiguar desde as comemorações de seu aniversário em trinta de dezembro de 1977. Entretanto, a entrega do título só seria feita em solenidade a ser marcada para o semestre de 1978 (s./a. A República, 05-III-1978).

Poucos dias depois, em doze de março, nova matéria que tratando da consagração de Câmara Cascudo, desta vez, seria o fato do folclorista ter sido escolhido como o intelectual do ano pela União Brasileira de Escritores, seção São Paulo, responsável pela escolha e premiação. Segundo informe da matéria, Cascudo teria recebido cento e quarenta e quatro votos e o informante da láurea teria sido o escritor Raimundo de Menezes, num telefonema recebido neste dia por D. Dhália Cascudo:

O escritor e folclorista Luiz da Câmara Cascudo foi escolhido pela União Brasileira de escritores, secção de São Paulo, como o 'intelectual do ano', seguindo comunicação do presidente daquela entidade, feita através de telefone para a residência do escritor potiguar. Quem recebeu a comunicação foi a esposa D. Dhalia, tendo o Sr. Raimundo de Menezes, escritor paulista, dito na ocasião que a decisão tinha sido tomada por 144 votos. (...) Antes mesmo da votação já se tinha como praticamente certa que a escolha, este ano, recairia no nome de Câmara Cascudo, principalmente porque o intelectual potiguar completou 79 anos em plena atividade de pesquisa (...) (s./a. 
"São Paulo escolhe Cascudo como intelectual do ano". In: $A$ República, 12-III-1978).

Tamanhas foram as loas proferidas a Câmara Cascudo que José Américo de Almeida tornou-se conhecedor destas notícias e, em vinte e dois de março de 1978, parabenizou o amigo potiguar "pela grande vitória com a obtenção do Prêmio Juca Pato". José Américo tinha intenção de entregar-lhe pessoalmente o prêmio, haja vista que o mesmo havia sido premiado no ano anterior, e caso seu estado de saúde não lhe permitisse viajar, mandaria seu discurso para ser lido, como havia feito Menotti Del Picchia consigo no ano anterior, saudando-o em nome da UBE:

\footnotetext{
Venho abraça-lo pela sua grande vitória com a obtenção do Pêmio Juca Pato.

Competindo com tantos valores você conquistou uma auréola que consagrou por seus extraordinários métodos de historiador e folclorista.

Terei grande alegria em transmitir-lhe o troféu em data que combinarmos. Caso meu estado de saúde não me permita viajar, mandarei o meu discurso para ser lido, como fez comigo Menotti Del Picchia, o ano passado, saudando-me em nome da UBE (JAA, 22-III1978) ${ }^{155}$.
}

Para a apoteose de Luís da Câmara Cascudo, fora escolhida a I Semana de Cultura Nordestina ocorrida entre vinte e um e vinte e seis de maio de 1978 . O evento teve culminância com homenagens feitas a Luís da Câmara Cascudo, Gilberto Freyre e José Américo de Almeida. As notas da imprensa local, em especial do jornal $A$ República, comentaram inclusive que não só Cascudo, mas que Freyre e José Américo, também seriam laureados com o título de "Doutor Honoris Causa", além da entrega do Prêmio Juca Pato a Câmara Cascudo, como poderemos observas através das transcrições realizadas a seguir:

Nesta mesma oportunidade será entregue o título de Doutor Honoris
Causa ao sociólogo e escritor Gilberto Freyre e, para o encerramento,
da instalação da I Semana de Cultura Nordestina, o madrigal da

155 No ano de 1976, José Américo de Almeida recebeu o Prêmio Juca Pato por intermédio da obra Antes que me esqueça, sendo escolhido com 311 votos. Cascudo fora premiado em 1977 com O Príncipe Maximiliano no Brasil, obtendo 323 votos. Informações obtidas por intermédio do site: http://www.amigosdolivro.com.br/lermais_materias.php?cd_materias=3232, acessado em 14/02/2016. 
UFRN estará se apresentando. Um dos temas de maior importância será apresentado na terça às 15 horas 'A Cultura Popular na obra de Luís da Câmara Cascudo', exposto pelo escritor Manuel Diégues Júnior.

(...)

Outro título de Honoris Causa será entregue aos escritores José Américo de Almeida e Luís da Câmara Cascudo, além da entrega do título ao reitor Domingos Gomes de Lima de Sócio Benemérito da Academia Norte-Riograndense de Letras. No decorrer da I Semana de Cultura Nordestina haverá apresentações de peças teatrais e shows.

(...)

Para a entrega do Prêmio Juca 'Juca Pato' da União de Escritores Brasileiros, ao escritor e historiador que reside nesta capital Luís da Câmara Cascudo, será realizada sessão solene, às 21 hs da sexta-feira na Academia Norte rio-grandense de Letras (s./a. "RN reúne por uma semana maiores expoentes da cultura nordestina". In: A República, 21-V-1978).

A I Semana de Cultura Nordestina ocorreu nas dependências do Teatro Alberto Maranhão, em Natal. Esse evento contou com a participação de vários escritores brasileiros que pensavam a cultura da região Nordeste, dentre eles, como já vimos anteriormente, os três autores a quem Moacy Cirne no jornal A República se referiu como "monstros sagrados" da região - Câmara Cascudo, Gilberto Freyre e José Américo de Almeida (SALES NETO, 2008, p.49-50) -, tal qual podemos ver a seguir:

Louve-se o esforço do jornalista Wodem Madruga na organização da Semana: debates durante o encontro, intenso programação artística, lançamento de livros, exposições de artesanato e de artes plásticas (a destacar os trabalhos de Leopoldo Nelson, J. Medeiros e Falves Silva) show de música popular apresentação de grupos folclóricos, culminando com homenagens a três 'monstros sagrados' da região (Luís da Câmara Cascudo, Gilberto Freyre e José Américo de Almeida). Além da divulgação de um manifesto, assinado por cerca de 50 nomes. Segundo alguns jornais do Rio a Semana teria sido perfeita em todos os níveis (CIRNE, 1978).

A Folha de São Paulo cobriu o evento em seu último dia, vinte e seis de maio de 1978. Segundo o correspondente, a solenidade do prêmio Juca Pato ocorreria às 21 
horas, na Academia Norte-Rio-Grandense de Letras e seria entregue por José Américo de Almeida, contando com a presença de Raimundo Menezes presidindo o momento e Francisco Rangel Pestana como representante da Folha de São Paulo, pois o evento era uma parceria estabelecida com a União Brasileira de escritores:

NATAL (Do Correspondente) - O escritor Luís da Câmara Cascudo receberá hoje às 21 horas na Academia Norte-Rio-Grandense de Letras o Troféu 'Juca Pato' por ter sido eleito o 'Intelectual do Ano de 1977' num concurso promovido pela Folha em colaboração com a União Brasileira de Escritores, seção de São Paulo. A entrega será feita por José Américo de Almeida, ganhador do troféu no ano anterior numa solenidade presidida por Raimundo de Menezes com a participação de Francisco Rangel de Pestana, representante da Folha. Cascudo é o décimo-sexto 'Intelectual do Ano' eleito em concurso de âmbito nacional, do qual participaram mais de 1200 eleitores. Pela primeira vez o 'Juca Pato' está entregue fora de São Paulo (s./a. "O Folclore Luís da Câmara Cascudo Recebe hoje em Natal o Troféu 'Juca Pato' como intelectual do ano de 1977’. In: Folha de São Paulo, 26 de maio de 1978).

A última matéria posta sobre a I Semana de Cultura Nordestina, no mês de maio, ocorreu no dia vinte e sete, um dia após a conclusão da Semana, no periódico local A República. No jornal, observa-se a seguinte chamada da matéria: "Cascudo e José Américo tiveram título da UFRN". Além do tema exposto, a matéria falou do último dia do evento, de algumas palestras como a proferida por Homero Homem, que se dedicou ao tema $O$ futebol na literatura Nordestina, como também a pronunciada por Eduardo Portella, que abordou O Nordeste na literatura Brasileira. O ponto alto da respectiva matéria foi a entrega do Prêmio Juca Pato a Cascudo, como do título de Doutor Honoris Causa ao folclorista potiguar e a José Américo de Almeida. A matéria finalizou informando que Gilberto Freyre, logo após o seu regresso, teria telegrafado ao Reitor Domingos Gomes de Lima elogiando a iniciativa:

Segundo o programa da I Semana de Cultura Nordestina, a Academia Norte-Riograndense de Letras realizou uma sessão solene às $21 \mathrm{~h}$ para entregar, o prêmio 'Juca Pato' ao escritor Luiz da Câmara Cascudo, conferido pela União de Escritores Brasileiros. Nessa mesma sessão a Universidade Federal do Rio Grande do Norte entregou o título de 
'Doutor Honoris' aos escritor[es] Luiz da Câmara Cascudo e José Américo de Almeida.

(...)

O escritor e sociólogo pernambucano Gilberto Freyre, depois de encerrar a sua participação como um dos expositores na Primeira Semana de Cultura Nordestina, enviou um telegrama ao Reitor Domingos Gomes de Lima, onde elogia a renovação que a atual administração vem dando a UFRN.

Em sua mensagem, Gilberto Freyre diz que o Campus da Universidade Federal do Rio Grande do Norte e exemplo ideal de combinação de modernidade com elogia e tradição (s./a. "Cascudo e José Américo tiveram título na UFRN”. In: A República, 27-V-1978).

Com estes aspectos tratados até agora, poderíamos pensar que tudo ocorreu conforme o que foi noticiado, e que por intermédio dos respectivos documentos aqui apresentados, teríamos "a verdadeira história" da I Semana de Cultura Nordestina. Entretanto, antes de realizarmos a coleta da correspondência de Câmara Cascudo e José Américo, tivemos a oportunidade de consultar os Anais da I Semana de Cultura Nordestina e nele percebemos algo de intrigante: em nenhuma das seções do documento, encontramos referência a pronunciamentos de José Américo de Almeida feitos no decorrer do evento. As únicas menções a José Américo ocorrem nas duas mesas-redondas que abordaram os cinquenta anos de A Bagaceira e as contribuições da obra para o romance brasileiro e o romance nordestino, presididas por Odylo Costa Filho e Juarez da Gama Batista respectivamente (ANAIS, I Semana da Cultura Nordestina, 1978, p. 253-288), conforme podemos ver a seguir:

Devo reconhecer que não é tão grande a minha dificuldade, porque José Américo é um tema muito familiar ao meu espírito. E, dentro de José Américo, 'A Bagaceira'. Cada vez que a releio a minha admiração renasce. É um livro muito importante na vida do Brasil. Não digo na vida do romance brasileiro. Porque a verdade é que os romancistas brasileiros nunca foram desgarrados do povo. Nós precisamos acabar com essa idéia de que o romance brasileiro, de que a poesia brasileira, não tinha o sabor do Brasil. (...) (COSTA FILHO, 1978, p. 255) 
É o caso do livro extraordinário, o romance que criou o romance brasileiro, e de que hoje comemoramos o cinquentenário: 'A Bagaceira', do escritor José Américo de Almeida. Vieram sendo eles, autor e obra, vagarosamente remoçados pelos anos, revigorados pelas suas constatações, madrugadoras, redescobrindo-se pelas revelações de suas redescobertas do mundo e das alternativas do humano. Que se tornaram uma riqueza sem conta, mel que se apura com um gosto de malva-rosa. Estamos lendo e redescobrindo agora mesmo este admirável 'Canto de Muro' que é a história dos nossos gestos, de uma das criaturas mais jovens deste país. Dom Luís da Câmara Cascudo, conde e barão do Potengi, protetor benefactor, senhor da cidade do Natal e territórios anexos, com respectivos gentios e instrumental, das capitanias da Paraíba, Pernambuco e seus arredores, que vão até Alagoas e ao Maranhão (DANTAS, 1978, p. 274).

As respectivas mesas redondas foram noticiadas pelo jornal local Tribuna do Norte em vinte e cinco de maio de 1978, sob o título: “Obras de José Américo em Debates nas duas mesas-redondas de hoje", nem mesmo nesta matéria houve menção direta à presença de José Américo de Almeida no respectivo evento nem que fosse para prestigiar os pronunciamentos feitos em torno de si e de sua obra. Como vimos, a apologia de José Américo de Almeida e da Bagaceira terminou por se confundir com Cascudo e seu romance Canto de Muro, por acreditarem que os autores e as respectivas obras tratam dos temas relevantes à cultura nordestina, e por tal razão deveriam ser igualmente reverenciados.

Voltando ao contexto das cartas, lembramos que na mensagem de vinte e dois de março, José Américo demonstrou que ansiava muito por participar daquele evento, de saudar o velho amigo; mas temia não poder fazê-lo devido a seu estado de saúde. E, conforme podemos perceber em carta escrita em vinte e cinco de maio de 1978, que ele não esteve durante o evento da Semana na cidade do Natal. Lamentava ter perdido o que considerou como o que poderia ter sido um dos maiores momentos de sua vida:

Você não pode avaliar como sinto não estar presente ai no seu grande dia.

Tensionava sauda-lo de improviso por estar com a vista um tanto perturbada e ser o meu forte.

Aconteceu porém que amanheci hoje doente e não tenho esperança de recuperar-me em poucos dias. 
Perco desse modo um dos maiores momentos da minha vida.

Redigi umas palavras que serão lidas pelo escritor Juarez da Gama

Batista, seu grande amigo e admirador. Ele entregar-lhe à uma copia do trabalho que foi feito na cama, sem o vigor que deveria conter.

Uma explendida noite é o que lhe desejo como mais uma etapa de sua gloriosa carreira de escritor (JAA, 25-V-1978).

Não pretendemos recontar a história da I Semana de Cultura Nordestina, o que houve foi apenas o estabelecimento de contrapontos entre as narrativas presentes nos documentos consultados e colocados para apreciação. $O$ fato é que aquela carta de Almeida enviada a Câmara Cascudo ficou guardada em seus pertences e pela alegria e tristeza do momento silenciou o ocorrido. O certo é que mesmo não estando presente em gesto, cor e forma, esteve em suas palavras, de forma magnífica, saudando a gloriosa carreira do escritor amigo.

A associação feita de Câmara Cascudo, Gilberto Freyre e José Américo de Almeida ao regionalismo tradicionalista foi ainda ratificada em momento posterior ao evento na imprensa pernambucana. Em notícia de página inteira, publicada no Jornal do Comércio, do Recife em quatro de junho de 1978, um dos participantes da I Semana de Cultura Nordestina e autor do Segundo Manifesto Regionalista, Audálio Alves, informou que o evento teria atingido um consenso entre os participantes acerca de quais rumos deveriam tomar aqueles que se interessavam pela cultura da região ${ }^{156}$. Além disso, Alves argumentou que a Semana havia discutido as bases do regionalismotradicionalista e chegado à conclusão de significativa contribuição daquele movimento para a cultura, depois de passados cinquenta anos da pregação dessas ideias em virtude dos caminhos que abrira e das repercussões que obtivera. Nesses termos, o autor do artigo, a I Semana de Cultura Nordestina teria inaugurado um novo momento da cultura brasileira: uma nova fase regionalista, que reagiria às "distorções criadas pela civilização tecnológica" da sociedade contemporânea ao evento. Mesmo que tenhamos feito a ressalva por intermédio da carta que José Américo teria enviado a Cascudo em vinte e cinco de maio de 1978; Audálio Alves, confirma a presença de Gilberto Freyre, Câmara Cascudo e José Américo, possivelmente para atribuir uma maior credibilidade à

\footnotetext{
${ }^{156}$ Conforme o argumento presente no texto do segundo Manifesto Regionalista: "Incumbe, assim, a toda a intelectualidade brasileira, e em particular a nordesti[n]a, fazer com que as produções artísticas que aqui incidam sobre essa espaço cultural não dissimulem nem esvaziem as forças do contexto vivencial que então experimentamos, com toda a significação histórica e social, a fim de que mantenhamos o conceito de área onde se embalam as grandes reservas morais e cívicas da nacionalidade" (ALVES, 1978a, p. 367).
} 
nova fase regionalista, "uma vez que os três escritores teriam estado presentes já na década de 1920" ${ }^{157}$, ou seja, teriam feito parte do Movimento RegionalistaTradicionalista, conforme vemos na passagem a seguir (SALES NETO, 2008, p. 52-53):

(...) a presença mesma, naquele Manifesto assinado pelos participantes da I SEMANA DE CULTURA NORDESTINA, de três escritores representativos da fase inicial do regionalismo, como é o caso de Gilberto Freyre, José Américo de Almeida e Luís da Câmara Cascudo, emprestou ao NOVO REGIONALISMO o caráter de continuador ou dinamizador de certas tradições, conquanto se reconheça em favor deste último, o seu cunho renovador, ao dar pela necessidade de urgentes modificações na maneira de ver e tratar as coisas do Nordeste (ALVES, 1978b).

Por fim, vemos que, este aspecto foi tão contundente para a intelectualidade norte-rio-grandense que vemos ainda em matéria apresentada no jornal A República no ano de 1979, a associação de Câmara Cascudo, Gilberto Freyre e José Américo de Almeida ao regionalismo tradicionalista freyreano irá colocar os referidos Autores em pé de igualdade como fontes inesgotáveis para tratar das coisas telúricas, do chão doméstico, do Nordeste e de sua cultura e por esta razão, Cascudo enobrecia o Rio Grande do Norte:

Realmente um homem plural, com muitas dimensões, Câmara Cascudo como Gilberto Freyre e o nosso eminente José Américo de Almeida, é tema inesgotável em que ensaístas e pesquisadores encontrarão sempre o que extrair do rico veeiro de pedras preciosas, que se contém nesse monstro sagrado que tanto enobrece o Rio Grande do Norte.

Como Gilberto Freyre e José Américo (...) Câmara Cascudo também se destaca pelo seu telurismo, visgado que ficou, por toda vida ao chão doméstico da província, em que pese a universalidade do seu espírito e da sua obra (SOARES, 1979).

\footnotetext{
${ }^{157}$ Embora tenhamos no capítulo anterior demonstrado a existência de laços de amizade entre Gilberto Freyre e José Américo de Almeida desde o início da década de 1920; não podemos dizer que o mesmo tenha participado do I Congresso Regionalista do Nordeste. Entretanto, é notória a tentativa de Freyre em associar de José Américo ao seu ideal regionalista tradicionalista, conforme constatamos na passagem a seguir: (...) "Isto sem deixar de se sugerir ter essa influência se projetado no chamado romance social do Nordeste, iniciado a seu modo com A Bagaceira, de José Américo de Almeida e depois desse início singular, tão expressivamente regionalista e tradicionalista, nas novelas de José Lins do Rêgo, Amando Fontes, Rachel de Queiroz, Jorge Amado, Graciliano Ramos” (...) (FREYRE, 1976, p. 17).
} 


\section{CONCLUSÃO:}

Para além do Modernismo e do Regionalismo: a correspondência cascudeana e novos itinerários de pesquisa

Partindo de um olhar desarmado de expectativas, buscamos perceber na epistolografia de Câmara Cascudo uma fonte promissora para um conhecimento mais aguçado da engrenagem literária do escritor potiguar junto a seus pares (LAJOLO, 2013, p. 16). A questão não foi estudar a origem do movimento modernista, tão pouco do movimento regionalista tradicionalista no Nordeste; mas tentar compreender de que maneira Câmara Cascudo estabeleceu redes de sociabilidades intelectuais com os principais representantes desses movimentos; entender seu papel intermediador, sem a necessidade de estabelecer para o mesmo um lugar ideológico definitivo.

Conforme sugeriu Ilza Matias de Sousa (2006), vemos Câmara Cascudo como um viajante da escrita e do pensamento nômade. Este aspecto pode ser comprovado ao longo desta tese, onde demonstramos o valor da correspondência para Cascudo em suas relações afetivas e intelectuais. Para aquela autora, no pensamento nômade, os nomes próprios são máscaras de ressonância. Os nomes dos eleitos presentes em Prelúdio e Fuga do Real (1974) vibram em Cascudo, fecundam-no nos diversos momentos de sua "viagem" na própria linguagem, intercruzando linhas do pensamento simbólico rico de imagens (SOUSA, 2006, p. 36).

Ainda por intermédio de Sousa, poderíamos dizer que percorrer a obra de Cascudo equivale a acompanhar seu próprio trajeto no discurso, na fala, na letra. Uma experiência que Cascudo soube elevar a um nível que transcende os epítetos de folclorista, etnógrafo, historiador, modernista ou regionalista com certo toque de bufonaria e caricatura, como forçosamente muitos querem localizá-lo na história da produção intelectual do Brasil, Nordeste e no Rio Grande do Norte. Tal um Borges, um Guimarães Rosa, ele seria um hacedor, um fazedor, um dizedor - um escritor - que está permanentemente dando suas escapadas para o silêncio, a pausa meditativa, a escuta, numa reinscrição da parte ouvinte do ser falante. Interpelando-se sobre si próprio, Cascudo responderia como Montaigne: “- Não conheço esse Homem!”. E não seria impropriedade que ele comentasse a respeito dos seus ensaios ao modo montaigniano (Id. Ibidem, p. 66-67): 
Os meus ESSAIS mereceram mais intérpretes que capítulos neles contidos. Não tive comentadores, mas colaboradores. As soluções fixadas, diluídas nos estudos cordiais parecem barro úmido nas mãos alheias. Modificam, arranjam, dispõem, remodelam. O vulto, decorrente, vai mudando de contornos na sucessão de expositores (CASCUDO, 1974, p. 75).

Dito de outro modo: Cascudo não está mais lá, não é o responsável pelas interpretações que lhe são atribuídas. $\mathrm{O}$ mesmo se ausentou antecipadamente, deixando o documento entre as mãos dos pesquisadores de sua obra. Ao menos foi o que ele declarou na passagem supracitada. A associação é livre, o que também vale para o contrato entre a escritura e a leitura deste texto com suas trocas, seus compromissos, dons, com tudo aquilo que se tenta enquanto performance interpretativa. As correspondências aqui estabelecidas como corpus desta análise foram balizadas pelo recorte histórico estabelecido e temos certeza de que os correspondentes que se indicaram por seus nomes próprios ultrapassaram amplamente tais definições, pelas razões das quais aqui nos ocupamos; demonstramos que os mesmos estiveram preocupados uns com os outros, passando todo seu tempo a se decifrarem por intermédio das redes de sociabilidades intelectuais (DERRIDA, 2007, p. 384; 397).

Ao término deste estudo, percebemos que mais do que lançar luz sobre algumas dificuldades estabelecidas pela historiografia, a correspondência estabelecida entre Câmara Cascudo e Mário de Andrade serviu como acessório, sendo buscado nas cartas aquilo que pudesse satisfazer algumas questões que vinham sendo colocadas desde o falecimento de Cascudo por Veríssimo de Melo e por quase toda a produção discursiva que lhe foi posterior.

$\mathrm{Na}$ medida em que não houve uma entrada vertical na correspondência do historiador, ela somente foi utilizada como exemplo para discussão de um ou outro ponto de vista. Tais análises caminharam na direção do estabelecimento de uma espécie de monumento, onde Luís da Câmara Cascudo ocuparia um lugar de proeminência para o Modernismo ou Regionalismo. E não se foram aprofundados os aspectos qualitativos, que a correspondência de Cascudo apresentava com generosidade, nas demais publicações de sua correspondência, que pode ser dito quanto às reflexões sobre o próprio exercício epistolar de Câmara Cascudo (AMED, 2006, p. 31-33).

Por isso, buscamos demonstrar que os documentos não são elementos inócuos para serem lidos e deles extraídos a verdade, mas são compostos pelos sentidos e 
significados a eles atribuídos. Os documentos têm uma história de sua própria constituição, como procuramos demonstrar, interferindo assim nos sentidos que eles possam oferecer. Esses sentidos são da ordem do acontecimento, pois eles se produzem num dado momento, numa dada época, num dado contexto, podendo inclusive silenciar outras séries documentais que de uma forma ou de outra contradigam o discurso que se quer estabelecer enquanto regime de verdade; foi o caso das publicações da correspondência de Cascudo enviadas para Thadeu Villar de Lemos, João Lyra Filho e Oswald Lamartine.

Através de um estudo da epistolografia de Luís da Câmara Cascudo com Mário de Andrade, Joaquim Inojosa, Gilberto Freyre e José Américo de Almeida de 1922 a 1984, buscamos transpor o debate historiográfico estabelecido em torno da tentativa de delimitação da produção intelectual do escritor potiguar presa ao Movimento Modernista ou ao Movimento Regionalista Tradicionalista do Nordeste. Ao reconstituir as redes de sociabilidades intelectuais estabelecidas nos arquivos da criação dos mesmos, verificamos as estratégias utilizadas por Cascudo para se relacionar de forma amistosa com os representantes dos respectivos movimentos.

Averiguamos as táticas empregadas por Cascudo no intuito de fazer circular suas ideias e obras no circuito editorial gerenciado pelo Modernismo e pelo Regionalismo tradicionalista na região Nordeste e no Brasil. Contribuímos com a elaboração de novos itinerários biográficos em especial do crítico literário presente na epistolografia cascudeana, como também nos artigos e noutras obras do respectivo contexto em análise. Procuramos compreender, de maneira circunstanciada, as relações complexas existentes na historiografia do Regionalismo e do Modernismo no contexto da modernização da região Nordeste, analisando as atitudes dos atores envolvidos no processo, assim como as contradições neles implicadas.

Buscamos colocar a discussão sobre a epistolografia cascudeana em outros termos, abrindo a possibilidade de novos itinerários de pesquisa. Pretendemos posteriormente aprofundar alguns aspectos aqui apresentados. Como por exemplo, buscar catalogar as cartas dos interlocutores supracitados que foram enviadas a Câmara Cascudo, na tentativa de mapear o projeto de publicação sobre A Geografia da Superstição no Brasil, com a finalidade de descobrir quem seriam os outros interlocutores convidados para compor o respectivo projeto. Teriam enviado suas contribuições? Por quais razões a obra não foi ao prelo? 
Do mesmo modo nos interessa verificar a existência das cartas que Cascudo enviou a Monteiro Lobato, Rocha Pombo, Pedro de Orleans e Bragança e Guilherme Auler. No entanto, tal proposta de pesquisa precisa ter ao menos comprovada sua viabilidade, ou seja, a existência dos arquivos documentais dos referidos interlocutores e onde estariam sendo preservados.

Outro tema a que gostaríamos de dar maior atenção diz respeito à relação de Cascudo com os escritores Sanchez-Paes e Luís E. Soto, na tentativa de compreender melhor como ocorreu a aproximação de Cascudo com ambos e dos temas abordados nas respectivas correspondências. Este último, como o primeiro dos demais interesses aqui apresentados, são viáveis pela existência e preservação das séries destas correspondências no Ludovicus - Instituto Câmara Cascudo.

Com a abertura do respectivo acervo, uma infinidade de novas pesquisas deverá ser desenvolvida muito em breve.

Esperamos, por fim, que esta tese possa contribuir para o debate sobre Câmara Cascudo e seus companheiros de trajeto. 


\section{Referências Bibliográficas:}

\subsection{Fontes}

\subsubsection{Impressas}

\subsubsection{Livros e Artigos}

ANDRADE, Ana Isabel de Souza Leão. Catálogo da correspondência de José Américo de Almeida. João Pessoa, PB: Fund. Casa de José Américo, 1983.

ANDRADE, Mário de. Correspondência Mário de Andrade \& Manuel Bandeira. Organização, introdução e notas Marcos Antonio de Moraes. $2^{a}$ ed. São Paulo, Editora da Universidade de São Paulo, 2001.

Cartas de Mário de Andrade a Luis da Câmara Cascudo. Introdução e notas, Veríssimo de Melo. Belo Horizonte, Editora Itatiaia, 2000.

A lição do guru - cartas a Guilherme de Figueiredo (1937-1945). Marta

Rossetti Batista (org.). Rio de Janeiro: Civilização Brasileira, 1989.

. Vida Literária. São Paulo: Hucitec; EDUSP, 1993.

. O turista aprendiz. São Paulo: Duas Cidades: Secretaria da Cultura, Ciência e

Tecnologia, $2^{\text {a }}$ ed. 1983.

. O movimento modernista. In: Aspectos da literatura brasileira. $6^{a}$ ed. São Paulo: Martins, 1978, p. 231-255.

Táxi e crônicas no Diário Nacional. São Paulo: Duas Cidades; Secretaria de

Cultura, Ciência e Tecnologia de SP, 1976.

. Modernismo. In: O empalhador de passarinho. $3^{\text {a }}$ ed. São Paulo; Brasília: Martins/INL, 1972. p. 185-189.

ALMEIDA, José Américo de. A Bagaceira. 37ª ed. Rio de Janeiro: José Olympio Editora, 2004.

A Paraíba e seus Problemas. $3^{\text {a }}$ ed. João Pessoa, PB: A União, 1984.

O Ano do Nego - memórias. João Pessoa, PB: A União, 1978.

Reflexões de uma cabra. Rio de Janeiro: Editora Leitura, 1971.

Graça Aranha - o doutrinador. João Pessoa, PB: UFPB/Dept. Cultural, 1968.

ALVES, Audálio. Manifesto. In: Semana de Cultura Nordestina, 1, Natal, 1978. Anais. Natal, Ed. Universitária, 1979. p. 365-369. 
BRITO, Raimundo Soares de. Apostilas do Afeto: Câmara Cascudo. Mossoró, RN: Coleção Mossoroense. Série C - Vol. CCCXXXVI, 1986.

CAVALHEIRO, Edgar (org.). Testamento de uma geração. Porto Alegre, RS: Globo, 1944.

CASCUDO, Luís da Câmara. Câmara Cascudo e Mário de Andrade: cartas 19241944. Marcos Antonio de Moraes (org.). São Paulo: Global, 2010a.

Gente Viva. 2a ${ }^{\text {a }}$ Ed. Natal, RN: EDUFRN, $2010 b$.

Nosso amigo Castriciano (1874-1947). Natal, RN: EDUFRN, 2008a.

Vida Breve de Auta de Souza: 1876-1901. Natal: EDUFRN, 2008b.

. Crônicas de origem: a cidade do Natal nas crônicas cascudianas dos anos

20. Raimundo Arrais (org.). Natal: Ed. da UFRN, 2005a.

Flama serena: cartas de Luís da Câmara Cascudo a João Lyra Filho.

Organização, introdução e notas de Roberto da Silva. Natal: Sebo Vermelho, 2005b.

Vaqueiros e cantadores: folclore poético do sertão de Pernambuco,

Paraíba, Rio Grande do Norte e Ceará. São Paulo: Global, 2005c.

História da Alimentação no Brasil. $3^{\text {a }}$ ed. São Paulo: Global, 2004.

. Luis, toujours lui: cartas de Câmara Cascudo a Bernard Alléguède.

Organização, introdução e notas de Roberto da Silva. Natal: Sebo Vermelho, 2002.

. Superstição no Brasil. $4^{\mathrm{a}}$ ed. São Paulo: Global, 2001.

. Alma Patrícia: crítica literária. $2^{\mathrm{a}}$ ed. Natal, RN: Fundação José Augusto, 1998a.

Na ronda do tempo: diário de 1969. 2. ed. Natal: Ed. da UFRN, 1998 b.

. Ontem: maginações e notas de um professor de província. 2. ed. Natal: Ed. da UFRN, 1998c.

López do Paraguay. Edição fac-similar. Mossoró, RN: Fundação Vingt-un Rosado, 1995.

Viajando o Sertão. Edição fac-similar. Mossoró, RN: Fundação Vingt-un Rosado, 1992.

. Joio: páginas de literatura e crítica. Edição fac-similar. Mossoró, RN: Fundação Vingt-un Rosado, 1991a.

Histórias que o tempo leva... da história do Rio Grande do Norte.

Edição fac-similar. Mossoró, RN: Fundação Vingt-un Rosado, 1991 b. 
Antologia da Alimentação no Brasil. Rio de Janeiro: Livros Técnicos e Científicos, 1977.

Prelúdio e Fuga do Real. Natal, RN: Fund. José Augusto, 1974.

. Sociologia do Açúcar. Rio de Janeiro: MIC/Inst. do Açúc. e do Alc. 1971.

- Pequeno manual do doente aprendiz: notas e imaginações. Natal, RN:

EDUFRN, 1969.

O tempo e eu: confidências e proposições. Natal, RN: EDUFRN, 1968.

Conde d'Eu. 1. ed. São Paulo: Companhia Editora Nacional, 1933.

COSTA, Américo de Oliveira. Viagem ao universo de Câmara Cascudo. 1. ed. Natal: Fundação José Augusto, 1969.

COSTA FILHO, Odylo. 50 anos de A Bagaceira: Américo e o romance brasileiro. In: In: Semana de Cultura Nordestina, 1, Natal, 1978. Anais. Natal, Ed. Universitária, 1979. p. 253-264.

DANTAS, Paulo. 50 anos de A Bagaceira. J. A. A. e o romance nordestino. In: Semana de Cultura Nordestina, 1, Natal, 1978. Anais. Natal, Ed. Universitária, 1979. p. 282283.

FERREIRA, Ascenso. Meu depoimento. In: CAVALHEIRO, Edgar (org.). Testamento de uma geração. Porto Alegre, RS: Globo, 1944.

FREYRE, Gilberto. Nordeste. 6. ed. Rio de Janeiro: Record, 1989.

. (org.) Livro do Nordeste. $2^{\mathrm{a}}$ ed. Edição fac-similar. Recife: Arquivo Público Estadual, 1979a.

Tempo de aprendiz: artigos publicados em jornais na adolescência e na primeira mocidade do autor, 1918 a 1926. Organizado por José Antônio Gonsalves de Mello. São Paulo: IBRASA, 1979b. 2v.

. "José Américo de Almeida uma reinterpretação". In: ALMEIDA, José Américo de. A Bagaceira, 15a ed. Rio de Janeiro, José Olympio, Secretaria de Educação e Cultura da Paraíba, 1978. p. 91-103.

Manifesto Regionalista. $6^{\mathrm{a}}$ ed. Recife, PE: MEC/ Inst. Joaquim Nabuco, 1976.

Tempo morto e outros tempos: trechos de um diário de adolescência e primeira mocidade (1915-1930). Rio de Janeiro: José Olympio, 1975.

Região e Tradição. $2^{\text {a }}$ ed. Rio de Janeiro: Record, 1968.

INOJOSA, Joaquim. A arte moderna: 60 anos de um manifesto modernista. Rio de Janeiro: Editora Cátedra, 1984. 
Sursum corda! - desfaz-se o "equívoco" do manifesto regionalista de 1926. Rio de Janeiro: s/e, 1981.

. José Américo de Almeida: algumas cartas. Rio de Janeiro: s/e, 1980.

. 60 anos de jornalismo (1917-1977). Rio de Janeiro: Editora Meio-Dia, 1978a.

. Pá de cal. Rio de Janeiro: Editora Meio-Dia, 1978b.

. Os Andrades e outros aspectos do modernismo. Rio de Janeiro:

Civilização Brasileira; Brasília: Instituto Nacional do Livro/Ministério da Educação e Cultura, 1975a.

. Notícia Biobliográfica de Joaquim Inojosa. Rio de Janeiro: Ed. Meio-Dia, 1975b.

. Carro Alegórico - nova resposta a Gilberto Freyre. Rio de Janeiro: Ed. do Autor, 1973.

O movimento modernista em Pernambuco. Rio de Janeiro: Editora Tupy, 1969. v. 3.

. O movimento modernista em Pernambuco. Rio de Janeiro: Editora Tupy, 1968a. v. 2.

. O movimento modernista em Pernambuco. Rio de Janeiro: Editora Tupy, 1968a. v. 1.

. No pomar vizinho. Rio de Janeiro: Ed. do Autor. 1968b.

LAMARTINE DE FARIA, Oswaldo. De Cascudo para Oswaldo. Natal: Sebo Vermelho, 2005.

LEMOS, Thadeu Villar de. Mensagens de Câmara Cascudo e Cosme Lemos. Rio de Janeiro: Editora Pongetti, 1972.

MELO, Veríssimo de. (Org.). Cartas de Mário de Andrade a Luís da Câmara Cascudo. Belo Horizonte: Itatiaia, 2000.

. Epistolografia no mês de Mário. In: Múltiplo Mário: Ensaios. Maria I. N. Ayala e Eduardo de Assis Duarte (org.). João Pessoa/ Natal: EDUFPB/EDUFRN, 1997. p. $157-163$.

(org.). Cartas e cartões de Oswald Lamartine. Natal, RN: Fund. José Augusto, 1995.

. Cascudo: o escritor de cartas. Brasília: Ed. Thesaurus, 1993a.

. Leitura crítica das cartas de Mário de Andrade a Câmara Cascudo. In: Ci. \& Tróp., Recife, PE: v.21, n.1, p. 45-66, 1993 b. 
A obra folclórica de Cascudo como expressão do movimento modernista

no Brasil. 2. ed. Mossoró: Fundação Vingt-un Rosado, 1989a.

(org.). Cartas de Ascenso Ferreira. Natal, RN: ANRL; Nordeste Gráfica

Ltda, 1989b.

Contribuição do Nordeste ao movimento modernista. Natal: Fundação José Augusto, 1971.

Semana de Cultura Nordestina, 1, Natal, 1978. Anais. Natal, Ed. Universitária, 1979.

VASCONCELOS, Francisco de. Câmara Cascudo: do Potengi ao Piabanha. Natal/ Petropólis, Ed. do autor, 1989.

\subsection{Artigos de Jornais:}

ALVES, Audálio. Fundamentos de um manifesto à Nação. In: Jornal do Comércio, Recife, 04 de junho de 1978.

CASCUDO, Luís da Câmara. Cigalhos... a propósito do numerário de Gilberto Freyre. In: A Imprensa, Natal, 15 de junho, 1923.

De Recife: a bengala de Gilberto Freyre. A Imprensa, Natal, 14 março, 1924. Responder cartas... In: A República, Natal, 7 de julho de 1943.

CASTRICIANO, Henrique. Uma figura literária do Nordeste: Nísia Floresta. In: FREYRE, Gilberto. (org.) Livro do Nordeste. $2^{\mathrm{a}}$ ed. Edição fac-similar. Recife: Arquivo Público Estadual, 1979a, p. 138-139.

CIRNE, Moacy. Sobre a $1^{\text {a }}$ Semana de Cultura Nordestina. In: A República, Natal, 16 de julho, 1978.

MELO, Veríssimo. A Obra folclórica de Cascudo. In: A República, Natal, RN, 26 de outubro de 1986.

RÊGO, José Lins. Seca no Nordeste. In: A União, PB, 16 de março de 1951, p. 3.

s./a. Cascudo não acredita no prêmio - TV e Jornal dizem que Câmara Cascudo ganhou o Juca Pato. In: A República, 25 de fevereiro de 1978.

s./a. Câmara Cascudo é Doutor Honoris Causa da UFRN In: A República, 05 de março de 1978

s./a. "São Paulo escolhe Cascudo como intelectual do ano". In: A República, 12 de março de 1978

s./a. "RN reúne por uma semana maiores expoentes da cultura nordestina". In: A República, 21 de maio de 1978. 
s./a. "O Folclore Luís da Câmara Cascudo Recebe hoje em Natal o Troféu 'Juca Pato' como intelectual do ano de 1977’. In: Folha de São Paulo, 26 de maio de 1978

s./a. "Cascudo e José Américo tiveram título na UFRN". In: A República, 27 de maio de 1978

s/a. Câmara Cascudo celebra 60 anos de jornalismo na imprensa potiguar. In: A República, Natal, RN, 20 de outubro de 1978. s/p.

SOARES, Epitácio. Câmara Cascudo em dois tempos. In: A República, Natal, 27 de outubro de 1979.

SOUZA, Eloy de. Os último cantadores do Nordeste. In: FREYRE, Gilberto. (org.) Livro do Nordeste. $2^{\text {a }}$ ed. Edição fac-similar. Recife: Arquivo Público Estadual, 1979a, p. 66-67.

\subsubsection{Manuscritas}

\subsubsection{Correspondências}

\subsubsection{Ativa Cascudo}

Gilberto Freyre (1925-1978).

José Américo de Almeida (1952-1978).

Joaquim Inojosa (1924-1984).

Mário de Andrade (1924-1944).

\section{1.4.3. Passiva Cascudo}

Gilberto Freyre (1923-1986).

Guilherme Auler (1942-1962)

José Américo de Almeida (1922-1978)

Joaquim Inojosa (1926-1984)

Mário de Andrade (1924-1943)

Monteiro Lobato (1920-1944)

Pedro de Orleans Bragança (1924-1938)

Rocha Pombo (1920-1928)

Veríssimo de Melo (1979) 


\subsection{Bibliografia Geral:}

Albuquerque JR, Durval Muniz de. A Feira dos Mitos: A Fabricação do Folclore e da Cultura Popular (Nordeste: 1920-1950). Apresentação Regina Horta Duarte. São Paulo: Intermeios, 2013a, 246p.

Raros e rotos, restos, rastros e rostos: os arquivos e documentos como condição de possibilidade do discurso historiográfico. In: ArtCultura, Uberlandia, v. 15, n. 26, p. 7-28, jan-jun, 2013b. p. 8-28.

. Uma projeção lírica, uma poesia recordadora: o Nordeste de Câmara Cascudo.

In. Câmara Cascudo e os Saberes/ Marcos Silva (org.) Rio de janeiro: Fundação Miguel de Cervantes, 2013c, p. 108-123

A Invenção do Nordeste e Outras Artes. Prefácio de Margareth Rago. 5a . Ed. São Paulo: Cortez, 2011.

AMED, Fernando. As cartas de Capistrano de Abreu: sociabilidade e vida literária na belle époque. São Paulo: Alameda, 2006.

AMOROSO, Marta. Os sentidos da etnografia em Câmara Cascudo e Mário de Andrade. In: Revista IEB, São Paulo, n. 54, p. 177-182, 2012.

ARAÚJO, Humberto Hermenegildo de. Consciência Moderna e Movimentos: o modernismo nas cartas trocadas entre Câmara Cascudo e Joaquim Inojosa. Relatório Final de Estágio de Pós-Doutorado. PPGTLLC/ FFLCH - USP. São Paulo, 2012, 162p.

A Moderna Ocasião: posicionamentos cascudianos no inicio do século XX. In.

Imbuarana - Revista do Núcleo Câmara Cascudo de Estudos Norte - Rio Grandenses/ UFRN, n. 3, fev./ jun. 2011, p. 84-118.

[et al.]. A escritura epistolar de Câmara Cascudo. In: Vozes e reflexões:

Anais do I Encontro Natalense de Escritores. Natal: Fundação Capitania das Artes, 2007. p. 243-272.

Mário de Andrade/ Câmara Cascudo: cartas de brasilidade. In: Múltiplo

Mário: Ensaios. Maria de Ignez Novais Ayala e Eduardo de Assis Duarte (org.). João Pessoa/ Natal: EDUFPB/EDUFRN, 1997, p. 199-206.

Modernismo: anos 20 no Rio Grande do Norte. Natal: Ed. da UFRN, 1995. ARÓSTEGUI, Julio. A pesquisa histórica: teoria e método. Bauru, SP: Edusc, 2006. 
ARRAIS, Raimundo. Estudo introdutório: O nascimento do cronista e o nascimento da cidade de Natal. In: CASCUDO, Luís da Câmara. Crônicas de origem: a cidade do Natal nas crônicas cascudianas dos anos 20. Raimundo Arrais (org.). Natal: Ed. da UFRN, 2005, p. 9-80.

ARRUDA, Maria Arminda do Nascimento. Modernismo e regionalismo no Brasil entre a inovação e a tradição. In: Tempo Social - revista de sociologia da USP, São Paulo, v. 23, n. 2, p. 191-212, 2011.

ARTIÈRES, Philippe. Arquivar a própria vida. Rio de Janeiro: CPDOC, 1998. Disponível em: <http://www.cpdoc.fgv.br/revista/>. Acesso em: 09 abr. 2007.

ARTUNDO, Patrícia. Mário de Andrade e a Argentina: um país e sua produção cultural como espaço de reflexão. São Paulo: EDUSP, 2008.

ASSIS, Guaracy Medeiros de. "'A Paraíba pequenina e doida’: José Américo e a Revolução de 30”. Dissertação de Mestrado. Recife, PE: PPGH/UFPE, 2005.

AZEVEDO, Neroaldo Pontes de. Modernismo e Regionalismo: os anos 20 em Pernambuco. 2. ed. João Pessoa: Ed. da UFPB; Recife: Ed. da UFPE, 1996.

BARROS, Natália Conceição Silva. Arquivos da vida, Arquivos da História: as experiências intelectuais de Joaquim Inojosa e os usos da memória do Modernismo. Tese de Doutorado. Recife, PE: PPGH/UFPE, 2012, mímeo.

BARBOSA, Jivago Correia. Política e assistencialismo na Paraíba: o governo de José Américo de Almeida. Dissertação de Mestrado. João Pessoa, PB: PPGH/UFPB, 2012.

BORDINI, Maria da Glória. Acervos de escritores e o descentramento da história da literaturall. In: O eixo e a roda, v. 11, 2005, Belo Horizonte: UFMG, p. 15-23.

BOURDIEU, Pierre. A economia das trocas simbólicas. São Paulo: Perspectiva, 2007. A ilusão biográfica. Usos \& abusos da história oral/ Janaína Amado e marieta de Moraes Ferreira, (orgs.). 8ª ed. Rio de Janeiro: EDFGV, 2006, p. 183-192.

BRITTO, Jomard Muniz. Prelúdio e Fuga do Real. In: SILVA, Marcos. (Org.) Dicionário Crítico Câmara Cascudo. São Paulo: Perspectiva, FFLCH/USP, FAPESP; Natal: EDUFRN, Fund. José Augusto, 2003. p. 241-243.

BYINGTON, Silvia. Pentimentos modernistas: as cores do Brasil na correspondência entre Luís da Câmara Cascudo e Mário de Andrade. Dissertação de Mestrado. Departamento de História. PUC-RJ. 2000. Mímeo.

CARDOSO, Marília Rothier. Jogo de cartas, uma leitura da correspondência de Machado de Assis. In: O Eixo e a roda, Belo Horizonte, MG: n. 4, p. 59-70, 1985. 
CASTRO, Marize Lima de. Areia sob os pés da alma: uma leitura da vida e obra de Oswaldo Lamartine de Faria. PPGEL/UFRN, Natal, RN, 2015. Mímeo.

CHAGURI, Mariana. O romancista e o engenho: José Lins do Rêgo e o regionalismo nordestino dos anos 1920 e 1930. São Paulo: Aderaldo \& Rothschild; ANPOCS, 2009. CORÇÃO, Mariana. Câmara Cascudo, o “provinciano incurável”: desvendando os caminhos de História da Alimentação no Brasil. Tese de Doutorado. Curitiba, UFPR, 2014. Mímeo.

CORREIA, Francisco José Gomes. O sacrifício e as cartas em Mário de Andrade. In: Múltiplo Mário: Ensaios. Maria de Ignez Novais Ayala e Eduardo de Assis Duarte (org.). João Pessoa/ Natal: EDUFPB/EDUFRN, 1997, p. 191-198.

D'ANDREA, Moema Selma. A Tradição Re(des)coberta: o pensamento de Gilberto Freyre no contexto das manifestações culturais e literárias nordestinas. $2^{\mathrm{a}}$. Ed. Revista e ampliada. Campinas, SP: EDUNICAMP, 2010, 239p.

DIAZ, José Luis. Qual a Genética para as Correspondências? Trad. Claudio Hiro e Maria Sílvia B. Ianni). In. Manuscrítica. Revista de Crítica Genética. São Paulo, n.15, 2007, p. 119-162.

DIMAS, Antonio. Um manifesto guloso. In: Légua \& meia: Revista de literatura e diversidade cultural. Feira de Santana: UEFS, v. 3, n², 2004, p. 7-24.

DERRIDA, Jacques. O cartão-postal de Sócrates a Freud e além. Rio de Janeiro: Civilização Brasileira, 2007.

EL FAR, Alessandra. A encenação da imortalidade: uma análise da Academia Brasileira de Letras nos primeiros anos da República (1897-1924). Rio de Janeiro: EDFGV, 2000.

FERREIRA, José Luiz. Câmara Cascudo na Revista do Brasil. In: Memórias de contiguidades: leituras sobre textos de autores potiguares em periódicos do século XX. Humberto Hermenegildo Araújo \& Derivaldo dos Santos (orgs.). João Pessoa/Natal: Ideia/EDUFRN, 2013, p. 125-148.

Aspectos da ação intelectual de Câmara Cascudo nos anos de 1920. In.

Imbuarana - Revista do Núcleo Câmara Cascudo de Estudos Norte-RioGrandenses/ UFRN, n. 3, fev./ jun. 2011, p. 48-83.

Gilberto Freyre e Câmara Cascudo: perspectivas do elemento regional. In:

Regionalismo, modernização e crítica social na literatura brasileira/ Humberto Hermenegildo de Araújo \& Irenísia Torres de Oliveira (orgs.). São Paulo: Nankin, 2010. p. 111-140. 
Gilberto Freyre e Câmara Cascudo: entre a tradição, o moderno e o regional. Tese de Doutorado. Natal: PPGEL/UFRN, 2008, Mímeo.

Modernismo e tradição: leitura da produção literária de Câmara Cascudo

nos anos 20. 2000. 135p. Dissertação (Mestrado em Letras) - Departamento de Letras, Universidade Federal do Rio Grande do Norte, Natal, 2000.

FIGUEIREDO JR., Nestor Pinto de. Pela Mão de Gilberto Freyre ao Menino de Engenho: cartas. Apresentação e Estudo. João Pessoa: Idéia, 2000, 267p.

FOUCAULT, Michel. A arqueologia do saber. Luiz Felipe Baeta Neves (trad.). $7^{\mathrm{a}}$ ed. Rio de Janeiro: Forense universitária, 2007.

O que é um autor? Lisboa: Vega, 1992.

GAlvão, Claudio Augusto Pinto. Alguns Compassos - Câmara Cascudo e a música (1920-1960). Tese de Doutorado. PPGHS/USP, 2010, Mímeo.

GALVÃO, Dácio Tavares de Freitas. O poeta Câmara Cascudo: um livro no inferno da biblioteca. Tese de Doutorado. Natal: PPGEL/UFRN, 2012. Mímeo.

GICO, Vânia. Itinerário de um pensador. PUC/ SP - Programa de pós-graduação em Ciências Sociais, Tese, 1998, Mímeo.

GIUCCI, Guillermo; LARRETA, Enrique Rodríguez. Gilberto Freyre - Uma biografia cultural: a formação de um intelectual brasileiro (1900-1936). Rio de Janeiro: Civilização Brasileira, 2007.

GOMES, Ana Laudelina Ferreira. Introdução: Vida, obra e ressonância de Auta de Souza. In: SOUZA, Auta. Horto, outros poemas e ressonâncias: obras reunidas. Natal, RN: EDUFRN, 2009, p. 15-20.

Auta de Souza: representações culturais e imaginação poética. Tese de Doutorado. PPGCS/PUC-SP, 2000, mímeo.

GOMES, Angela de Castro. (Org.). Em família: a correspondência de Oliveira Lima e Gilberto Freyre. Campinas: Mercado de Letras, 2005.

(Org.). Escrita de si, escrita da história. Rio de Janeiro: Fundação Getúlio Vargas, 2004.

. Em família: a correspondência entre Oliveira Lima e Gilberto Freyre. In: - (Org.). Escrita de si, escrita da história. Rio de Janeiro: Fundação Getúlio Vargas, 2004, p. 51-76.

. "Nas Malhas do Feitiço: o Historiador e os Encantos dos Arquivos Privados" In: Estudos Históricos. Rio de Janeiro, 1998, v.11, n. 21, p. 121-127. 
Essa Gente do Rio... Os intelectuais cariocas e o modernismo. In. Estudos Históricos. Rio de Janeiro, v.6, n. 11, 1993, p. 62-77.

GOMES, Edna Maria Rangel de Sá. Correspondências: leitura das cartas trocadas entre Luís da Câmara Cascudo e Mário de Andrade. 1999. 354p. Dissertação (Mestrado em Letras) - Departamento de Letras, Universidade Federal do Rio Grande do Norte, Natal, 1999.

GUIMARÃES, Lúcia Maria Paschoal; ARAÚJO, Valdei Lopes de. O sistema intelectual brasileiro na correspondência passiva de John Casper Branner. In: GOMES, Angela de Castro. (Org.) Escrita de si, escrita da história. Rio de Janeiro: Fundação Getúlio Vargas, 2004, p. 93-110.

HALLEWELL, Laurence. O livro no Brasil. São Paulo: T. A. Q. Editor; EDUSP, 1985.

IONTA, Marilda. Oneyda Alvarenga escreve a Mário de Andrade. In: Rev. IEB, São Paulo, n. 37, p. 161-180, dez, 2013.

A escrita de si como prática de uma literatura menor: cartas de Anita Malfatti a Mário de Andrade. In: Estudos Feministas, Florianópolis, 19 (1): 312, jan/abril, 2011. As cores da Amizade: cartas de Anita Malfatti, Oneyda Alvarenga, Henriqueta Lisboa e Mário de Andrade. São Paulo: Annablume; FAPESP, 2007.

KOSELLECK, Reinhart. Futuro passado: contribuição à semântica dos tempos históricos. Rio de Janeiro: Contraponto; EDPUC-Rio, 2006.

LAJOLO, Marisa. "Monteiro Lobato e Câmara Cascudo: correspondência, história e teorias literárias". In. Câmara Cascudo e os Saberes/ Marcos Silva (org.) Rio de janeiro: Fundação Miguel de Cervantes, 2013, p. 14-31.

LE GOFF, Jacques. História e memória. 4. ed. Campinas: Ed. da UNICAMP, 1996. (Coleção Repertórios).

LIMA, Marinalva Villar de. Voz de Nessus. In: SILVA, Marcos. (Org.) Dicionário Crítico Câmara Cascudo. São Paulo: Perspectiva, FFLCH/USP, FAPESP; Natal: EDUFRN, Fund. José Augusto, 2003. p. 303-306.

LIMA, Matheus Silveira. Percurso intelectual de Luís da Câmara Cascudo: modernismo, folclore e antropologial. In: Perspectivas, São Paulo, v. 34, p. 173-192, jul./dez. 2008.

LOPES, Beatriz; GOMES, André Luís. Cultura popular nos arquivos de Mário de Andrade: Na Pancada do Ganzá e os Fundos Villa-Lobos. In: Signo, Santa Cruz do Sul, v. 39, n. 66, p. 164-186, 2014. 
MACHADO, Marcia Regina Jaschke. O Modernismo dá as cartas: circulação de manuscritos e produção de consensos na correspondência de intelectuais nos anos de 1920. Tese de Doutorado. São Paulo: PPGLB/USP, 2012, mímeo.

MAMEDE, Zila. Luís da Câmara Cascudo, 50 Anos de vida intelectual, 1918-1968. Natal: Fundação José Augusto, 1970. 2v.

MALATIAN, Teresa. "Cartas: Narrador, Registro e Arquivo". In. O Historiador e suas Fontes/ Carla B. PINSKY e Tania Regina de Luca (org.). São Paulo: Contexto, 2011, p. 195-221.

MARSON, Izabel Andrade. O(s) império (s) de Câmara Cascudo. In: Câmara Cascudo e os Saberes/ Marcos Silva (org.) Rio de janeiro: Fundação Miguel de Cervantes, 2013, p. 80-107.

MATTOS, Hebe Maria; GRINBERG, Keila. Lapidário de si: Antonio Pereira Rebouças e a escrita de si. In: GOMES, Angela de Castro. (Org.) Escrita de si, escrita da história. Rio de Janeiro: Fundação Getúlio Vargas, 2004, p. 27-50.

MICELI, Sergio. Vanguardas em retrocesso: ensaios de história social e intelectual do modernismo latino-americano. São Paulo: Companhia das Letras, 2012.

Nacional estrangeiro: história social e cultural do modernismo artístico em São Paulo. São Paulo: Companhia das Letras, 2003.

MEDEIROS, Joatan David Ferreira. Câmara Cascudo e os latinos da América: diálogos culturais na década de 20. In: Imburana - Revista do Núcleo Câmara Cascudo de Estudos Norte-Rio-Grandenses/UFRN, Natal, n. 6, 2012, p. 85-95. Disponível em: < http://www.periodicos.ufrn.br/imburana/article/view/5098/4083>, Acessado em 10 de abril de 2014.

MORAES, Marcos Antônio de. "Acordes, contrapontos: Entrecruzamentos biobibliográficos de Cascudo e Mário”. In. Câmara Cascudo e Mário de Andrade: cartas (1924-1944)/ pesquisa documental/ iconográfica, estabelecimento de textos e notas Marcos Antônio de Moraes (org.), São Paulo: global, 2010, p. 370-383.

Orgulho de Jamais Aconselhar: a epistolografia de Mário de Andrade. São Paulo: EDUSP; FAPESP, 2007a.

“Epistolografia e crítica genética”. In. Ciência \& Cultura v.59 n.1 São Paulo jan./mar. 2007b, p.30-32.

Afinidades Eletivas. In: Correspondência Mário de Andrade e Manuel Bandeira. Marcos Antônio de Moraes (org.). São Paulo: EDUSP/IEB, USP, $2^{\text {a }}$ ed. 2001, p. 13-44. 
Carta, testemunho e biografia. In: Múltiplo Mário: Ensaios. Maria de Ignez

Novais Ayala e Eduardo de Assis Duarte (org.). João Pessoa/ Natal: EDUFPB/EDUFRN, 1997, p. 185-190.

NEVES, Margarida de Souza. Na ronda do tempo. Luís da Câmara Cascudo, historiador. In: Câmara Cascudo e os Saberes/ Marcos Silva (org.) Rio de janeiro: Fundação Miguel de Cervantes, 2013, p. 124-147.

Viajando o sertão: Luís da Câmara Cascudo e o solo da tradição. In: CHALHOUB, Sidney; NEVES, Margarida de Souza; PEREIRA, Leonardo Affonso de Miranda. História em cousas miúdas. Campinas: Editora da Unicamp, 2005. p. 237262.

Artes e ofícios de um “provinciano incurável”. In: Projeto História, São Paulo, 24, 2002, p. 65-85.

NORA, Pierre. Entre Memória e História: a problemática dos lugares. In: Projeto História, São Paulo, 10, 1993, p. 7-28.

OLIVEIRA, Aluízio Lins. Erudição e cultura popular na atividade intelectual de Luís da Câmara Cascudo. Tese de Doutorado. São Paulo: FFLCH/USP, 2012. Mímeo. OLIVEIRA, Giuseppe Roncalli Ponce Leon de. Luís da Câmara Cascudo e a invenção do feminino na cultura-popular-nordestina (1938-1977). Campina Grande, PB: EDUFCG, 2009.

PALLARES-BURKE, Maria Lúcia Garcia. Gilberto Freyre: um vitoriano nos trópicos. São Paulo: EDUNESP, 2005.

PASSOS, Marie Hélène-Paret. Entre vida real e criação: a correspondência como reservatório da ficção. In: Letras de Hoje. Porto Alegre, v. 49, n. 2, p. 190-194, 2014.

PINHEIRO, Maria Lucia Bressan. Origens da noção de preservação do Patrimônio cultural no Brasil. In: Arte \& Risco, São Paulo, v. 3, n. 2, 2006.

PENA, Felipe. Jornalismo literário. São Paulo: Cosac Naif, 2004.

RIBEIRO, Marília Andrés. O modernismo brasileiro: arte e política. In: ArtCultura, Uberlândia, v. 9, n. 14, p. 115-125, 2007.

SALES NETO, Francisco Firmino. Luís Natal ou Câmara Cascudo: o autor da cidade e o espaço como autoria. Dissertação de Mestrado. Natal: PPGH/UFRN, 2009, mímeo.

Palavras que silenciam: Câmara Cascudo e o regionalismo-tradicionalista nordestino. João Pessoa: Ed. da UFPB, 2008. 
Narrativas de uma vida, escrita da história: (re) pensando a exaltação biográfica da experiência modernista do escritor Luís da Câmara Cascudo. Disponível em: <http://anpuh.org/anais/wp-content/uploads/mp/pdf/ANPUH.S24.0816.pdf>, acessado em $02 / 06 / 15$.

SANTINI, Juliana. Realidade e representação no romance regionalista brasileiro: tradição e atualidade. In: O eixo e a roda, Belo Horizonte, MG: v. 23, n. 1, p. 115-131, 2014.

SANTOS, Tarcísio Gurgel dos. Belle Époque na Esquina: o que se passou na República das Letras Potiguar. Natal, RN: Ed. do Autor, 2009.

SCHWARTZ, Jorge. Vanguardas Latino-americanas: polêmicas, manifestos e textos críticos. $2^{\mathrm{a}}$ ed. ver. e ampl. São Paulo: EDUSP, 2008.

Semana de Cultura Nordestina, 1, Natal, 1978. Anais. Natal, Ed. Universitária, 1979.

SILVA, Marcos. (Org.). Câmara Cascudo e os Saberes/ Rio de janeiro: Fundação Miguel de Cervantes, 2013.

Allegro rubato: gêneros textuais e campos de saber em Câmara Cascudo. In:

Câmara Cascudo e os Saberes/ Marcos Silva (org.) Rio de janeiro: Fundação Miguel de Cervantes, 2013, p. 220-233.

Nota Preliminar - "Se Cascudo é o Tema...”. In: Dicionário Crítico Câmara Cascudo. Marcos Silva (org.) 1. ed. São Paulo: Perspectiva: FFLCH/USP: Fapesp; Natal: Ed. da UFRN, Fundação José Augusto, 2003. p. XIII-XIX.

(Org.). Dicionário Crítico Câmara Cascudo. 1. ed. São Paulo: Perspectiva: FFLCH/USP: Fapesp; Natal: Ed. da UFRN, Fundação José Augusto, 2003.

SIQUEIRA, Sônia Aparecida. Superstições no Brasil. In: SILVA, Marcos. (Org.) Dicionário Crítico Câmara Cascudo. São Paulo: Perspectiva, FFLCH/USP, FAPESP; Natal: EDUFRN, Fund. José Augusto, 2003. p. 270-276.

SIRINELLI, Jean-François. “Os Intelectuais”. In. Por uma História Política. René Remond (org.), trad. Dora Rocha. $2^{\text {a }}$ ed. Rio de Janeiro: FGV, 2003, p. 231-269.

SOARES, Gabriela Pellegrino. Diálogos culturais latino-americanos na primeira metade do século XX. In: Projeto História, São Paulo, v. 1, n. 32, p.241-256, jun. 2006. Disponível em:

<http://revistas.pucsp.br/index.php/revph/article/view/2426/1516>. Acesso em: 10 abr. 2014.

SOUSA, Ilza Matias de. Câmara Cascudo: viajante da escrita e do pensamento nômade. Natal, RN: EDUFRN, 2006. 
SOUZA, Auta. Horto, outros poemas e ressonâncias: obras reunidas. Natal, RN: EDUFRN, 2009.

TIN, Emerson. Em Busca do "Lobato das Cartas": a construção da imagem de Monteiro Lobato diante de seus destinatários. Tese de doutorado. Campinas, SP: PPGTHL/IELUNICAMP, 2007a, mímeo.

[et al.]. A escritura epistolar de Câmara Cascudo. In: Vozes e reflexões: Anais do I Encontro Natalense de Escritores. Natal: Fundação Capitania das Artes, 2007b. p. 243-272.

VELOSO, Mariza. Gilberto Freyre e o Horizonte do Modernismo. In: Sociedade e Estado. Brasília: v. 15, n. 2, p. 361-186, 2000.

VELLOSO, Mônica Pimenta. Entre o sonho e vigília: o tema da amizade na escrita modernista. In: Tempo. Niterói, RJ: v. 13, n. 26, p. 205-224, 2009.

VENÂNCIO, Gisele Martins. Da escrita de "bastidores" à mensagem publicada: revistas culturais e correspondências na trajetória editorial de Francisco José de Oliveira Vianna. In: Revista de História Regional 12 (2): 9-28, 2007.

Cartas de Lobato a Vianna: uma memória epistolar silenciada pela história. In: GOMES, Angela de Castro. (Org.) Escrita de si, escrita da história. Rio de Janeiro: Fundação Getúlio Vargas, 2004, p. 111-138.

Presentes de papel: cultura escrita e sociabilidade na correspondência de Oliveira Vianna. In: Estudos Históricos, Rio de Janeiro, nº 28, p. 23-47, 2001.

VEYNE, Paul Marie. Como se escreve a história. Brasília: EDUNB, 1998. 